12-1999

\title{
An Environmental History Of The 19th Century Marquette Iron Range
}

Doug Ottke

How does access to this work benefit you? Let us know!

Follow this and additional works at: https://commons.und.edu/theses

Part of the Psychology Commons

\section{Recommended Citation}

Ottke, Doug, "An Environmental History Of The 19th Century Marquette Iron Range" (1999). Theses and Dissertations. 762.

https://commons.und.edu/theses/762

This Thesis is brought to you for free and open access by the Theses, Dissertations, and Senior Projects at UND Scholarly Commons. It has been accepted for inclusion in Theses and Dissertations by an authorized administrator of UND Scholarly Commons. For more information, please contact und.commons@library.und.edu. 


\title{
AN ENVIRONMENTAL HISTORY OF THE \\ $19^{\mathrm{TH}}$ CENTURY MARQUETTE IRON RANGE
}

\author{
by \\ Doug Ottke \\ Bachelor of Arts, Earlham College, 1994
}

\author{
A Thesis \\ Submitted to the Graduate Faculty \\ of the \\ University of North Dakota \\ in partial fulfillment of the requirements \\ for the degree of \\ Master of Science
}

Grand Forks, North Dakota

December

1999 


\section{PERMISSION}

Title An Environmental History of the $19^{\text {th }}$ Century Marquette Iron Range

Department Geography

Degree Master of Science

In presenting this thesis in partial fulfillment of the requirements for a graduate degree from the University of North Dakota, I agree that the library of the University shall make it freely available for inspection. I further agree that permission for extensive copying for scholarly purposes may be granted by the chairperson of the Geography department or the dean of the Graduate School. It is understood that any copying or publication or other use of this thesis or part thereof for financial gain shall not be allowed without my written permission. It is also understood that due recognition shall be given to me and the University of North Dakota in any scholarly use which may be made of any material in my thesis.

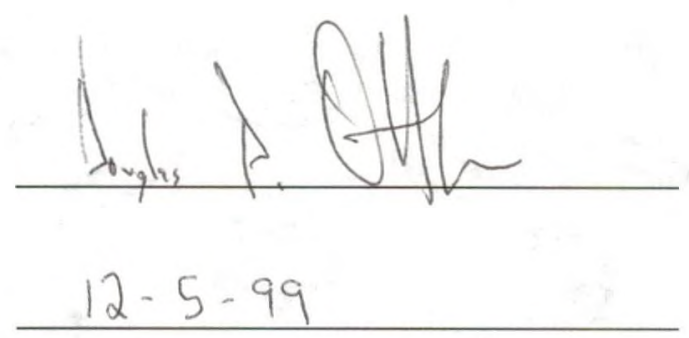


This thesis, submitted by Doug Ottke in partial fulfillment of the requirements for the Degree of Master of Science from the University of North Dakota, has been read by the Faculty Advisory Committee under whom the work has been done and is hereby approved.

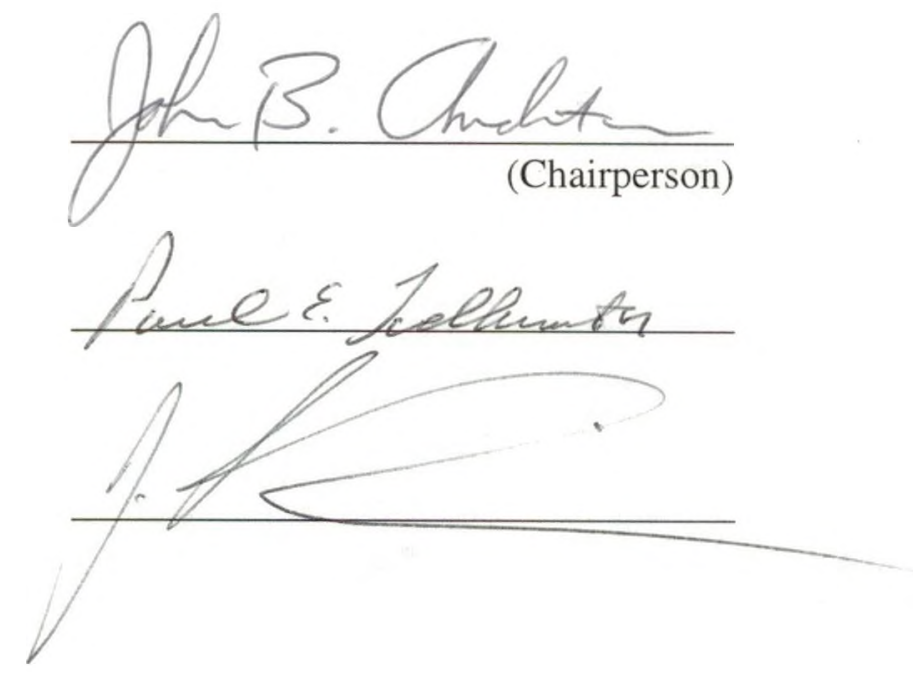

This thesis meets the high standards for appearance, conforms to the style and format requirements of the Graduate School of the University of North Dakota, and is hereby approved.

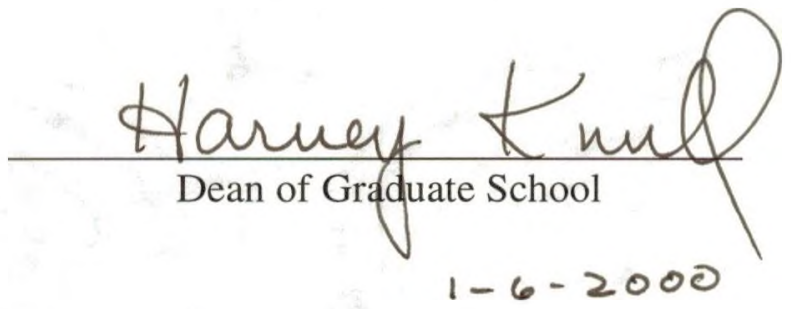

\section{Date}




\section{TABLE OF CONTENTS}

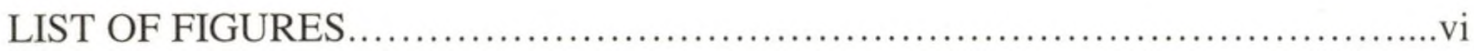

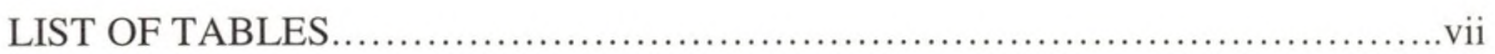

ACKNOWLEDGEMENTS ..................................................... vii

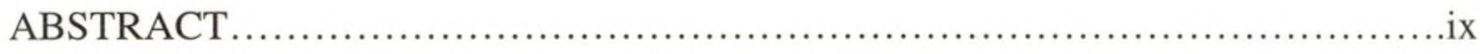

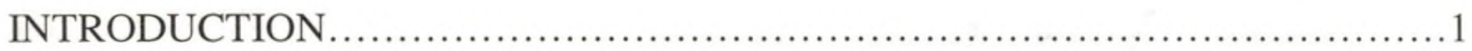

\section{CHAPTER}

I. THE GEOLOGY OF THE LAKE SUPERIOR AREA

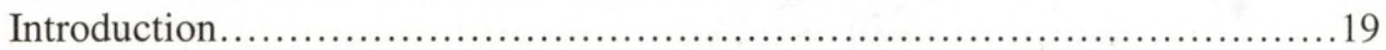

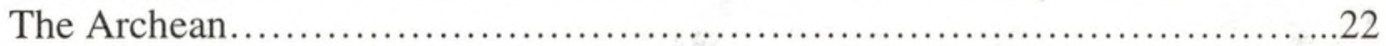

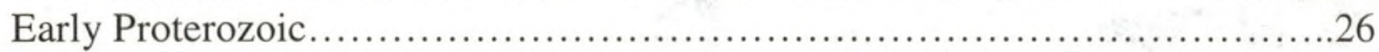

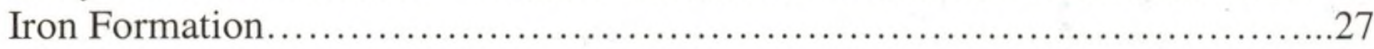

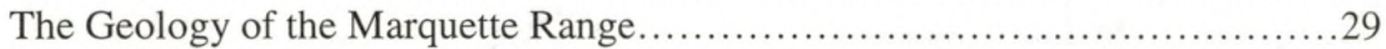

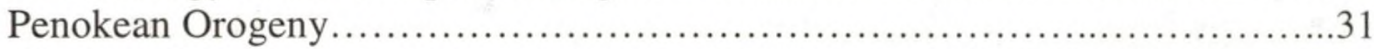

The Middle and Late Proterozoic...............................................

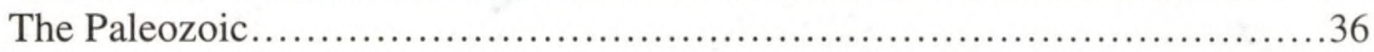

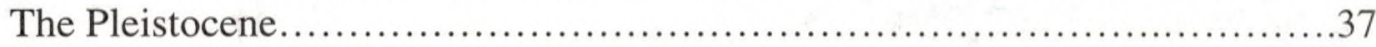

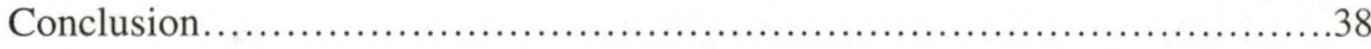

II. THE FOREST OF THE MARQUETTE RANGE

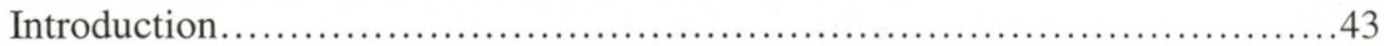

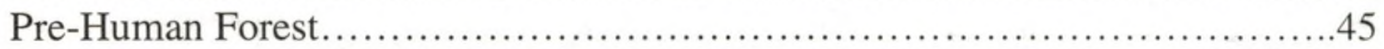

Early Human Impact on the Forest...................................... 47

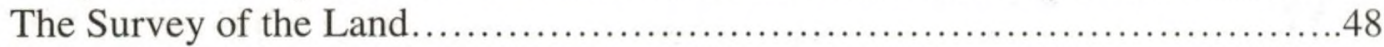

The Logging of White Pine and Hemlock....................................51

Hardwood Logging and Iron Production.....................................5 57

The Kilns of the Marquette Range..........................................59

The Distribution of Sugar Maple and Yellow Birch on the Marquette Range.....61

The Charcoal Bloomeries....................................................62

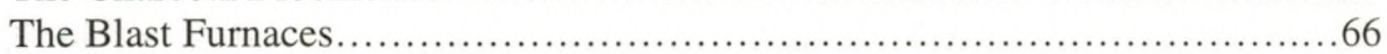

Logging Associated with Shaft Mining...................................6 69

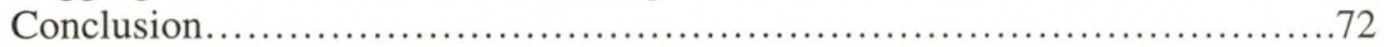




\section{PROPERTY AND LAND USE ON THE MARQUETTE RANGE}

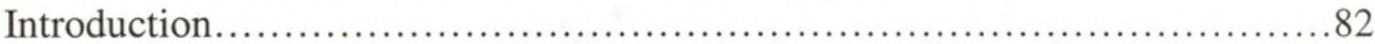

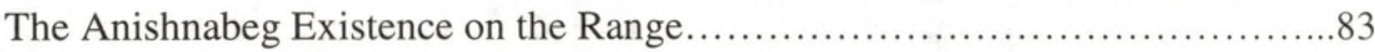

The Anishnabeg View of the Land ......................................... 86

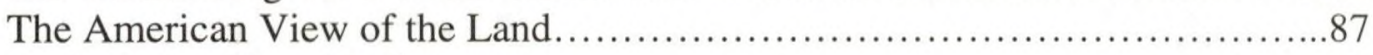

Early Federal Land Policy ............................................... 88

Federal Land Grants and Transportation Improvements on the Marquette

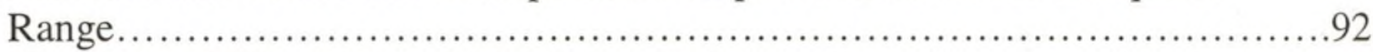

The Federal Dissolution of Aboriginal Title..................................95

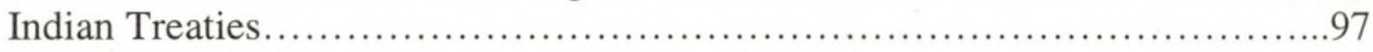

The Treaty of La Pointe..................................................... 99

The Anishnabeg View of the Treaty of La Pointe.............................. 105

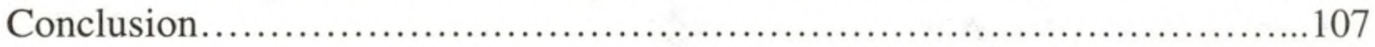

\section{MINING ON THE MARQUETTE RANGE}

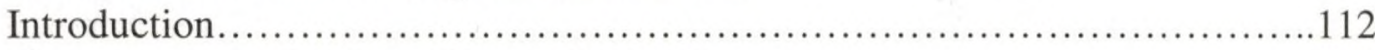

Copper and the Southern Shore of Lake Superior............................115

The Pre-Major Settlement Marquette Range...............................118

The Discovery of Iron Ore............................................. 120

The Geologic Features of the Marquette Range .............................125

The Effect of the Geologic Features on the Mining of the Marquette Range....133

The Open Pit, Surficial Workings.......................................... 137

Early Transportation on the Marquette Range ...............................139

The Underground Workings.......................................... 143

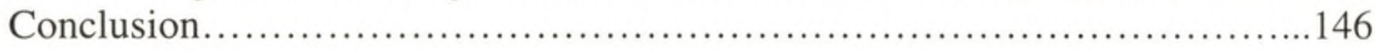

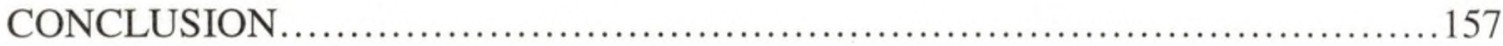

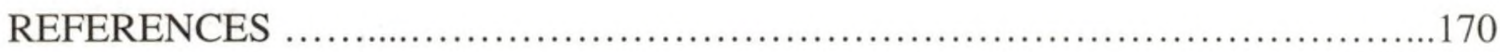




\section{LIST OF FIGURES}

Figure

Page

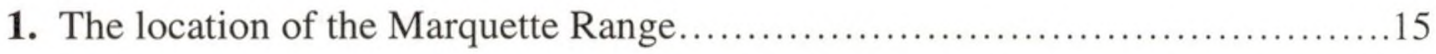

2. Geologic Map of the Penokean Continental Margin.............................23

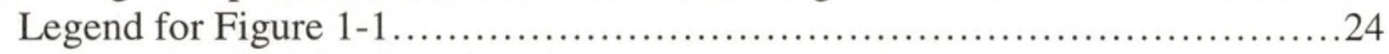

3. Geologic Map of the Marquette Range .......................................30

4. Subterranes and Major Faults of the Penokean Continental Margin Assemblage..33

5. Historic Description of Forest on the Marquette Range From GLO Survey Notes

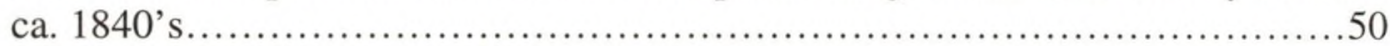

6. Historical Description of the Distribution of White Pine on the Marquette Range From GLO Survey Notes ca. 1840's........................................53

7. Historical Description of the Distribution of Hemlock on the Marquette Range From GLO Survey Notes ca. 1840's.....................................56

8. Historical Description of the Distribution of Sugar Maple on the Marquette Range From GLO Survey Notes ca. 1840's.....................................63

9. Spatial Distribution of Natural and Man-Made Features, Marquette Range, 1868.67

10. Location of the Charcoal Tram Road From the Morgan Furnace to North of the

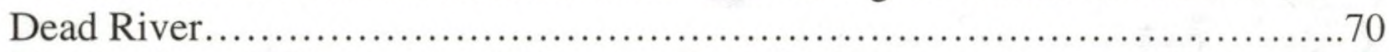

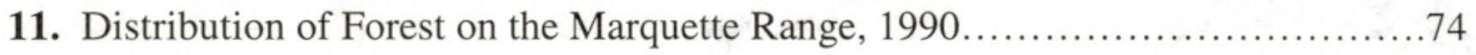

12. Anishnabeg Summer Settlements, ca. $19^{\text {th }}$ Century ........................... 85

13. Distribution of Iron Cliffs Company Land Acquired From the St. Mary's Mineral Land Company Government Land Grant on the Marquette Range in 1865 .......94

14. Cessions of Aboriginal Title By Treaty and Location of Indian Reservations, Upper Peninsula, Michigan.....

15. Location of the Mines, Iron Formation, and Roads on the Marquette Range......126

16. Location of the Mines, Iron Formation, and Roads In the Negaunee/Ishpeming/ Palmer Area.

17. Detail of the 1851 Foster and Whitney Map of the Natural and Cultural Features

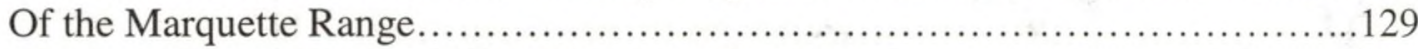

18. Geologic Cross Section of the Marquette Range ................................ 131

19. Distribution of Surface and Underground Workings at the Lake Superior Mine, 1870 . 


\section{LIST OF TABLES}

Table

Page

1. MRDS Records of Mines on the Marquette Range ............................. 149 


\section{ACKNOWLEDGEMENTS}

My advisor, Dr. John Anderton, initiated the idea for this work, and his wide array of knowledge concerning the Marquette Range, and personal support were integral to its completion, and are greatly appreciated. I hope this thesis will be a benefit and an inspiration to his future endeavors in his new position at Northern Michigan University. Dr. Jim Mochurak inspired this writing through his amazing teaching, and his comments on the initial draft were greatly appreciated. Dr. Paul Todhunter found ways to support myself and this research when all the other tenured members of the UND Geography Department felt that neither deserved that support.

Bill Cannon of the USGS has enabled me to better understand the complex and fascinating geology of the Lake Superior area. Rob Barber-Delach, also from the Survey, helped me in every facet of the Geographic Information System projects that are contained in this thesis. Many of the figures present here owe much to him.

The J.M.Longyear Research Library/Marquette County Historical Society and the USGS Library in Reston, Virginia have supplied a very large part of the primary material contained in this work. In particular, Linda K. Panian was very helpful at the Longyear. The purpose of libraries is not to serve information for its own sake, but rather to provide that information to those willing to reach for the truth. Antiquarianism is in no way contained within the agenda of the USGS Library, and only uncommonly encountered at the Longyear.

Martha Herzog, Woody Wallace, and, in particular, Julie Mueller read rough drafts of this work, and their comments have made this a better thesis.

Finally, particular thanks must go to Daryl Hochhalter, Josh Stevenson, Kris Peterson, and Melanie Crow for their friendship, support, and advice. I can not imagine having survived for two years at UND and in Grand Forks without these four people. 


\begin{abstract}
The history of the Marquette Iron Range in the upper peninsula of Michigan is integrally linked to the environment. The natural features of the Marquette Range defined the mode of production on the Range, and conversely, as human systems became more adept in these modes of production they became the most important modifiers of the natural systems.
\end{abstract}

Settlement on the Marquette Iron Range was closely related to two factors of natural environment: the iron ore formations and the hardwood forest. The distribution of three iron ore formations--principally the Negaunee, but also the Bijiki and other Ironformations within the Michigamme Formation --determined the locations of the sites of extraction of iron ore in the area. Stands of hardwood forest, particularly maple and yellow birch were the major factor determining the location for processing operations that converted iron ore into pig iron. The location of beehive kilns where the hardwood was converted into charcoal, the early forges, and the blast furnaces were reliant foremost on the availability of hardwood. The iron ore formations and the hardwood forest of the Range defined the physical subdivision of the land into tracts owned by individuals. Because a readily available workforce was needed at the mines, forges, kilns, and furnaces of the area, locations of settlement on the Range were within very close proximity to the sites of extraction and processing operations. Transportation, from the earliest trails to the plank road, strap railroad and the Iron Mountain Railroad completed in the 1857 were defined by the natural location of the ore and the processes involved with extracting it.

In the mid 1850's, with advances in transportation associated with the completion of the railroad to the mining areas near Negaunee and Ishpeming and the completion of the Sault Locks near Sault Saint Marie, the production of iron ore reached a level of 11,343 tons per year. By 1868 that number had reached a level of 508,000 tons mined. The depression of 1873 caused a sharp drop in production. However, for the year before 
the drop one million tons had been withdrawn from 40 pits carved into the ore bodies. In 1880 two million tons were mined and that number rose to seven million tons mined during the year of 1890 . The quarrying operations progressed deeper into the earth until by the 1880's shaft mining became a necessity, calling for advancement in technological applications and forcing many of the less wealthy operations out of business. The large amounts of capital involved in diamond drilling exploration, and the operations underground forced industrial consolidation of the many small operations into a few large companies commanding large resources. As mines went underground, the need for timber also increased as supports for the underground workings became a necessity. Between .72 and .92 cubic feet of timber was needed per ton of ore extracted.

In 1868 eleven blast furnaces were in operation on the Marquette Range. Twenty five furnaces total were built in Marquette County. Numerous beehive kilns dotted the countryside. These kilns converted maple, yellow birch and, in some instances, hemlock, pine, and other softwoods into charcoal. The charcoal consumed per ton of iron produced in furnaces varied from 110 bushels to 140 bushels, with a bushel consisting of 20 pounds of charcoal. The Pioneer Furnace, the original blast furnace in the area located in Negaunee, used the timber from 1,500 acres in the year of 1869 to produce 9,500 tons of pig iron. One acre of wood could produce 14 tons of iron. It is estimated that by 1903 thirty acres of hardwood per day was needed to supply the kilns of the Marquette Range. In the first half century of iron production 330,000 acres were cut.

In order to understand more thoroughly how natural and human systems have modified each other on the Marquette Range, the pre-major European settlement natural environment must be delineated. Beginning in 1838, the Michigan Geological Survey and the Linear Survey of the U.S. Land Office created descriptions of the natural environment of the Marquette Range. These descriptions better enable the understanding of the pre-major settlement natural environment. The descriptions contained within these reports of the location of the original outcrops of iron ore and the stands of trees shows how important these factors were to the early settlement of the Marquette Range. The descriptions also allow us to see how influential that settlement was in modifying the natural systems of the Range. 
He was tired, and his mind worked at random. His eyes kept to the bright thread of water before them. The path it found to make its way to lower ground was as coiled as a hog's bowel. He had learned enough of books to think that gravity in its ideal form was supposed to work in straight lines of force. But looking on the creek as it made its snaky way down the hill, he saw such notions to be just airy thoughts. The creek's turnings marked how all that moves must shape itself to the maze of actual landscape, no matter what its preferences might be.

-Charles Frazier in Cold Mountain 


\section{INTRODUCTION}

Early in May of 1999, I took a flight from Reagan National Airport in the flat and wide Potomac River Valley of Washington D.C., just south of the Mall, to Marquette in the Upper Peninsula of Michigan. Taking off in a northward direction from the short runaway at Reagan National, it took only seconds for the plane to lift up over the geometrically shaped green clearings and large, sharply white monuments of the district, the plane rising above the blue water of the Tidal Basin. We passed directly over the Lincoln Memorial; the long straight clearing of the Mall leading past the Washington Monument to the Capitol Building distinct on its hill off to the right. On the left of the plane the very large building of the Pentagon and Arlington National Cemetery with its evenly placed white headstones dominated what I could see of Virginia. Curving gently around the high-rises of Arlington, the body of the plane rotating, lifting its right wing, we turned westward, traveling above the lower portions of Georgetown with the gentle rises of the northwest part of the District in view, the National Cathedral present at the top of one of those rises, the area framed on one side by the Potomac and the other by the trees of the Rock Creek Parkway curving down to the river. We traveled northwest generally following the flow of the Potomac and rose above the clouds just as the subdivisions of western Virginia and central Maryland began to turn into more sparsely developed farmland.

The nose of the plane was still pointed upward, the flight attendants pushing the beverage carts on the incline, as the plane passed above the Appalachian Mountains. The clouds obscured much of the transition from the light olive drab and tan parcels separated by dark green copses of trees of the small farms of Maryland and Virginia to the linear ridges of the Valley and Ridge province of West Virginia and Eastern Pennsylvania. We passed Pittsburgh to our left and as we flew over northeastern Ohio, only barely had the flight leveled out, the clouds slowly clearing to expose, through haze, flat terrain containing precisely plowed fields. Lake Erie soon came into view with the outskirts of 
Cleveland becoming more dense within the view on the right side of the plane. Flying south of downtown Cleveland, the Key Bank building and the large and recently built baseball and football stadiums dominated our distant view. From many miles away and 35,000 feet in the air the iron ore carrier, William Gwinn Mather, was barely visible at its now permanent location near the pyramidal, vitrescent design of architect I.M. Pei serving as the Rock and Roll Hall of Fame.

Lake Erie, brown, cold and dull in my memory, forming the northerly horizon from the shores of northern Ohio, now, from the great height of the aircraft, was an incredibly luminescent blue, slender and beautifully formed. Canada seemed so near to Ohio, the very flat and angular Island and point of Pelee almost, it seemed, within swimming distance from Kelleys and the Bass Islands.

Before I could begin to grasp the true distance, and acclimate myself to the great height of my perspective, analyzing a familiar geography, we began our approach to Detroit Metropolitan Wayne County Airport, the airline engines changing their tone as the airplane started to slowly drift downward. Gliding toward the airport, we passed over several large ships appearing stationary but heading northward in the water of the Detroit River, between Grosse Ile and Fighting Island.

As I sat in the airport in Detroit, having lunch with my boss from the Geological Survey and trying to read, I considered the rest of my trip to Marquette, and thought of how it differed from other trips I had read of. In late May of 1840, 159 years before my plane trip, an expedition led by Douglass Houghton embarked from Detroit headed to the Upper Peninsula of Michigan. Detroit at that time was the capital of the three year old state of Michigan, and had a population of just over 8,000 people. Houghton's expedition was a geological and biological survey of the remote lands of the more northerly peninsula of the young state, an area with only a handful of settlements and a EuropeanAmerican population of just over 1000. Their trip was an arduous and adventuresome undertaking, and took an entire summer to complete. Leaving May $21^{\text {st }}$ of 1840 , the men traveled by the steamboat Illinois northward 320 miles to Mackinac Island. The steamboat left Detroit at 10 o'clock on a Thursday morning, and without stopping, in clear weather and smooth water, arrived at Mackinac at 7:00 on Friday evening. At this 
point in their trip, the men employed light boats constructed of pine and cedar, 20 feet long by four feet broad with pointed bows, to travel to Sault Ste. Marie. The boats were propelled by oar, Canadians and Indians doing the rowing. It took the boats a better part of a week to reach the Sault. After portaging the rapids there, the expedition continued along the south shore of Lake Superior stopping frequently to gather data of the remote and beautiful land. They arrived at the area of the Marquette Range on June $15^{\text {th }}, 24$ days after they left Detroit.

A few years later, in July of 1845, another expedition, consisting of Philo Everette, S.T. Carr, Edward Rockwell, and W.H. Munroe embarked on the journey to the Keweenaw Peninsula, from Jackson, Michigan in search of mineral wealth. The journey was equally as arduous as Houghton's and required that the men spend three weeks en route. These men, who were part of the Jackson Mining Company, the first company to extract and smelt iron from the Marquette Range, followed a circuitous and extended route through the wild country of the lower peninsula of Michigan and then on the waters of the Great Lakes. From Jackson to Marshall, Michigan the men who went to the Upper Peninsula in search not of iron, but rather copper, spurred on by the first mineral rush in the history of the United States, took a strap-rail steam road. From Battle Creek to Grand Rapids they traveled by stage coach and then northward, for four days, to the Straits of Mackinac by tote wagon, hard boards laid across the bed for seats. At the northernmost point of the lower peninsula, within view of the Upper Peninsula, their journey by boat began with a short canoe ride, Indians for paddlers, to the island of Mackinac. At Mackinac Island the expedition caught a steam powered boat, the S.S.General Scott, travelling around St. Vital Point along the Saint Mary's River to Sault Ste. Marie and the rapids there that separated Lake Superior from the lower lakes Great Lakes. At the Sault, the men purchased a 40 foot white cedar Mackinaw boat from Indians for 45 dollars and paid another ten dollars to have the boat portaged around the rapids and placed on the waters of Lake Superior. At Sault Ste. Marie the men learned of mineral wealth near Carp River on the Marquette Range from an Indian, and hired him as a guide to lead them through Whitefish Bay, along the northern coast of the Upper Peninsula, past Grand 
Island and to the Range. They finally arrived in the area three weeks after they left Detroit.

My trip from Detroit to Marquette in a Saab twin engine was radically different from those that occurred so long ago, taking a little over an hour. The small plane took off from Detroit and rose quickly to an elevation of 10,000 feet above the agricultural land of the central Michigan Basin. As the plane headed northwest, forests became more plentiful and the terrain, very flat in the center of the state, became more rolling, with drumlins and morains of glaciation present. Twenty-five minutes into the flight the breathtaking view of Grand Traverse bay opened up to the right of the plane, the main body of the bay in the north splitting up into east and west arms farther south. The irregular, elongated, bizarre and forested peninsula extending between the two arms ended at Old Mission Point far to the north. The very blue appearance of the water of Grand Traverse Bay revealed, through its extreme clarity, sand bars of near shore lacustrine deposition beneath the water; from the great height they seemed like wisps of bizarre, surreal brushstrokes on a grand scale. With Cat Head Point to the right of the plane and the extensive Sleeping Bear Dunes to the left we began our flight over Lake Michigan, passing north of the Manitou Islands; Beaver Island off to the northeast. Peering down through the occasional clouds once we were out over the lake, I could see, even from the great height, breaking waves on the water's surface nearly two miles below.

Across the lake the plane reached the southern coast of the Upper Peninsula. Toward the southwest Summer, Poverty, St. Martin and Rock Islands led to the larger Washington Island and the beginning of a large peninsula extending a vast distance on the southern side of Green Bay. We flew over the Garden Peninsula, with Big Bay de Noc and then Little Bay de Noc coming into view and the port towns of Escanaba and Gladstone curling around the second inlet. We flew over the land of the Upper Peninsula and at the fast pace, the plane spent only minutes in the air over that broad expanse of land. The glimpses I received of the Upper Peninsula from the air were very brief, yet even with the brevity, the views revealed much more than my memory could take note of, 
and the perspective left an important impression upon my understanding of a region I have studied over several years.

Heading toward the Marquette airport, the closer we came to the Range, the more I wondered how I could devise a scheme to convince the pilots to make one or two passes over the area, allowing me to see the Range for a longer time from this new and intriguing perspective. No such scheme revealed itself to me, and with the plane descending on a direct route toward Marquette, still some 50 miles away, the landscape of the Upper Peninsula passed quickly far below; its rivers, forests, and geology augmented by roads, clearings and exiguous settlements. The brown, leafless hardwood forests and occasional patches of conifers, dry from an extended spring drought, dominated the flat terrain. The land appeared very dry. Where I imagined there should have been wetlands and lakes, there was only sandy forested land, occasionally partitioned in geometrical flat parcels. Unpaved roads, revealing bright sand, alternated with paved roads running very straight through sparse habitation. Property boundaries were noticeable in very straight lines of transition between cut-over and second growth forest, the cut-over exposing a light brown sand turned by the displaced trunks and logging two-tracks. Only occasionally was a community of more than a few houses sustained, and from the great height it was possible to imagine the land as it must have looked during the early $19^{\text {th }}$ century, free of major settlement, with sparse tracks, and quiet.

For several months before I embarked on my plane journey to the Marquette Range, I worked in Reston, Virginia, a suburb of Washington D.C., employed at the U.S. Geological Survey, performing computer cartography. This work consisted, almost exclusively, of the construction of a geologic map, and an associated relational database for that map, of the Penokean Continental Margin of the Upper Peninsula of Michigan and northern Wisconsin. During many hours of constructing the map, staring blurry eyed at a computer screen, I noted the remarkable transition between the flat-lying, undeformed sedimentary rocks of the eastern Upper Peninsula, and the much older, extraordinarily complex and deformed Precambrian rocks of the western Upper 
Peninsula. The transition between these two geologic terrains on my digital map, a line curving greatly on a small scale but trending in a north-south direction on the full view, just to the west of Escanaba, running out into Lake Superior just east of the Marquette Range, was a striking contrast between a uniform grayish brown on the right and a melange of colors to the left. The uniform grayish brown to the right represented Paleozoic sediments, and though the rocks were simplified and undifferentiated on my map, the representation was still accurate: the geologic formations were flat-lying and simple. The left side of the map was quite different and could never have been described as simple. It presented many pinks, greens, blues, and reds, intricately interwoven in a tapestry of beautifully surreal, natural curves, truncated by linear faults and crossed by numerous intrusive igneous dikes, sills, and plutons. The contrast between the two was striking, and quite apparent with even a cursory glance.

What had occurred, beginning 600 million years ago, to account for this profound difference in shape and color on my spatial representation of the area, was that the sea had encroached upon a land scarred through many million years of tectonic deformation. The intricately deformed terrain in the west was slowly and quietly covered by transgressing water, and upon the retreat of the sea, sediments were left behind which would eventually become the simple, undeformed, flat lying gray colors of the right side of my computer screen: the Paleozoic sedimentary strata of the eastern Upper Peninsula. Viewed abstractly, the boundary separating the two areas could be considered a very old shoreline, running west of Escanaba to the high ground of the Marquette Range, the inlets, bays, peninsulas, and points evident in the curvature of the boundary.

As the plane flew northward along this corridor, the 300 million year old shoreline to the left, I ignored the seatbelt requirement notifications and, filled with anticipation, moved to the opposite side of the plane, prepared to gaze down at that remarkable line of demarcation between two radically different bedrocks. Peering out the window, I expected the boundary to be apparent, the flat lying terrain of the east giving way to deeply incised valleys, exposing dark colored knobs and ledges of ancient metamorphic Proterozoic metastrata. I expected to see the complexity of the basement material revealed in the surface patterns of the land. However, my expectations proved to 
be naïve, and as I strained my eyes for some sign of the transition, I saw only the same unending second growth of hard and softwoods, the same flat, dry, and scantily populated forest. Only an increase in the number of lakes hinted at the change. The transition, quite evident to a geologist hammering away at outcrops on the surface, was from a great height nearly imperceptible, the geologic differences not shown and the topographical variance insignificant.

Drawing ever closer to my field study area, several aspects of the resource extractive landscape of the range came into view. Passing over the extensive but now unused landing strips of closed K.I. Sawyer Airforce base, the present day iron mining of Range showed itself in the very spatially extensive, bright maroon, almost pink colored tailing ponds of the Empire and Tilden mines. The tailing ponds were large, flat impoundments of slurry refuse from the processing operations of these two open pit taconite mines; the only two iron mines still in operation on the Range. Just beyond the flat, bright colored fields of slurry, expanding outward and swallowing up lakes and forests, were the mines, very dark gray and reddish colored holes taking up entire sections of the land and revealing for the first time the ancient and complex rocks south of the towns of Negaunee and Ishpeming. Large buildings for the processing of the ore existed near the edge of the pits and very large piles, almost mountains, of waste rock, also very dark in color, framed the entire operation. The mountains of tailings, material removed from the earth but too low grade to be used in the processing operations, surrounded the pits, with the alluvial fans of the tailings basins, material discarded from the processing operation, spreading southward.

Toward the west where the mining operations now dominated the landscape, the first large scale settlement since Escanaba, that of Negaunee and Ishpeming, showed orderly streets and bounded lots. A closer look at the two towns, set just north of the mining operations amongst hills of metadiabase, revealed large buildings and head frames associated with the iron mining of the area; mining dating back over 150 years. The hills of the area, gently rising and more noticeable as we flew directly over the Precambrian terrain, were wooded with leafless hardwoods occasionally augmented by stands of conifers. Between the wooded hills, very familiar shapes of some of the 
prominent lakes of the Marquette Range, so often viewed by myself on maps of the Range, now traveled beneath the plane, verifying in reality their distinctive forms. We passed over the aptly named Goose Lake, shaped abstractly like its moniker, the head of the goose pointed southeast, with an embankment for the tracks of the peninsular railroad cleaving off part of the lake as it traveled south toward Escanaba. The distinct forms of Teal Lake, just north of Negaunee, and the reservoir Deer Lake north of Ishpeming also were quite recognizable.

Far off to the west, on the horizon which limited my view from the plane, a large plume of smoke rose into the air. The plume was the result of a major forest fire in the Upper Peninsula, which occurred south of Lake Michigamme on the far western part of the Marquette Range, and burned 5,600 acres. The wildfire, driven by strong winds, spread swiftly through the dry mostly cut-over property and only let up with the rain that came a few days after our arrival. During a much earlier period fires such as this were a common destructive force on the Range. Started often through carelessness and by hot cinders from the early locomotives of the area, the fires burned quickly through the underbrush left behind by major logging.

We began our landing at the Marquette County Airport just east of the town of Negaunee. As we descended, the precipitousness of the terrain became more apparent and as the plane turned westward to land on the runway I was able to view the southern part of the Marquette Syncline, the ski resort on one of the hills of the synclinal edge still with patches of snow on its runs. The hilly landscape of the Range made itself even more apparent as the plane was bounced and jostled by thermal pockets, combining with the brisk wind to make for an exciting landing in our small plane; we had arrived on Marquette Range.

The geologic map which I spent so much of my time staring at in the John Wesley Powell, United States Geological Survey building in Reston, Virginia before I flew to the Marquette Range in early May of 1999 represents the first place a student of history should go for understanding concerning the Marquette Range. Contained within its many colors and abstract shapes, its representation of the spatial distribution of the bedrock 
geology of the area is the framework and context of all of the history and distribution of ecological and human systems on the Range. The relationship between the geological and human systems was not always direct, but iron was the fundamental factor in the history of the Marquette Range, so that the location and distribution of the bedrock containing iron, the iron-formation of the Range, was always important to the human systems. Staring at the complex geological map on the computer screen, overlying the geology with roads, towns and boundaries of the land, I could vividly perceive the interrelationship between the natural and human worlds; an interrelationship where the rocks have defined and modified human agency and settlement, as, at the same time, humans modified the geology by stripping its iron rich rocks, then delving beneath the surface to continue the removal. I was able to perceive how closely associated geology and human history are within a resource extractive economy, and I realized that to understand the geologic map in front of me was to begin to understand the human history of the Marquette Range.

Expanding the view of the area beyond the Marquette Range to incorporate the entire Penokean Continental Margin, it was possible to see that the geology determined settlement patterns throughout most of the western Upper Peninsula of Michigan and northern Wisconsin. Where iron formation was found (marked in a bright red on a map that extended roughly from Marquette, Michigan in the east to Ashland, Wisconsin in the west, in a swath approximately 100 miles wide) could also be found the major population centers. The towns of Negaunee and Ishpeming on the Marquette Range, Iron River, Crystal Falls, and Iron Mountain on the Menominee Range, and Wakefield, Bessemer, Ironwood, and Hurley on the Gogebic were all determined by the distribution of the iron bearing rocks. The exceptions to this rule, the towns of Marquette, Ashland, and Escanaba, were towns that began in large part because they were transportation centers for the iron ore; their location was linked to the harbors that served the Great Lakes shipment of the ore.

Because of its intimate attachment to the geology of the area, the history of the Marquette Range is a history that is incredibly ancient. The rocks that would eventually have such a profound effect upon the distribution of the population of the Lake Superior 
area, that would define in many respects the lives of the people who would settle the area, came into existence four billion years ago. While the Earth was still young, volcanic activity, and erosion ceaselessly wearing away at the rocks formed by this volcanic activity, left behind the bedrock that would make up the surface of the Lake Superior area. These incredibly old rocks, exposed to many episodes of deformation throughout their long existence, make up a record of the Earth's history that is exceedingly complex and difficult to understand. Over several billion years, the tectonic collision of terranes that added to the size of North America left their mark on the rocks of the Range, the crust buckling under the applied pressure of the collisions, and at other times ripping itself apart from magma rising to the surface. Each mountain building episode further reworked the melange of terranes, adding further to the complexity. Alternating with these tectonically active periods were quiescent episodes where the sea washed over the land and gently deposited sediment that would eventually lithify to form thick layers of sandstone, limestone, and the iron rich rocks that would have such an important role in the human history. A billion years ago, all tectonic activity halted and the area became stable. Erosion was always active, the sea continued to encroach upon the land, and glaciers invaded the area. All of these activities left behind their mark, and added further to defining the history of the region.

In conjunction with the geology, the biology of the area played a vital role in the history of the Marquette Range. The stands of trees augmented the effects iron production had on human settlement and economic production. As the forests effected human systems, it was profoundly altered by those human systems which clear cut the valuable economic commodities. After the last major glacial advance over the land of the Marquette Range, the species of trees that would make up the distribution of the forests of the area slowly migrated from the south. The migration of these arriving species, occurring between 10,000 and 3,000 years ago, took many years to accomplish, with the local distribution of the plants affected by the order of their arrival to the area, as well as the distribution of soils in the area. Several thousand years before humans would settle in large numbers on the Marquette Range the natural matrix of trees that would greatly affect that society was established. This matrix consisted of, but was not limited to large 
stands of sugar maple and yellow birch, augmented by hemlock, white pine and cedar. Although some influence from the aboriginal peoples occurred with the introduction of set fires, before the large scale settlement of the Range, which began in the mid- $19^{\text {th }}$ century, natural disturbance caused by fire, wind, flooding, insect infestation, and disease was the main factor disturbing the growth of the trees in the area. With only this limited disturbance, the forests flourished, maturing and growing large trees. It was these large trees that would influence the human systems and history on the Range.

After billions of years of history on the Marquette Range, the human history of the region began with the initial settlement by aboriginal peoples following Wisconsinan Glaciation, roughly 10,000 years ago. For centuries the Anishnabeg Indian tribe lived in scattered bands throughout the area, existing on the fishing, hunting and gathering of naturally provided commodities. Beginning in the $19^{\text {th }}$ century, large scale settlement of the area occurred, with European-American settlers arriving in large numbers. The transition from the small numbers of Indians in the area to large scale settlement of the area by European-Americans witnessed the transition from a subsistence based economy to a capitalist economic system where certain select natural commodities on the Range were linked to commercial markets. The market economy led a resultant radical change to the land. The scale of the resource extraction of these two societies was radically different, as the basic philosophies behind the extraction were different.

The transformation of the land of the Marquette Range that occurred with the large scale settlement of the land by European-Americans in the mid- $19^{\text {th }}$ century came about in large part through the transfer of the land into individual holdings. With the coming of capitalist society, land that had existed for its own sake, not as a commodity the only purpose of which was to maximize economic yield, was transferred into the holdings of individuals, bounded and then systematically manipulated for profit. This process occurred through the government's purchase of the land from the Anishnabeg through the Treaty of La Pointe in 1842. After the transfer of the title from the Indians to the government, the land was surveyed, and then sold to individual interests.

What those who acquired the land of the Marquette Range chose to do with their properties had everything to do with a desire to increase capital. Every valuable natural 
commodity within the bounded landscape was manipulated at the highest level economically possible. Though limited greatly by a remote setting, primitive methods of transportation, and a small workforce, the first miners and loggers on the Range extracted as much of the natural commodities as could turn a profit. Through the $19^{\text {th }}$ century the market demand for iron and timber increased, and as transportation improved and methods of extraction were honed, the manipulation of the environment also became more acute. Individual profit was realized through the destruction of the natural environment determined by a market, with this system lasting throughout the $19^{\text {th }}$ century to the present day.

Descriptions of the natural environment of the Marquette Range, dating from the first expeditions to the area, detail an amazing natural landscape containing immense stands of timber and massive deposits of iron ore. From these large and valuable resources a society carved out an existence on the Range, and in doing so changed forever the natural environment. Large, exposed outcrops of iron ore, anomalous deposits of banded, laminated, specular, jaspery hematite drew the first settlers to the region and were the reason for the first land claims. These outcrops were the first resources to be extracted from the area, and signified the first significant inroad of civilization on the Range. In quick succession, logging of white pine and hemlock for building materials, and hardwoods for the primitive smelting of the ore began in the area. The logging of the valuable white pine stands led to the construction of several sawmills on the Range. This valuable timber was quickly exhausted, and several rivers in the area were altered in order to transfer the pine from its origin to the processing facilities. Conditioned by the iron making philosophies of the early $19^{\text {th }}$ century, and aware of the amazing combination of timber and iron resources on the Range, the initial settlers believed that, in addition to an iron mining region, the area could also be an iron production center. This belief led to first forges and then a great number furnaces to be built in the area. These smelting structures were supplied with the large amounts of charcoal that was needed to smelt iron ore into pig iron by hundreds of charcoal kilns dotting the country side, located wherever there were stands of hardwoods. The hardwoods that were chiefly used in this smelting process were sugar maple and yellow 
birch, and the large demand for these trees brought about their removal at a large scale. The furnaces of the district reached out further and further for the timber, clear cutting swaths that grew larger each year.

The mining of the iron that was processed in the forges and furnaces of the Range was determined by the distribution and nature of the ore present. Two types of ore were found in abundant supply within the complex rocks of the Range: hard and soft ores, and the natural distribution of these ores determined the nature of the mining and the success of the mines on the Range. The hard, resistant ore was found near the surface of the district and was the first type of ore to be mined from the Range. The ore was first cleared of its overburden, then blasted out of place, with the blasted pieces then broken up and loaded into carts for transportation. The early mining actives, similar to a quarrying operation, were possible because of the abundant supply of surface ore and relative ease of extraction. This allowed numerous companies to mine the ore of the Range at a profit. The second type of ore mined in quantity on the Range was a soft ore that was mostly found deep beneath the surface. The surface deposits were extensive, however as they reached exhaustion beginning in the 1870's mines continued their operations by reaching for the ore beneath the surface. Underground mining was an expensive and dangerous activity and systematic, detailed planning of shafts and drifts beneath the surface to get at the underground ore was necessary. The workings in the soft ore mandated extensive supporting structures such as rock pillars left in place and not mined or timber frames, which necessitated the cutting of large amounts of timber, further adding to the demand on the natural systems.

Capital consolidation occurred in the Marquette Iron Range mining business toward the end of the $19^{\text {th }}$ century. At one point in the 1870 's, over 50 independent companies were removing ore from the Range. However, by 1900 this number had dwindled down to only a handful of large companies, with extensive holdings. The reasons for this consolidation came from the natural environment. The nature of the ore and the forests determined the economical viability of individual companies extracting these resources. 
Figure 1 shows the location of the study area for this project. Somewhat of a misleading name, the Marquette Range refers less to a particular linear stretch of topographically high ground than it does to the Marquette Synclinorium. This structural feature does outcrop in a pair of generally parallel linear hills, however it is an exaggeration to say that the edges of the synclinal structure constitute a mountain range. Much of the country north and south of the area, though geologically very different, is similar both in elevation and appearance to the Range proper: hilly, wooded country with lakes present in the low ground between the ridges. My particular area of interest has been an area extending from the city of Marquette in the east to Lake Michigamme in the west, and from the Dead River in the north past the Republic Trough and the slurry pits of the present mining in the south. Expressed in latitude and longitude the area extends from -87 degrees, 20 minutes in the east to -88 degrees, 10 minutes in the west and from 46 degrees, 36 minutes in the north to 46 degrees 20 minutes in the south. I have remained as consistent as possible using this area in most of the maps of the work. It does not include all of the mines and forests relevant to the history of the Range, however, it contains a majority.

The purpose of this thesis is to better understand the relationship between nature and capitalism that has existed in the past and currently exists in the world today. I have attempted to better understand resource extractive economies by concentrating on one particular spot, and what happened in this spot during a period beginning in the early $19^{\text {th }}$ century and lasting until the end of that century. In some ways, the choice of the Marquette Range has been ideal. Very little human disturbance occurred on the Range prior to the beginning of the resource extractive economy, and excepting mining and logging, no other industry played a large role there until the $20^{\text {th }}$ century. Several very thoughtful and thorough accounts of the area prior to major settlement were written and were available, and I was able to access many accounts of the mining and its relation to the rocks of the Range. The relatively simplistic nature of the two resource economy was important to my generalized, microcosmic approach. 


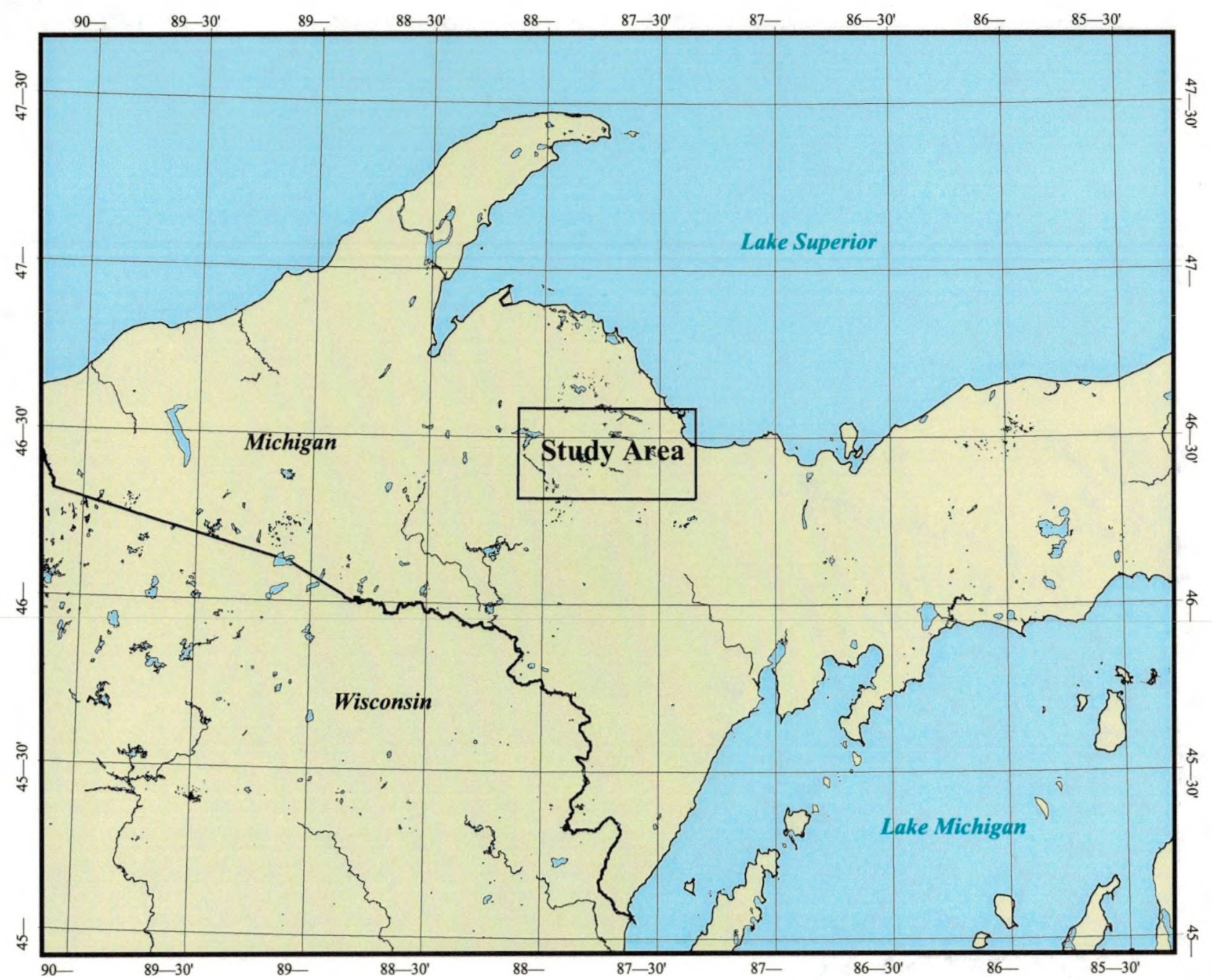

Figure 1. The Location of the Marquette Range 
To better understand the change that the application of capitalist society wrought upon the natural order of the Marquette Range, while also trying to understand the influence that the natural order had on capitalism, it is essential to understand what the area was like prior to major settlement. This has been accomplished through the analysis of accounts from the initial expeditions to the area, the first surveys of the land, and the first settlers to the area. The descriptions of the mines, their close tie to the location and nature of the ore and their affect on the natural environment has come mostly from geological reports, as has the descriptions of the forests and logging in the area. Maps are an essential part of this work.

The picture that I arrive at, of what the land was like before our society altered it wholly, is an incomplete picture. I have only received general snapshots of a world which will never exist again. Each individual view of the environment was conditioned by the personal bias contained within the individual viewers, just as my synthesis of those views must in some way be biased. However, it is essential to always believe that the truth is knowable; this thesis will add to the truth of the history of the Marquette Range. Our knowledge of that truth, or a better view of it at least, will help us to better understand American Capitalism, and will in this sense set up a counter hegemony which we can employ to definite, achievable purposes.

Although I have quantified the alteration of the natural environment as best I could, this too is, in many ways, incomplete. Looking at a complex natural system that existed 150 years ago through only historical works can only be an incomplete endeavor. Even less clear is the effect the natural features have had on the society, for though I believe that we, as a collective, do things for reasons, and these reasons can be known and charted, individuals within this collective act through their own volition and human agency undermines broad generalizations.

This thesis covers a wide array of topics within its limited space. Geology and biology, anthropology and history all fit into this work of geography. I have outlined the major influences on the history of the Range by analyzing the interplay between nature and society. The result is this environmental history of the $19^{\text {th }}$ century Marquette Range, 
and a beginning into the understanding of the relationship between a planet and its most powerful resident. 


\section{END NOTES}

${ }^{1}$ Carter, James L. and Rankin, Ernest H. (editors). 1970. North to Lake Superior, The Journal of Charles W. Penny, 1840 The John M. Longyear Research Library, Marquette MI. p. xxi

${ }^{2}$ Ibid., p.1-28

${ }^{3}$ Hatcher, Harlan 1950. A Century of Men and Iron Bobbs-Merrill, Indianapolis p.33

${ }^{4}$ The Mining Journal for Thursday, May 6, 1999

${ }^{5}$ This figure was constructed in Arc-View from an ESRI Data and Maps CD showing detailed maps of the United States. 


\section{CHAPTER I. THE GEOLOGY OF THE LAKE SUPERIOR AREA}

Introduction/The Archean/Early Proterozoic/

The Iron Formation/The Geology of the Marquette Range/

Penokean Orogeny/The Middle and Late Proterozoic/

The Paleozoic/The Pleistocene/Conclusion

\section{Introduction}

The rocks of the Lake Superior area, ancient and complex, record in their makeup and configuration over three billion years of the Earth's history. Over this incredibly long period of time, the rocks of the Upper Peninsula of Michigan, Northern Wisconsin and Northeastern Minnesota have undergone numerous and profound changes, recording the collision and divergence of the continents, volcanism and metamorphism, and episodes of deposition and erosion. They record so much history that to study them is to study how the Earth itself, its atmosphere, oceans and life, formed and have evolved to the present. Clear perspective regarding such large amounts of time is difficult from a temporal human viewpoint. To clearly comprehend the vast amount of time that the forces of the Earth have worked on these rocks, to understand the true history of the area, is to intensify a sense of human transience.

In the beginning, four and a half billion years ago, the Earth slowly began to heat up through the decay of radioactive elements in its interior. This heat transformed the Earth from a lifeless inert conglomeration of comets and other space debris into a dynamic and active body. The heat became great enough over time to melt the rocks of the interior, and as more of the Earth became molten, iron and nickel, present from the bombardment of the earth's surface by meteorites, sank to the center of the earth to form its core. At this same time, lighter weight materials in the form of magma migrated to the surface of the Earth, erupting continually to form a basaltic crust. This crust was separated from the dense interior by a partially molten mantle consisting mostly of magnesium-rich peridotite. By four billion years ago, the differentiation of the Earth into 
core, mantle and crust had occurred. With this extraordinary movement of material and volcanic activity was associated the release of enormous quantities of gas and steam, which formed the Earth's original, primordial atmosphere, with water vapor in this atmosphere condensing and falling to the surface to begin the slow, inexorable erosion and redistribution of the Earth's surface material. This initial precipitation began to erode the volcanic terranes of the young Earth and spread out into the depressions of the surface forming the first oceans. ${ }^{1}$

Four billion years ago the part of the Earth's surface that would eventually become the Lake Superior region was a large body of ocean containing several chains of volcanic islands. The islands had been constructed gradually through thousands of successive volcanic eruptions, over millions of years, building the seafloor up to the water's surface. As this volcanic material broke the surface of the water, it was eroded and redeposited back on the seafloor and this deposition, through lithification, became some of the first sedimentary rocks of the Earth, forming massive layers of graywackes and also iron rich material. This was an active time for the Earth's crust and intruding into the volcanic islands and graywacke sequences were granitic magmas rising from the mantle. The intrusion of this felsic material into the mafic volcanics and uniform sedimentary rocks caused deformation and metamorphism. This granitic material along with the schist and gneisses formed from the metamorphism, and the sedimentary rocks not metamorphosed became the material of the first continental crust. ${ }^{2}$

The Archean, lasting from the formation of the Earth 4.6 billion years ago to 2.5 billion years ago, was a time of massive generation and assembly of continental crust. The basic volition for the movement of continental plates, the divergent spreading margins were active, generating oceanic crust that eventually subducted beneath the less dense continental crust, in the reciprocal, conveyer belt motion of plate tectonics. Over the course of millions of years, continental terranes accreted with other masses of continental crust in slow but profound tectonic collisions creating orogenic mountain building episodes and increasing the size of the continents. By the end of the Archean, 2.5 billion years ago, one large continent had taken shape, only later to be broken up into 
separate continents and reunited yet again as the meandering of the Earth's continents continued.

The Proterozoic, the second stage of Precambrian time, extending from 2.5 billion years ago to 600 million years ago, witnessed the continuation of continental migration. The Lake Superior area rifted apart 2.3 billion years ago, and as it separated the ocean invaded the area, depositing sand and gravel, dolomite and iron formation. ${ }^{3}$ These sedimentary rocks would later play a vital role in the settlement and economy of the Marquette Range. Approximately 1.9 billion years ago, the meandering terranes of continental crust and island arcs again changed direction, colliding once again to create a period of massive deformation called the Penokean Orogeny. This major tectonic mountain building event heavily metamorphosed the rocks involved in the collision, creating a series of large scale faulted and folded features as large as the present day Rocky Mountains. The Penokean Mountains stretched from Iowa to Ontario with the range's roots present in the rock record of today. Always, the immutable force of erosion has broken down and redeposited the rocks of the Lake Superior area and by the Middle Proterozoic, 1.6 to 1 billion years ago, the Penokean Mountains were reduced to nothing more than rolling hills. ${ }^{4}$

Approximately 1.1 billion years ago, the plates began to stir for the last time with a hot spot under what is now western Lake Superior bulging up and forcing the continental crust to split. The Mid-Continent Rift formed as a result of this divergent regime and enormous quantities of lava spilled out onto the surface. The rift never fully pulled the continent apart and by the late middle Proterozoic, one billion years ago, the tectonism of the Lake Superior area halted, never to resume; for a billion years the region has remained tectonically stable and quiet. ${ }^{5}$

Although the foundation of this complex and ancient terrane has remained fixed and permanent for nearly a quarter of the history of this planet, with no tectonic activity, important changes have occurred. On the surface erosion continued to wear down the rocks and under the ground, water helped to concentrate iron formation into rich deposits of ore. With the beginning of the Paleozoic Era, 570 million years ago, changes in sea 
level caused the ocean to cover much of North America. This encroachment of the sea approached the Lake Superior area, within sight of the Marquette Range and deposited thick and spatially extensive sedimentary rocks. Glaciers, active in the area for billions of years, last invaded the region in the Quaternary, 1.6 million years to present, redepositing surface material and leaving behind the Great Lakes. Their final retreat occurred at the end of the Wisconsinan glaciation, approximately 8,000 years ago. Finally, man evolved on the plains of East Africa 1.5 million years ago, developing over time into a creature capable of digging up a great deal of the iron that had lain dormant for thousands of millennia, in an extraordinarily short period of its long existence.

Figure $2^{6}$, and the legend for the figure on the next page show the distribution of the rocks of an area extending from the central Upper Peninsula of Michigan to east of Ashland, Wisconsin. Bounded by Paleozoic cover to the southeast and Keweenawan midcontinent rift material to the northwest, a complex area of continental margin assemblage is present as the main focus of the map in the center.

\section{The Archean}

The Archean rocks of the Lake Superior area comprise the southern part of the Superior Province. This province is a large, mostly undisturbed Archean terrane that represents the heart of the North American continent and was the building block for the many younger accretions of rock that give the continent its current spatial distribution. These Archean rocks consist predominantly of two major bands or belts: greenstone belts and gneiss belts. Greenstone belts consist of long, linear units of tightly folded volcanic and sedimentary rocks derived from the erosion of volcanics and typically surrounded and intruded by granites that separate adjacent belts of greenstone. The volcanic rocks that form these belts consist mostly of basalt which erupted underwater in the ocean with the minerals olivine, chlorite, actinolite, and epidote making up the basalt and giving the greenstone belts their typically dark green color. Andesitic and rhyolitic volcanics are commonly associated with the greenstone belts, though always subordinate to the basalt in quantity, and sedimentary rocks, derived from the volcanics, also are present in the 


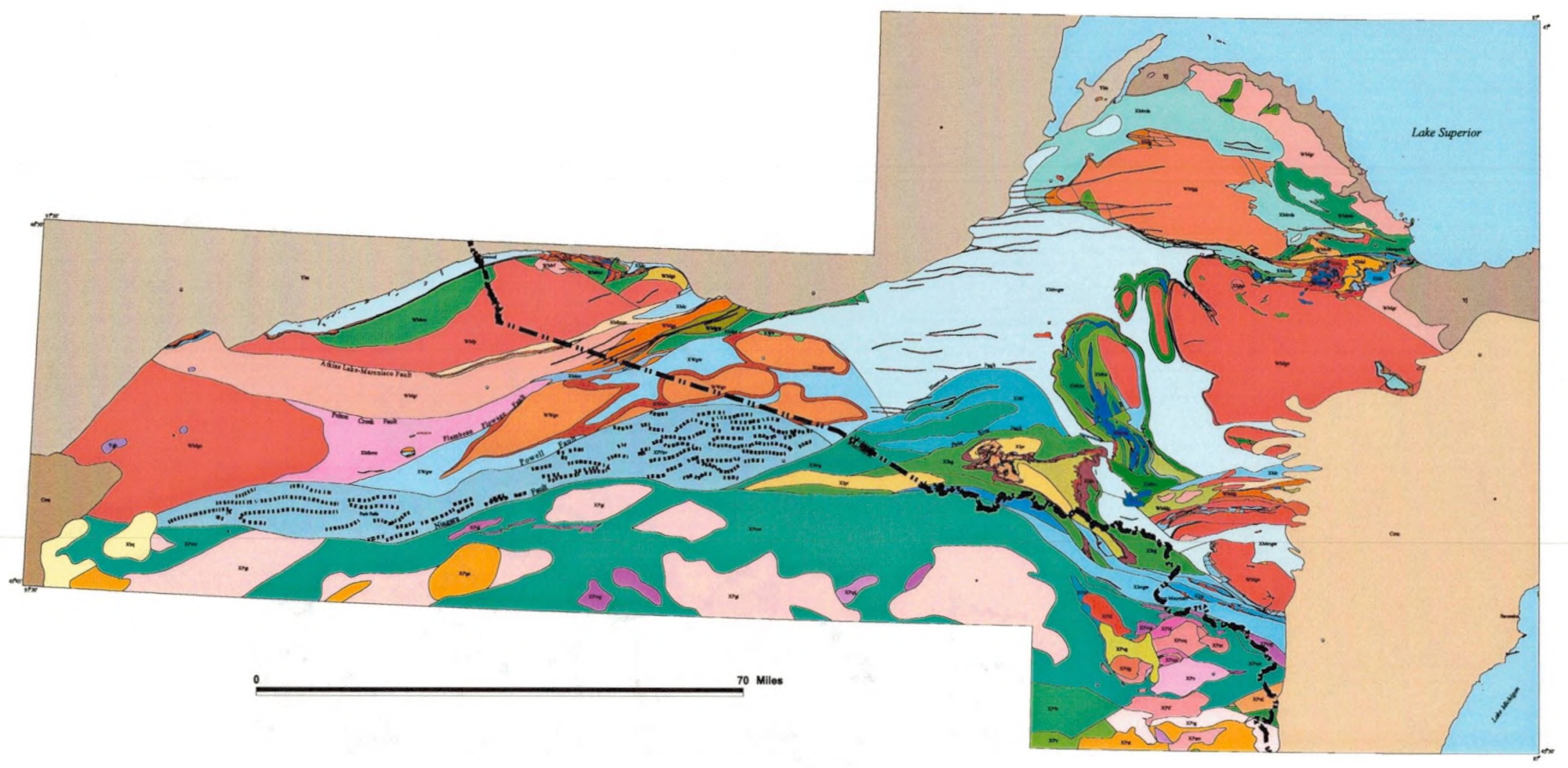




\section{Paleozoic Strata}

CMu Munising Sandstone

Cms Mt. Simon sandstone

\section{Middle Proterozoic}

Yku Keweenawan rocks undivided

Yj Jacobsville Sandstone

Ygb Gabbro

Yd Diabase dike

\section{Early Proterozoic and Archean}

\section{Penokean Fold and Thrust Belt}

Michigamme Subterrane

XMai Anorogenic granite

XMmd Metadiabase

XMbme Chocolay-Menominee-Baraga Groups undivided

XMbmu Menominee-Baraga Groups undivided

XMe Copps Formation

XMt Tyler Formation

XMvs Volcanic-sedimentary unit

XMmv Michigamme Formation-volcanics

XMmgw Michigamme Formation-graywacke

XMmi Michigammer

XMmbi Michigamme Formation-Bijiki Iron-formation

XMmgi Michigamme Formation-Greenwood Iron-formation

XMmev Michigamme Formation-Clarksburg volcanics

XMme Michigamme Formation conglomerate

XMmls Michigamme Formation-lower slate

XMg Goodrich Quartzite

XMmu Menominee Group undivided

XMn Negaunee Iron-formation

XMsi Siamo Slate

XMaj Ajibik Quartzite

$X M v$ Vulcan Iron-formation

XMef Emperor Volcanics-felsic

XMem Emperor Volcanics-mafic

XMi Ironwood Iron-formation

XMp Palms Formation

XMam Amasa Iron-formation

XMfr Fence River Iron-formatio

XMhu Hemlock Volcanics undivided

XMhs Hemlock Volcanies metasediments

XMhrh Hemlock Volcanics metarhyolite

XMhi Hemlock Volcanics iron-formation

XMhbr Hemlock Volcanics breccia and pyroclasic rocks

XMhb Hemlock Voleanics basalt flows

XMmm Quartzite at Michigamme Mountain
XMbem Blair Creek Formation magnetic unit

XMbe Blair Creek Formation basalt and graywacke

XMbe Basal conglomerate

XMw Wewe Slate

XMi Kewe Slate

XMm Kona Dolomite

XMm Mesnard Quartzite

XMel Enchantment Lake Formatio

XMsb Sunday-Bad River undi

XMbr Bad River Dolom

XMs Sunday Quartzite

XMr Randville Dolomite

XMst Sturgeon Quartzite

XMfc Fern Creek Formatio

WMpg Palmer Gneiss

WMpr Peridotite

WMpr Peridotite

WMp Puritan Quartz Monzonite

WMgs Gneiss and schist

WMgs Gneiss and schist
WMrp Ramsey Formation-pyroclastic rocks

WMrf Ramsey Formation-felsic volcanics

WMrm Ramsey Formation-mafic flows

WMrc Reany Creek Formation

WMmn Mona Formation Nealy Creek Member

WMmb Mona Formation basalt

WMmr Mona Formation rhyolite tuff

WMk Kitchi Formation

WMgw Graywacke

WMdu Dickinson Group undivided

WMdeb East Branch Arkose

WMds Solberg Sehist

WMsm Six Mile Lake Amphibolite

WMam Amphibolite

WMa Amphibolite

WMgr Granitic rocks

WMgg Granite and granitic gneiss

WMga Gneiss and amphibolite

WMgn Gneiss

XMme Goodrich Conglomerate
Watersmeet Subterrane

XWv Volcanic rocks

XWgw Graywacke

$\mathrm{XWbm}$ Basal magnetic unit

WWgn Gneiss

Beechwood Subterrane

XBgv Graywacke and volcanic rocks

XBif Iron-formation
XBvg Volcanic rocks and graywacke

Park Falls Subterrane

$\square$ XPFsv Sedimentary and volcanic rocks

Iron River Subterrane
XImg Metagabbro
XIipr Paint River Group undivided
XIf Fortune Lake Slate
XIh Fortune Lake Slate
XIhg Hiawatha Graywacke
XIde Dunn Creek Slate
XIdc Dunn Creek Slate
XIbg Badwater Greenstone
XImgw Michigamme Formation-graywacke
XImq Michigamme Formation-quartzite
XImq Michigamme Format
XIv Vulcan Iron-form
XIfe Felch Formation
XIsh Saunders Formation-Hiawatha Graywacke
XIsh Saunders Formation-
XIsa Saunders Formation
XIsa Saunders Formation
XIra Randville Dolomite
XIst Stambaugh Formation
XIsh Stambaugh Formation-Hiawatha Graywacke

Wisconsin Magmatic Terranes

Pembine-Wausau Subterrane

\begin{tabular}{|l}
\hline XPtf Twelve Foot Falls Quartz Diorite \\
XPse Spikehorn Creek Granite \\
XPqd Quartz diorite \\
XPdi Diorite \\
XPn Newington Tonalite \\
XPnm Newington Tonalite megacrytsic facies \\
XPat Athelstane Quartz Monzonite \\
XPbl Bush Lake Granite \\
XPam Amberg Granite \\
XPmq Marinette Quartz Diorite \\
XPhl Hoskins Lake Granite \\
XPgt Granite and tonalite \\
XPga Granitoid rocks anorogenic \\
XPdg Dunbar Gneiss \\
XPmg Metagabbro \\
XPm Metasedimentary rocks \\
XPrg Rhyolite. felsic tuff graywacke \\
XPrd Rhyolite and dacite \\
\hline XPv Volcanic rocks undivided \\
XPvg Volcanic and granitic rocks \\
XPbab Basaltic and andesitic breccia \\
XPo Ophiolite \\
XPmv Mafic volcanic rocks \\
XPfv Felsic volcanics and sediments \\
\hline
\end{tabular}


belts. Throughout the Canadian Shield, the volcanic and sedimentary rocks make up linear belts hundred of kilometers long in places, and typically tens of kilometers wide. ${ }^{7}$ After the early volcanic eruptions in the Archean, the rocks of the greenstone belts were subjected to low intensity metamorphism resulting mostly in a chemical reconstitution of the rock and compression deforming the volcanics into u-shaped, trough like synclines. Typically, the basaltic material forms the bottom or outside of the trough, the rhyolitic material next, with overlying, sometimes interbedded thick sequences, 10,000 feet or more, of sedimentary rocks forming the center of the trough. ${ }^{8}$ The sedimentary rocks, poorly sorted graywackes, consist of accumulations of angular sand-sized grains of eroded quartz and feldspar from the volcanics typically in a matrix of chlorite or sericite rich clay. Although early Proterozoic iron formations have yielded the vast majority of iron in the Lake Superior area -roughly 92 percent of it- the Archean greenstone belts also included iron formations. The Archean iron formations consist mainly of chert and magnetite, with hematite and some siderite and pyrite present as well. Within the greenstone belts of the cratonic parts of the continents important concentrations of zinc, copper, gold and nickel are also found. ${ }^{9}$

Separating the greenstone belts are large area of granitic rocks. Granitic rocks are more predominant than the greenstone belts they separate with the granite making up roughly 85 percent of the shield areas. ${ }^{10}$ These granitic rocks were formed through partial melting of the magma or of the melting and recrystalization of the volcanics and graywackes. The same metamorphic forces that shaped the greenstones into trough like, synclinal structures also affected the granites, and where the forces were particularly strong, belts of gneiss formed. The gneisses, covering an extensive area, contain schist representing metamorphosed graywackes. The structure of the gneiss belts, though generally linear, is very complex and represents the collision regime that characterized the late Archean conglomeration of continents. In the Lake Superior area the Great Lakes Tectonic Zone, a major tectonic suture, extending for roughly 600 miles, forms a major shear zone established during the late Archean amalgamation of the Superior Province. The suture represents an ancient boundary between an exotic terrane and the 
continental crust it collided into during the accretionary processes that formed a supercontinent at the end of Archean time. ${ }^{11}$

\section{Early Proterozoic}

In the Lake Superior area, three major occurrences dominated the geologic evolution of the area during the 900 million years of the Early Proterozoic. The occurrences, both erosional and tectonic, left behind a wide variety of rocks and structures which would profoundly affect the history of humans. The large supercontinent that had come together in the late Archean underwent a long period of erosion during the first 200 million years of the Early Proterozoic and this erosional episode marked the first of the three major occurrences of the period. Because terrestrial plants had yet to evolve, the granitic continental crust, crossed by greenstone and gneissic belts, and with large areas of volcanic material and graywackes had no land vegetation to support against erosion, and the barren landscape was quickly reduced. The extensive erosion unearthed deeply buried metamorphic rocks which formed at depth, and these gniesses and schists that formed kilometers beneath the surface are commonly exposed at the ancient erosional surface. ${ }^{12}$

The second major occurrence of the Early Proterozoic began roughly 2.3 billion years ago when the Archean supercontinent began to rift apart. The rifting, driven by plate tectonism, occurred due to increased magmatic activity in the mantle and increased spreading at divergent plate boundaries. One of the major rifts involved in this plate separation extended from what would later be known as Western Minnesota, through Northern Wisconsin, and the Upper Peninsula into Ontario. This east-west break in the crust divided two regions that slowly began to diverge, causing subsidence of the continental crust. The down-dropped block fell below sea level and the ocean encroached over much of the Lake Superior area. This subsident, divergent continental trough filled with an arm of the sea, referred to as a passive margin, and changed the Lake Superior area from a non-marine erosional environment to a marine depositional one. ${ }^{13}$ When the sea advanced over the Archean greenstones and granite, the first layer to 
be deposited, or the basal unit, was a quartz sand and gravel. The lithification of this layer produced sandstone and conglomerate that through later metamorphism became the Mesnard quartzite of the Marquette Range. Overlying the quartzite, a carbonate dolomite layer several hundred feet thick was deposited. The dolomite, a chemically precipitated rock composed of calcium-magnesium carbonate, formed in a shallow, offshore environment with life present. Stromatolites are common in the scattered erosional remnants of the dolomite which on the Marquette Range is represented by the Kona Dolomite. The quartzite and dolomite together are referred to as the Chocolay group. As the passive margin spread, a large east-west basin, the Animikie Basin, formed, and a thick sequence of sandstone, shale, iron formation, and graywacke, collectively known as the Menominee Group, was deposited on top of the Chocolay Group which had been mostly removed by erosion prior to Menominee deposition. Again the basal deposition of the Animikie Basin was sand and gravel, which through lithification and later metamorphosis became the Ajibik Quartzite. ${ }^{14}$ This quartzite, along with the Mesnard, form distinctive and resistant layers on the Marquette Range and have affected transportation patterns and settlement patterns throughout the human history of the Range. The first iron forge was located where the Carp River cuts through the Ajibik quartzite forming a location for a dam, and during the expedition of 1841 Douglass Houghton used the resistant ridge of what would later be known as Mt. Mesnard to make some of the initial scientific observations of the Marquette area. ${ }^{15}$

\section{Iron Formation}

Biochemical deposition, very rich in iron, occurred between 2.2 and 2.1 billion years ago. The deposition, overlying the basal sandstone and conglomerate, is made up primarily of biochemically precipitated quartz or chert and iron bearing minerals, varying widely in color and appearance and either banded or granular. The banded iron formation contains layers of chert, uniform in thickness of generally less than a centimeter, interbedded with minerals such as magnatite, hematite, and siderite. Granular iron formation is made up of chert layers that vary greatly in thickness, with a maximum 
of roughly 15 centimeters, alternating with thinner layers of iron-rich minerals. The chert layers in this case contain round granules of sand grain size set in the chert matrix. ${ }^{16}$

The bedding characteristics of the two types of iron formation show that the likely environment for the deposition of banded iron formation was in deep, calm marine environments, with the granular formations deposited in shallow more active environments. A wide variety of fossilized life forms are found in these Proterozoic deposits including stromatolites, microbial mats, and fossilized bacteria and algae. In the Animikie Basin these life forms, many photosynthetic, oxygen producing microorganisms, employed the iron to precipitate an insoluble iron-oxide that was the precursor to much of the iron-formation. Near the surface of the water, the oxygen produced from the photosynthesis caused the water to be oxidizing, however, deeper in the water where light was scarce the water was reducing and this was where the siderite and hematite of the Marquette Range formed. ${ }^{17}$

Most of the iron formation deposited during this time has remained primarily unaltered, however, select parts of the iron formation were converted to iron ore through secondary oxidation and leaching that occurred after deposition. These select areas became the iron mines of the $19^{\text {th }}$ and early $20^{\text {th }}$ centuries on the Marquette Range. Groundwater that circulated through the iron formations altered the original rock by oxidizing the iron bearing minerals present in the rock to the ferric state. The water converted the soluble iron minerals in the rock to highly insoluble minerals such as hematite, goethite, and limonite. As more groundwater circulated through the rocks the water dissolved the silica, calcium and magnesium in the rocks and leached it out of the iron formations. This left the material porous and led to the concentration of insoluble iron-bearing minerals where they reached an iron-content of up to 60 percent. Many of the deep underground ores of the Marquette Range gathered in troughs of impermeable sedimentary layers or basaltic dikes where they were concentrated. ${ }^{18}$

Iron formation deposition occurred in large parts of the globe during the early Proterozoic. Only the oldest parts of the continents, the continental shields, where rocks existed during the early Proterozoic, contain sequences of iron deposition. Some of these 
deposits are very large, measuring between 500 and 2000 feet thick and spatially extensive. After the early Proterozoic, two billion years ago, massive iron formation deposition ceased and the rock is almost entirely absent from younger sedimentary rocks. This occurred due to a major surface environment chemical change with the Earth, at this point, developing an oxygen rich atmosphere. Because iron is relatively soluble in oxygen-deficient environments and insoluble in oxygen-rich environments, following the development of this atmosphere, the iron formations ceased to form. ${ }^{19}$

The iron ore mined in the first century of production on the Marquette Range was shipped directly from the mine to the blast furnace. The high-grade ore did not need processing before smelting. However, beginning in the 1950's and extending into the present day, the mining of iron on the Marquette Range and throughout the Lake Superior area has changed from the mining of high grade iron ore, which has been mostly depleted in the area, to the mining of low grade Taconite ore. Taconite is iron formation that has not been oxidized nor naturally concentrated. Before it can be smelted taconite must undergo a processing phase that involves the mechanical separation of magnetite from granular iron formation and then the concentration of that material into pellets. ${ }^{20}$

Overlying the iron-formation on the Marquette Range is the Baraga Group which consists of the Goodrich Quartzite and an extensive deposit of graywacke and slate of the Michigamme Formation. The graywacke was formed by the erosion of granitic terranes still present in the area and also through the erosion of basaltic flows resulting from the Early Proterozoic rifting. Basaltic dikes and sills are prevalent in the rocks of this period. $^{21}$

\section{The Geology of the Marquette Range}

The Marquette Range consists generally of a complex folded and faulted synclinal structure that gently plunges toward the west. The synclinorium is made up of early Proterozoic strata that, due to the westward dip of the structure, are generally exposed on the surface from west to east in the chronological order in which they were deposited. Progressing from the east, in the order in which they were deposited, Figure $3^{22}$ illustrates 


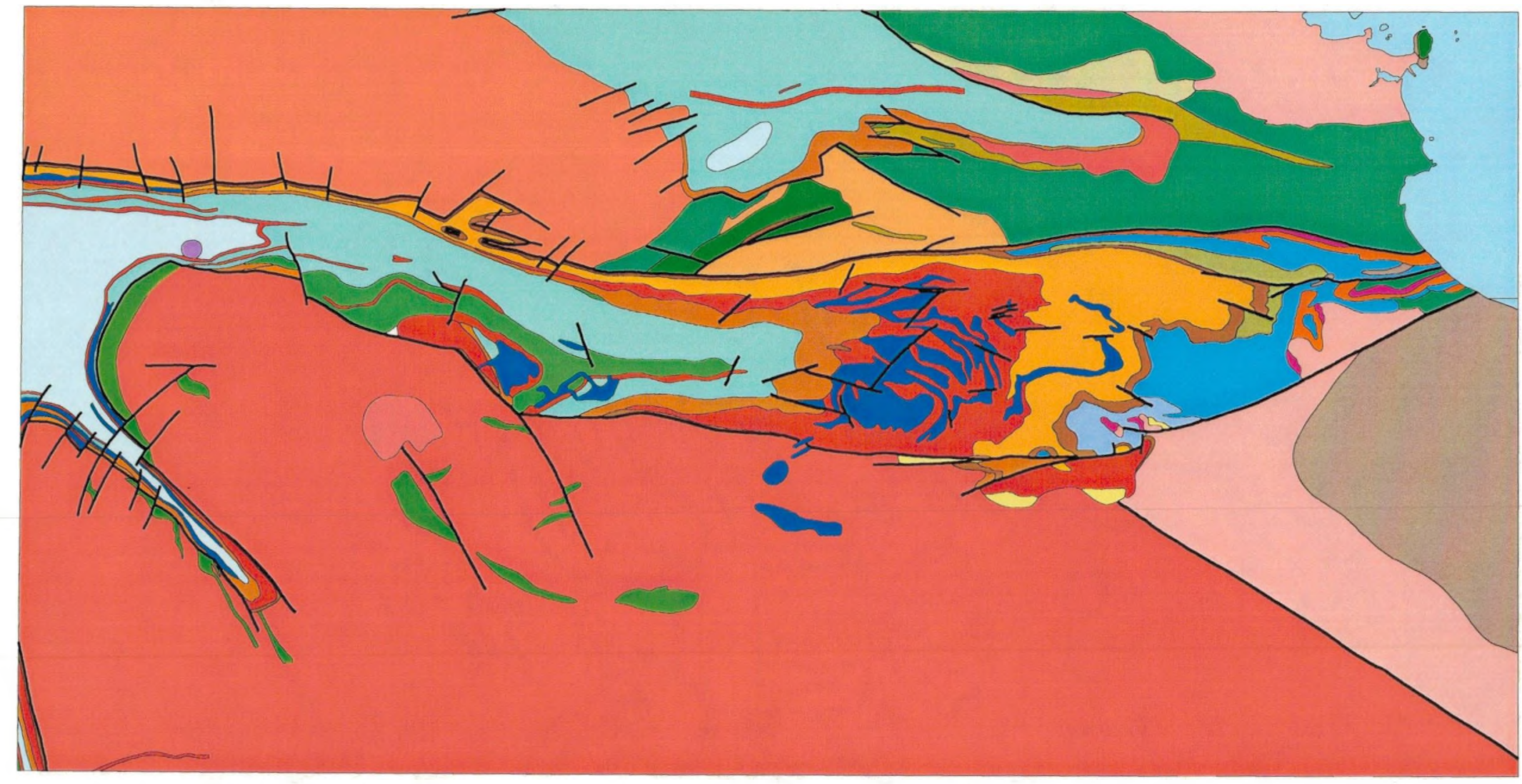

Figure 3. Geologic Map of the Marquette Range 
that the Mesnard Quartzite is overlain by the Kona Dolomite and then the Wewe Slate, the Ajibik Quartzite, and the Siamo Slate. Deposited on top of these older rocks, exposed because of the dip of the strata to the west of the units, the Negaunee Iron Formation outcrops extensively at the surface. Highly resistant intrusive diabase sheets are present within the Negaunee Iron Formation and generally outcrop as the high ground of the area, with the iron formation found in the low ground between the intrusives. Above the iron rich rocks, the Goodrich quartzite and the units of the Michigamme Formation including the lower slate and Clarksburg Volcanics continue the stratagraphic sequence of younger rocks exposed with the progression westward.

Deformation of this strata, causing the sedimentary and igneous rocks to be metamorphosed and establishing the synclinorium structure of the Range occurred during the Penokean orogeny, which was the third major geologic occurrence of the Early Proterozoic. The synclinorium appears as an elongated strip of younger Proterozoic rocks within a much more spatially extensive area of older Archean volcanic and granitic rocks. This appearance is due to the synclinorium having been bounded by east-west trending faults both to the north and south. ${ }^{23}$

The evidence for the deformation present in the structure of the Marquette synclinorium and the sometimes intense metamorphosis of the sedimentary rocks of the Range is absent in the Archean rocks that lie just to the north and south of the Range. The reason for this seemingly contradictory evidence is that during Penokean deformation, which will be discussed in more detail in the next section, the Archean rocks acted as mostly rigid, fault-bounded blocks, and were structurally decoupled from the Early Proterozoic strata. The Marquette Synclinorium acted as a down dropped graben relative to the Archean rocks, creating the spatial distribution of the rocks of the Marquette Range and creating a mostly linear, east-west trending mining district. ${ }^{24}$

\section{Penokean Orogeny}

The divergent continental breakup of the Early Proterozoic lasted for roughly 150 million years with the extensive deposition within the passive continental margin 
represented, in part, by the strata found on the Marquette Range. Approximately 1.9 billion years ago the movement of the plates changed and a convergent regime ensued, with this change in the plate motion and the subduction of oceanic crust resulting in a radically changed rock record. The subduction led to partial melting of the subducted plate and volcanism on the Earth's surface that created an island arc consisting of basalt and some rhyolites and andesites that later collided into the craton containing the rocks of the Lake Superior area, causing deformation and a mountain building episode. The Penokean Orogeny, which lasted for 50 million years, marked the final phase of convergent tectonics in the Lake Superior area and built a large mountain range from Northeastern Iowa to Ontario. ${ }^{25}$

The Penokean orogeny began 1.89 billion years ago and was the third and final significant geologic occurrence in the Early Proterozoic. The collision between the Superior Craton and the island arc, occurring 1.86 billion years ago, caused extensive deformation of both terranes. The Niagra Fault zone, which extends from northern Wisconsin through the Upper Peninsula (see Figure $4^{26}$ ), is the remnant of the zone of collision between the two terranes and is a broadly arcuate, convex-northward paleosuture consisting of several faults that diverge and recombine along its length. ${ }^{27}$ The result of the orogeny is an area of highly metamorphosed sedimentary and igneous rocks in the Lake Superior area.

Extensive thrust faulting occurred during the orogeny, forcing the material of the original terrane and also rock from the island arc north onto the Superior Craton. This is shown graphically in Figure 4. The Pembine-Wausau Subterrane in the southern part of the area is representative of the exotic island arc terrane that accreted to the rocks of the north during the Penokean collision. The Niagra Fault, as discussed earlier, separates the island arc terrane from the rocks that the arc collided into. The Michigamme Subterrane in the north represents the cratonic rocks the island arc accreted onto, that though heavily deformed by the collision, were not moved a considerable distance. In between those two subterranes, the Watersmeet, Park Falls, Beechwood, and Iron River Subterranes were pieces of the craton that were thrust northward as a result of the 
Mid-Continent Rift Keweenawan Volcanics

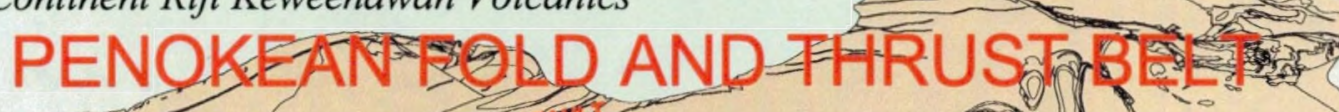

MICHIGAMME SUBTERRANE COUN SUICHGACUME SUBTERRANE

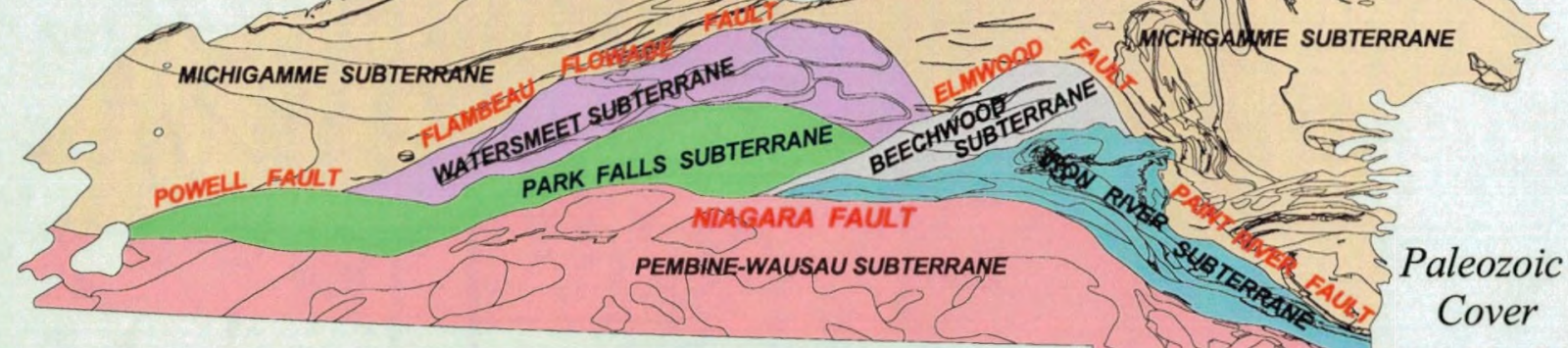

\section{WISCONSIN MAGMATIC TERRANES}

Cover

Figure 4. Subterranes and Major Faults of the Penokean Continental Margin Assemblage 
massive and violent collision of the Penokean Orogeny. These allocthonous pieces were pushed northward sliding over the autocthonous Michigamme Subterrane along the Flambeau Flowage, Powell, Elmwood, and Paint River Faults. ${ }^{28}$

This major compressional occurrence created the Penokean Mountains in the Lake Superior area, a mountain range comparable to the present day Rocky Mountains. The compressional forces were north-south in direction, with the result of the compressional forces being complexly faulted, large synclines and anticlines. The large compressional forces and the high temperatures created by the collision metamorphosed the sedimentary rocks of the area into the slates, schists, and quartzites in existence today. As the compression slowly decreased, the rebound of these two colliding terranes forced divergence, and granitic and rhyolitic material intruded the highly deformed terrain, further adding to the content and distribution of the rock matrix. ${ }^{29}$

\section{The Middle and Late Proterozoic}

Extending from 1.6 to 1 billion years ago, the middle and late Proterozoic involved igneous activity, deposition and extensive erosion. The Penokean Mountain Range underwent erosion for 500 million years after its formation in the Early Proterozoic, and the eroded material extended outward away from the mountains, depositing sediment that would later form layers of sandstone, conglomerate, and mudstones throughout the Lake Superior Area. By 1.2 billion years ago the Penokean Mountains were eroded into a low, rolling plain. ${ }^{30}$

The quiescent period of erosion was interrupted by the last major tectonic event in the area that began approximately 1.1 billion years ago and lasted for a brief 15 million years. This event was defined by extension in which the continental crust, consisting of Archean and early Proterozoic rocks, nearly broke apart completely, with a great amount of basaltic, volcanic material flowing up through the crack onto the surface. The extensional regime was triggered by upwelling basaltic material from the mantle invading the rocks beneath the present day western Lake Superior area, with upwelling from the hot spot in the mantle forcing the crust to bow, producing a doming of the surface. The 
dome, roughly 100 miles wide and 1000 miles long, produced large scale tensional forces, causing the crust to split, and the Mid-Continent Rift to form. This rift formed a linear zone of subsidence, cutting across the domal feature, bounded by faults on the outside, with down dropping blocks of sediments that were later covered by basalt lava flows. ${ }^{31}$ The rift extended from eastern Kansas up to Lake Superior and then curved down into the eastern Upper Peninsula, and lower peninsula of Michigan with basaltic lava flows spread out in extensive layers covering up to 100 miles of land away from the main rift. The basalts were thickest in the main rift area, up to twelve miles thick, as down dropped blocks continued to subside. As the rifting and volcanic activities ceased, an effect of compression from the Grenville Orogeny forming the Appalachian Mountains far in the east, the basalts were eroded and redeposited as mostly fluvial, clastic sedimentary material. The rifting signified an end to major tectonic deformation in the Lake Superior area and ushered in a billion year era of stability and erosion. ${ }^{32}$

A belt of flat-lying sandstone, the result of erosion and deformation on a land surface in a stream and lake environment within Keweenawan time lies along the present day southern shore of Lake Superior in the Upper Peninsula stretching from the Keweenaw Peninsula eastward to Munising (see Figure 1). This sandstone, known as the Jacobsville, ranges in thickness from less than 50 feet to more than 1,000 feet and is a red to brown impure sandstone commonly used for building stone throughout the area. ${ }^{33}$ It is the only rock of Keweenawan age, associated with the Mid-Continent Rift, present on the Marquette Range. Outcropping near Lake Superior on the Range, visibly overlying the Mesnard Quartzite, the Jacobsville was deposited a billion years ago in a topographic environment very similar to the present day environment. The flat lying Jacobsville is exposed on the flank of Mt. Mesnard, approximately 370 feet above the present day lake level, indicating a Precambrian topographic relief and ruggedness roughly equal to the present day relief. ${ }^{34}$ Southeast of the Marquette Range, the Jacobsville lies on top of the Kona Dolomite which outcrops in an abrupt cliff that marks the southeastern edge of the Range. The Jacobsville Sandstone continues toward the east and the area of Grand Island and Munising, however, the topography in this direction is much more subdued and flat 
lying, as it must have been in the Precambrian, hence, the outcrop of the Kona Dolomite marks a natural boundary separating the flat-lying younger sedimentary rocks of the east from the highly deformed, complex and more rugged older rocks to the west. The change was a very important landmark in the early history of the Marquette Range, consistently referred to in the literature and early accounts of the area.

\section{The Paleozoic}

The Paleozoic Era began 570 million years ago. At this point, the continent of North America, though still missing some integral parts, was very nearly the size and shape that it is today. In the Cambrian, sea level rose in relation to the continent and the water slowly began to encroach over the land. The process was very slow, and a lifetime would have witnessed no recognizable change; it took the water 100 million years of advancement to reach the Lake Superior area, and as it progressed, the water deposited thick layers of sediments on the continent. ${ }^{35}$ As the sea encroached, it was diverted into low areas on the continents, filling the barely perceptible topographically low basins, and surrounding the topographically high arches. When the sea finally reached the Lake Superior area, it washed up against the Wisconsin Arch, a topographically high, broad expanse of land that prevented the sea from encroaching onto the rocks of much of the western Upper Peninsula including the Marquette Range. The sea stopped southeast of the Range, depositing thick sediments over the Precambrian rocks, and a boundary was created, separating the flat lying sedimentary sequences of young sandstones from the heavily deformed and complex Archean and Proterozoic rocks of the Western Upper Peninsula. The boundary is clearly apparent in Figure 2. The seas washed up onto the high ground of the Wisconsin arch and then slowly withdrew. Just south of the Marquette Range these transgressive sequences are represented by the Chapel Rock and Miners Castle sandstones of the Munising Formation; both units represent shallow, near shore environments, showing that the sea barely covered much of the Upper Peninsula. Further to the east on the Upper Peninsula, the Paleozoic rocks are represented by very 
level Cambrian sandstones, overlain by limestone and dolomite, partially covered by glacial and glacial lacustrine deposition. ${ }^{36}$

\section{The Pleistocene}

Approximately three million years ago, the global climate became substantially colder. As the temperature dropped, the precipitation that fell as snow failed to melt off completely during the warmer months, and large accumulations of snow and ice began to form. The bottom layers of this frozen precipitation were compacted by weight and, gradually, as the weight increased, the ice began to flow. During the Pleistocene, the maximum spatial extent of glaciation reached 30 percent of the land surface; the thickness of the ice reached as much as 10,000 feet, with up to eight percent of the Earth's water taking the form of glacial ice. This large amount of ice had a profound effect on the globe; it lowered sea level several hundred feet and its massive weight depressed the continental crust by as much as 2000 feet. ${ }^{37}$ Beginning 2.5 million years ago, several glacial advances affected much of the Lake Superior area. As the glaciers slowly advanced over the land, everything in their path was decimated and enormous amounts of surficial material was redistributed. During interglacial periods, as the ice retreated, erosion occurred on the rocks, and vegetation grew back. Each succeeding period of glaciation wiped out much of the evidence of the previous episode, so that much of the evidence for glacial deposition in the Lake Superior area comes from the last glacial advance, the Wisconsinan, which began 100,000 years ago and ended approximately 10,000 years ago.

The Wisconsinan glaciation was marked by several advances and retreats of the ice, and left behind a complex pattern of landforms exemplified in the present day distribution of the soils of the region. Glacial deposits in the western Upper Peninsula are thin and there are few areas of outwash and glacial lakes. The streams and rivers of the area that flow northward and empty into Lake Superior flow at a steep gradient and run mostly over the Precambrian bedrock, however, in the eastern Upper Peninsula, on the Paleozoic sedimentary cover, the rocks were less resistant to glacial erosion and were 
shaped into broad, flat, poorly drained areas. Glacial and glacial lacustrine deposits are common in these areas. ${ }^{38}$

Before Wisconsinan glaciation, a large east-west fluvial drainage developed in the sediments of the Keweenawan Midcontinent Rift zone. The river flowed along a broad syncline in the area and when glaciation began, as ice filled this river valley, the highlands of the Wisconsin arch inhibited the southern flow of the ice pushing it toward the west and east. Successive advances of the ice deepened the basin to over 1300 feet so that, by the time of the final recession of ice, a large and deep basin occurred, later to be filled in by the water of present day Lake Superior. The water level of Lake Superior has varied considerably since the retreat of glaciation, with crustal subsidence and rebound due to isostacy accounting for much of the fluctuation. By 7,500 years ago Lake Superior approximately achieved its current level and shape. ${ }^{39}$

\section{Conclusion}

The geology of the Lake Superior region has been examined, studied, and argued about continuously for more than 150 years. An expedition led by Douglass Houghton came to this area to specifically study the rocks in 1842, when very few European American settlements existed in the area, and when much of the area was wilderness. In 1844 , the land was surveyed and the rocks were systematically examined along the Township lines by William Burt. Charles Jackson, J.W. Foster, and J.D. Whitney came in the late 1840's describing the geology in two reports, and T.B. Brooks came shortly after them to write of the rocks. Since these pioneers of the early geology of the Lake Superior area, innumerable descriptions of these complex rocks have been attempted. Nearly all of the early descriptions of the rocks of the area were tied to the mineral wealth of the rocks with the early discovery of very large and valuable iron deposits on the Marquette, Menominee, Gogebic, Mesabi and Vermillion Ranges, and copper deposits on the Keweenaw Peninsula inspiring descriptions of these rocks, while geologic inquiry was still a young and evolving field. The complex and very old rocks have been slow to give up their secrets and key advancements in the knowledge concerning these rocks has 
come about only in the last three decades, as geologic inquiry has evolved. Geophysical analysis in the form of aeromagnetic and gravity anomaly maps, and seismic reflection profiling have recently allowed geologists to trace geologic structures beneath the Paleozoic cover to get a better idea of the nature of the deep rifts and sutures of the area. Detailed mapping of the complex rocks have only recently been completed and published while isotopic dating techniques have allowed the rocks to be dated more accurately and placed in an accurate chronometric framework. ${ }^{40}$

These rocks, only now beginning to be fully understood, record three billion years of the Earth's history. This geologic history, punctuated by rock-forming and tectonic events, rich and complex, has played a vital role in the history of the humans who have settled and live in the area. The distribution of iron rich rocks in the Archean and mostly early Proterozoic aged strata was the main influence on the original settlement of the Upper Peninsula of Michigan, Northern Wisconsin, and Northeastern Minnesota. This distribution of iron formation was determined first by the distribution of rifting in the area that allowed for the deposition of the rocks and then later by the Penokean Orogeny which greatly reworked the entire system. The result is a series of abstract, complexly shaped, iron rich units centered on the Marquette, Menominee, Gogebic, Mesabi and Vermillion Iron Ranges of the three states. However, not all of this iron rich material became concentrated into iron ore. The vagaries of the flow of groundwater, controlled by faults and joints in the rocks, and hindered by non-porous igneous dikes and shales, further affected the distribution of the iron formations not just on the surface but deep in the earth as well.

In addition to the iron, copper on the Keweenaw Peninsula, present in the rocks of the Midcontinent Rift were greatly influential to the settlement and economy of the area; gold and silver were also found in limited places within these rocks. The rugged nature of the complex and ancient rocks, and the effects of glaciation that left behind Lake Superior, affected transportation since the first Indians arrived in the area. The glacial deposition and the soils formed from the erosion of the bedrock were a locational determining factor for the forests of the area, which also was a key part of the settlement 
of the land. All of these factors show that within the ancient rocks of the area is expressed the resultant human history of the area; within the rocks, sometimes several billion years old, is written the history of the last 150 years. 


\section{End Notes}

${ }^{1}$ LaBerge, Gene L., 1994 Geology of the Lake Superior Region Geoscience Press, Inc. Tucson, Arizona., p.4

${ }^{2}$ Ibid. p.4,5

${ }^{3}$ Sims, P.K. and Carter, L.M.H, editors, 1996 Archean and Proterozoic Geology of the Lake Superior Region, U.S.A., 1993 U.S. Geological Survey Professional Paper 1556, United States Government Printing Office, Washington, p. 3

${ }^{4}$ LaBerge, Geology p. 112

5 Sims and Carter, Archean p.3

${ }^{6}$ This geologic map of the Penokean Continental Margin was created by William F. Cannon and Doug Ottke and will by 2000 be available as an open file report from the USGS. In this work the size of the map limits its usefulness, however, interested readers will be able to acquire the compact disc open file report meant for use in arcview, which in addition to the detailed geology, will also contain metallogeny information for the area with updated MRDS and Mas/Mills records.

${ }^{7}$ Sims and Carter, Archean p.8

${ }^{8}$ LaBerge, Geology p. 24

${ }^{9}$ Sims and Carter, Archean p. 90

${ }^{10}$ LaBerge, Geology p. 41

${ }^{11}$ Sims and Carter, Archean p. 9

${ }^{12}$ LaBerge, Geology p. 53

${ }^{13}$ Ibid., p.55

${ }^{14}$ Ibid., p. 61

${ }^{15}$ Much more on this topic will be discussed in chapter IV., as well as in the Conclusion.

${ }^{16}$ LaBerge, Geology p. 66

${ }^{17}$ Ibid., p. 75

${ }^{18}$ Ibid., p.78 and Sims and Carter, Archean p. 91

${ }^{19}$ LaBerge, Geology p. 74

${ }^{20}$ Sims and Carter, Archean p. 91

${ }^{21}$ Sims and Carter, Archean p. 33

22 This figure is a detail of Figure 1 and is the study area delineated in that figure. Please note that the formation colored red close to Lake Superior and present in small pockets amidst the Kona Dolomite and Mesnard Quartzite is -not- iron formation. It is the Enchantment Lake Formation. The nearest iron formation to Lake Superior is the Negaunee Iron Formation west of 87.5 degrees. The reason for this misleading representation is a printer which does not print the colors shown on screen. The compact disc mentioned in endnote \#6 will not have this problem.

${ }^{23}$ Cannon, W.F., 1999, Early Proterozoic Strata of the Marquette Iron Range: FortyFifth Annual Institute on Lake Superior Geology, Field Trip Guidebook, p.3

${ }^{24}$ Ibid., p.3

${ }^{25}$ Sims and Carter, Archean p. 28 
${ }^{26}$ Figure 4 has been constructed from the same GIS project shown in Figures 2 and 3 . This map shows another of the many attributes associated with each polygon in the project.

${ }^{27}$ Sims and Carter, Archean p.30

${ }^{28}$ Cannon, William F., and Schulz, Klaus J., Personal Communication.

${ }^{29}$ LaBerge, Geology p. 112

${ }^{30}$ Ibid., p. 130

${ }^{31}$ Ibid., p. 145

${ }^{32}$ This topic is far outside of the scope of this brief and cursory paper. For a more detailed discussion of the closing of the Midcontinent rift see: Cannon, William Closing of the Midcontinent rift-A far-field effect of Grenvillian compression, Geology, v.22, p.155-158, February, 1994

${ }^{33}$ LaBerge, Geology p. 166, 167

${ }^{34}$ Cannon, Early Proterozoic Strata p. 6

${ }^{35}$ LaBerge, Geology p. 184

${ }^{36}$ Ibid., p. 188

${ }^{37}$ Ibid., p. 243

${ }^{38}$ Ibid., p. 261

${ }^{39}$ Ibid., p. 290

${ }^{40}$ Sims and Carter, Archean p. 1 


\section{CHAPTER II. THE FOREST OF THE MARQUETTE RANGE}

Introduction/Pre-Human Forest/Early Human Impact on the Forest/

The Survey of the Land/The Logging of White Pine and Hemlock/ Hardwood Logging and Iron Production/The Kilns of the Marquette Range/ The Distribution of Sugar Maple and Yellow Birch on the Marquette Range/

The Charcoal Bloomeries/The Blast Furnaces/

Logging Associated With Shaft Mining/Conclusion

\section{Introduction}

Following Wisconsinan Glaciation, species of trees slowly dispersed northward into the region of the Marquette Range with the locational distribution of these arriving coniferous and deciduous species determined by their order of arrival and by the distribution of soils on the Range. ${ }^{1}$ The soils were, in turn, determined by the nature of the bedrock of the area, deposition occurring from glaciation in the area, and the process of weathering following glaciation. Approximately 3000 years ago, the distribution of forest species on the Marquette Range became for the most part stable; the species included, but were not limited to, large stands of sugar maple and yellow birch augmented by hemlock, white pine, and cedar. Finer scale variations of location with some species took place after 3000 years ago, with these changes occurring due to small scale climate change such as the Little Ice Age, natural disturbance caused by fire, wind, and flooding, insect infestation, and disease. ${ }^{2}$ However, these natural disturbances did not greatly influence the forest and because of the ecological stability of the area, when European-American settlers arrived on the Marquette Range, beginning in the mid-19 ${ }^{\text {th }}$ century, the forests they encountered were in an old growth condition. ${ }^{3}$ These impressive stands of timber conditioned settlement in the area, influencing the spatial distribution of property ownership. Humans, beginning with their first habitation of the area, quickly added to the natural disturbance, first, in very limited ways and later, with EuropeanAmerican settlement, in major, catastrophic ways. In the mid- $19^{\text {th }}$ century the timber of 
the Marquette Range became attached to a market economy and settlers first cut down the white pine and later moved on to the hardwoods to gain a monetary profit. Transporting the timber to market was a very influential aspect of this early stage of logging on the Marquette Range, influencing which stands were cut, and the infrastructure of the Range. During the white pine era the surface hydrology of the Range was modified as rivers were dammed to allow the transport of the buoyant timber. Fire was also greatly increased by large-scale settlement, destroying timber present on the Range and greatly modifying the future composition of the forest.

No greater impact was made to the forests of the Marquette Range than that of the impact associated with iron mining and production. In 1847 the first of four Catalan style forges was built on the Range to produce blooms of iron by taking advantage of the iron ore and hardwoods present in abundant supply. ${ }^{4}$ These first charcoal bloomeries were crude inroads into the sparse habitat and barely broken wilderness of the Range. None of the four realized a profit, however, they established that iron could be produced in the area, and their influence resonated throughout the era of iron production on the Range. Following in the footsteps of these bloomeries, a large number of charcoal fired blast furnaces were constructed on the Range starting in 1858 and continuing into the $20^{\text {th }}$ century. In 1865 there were five hot blast furnaces on the Range, and by 1873 there were 12. ${ }^{5}$ The local impact of these forges and furnaces on the forests was extreme. Radiating progressively outward from the insatiable demand of the smelting fire, few trees were spared the process of being slowly burnt, in beehive kilns, into charcoal and then used to smelt iron ore into pig iron in the forges and furnaces. Quickly, the hardwoods used to fuel the fires were removed from within close proximity of the furnaces, and new stands were found. Land ownership was the only requirement for completely removing timber from the land, and was a vital part of running a successful smelting operation, further influencing the spatial distribution of property ownership on the Marquette Range.

As the nature of iron mining on the Marquette Range began to change in the 1870s, the timber industry also changed. The surficial iron deposits of the Range had been exhausted, and with the advent of deep shaft mining a new relationship between the mines and forest was brought to fruition. In the underground operations, the safe and 
effective extraction of the ore necessitated the use of timber as supporting beams. This requirement added more to the demand placed on the ecology of the Range, and further progressed the diminishing supply of available, proximate timber.

By the beginning of the $20^{\text {th }}$ Century the communities of the Marquette Range were set in a matrix of cut-over and second growth woodland. The commercial value of the forest had been greatly reduced, affecting the nature of the economy and social structure on the Range. Regeneration of the former species was difficult with the soils that originally provided habitat for those plants damaged by erosion and fire. More adaptable species made inroads, greatly reducing the potential for the original habitat to return. New micro-climates emerged from the timber clear-cut, the hydrology of the Range was modified and many animal species lost habitat.

\section{The Pre-Human Forest}

The forests of the Marquette Range date to the end of the Wisconsinan glacial epoch, 10,000 to 14,000 years ago. ${ }^{6}$ The pre-major European-American settlement forests on the Range consisted of large areas of hardwoods and conifers interrupted on the landscape only by patches of scrubby pine and oak, lakes, wetlands, and bogs, and small outcrops of the rock of the Range. Natural disturbance in the form of windthrow, fire, disease and insect infestation affected the forests and left their mark on the landscape. ${ }^{7}$ The diversity of the forests represented in the multifarious species of hard and softwoods on the Marquette Range was established by the variant arrival times of the species and the complex landforms left behind by continental glaciation. ${ }^{8}$ As the climate warmed and the Wisconsinan ice sheet receded, plant and animal life slowly began to disperse northward, establishing themselves in the wake of the glaciation. From the southern Appalachian Mountains, the Ozark Mountains, the central great plains and the southeastern coastal plains, plant and animal species moved independently and dispersed at different rates, arriving on the Marquette Range under different climatic conditions. ${ }^{9}$ Forest communities progressed in rapid succession within the increasingly warmer conditions, and additional species arrived with frequency. As the ice margin regressed, tundra conditions following closely behind, spruce pine woodland with tamarack or larch 
were the first tree species to establish themselves in the post glacial terrain. Jack pine, red pine, balsam fir and later white pine followed the spruce and larch northward establishing themselves between roughly 11,000 and 10,000 years ago. The first deciduous tree to arrive in the area following glaciation was the oak, which arrived in the area roughly $11,000-10,000$ years ago, with maples arriving 8,000 years ago, and sugar maples 7,000-6,000 years ago. The most recent arrivals to the Marquette Range included the American beech and the hemlock, which both arrived roughly 4,000 years ago. ${ }^{10}$

Glaciation left behind level, poorly drained plains, pitted areas with numerous kettle lakes, morainic hills, and outwash sands, lake clays, and poorly sorted tills consisting of sand, silt, clay, and large boulders. Wet soils constituted 15 to 20 percent of the total area of the Range, and each of the different types of soil provided a suitable base for the melange of arriving individual species of trees. ${ }^{11}$ The well drained soils of the Range allowed for the establishment of sugar maple, yellow birch, elm, and basswood, with a smaller proportion of hemlock, balsam fir, and white pine. On the thinner and drier stony soils and rock knobs white pine, Norway pine, aspen, cedar, and oaks, with sugar maple, elm and yellow birch found suitable habitat. On the poorly drained soils, spruce, cedar ${ }^{12}$, tamarack (also referred to as larch) grew generally on the peats, while hemlock, white pine, elm, ash and aspen grew on the mucks. Hemlock, white pine, spruce, elm, ash, red maple and basswood were established on the mineral soils. ${ }^{13}$

The post Wisconsinan glaciation climate was not sedentary. The general retreat of the glaciers between 14,000 and 4,000 years ago was punctuated by readvances of glacial lobes. Between 10,000 and 8,000 years ago the area became warmer and more moist, favoring spruce and pine. After this period the climate progressively became drier, with oak and certain types of pine flourishing. South of the Marquette Range a prairie peninsula stretched from Iowa into Ohio allowing grassland and savanna conditions to exist over large areas of the Midwest and preventing the migration of trees northward. The climate again changed 3,500 years ago, becoming cooler and more moist, and again allowed deciduous trees to spread westward and northward. ${ }^{14}$ Later, the continuing climatic variation included the Little Ice Age, a period extending between the $15^{\text {th }}$ and mid- $19^{\text {th }}$ centuries of generally cooler and more moist climatic conditions, with greater 
frontal activity. The conditions of this period favored large stands of white pine and hemlock, 250 to 300 years old, and may have produced the large stands of these species which were viewed by early settlers as inexhaustible. ${ }^{15}$ Writing specifically of the white pine of the Marquette Range in the early 1880s an early settler named James E. Jopling stated that, "Forests covered most of the district, only a few relatively small areas had been cleared. (White) Pine trees stood among the hardwood or grew together in extensive groves, in fact it was often remarked that all the pine would not be cut in a life time yet most of it was cut in the next fifteen years." 16

\section{Early Human Impact on the Forest}

The impact of humans on the forests of the Marquette Range began with their initial arrival following the recession of glaciation. As the climate warmed, paleoindians tracking large species of game became more common in the area. The hunters employed Keweenawan copper and silicified sandstone to construct implements for their survival and also participated in the trade of native copper. ${ }^{17}$ The paleoindians and later the Anishnabeg had a definite influence on the forests of the Marquette Range. Selective logging for coppicing and clearing for cultivation combined with the use of fire by the Indians began the establishment of a cultural landscape in the area. The use of fire by Indians on the Range allowed the land to be cleared for cultivation, improved travel, hunting, and game habitat. ${ }^{18}$ Other Indian impacts included the hunting of large ungulate populations and beaver that reduced grazing and flooding of the lowlands. This loss of grazing and wetlands favored certain species of trees. ${ }^{19}$

Beginning in the 1840's, the arrival of European-Americans to the Marquette Range ushered in a period of profound transition to the forests of the Range. For much of the Upper Peninsula of Michigan the logging industry brought the first real civilization to the mostly wild forests. The industry provided essential building materials for the growth of American Civilization throughout the country, however, the logging period in this nation also witnessed the "destruction and deterioration of natural resources such as perhaps nowhere else been witnessed in so short a span of time." 20 The forests became a merchantable commodity and, coupled with America's extraordinary westward 
expansion, a very valuable one. The land was bought from the Indians, surveyed, and sold to Americans who began the extraction of the timber and a massive revision of the natural features of the land.

\section{The Survey of the Land}

The purchase of land from Native Americans through various treaties in the $18^{\text {th }}$ and $19^{\text {th }}$ centuries resulted in very large areas of Federal land. ${ }^{21}$ The Commissioner of Public Lands and the General Land Office had the responsibility to dispose of these lands in a way that would most benefit the country and maximize public settlement. However, before the land could be sold to settlers, a survey dividing the land into systematic, organized tracts of townships and ranges was necessary.

In Michigan, government surveyors began the work of bounding and delineating the land in $1815 .^{22}$ The initial task of the survey was to establish the accurate location of the baseline and prime meridian for the state from which individual townships could be laid off. Progressing outward from these initial lines, a grid system defined and delineated the land, with this grid system consisting of townships, 36 square miles in size with 36 one mile square sections contained within each township. Townships were numbered running east or west of the initial meridian, and north or south of the initial baseline, and within each township the sections were numbered one to 36 beginning in the northeast corner. By 1825, most of the southern third of the Lower Peninsula had been surveyed. The survey slowly completed its definition of the Lower Peninsula and by 1840 , the survey of the Upper Peninsula began. ${ }^{23}$ By the mid-1850's the survey of the entire state was complete.

The surveys were conducted by individuals under Federal contract with the Survey General. The task was to run a line exactly straight in a direction directly eastwest or north-south, and to measure that line in increments of one mile. Each survey employed two chain men whose task it was to measure the line, and an axe man to clear the line of brush and mark the corners of the sections by driving a hardwood stake into the ground. The head and assistant surveyors worked with a compass set on a tripod. The surveyors collected information concerning tree species and their diameters along 
section lines that provided a grid of transects with one mile spacing. The surveyors also took note of recently burned areas, windfalls, beaver impoundments, rivers and streams, wetlands, existing settlements, trails and roads, and the agricultural potential of the soils. Later, in the Upper Peninsula detailed notes on the geology of the area were recorded and samples of the rocks were taken to aid in the geological survey of the area. Douglass Houghton originated the idea of Federal Surveyors aiding the understaffed and under funded Michigan Geological Survey in the process of quantifying the geology of the state. For the work of the survey, surveyors received from two to six dollars per mile surveyed; for an eight month work year a surveyor could make $\$ 3000$, out of which he had to pay his assistants. ${ }^{24}$ From these surveys came some of the first detailed and organized written accounts of the Michigan wilderness. Figure $5^{25}$ is a map of historic vegetation on the Marquette Range reconstructed from General Land Office survey records. These records depict the general composition of the forest of the Marquette Range over an extended period, beginning roughly 3,000 years ago and ending with major European settlement. The data acts as a stable baseline of vegetation on the Range and can be used to evaluate change caused by humans.

Although these maps represent a highly detailed reconstruction of the forest of the pre-major settlement Marquette Range, they are limited in important ways. The surveys took account of the trees only along straight lines. Within Figure 5, and in several other figures in this chapter, this linear sampling has been applied to a planar surface. Because of this, as a two dimensional representation, the maps have inherent limitations, and can only be viewed as a general representation. The original, pre-settlement forest was in the words of J.O. Veatch: "characterized by a great number of separate species, intimately associated and in a great number of combinations with some species greatly restricted in frequency and range of occurrence, others common and ranging throughout the State (of Michigan); and because the data is so meager and fragmentary for some local areas... any reconstruction must be at best subject to doubt.,"26

From Figure 5, with the limitations of the representation in mind, we see that the diverse distribution of tree species that were present in the dense forest of the Marquette Range of the 1840's progressed generally in an east to west direction from large stands of 


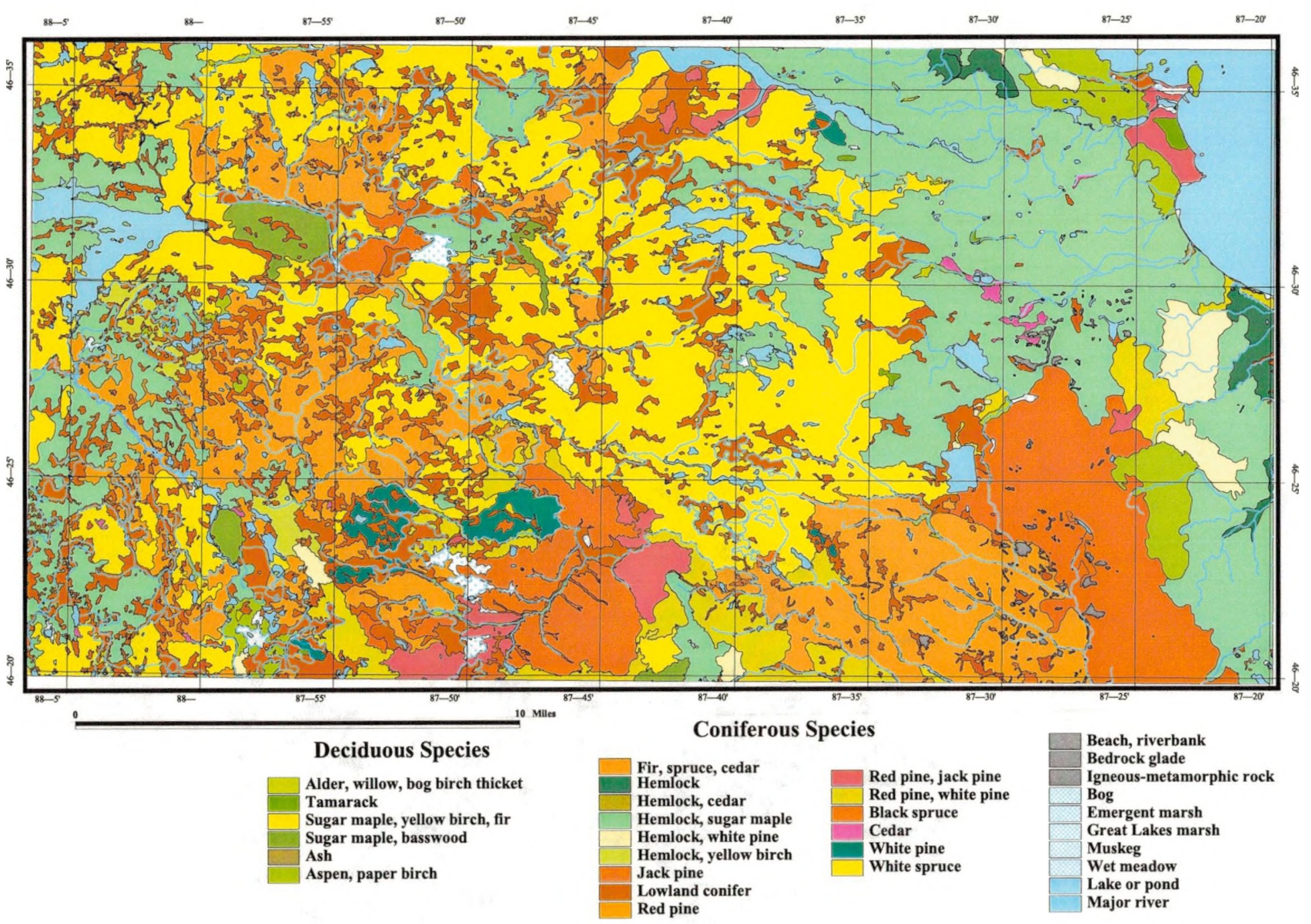

Figure 5. Historic Description of Forest on the Marquette Range From GLO Survey Notes ca. 1840's 
hemlock to sugar maple and yellow birch. In the southern part of the area jack pine was common, with pronounced stands of white and red pine. The sugar maple, yellow birch, and fir forest was dominant in the area of the Negaunee Iron Formation where later a majority of the mines and furnaces would be built, with hemlock forests becoming dominant again near Lake Michigamme in the western part of the area. It is important to note in this figure that the hydrology represented includes recent digital line graph data, and is as a result a representation of the present hydrological distribution, and not that of the 1840's. Although most of the features on a large scale have remained consistent, reservoirs have been constructed, often to produce the large amounts of water and electricity needed in iron mining, streams have been diverted, and wetlands have been drained. These features have been added to the map as landmarks to acclimate viewers to the pre-major settlement landscape.

Following the survey, the land of the Marquette Range was sold and resource extraction began. Logging of white pine and then later hardwoods on the Marquette Range, mostly for building materials, began in the early 1850 's and ran into the $20^{\text {th }}$ century. This logging resulted in the construction of several sawmills on the Range and was very influential in the removal of white pine and hemlock from the area. Logging on the Range was also closely associated with the iron production and mining of the area. This logging concentrated much more heavily on the hardwoods of the Range, favoring the cutting of sugar maple and yellow birch, and was the longest lasting and most influential of the timber industries of the Marquette Range.

\section{The Logging of the White Pine and Hemlock}

Throughout the early stages of the logging of timber in the Eastern United States, white pine was valued for its strength, purity and great height. ${ }^{27}$ The species produced durable boards and because the limbs of the tree started $3 / 4$ of the way up the trunk, the boards were essentially free of knots. Many loggers believed it to be the only species worth taking; white pine was sought after extensively and where it was found it was exhaustively harvested. ${ }^{28}$ Transportation has always been closely related to the economic viability of logging, and early in the country's history, because of their low 
cost of handling per unit value and high sale value, only larger trees of the best species such as white pine were logged; the high sale value justified the expense of transporting the timber to a market. ${ }^{29}$ White pine logging began heavily in the Lake Superior area beginning in the 1830s and reached a peak in the area between 1890 and 1910. After this all of the merchantable white pine had been cut or destroyed by fire. ${ }^{30}$

The species grew throughout the lake country in impressive, but usually very limited stands; their height dwarfed the hardwoods. Looking at Figure 6 we see that the distribution of white pine on the Range was limited to small patches in the south central part of the Range and just south of the Dead River (now a reservoir) in the north. However, these patches were impressive. James Jopling wrote of the patches: "From the tops of the Negaunee hills, one could see 'giant pines in every direction'. There were 'probably twenty other trees to one pine', but the pines were three, four, or even five feet in diameter." 31 W.D. Whitney stated of the trees in the early 1850s: "[N]owhere did we find it (the white pine) growing in great abundance, nowhere forming what would properly be called a fine forest. It rather appears in single trees, standing amid the mass of deciduous forest, and far overtopping it, or in little clumps of a dozen or two, on the crest of a ridge...(the pines attain) a diameter and height nearly as great as in its most noted localities." 32

The limited spatial distribution of the white pines determined the nature of the logging of the species during the short duration that it lasted. Many small firms, owning selective plots of land, clear cut the white pine stands, and then transported these pines to a market, with the transport of white pine facilitated by the tree's buoyancy in water. This was particularly important due to the small number of roads and railroads in the Lake Superior area in existence at the time. Stands of white pine were cut and transported by sleigh during the winter months to the rivers where they were stacked until after the spring thaw, and then floated downstream to sawmills at the outlets of the rivers. ${ }^{33}$ On the Marquette Range the Dead, Garlic, Chocolay and Escanaba Rivers were important for the transport of white pine timber to sawmills. The rivers, too narrow and filled with obstacles in their natural state to serve the purpose, were dammed to increase their flow and dynamited in places were tight bends or falls existed. ${ }^{34}$ The dams were 


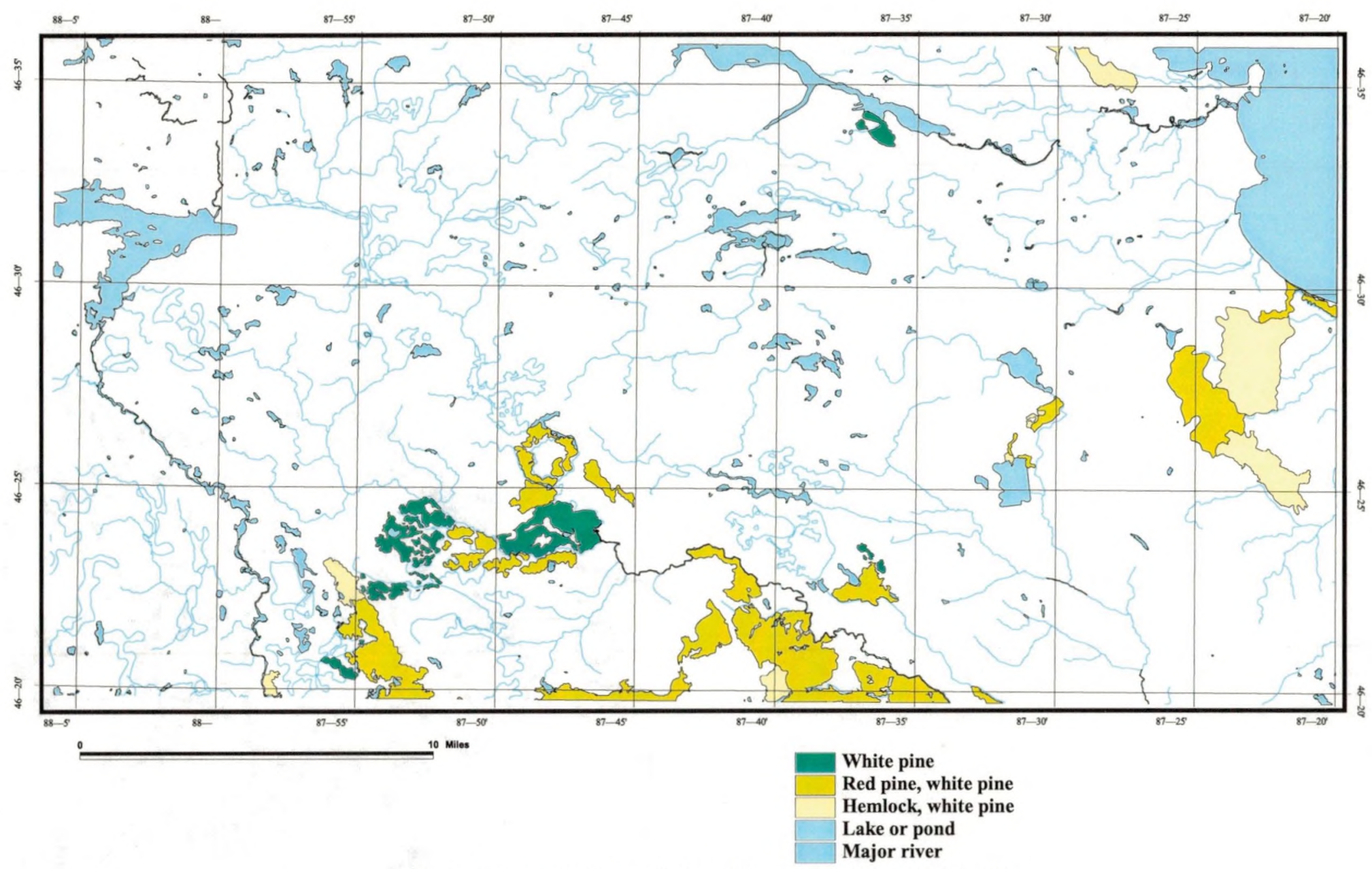

Figure 6. Historical Description of the Distribution of White Pine On the Marquette Range From GLO Survey Notes ca. 1840's 
usually constructed from nearby timber, but still represented a substantial cost to the operation. They were employed to hold back enough water so that the logs could float downstream when the inundation was released in one large flow. ${ }^{35}$ On the Dead River, throughout the second half of the $19^{\text {th }}$ century on the Range, extensive damming from Silver Lake down to its outlet and on the many streams and creeks flowing into the river greatly affected the surface hydrology of the area and its riparian ecology. The river was at times so cluttered with logs that the flow was reduced considerably. These periods of low flow were commonly augmented by times of extreme flow as happened during the year of 1891, when logging contractors, anxious to move their product while the Dead River was high, opened many of their dams and caused severe flooding downstream, damaging the mills located near Lake Superior. ${ }^{36}$

On the Marquette Range the milling of timber was quite common, and beginning in the early 1850's several saw mills were set up to supply the demand for local building materials. ${ }^{37}$ The early forges of the area also had saw mills attached to them to provide the wood needed in the iron bloomeries. Eagle Mills, built in 1851, an early example of the timber milling industry on the Range, was located about one mile east of the Carp River Forge along a primitive trail connecting the Jackson Mine and the early townsite of Marquette. The location of the mill is shown in Figure 9. In 1855 the Jackson and Cleveland mining companies began construction of a plank railroad that would be used to transport iron ore from the mines to Marquette. All of the building materials created from timber for the plank road, which passed very near Eagle Mills, were supplied by the mill. ${ }^{38}$ By the late $1860 \mathrm{~s}$, the mill consisted of one steam powered circular saw, along with a shingle mill and a planing mill, and employed between 50 and 75 men at nearby logging camps. The mill produced lumber, lath, flooring, siding and shingles, and had facilities for drying lumber. ${ }^{39}$ One contract of particular interest involved the production of hardwood rails for a small tram railroad between the Morgan Furnace and kilns near the Dead River. ${ }^{40}$ In 1874 the mill burned down but was rebuilt and by 1876 the mill was producing 16,000 board feet daily. Eagle Mills stayed in business until a lack of timber forced it to close in the early $20^{\text {th }}$ century. ${ }^{41}$ 
An early land agent in the area named Horatio Bigelow addressed the sawmill industry that would take advantage of the supply of the white pine of the Range when he wrote in 1864, concerning the value of the 33,000 acres of land on the Marquette Range transferred into the holdings of the St. Mary's Canal Mineral Land Company: " $\mathrm{Gr}$ "Good pines are...found scattered amongst the hard-wood groves and will supply sawmills., 43 Although the mills became a vital part of the economy of the Range, the increased consumption of logs at these mills was also associated with the rapid destruction of pines in the area. ${ }^{44}$ By 1895 , most of the virgin white pine of the Marquette Range had been cut. The Teal Lake Mill, constructed in 1881 at Negaunee on Teal Lake by the Johnson Lumber company, was built to take advantage of stands of white pine in the area, with a blacksmith shop and a boarding house also constructed at the site. White pine north of Teal Lake was logged by employees of this mill, hauled to Teal Lake and then rafted to the mill. This process was modified in 1892 when the Negaunee Town Council ruled that because Teal Lake was the city's source of drinking water, the mill could no longer bank their logs there. The mill opened a road north of the lake and continued to log the pine until shortages forced them to stop in $1895 .{ }^{45}$

Along with the logging of white pine, deciduous hemlock also began to be cut down for profit during the early history of major settlement on the Marquette Range. Hemlock grew with white pine and northern hardwoods in often dense stands of considerable age. Douglass Houghton noted the tree on his expedition of 1841 to the area stating: "With this timber (the sugar maple of the Marquette Range) is frequently intermixed oaks and large hemlocks, and extensive bodies of the latter timber occur; together with occasional pines." ${ }^{46}$ In Figure 7 the pre-major settlement distribution of hemlock on the Marquette Range is shown, with the majority of the stands near Lake Superior. Further west near Lake Michigamme there were also large numbers of hemlock. A shade tolerant species, the hemlock prefers to grow in areas under the canopy and on precipitous terrain and was present in such locations on the Range prior to large scale settlement.

During much of the early period of logging, the hemlock was viewed by most loggers as worthless. However, as time passed the species began to be viewed favorably 


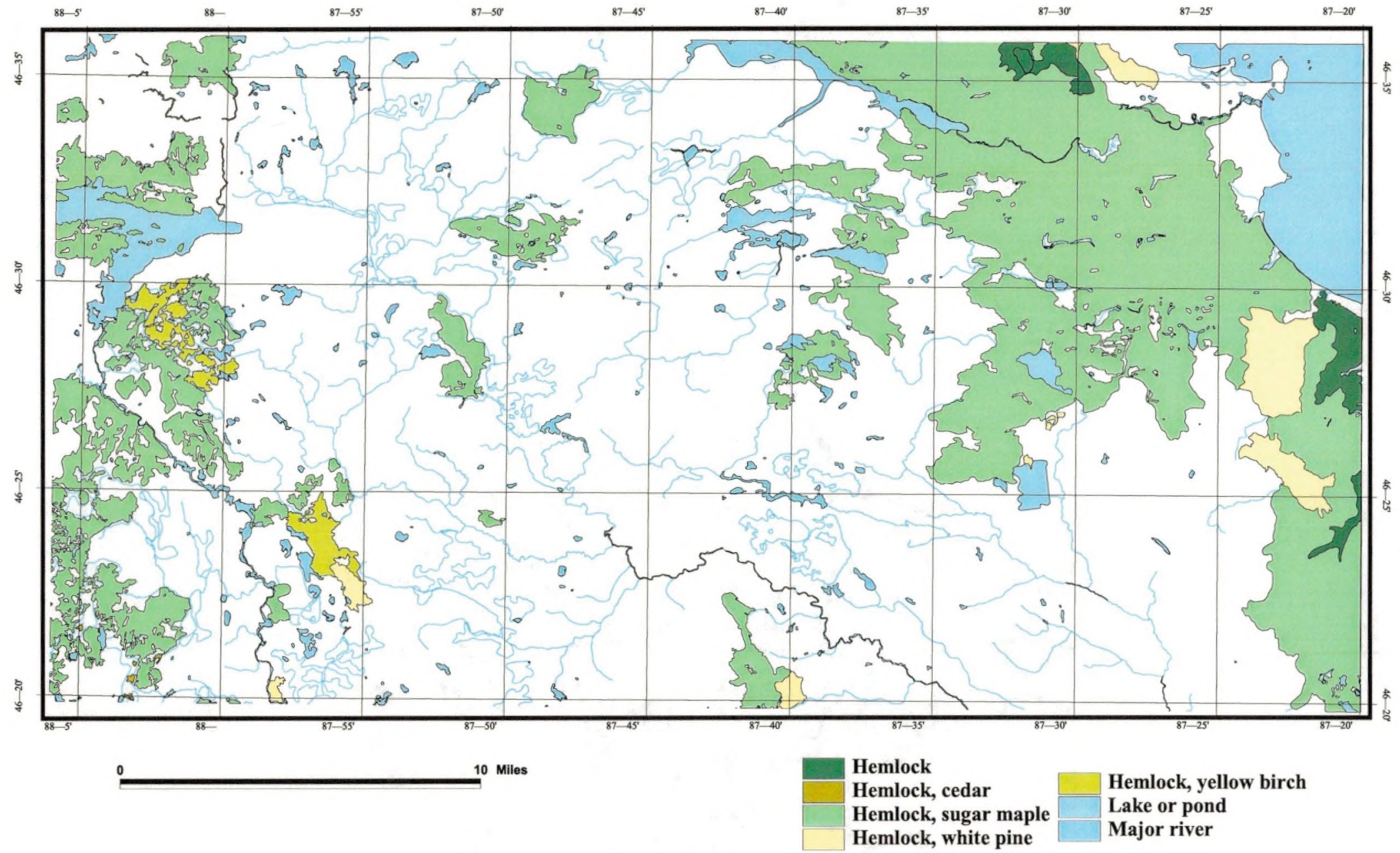

Figure 7. Historical Description of the Distribution of Hemlock On the Marquette Range From GLO Survey Notes ca. 1840's 


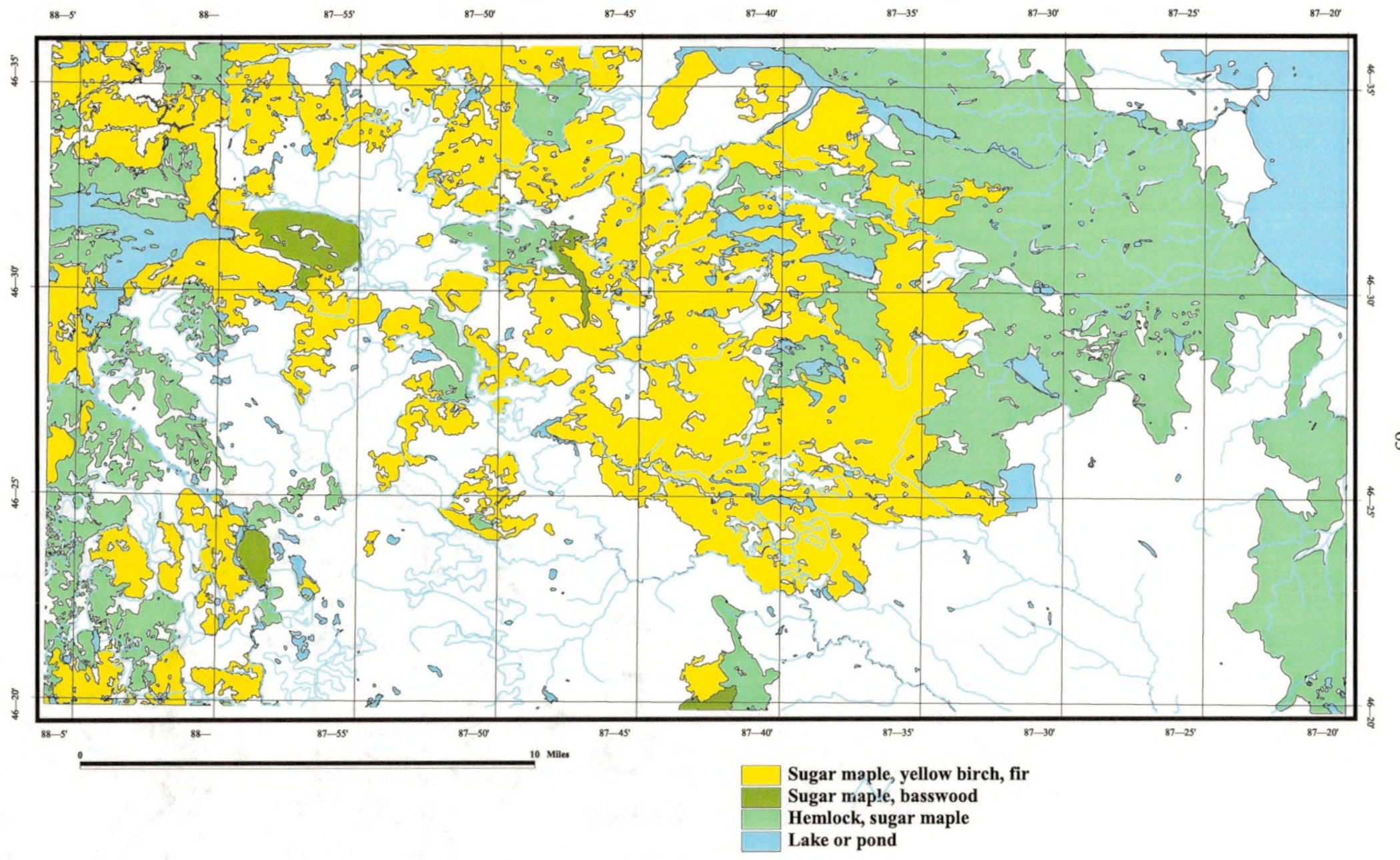

Figure 8. Historical Description of the Distribution of Sugar Maple On the Marquette Range From GLO Survey Notes ca. 1840's 
by loggers. Similar to the white pine, when the bark of the hemlock was removed the tree could be floated down river, facilitating the transportation of the species. Although the wood could be brittle, weak, course-grained and prone to splintering, it came to be utilized as railroad ties and mine timbers. The bark could be used to convert cow hides into leather and as tanneries spread westward, hemlock began to be a valuable commodity and was removed with rapidity. ${ }^{47}$

\section{Hardwood Logging and Iron Production}

As the supply of white pine in the Lake Superior area diminished, timber companies were forced to shift their focus to the logging of other species and began to cut down deciduous trees. The hardwoods were of a much lesser value than the white pine but were much more numerous, and because of this, the removal of hardwood witnessed land and capital consolidation and much larger scale logging operations. This affected the spatial distribution of land ownership and settlement patterns, with well financed companies able to purchase large areas containing hardwood timber, often at low prices. ${ }^{48}$ Because hardwood does not float, improvements in rail transportation were a necessary component of the logging and this led to infrastructure development throughout the Great Lakes area.

On the Marquette Range the logging of hardwoods was very closely related to the production of iron, so that the logging of deciduous trees here predated all other logging and produced something of an anomaly in the progression of species logging in the Great Lakes area. Hardwoods were valued on the Range because these species made the best charcoal for the smelting of iron. The timber most commonly used from the onset of iron production on the Range was sugar maple with yellow birch, hemlock and some softwoods used. According to A.P. Swineford, $4 / 5^{\text {th }}$ of the charcoal of the Range created in 1869 came from maple. ${ }^{49}$

Pig iron production on the Marquette Range that began with the construction of the Carp River Forge in 1847 and was a thriving industry by the 1860's was a cornerstone of the industrial development of the U.S. during the $19^{\text {th }}$ century. ${ }^{50}$ At the beginning of that century the iron industry in America was widely dispersed, and concentrated on the 
creation of implements for agriculture. By the beginning of the $20^{\text {th }}$ century the American iron industry was a global leader, an empire of iron and the coal used to smelt it. The iron integral to the rapid industrial development of the U.S. was used to fuel the movement westward and to thrust America onto the scene as a major world force. ${ }^{51}$

In 1775 the colonies of America provided approximately $1 / 7^{\text {th }}$ of the iron globally produced. $^{52}$ Iron mining and processing facilities existed in wide distribution from Massachusetts to Georgia with the manufacturing process using bog iron ore, a very low grade but widely available ore. The industry serviced mostly agricultural and commercial interests, and was a rural rather than urban industry. ${ }^{53}$ During the late $18^{\text {th }}$ century a shift was made in the global iron smelting industry from charcoal to the cheaper fuel of coke made from bituminous coal. This transition, begun in England, was slow to affect America; in 1847 only 1/4 ${ }^{\text {th }}$ of the iron smelted in the U.S. came from coke, with the remaining $3 / 4^{\text {ths }}$ coming from charcoal fired furnaces. Hesitancy to change was particularly acute in the Great Lakes area where charcoal furnaces lasted into the $20^{\text {th }}$ century. ${ }^{54}$ One reason for this continued reliance on hardwood to smelt iron in the U.S. came from the massive abundance and perceived inexhaustibility of timber in America. ${ }^{55}$ Also the early iron industry in America was greatly linked to transportation, which throughout its history in the U.S. has been closely linked to iron's economical production. Transportation improvements in the form of railroads and canals led in the 1830's to cities such as Pittsburgh and Chicago becoming centers of iron production. In the 1830's extensive and transportable fuel such as bituminous and anthracite coal began to be used in the processing of iron into pig iron, disrupting the monopoly of charcoal furnaces and slowly beginning the change to coke. ${ }^{56}$ However, processing facilities still existed in rural areas where extensive stands of hardwood forests necessary for creating charcoal to smelt the iron, water power, and iron deposits occurred in conjunction. ${ }^{57}$ In these areas transportation concerns centered only on shipping, usually by water, the finished pig iron to market.

Conditioned by the long history of pig iron production through smelting in charcoal furnaces, and aware of the large extent of hardwood forests and hydrological power in the area, the first settlers envisioned the Marquette Range to be a smelting 
center. This belief brought about the construction of four forges in the area, and a total of 25 blast furnaces on the Marquette Range, and built a thriving logging and smelting industry. The industry lasted into the $20^{\text {th }}$ century because of the large amount of hardwood present on the Range, and because iron created from charcoal was of a higher quality than iron produced from coke. The charcoal produced iron, free from the impurities of sulfur and phosphorus and higher in silicon content, was commonly used, before the advent of wide spread use of steel occurring in the 1890 's, in specialty items such as railroad car wheels and axles. ${ }^{58}$

\section{The Kilns of the Marquette Range}

Iron production involves the reduction of the iron oxide to an alloy of iron and carbon known as pig iron. The early forges and later blast furnaces of the Marquette Range supplied very high temperatures which allowed the oxygen in the iron oxide to combine with carbon monoxide from the carbon source, provided by the charcoal, to form the pig iron and carbon dioxide. Charcoal provided the intense heat required to melt the iron ore and was also free of sulfur and phosphorous. ${ }^{59}$ Charcoal's purity made it an ideal source of carbon, with its drawbacks as a fuel involving the large amount of labor, skill and time involved in its acquisition, production, and transportation performed by woodcutters, colliers and teamsters. ${ }^{60}$ The hardwood was cut down and then processed in large earthen structures that, because of their distinct shape, were referred to as beehive kilns. The wood was slowly burnt in a low oxygen environment free of volatile gases and water and the result was a carbon enriched residue known as charcoal. ${ }^{61}$ Discussing the process J.W. Foster's work from 1865 stated that, "Firm, hard, shining charcoal is the result of high heat and the exclusion of moisture and air. Low heat, vapors and air produce a soft, friable coal. The difference whether coal is charred slowly or rapidly is great. The process should be slow at first and the heat should not rise above 270 degrees F. When the water is expelled the heat may be raised."62 In the making of charcoal unsound wood resulted in weak coal and could spontaneously combust; only quality wood could be used. A good collier could make 40 bushels of charcoal from one cord of 
wood. The wood was usually cut in the winter and charred in the summer because coal charred in the winter or during stormy weather was always poor and the yield small. ${ }^{63}$

On a field trip looking at the Early Proterozoic stratigraphy of the Marquette Range during the $45^{\text {th }}$ Institute for Lake Superior Geology Conference held in May of 1999, my advisor John Anderton and I located several ruins of beehive kilns in a wooded tract of land near Clarksburg in the western part of the Range. The field trip had made a stop to look at an outcrop of the Clarksburg Volcanic Member in the Michigamme Formation in a cut of an abandoned railroad grade near a pile of stones which was all that remained of the Clarksburg Furnace, and informed of the presence of these structures we ignored the outcrop and drove a mile down the road to visit the kilns. Although they dated from the past century and were ruins of an era long past, they were very easy to spot, the very large rings of their bases present in a thin second growth of hardwood saplings. Four of the former structures stood in a row, present on a flat stretch of ground near a stream. On one side of the kilns was an abrupt embankment which stood at the same height as that of the kilns prior to their degradation; one could imagine the planks that spanned the space between the hill and the tops of the kilns providing access to the slowly burning fires. All of the kilns save one had crumbled completely down to their circular bases, consisting of small piles of rubble roughly three feet off the ground, perhaps 25 feet in diameter. One kiln, however, still partially stood, with the amazing stonework of the arch of the doorway into the kiln telling of the fine masonry found in so many of the architectural sites of the Range. The domal structure, perhaps with a quarter of its original masonry still intact, was surprisingly large, and it was difficult to fathom the amount of wood which could be stacked in such a large structure.

These large earthen beehive kilns, constructed of heavy stone, were the main source of charcoal on the Range. Hundreds of the permanent structures dotted the landscape of the Range, spread out over the entire country and located where timber was plentiful. Each company that owned a furnace also owned large numbers of kilns to supply the furnaces with charcoal. In 1873 the Pioneer Furnace had 54 kilns in operation, with the Bancroft operating 20 kilns. The Morgan Furnace had 29 kilns, the Champion Furnace had 12 kilns, and the Greenwood and Michigan Furnaces operated 40 kilns. The 
Deer Lake Furnace had 20 kilns, while the Collins operated 16 kilns. ${ }^{64}$ Charcoal pits were also used to create the fuel, however, the pits were not as efficient as the kilns. A third type of charcoal manufacture, the movable kiln, was invented by the man who was in charge of the construction of the Soo Locks, Charles T. Harvey. This kiln was employed by the Northern Iron Furnace, which operated 26 of the kilns. The moveable kilns were conical in shape, the exterior consisting of sheet-iron somewhat thinner than a boiler plate and held together with rivets with screw heads. The joints of the kiln were lined with firebrick and numerous apertures with doors were present that allowed for the regulation of draft into the fire. Sixty cords of wood could fit into the movable kiln with the yield of charcoal generally ten percent of the wood originally put in. J.W. Foster addressed the main advantage of this type of kiln, stating that "as the country becomes stripped of its forests, it may be taken down, and set up in another place, with little expense." 65 Despite this great advantage the beehive kilns were the predominant method of charcoal production on the Range.

\section{The Distribution of Sugar Maple and Yellow Birch on the Marquette Range}

On the Marquette Range iron producers had a remarkable selection of hardwoods with which to smelt the iron. When Douglass Houghton saw the Marquette Range in 1841 he commented: "The broad and gently undulating valleys, described as occupying the intervening spaces between these ranges of rocky knobs, have in general a soil of dark, rich, and deep loam, and in many places are covered with large bodies of sugar maples of unusual size." ${ }^{\prime 66}$ Of the 33,000 acres of the St. Mary's Canal Company's lands in Marquette County Horatio Bigelow remarked: "all the company's lands... are covered with dense forests of yellow birch and maple." ${ }^{67}$ W. D. Whitney remarked of the very important sugar maple in 1851:

The first four maples (striped, mountain, sugar, and red) are very generally distributed throughout the lake country, and may often be found within the space of a few square rods. Yet in some quarters the sugar maple is altogether wanting, and its place is supplied by an abundant growth of red (pine). It is thus at Mackinac and in the vicinity of Copper Harbor. Of the four, the sugar maple...is by far the most useful and important. In the almost total absence of oaks and hickories, it is the sole dependence of the 
settlers for hardwood fuel, and for charcoal. As furnishing the latter article, and of the first quality, it is especially indispensable in the iron region (the Marquette Range); and, fortunately, it is nowhere found more abundantly, or of larger or finer growth. ${ }^{68}$

From Figure 8, it can be seen that the sugar maple was the most widely distributed tree species on the Marquette Range prior to major settlement. Its distribution covered much of the Range between what would later be the population centers of Marquette and Negaunee/Ishpeming, with the largest distribution of sugar maple and yellow birch similar to the largest distribution of the Negaunee Iron Formation. This combination of large iron reserves and extensive stands of a tree well adapted to the making of charcoal combined to heavily influence the human settlement of the area. In 1865, J.W. Foster wrote, "I have nowhere seen the maple attain such proportions as here, and its value for charcoal cannot be over-estimated." 69

\section{The Charcoal Bloomeries}

Following major settlement of the area, locally intense logging of hardwoods was linked closely to iron production that began on the Marquette Range with the construction of four primitive Catalan forges, or charcoal bloomeries, in the mid-1840's through early 1850's. The first of these bloomeries was the Carp River Forge located two miles east of Negaunee. The location of the forge was fairly near the iron formation, close to large stands of sugar maple and uniquely situated where a river cut through the Ajibik Quartzite, providing a location for the construction of a dam. During the summer of 1846 , only two years after the initial discovery of iron in the region, the Jackson Mining company decided to build a smelting operation to convert the iron ore they were mining into marketable iron. ${ }^{70}$ Habitation and a forge were built on the Carp River, approximately three miles east of their mining operation in section one, Township $47 \mathrm{~N}$., Range $27 \mathrm{~W}$., and before winter set in they had cleared both sides of the Carp at the location, built a sawmill and houses, improved the trail to Lake Superior and performed more work at the mine. ${ }^{71}$ Plans were made for a dam across the Carp and the construction of the forge. In July of 1847 Ariel Barney, experienced in iron production, 
arrived with components of the forge and took over the operation. ${ }^{72}$ During that summer, two cold-blast bloomeries and an eighteen foot high dam across the Carp were constructed. Smelting did not occur until the winter of the next year with 24 men and two women staying the winter on the site. February 10, 1848 the first iron was smelted at the Carp River Forge. ${ }^{73}$ In April of the year a flood washed away a part of the dam, but it was rebuilt and by 1849 the forge was producing two tons of iron per day. ${ }^{74}$ In 1851 the forge was converted from cold to hot blast, and by this time the forge had undergone numerous changes of ownership. ${ }^{75}$ An account from the Lake Superior Journal in 1851 describes the processes of the hot blast charcoal bloomery in detail:

The ore is first thrown into a large kiln, on a layer of wood, and burned for several days, being rendered by this process brittle. It is then taken to the stamps and pounded quite fine, in which state it is ready for the fire. The furnaces are something like a blacksmith's fire, on a large scale, being open in front and back, enclosed on the sides and tops with heavy cast iron plates, receiving the hot blast on either side. The finely pound ore together with the charcoal is thrown upon the fires in small quantities at a time, in their proper proportions; and after being subjected to this constant heat for three or four hours, the hot air is shut off, and the bulky shapeless of burning iron, streaming with melted earth substance, is pried out of the fire by the modern Vulcans, and tumbled along to the huge hammer. This mass, weighing about 300 pounds, will not melt with all the heat that can be applied to it under these circumstances; it is of too good quality for that; only poor article of iron ore is melted into making it into iron; but the foreign matter becomes liquid and collects in and at the bottom of the mass, and is run off in cinders from time to time during the process of the heating, and is perfectly driven out under the heavy hammer. It is quite surprising to see how easily a mass of this size can be handled by a bloomer, with his heavy tongs. By balancing the tongs firmly gripping the iron in a loop of suspended chain, he turns it and moves it backwards and forwards with all the precision and ease with which a blacksmith handles a common bar of iron. One of the blooms when finished weighs about 240 pounds, and on account of its unwieldy size and weight, it is sometimes cut into two pieces, being about two feet long, and four inches square. In this shape they are sent to market, ready for the rolling mill. ${ }^{76}$

All of the ore smelted at the Carp River Forge came from the Jackson Mine. In fact, the Jackson Mine supplied all of the four forges on the Range while they lasted. ${ }^{77}$ Ore from the mine was transported by horse or mule drawn carts on an early wagon road to the forge three miles away; during the winter months the ore was transported in a 
sleigh. The extraction operation was a simple one in the early stages of development. The anomalous specular and red hematite ore was resistant as compared with all but the metadiabase rocks surrounding it and in many cases outcropped at topographic highpoints on the Range. The mining was a quarrying operation where miners broke the hematite away from its outcrop and then broke the ore into smaller pieces. Due to the rugged nature of the land from the forge to the shore of Lake Superior, roughly eleven miles away, transportation was limited. With the transportation problems, and a lack of proximate charcoal sources the forge never realized a profit. A lack of charcoal was a problem that would be of issue for all iron production on the Range. The early forges required a very large amount of charcoal, approximately 200 bushels (one bushel equaling 20 pounds), to produce one ton of iron blooms. ${ }^{78}$ Kept in operation until 1854 , the Carp River Forge was abandoned as technological improvements changed the nature of processing on the Range, and the blast furnaces were built.

The second forge on the Range was built just south of the town of Marquette in 1849 by the Marquette Iron Company. At its height of operation the bloomery employed a total of 70 men, utilizing oxen and nine five-horse teams to haul ore, iron and charcoal. ${ }^{79}$ Sleighs were also utilized to transport the ore to the forge. The forge was destroyed by fire during the winter of 1850 and never rebuilt. ${ }^{80}$ The other two forge operations were constructed at Forestville and Collinsville, but these also failed to be economical in their operation. ${ }^{81}$ The first of these, the Buckeye Forge, was built in the fall of 1853, four miles upstream from Lake Superior on the Dead River. ${ }^{82}$ The Collins Forge, first producing iron blooms in 1855, was also built on the Dead River, two miles downstream from the Buckeye Forge. In 1857 this forge ceased operations and converted to a blast furnace located at the same site. ${ }^{83}$ Lewis Henry Morgan ${ }^{84}$ wrote in 1855 : "There are four forges in operation... The quantity of charcoal required for these fires is perfectly enormous, each fire requires 200 bushels per day. The four fires make four tons of iron per day and consume 800 bushels of charcoal." Morgan went on to address the future of iron production in the area. "There is no coal here near the iron mines now in the whole superior district. They must therefore either make it with charcoal or transport the ore to over in Pennsylvania near the coal beds or bring the coal here at a great 
expense. This will always be a great hindrance to the iron business but each year will diminish it. For the present the charcoal will answer." ${ }^{, 5}$

\section{The Blast Furnaces}

Beginning in the late 1850 s, iron production grew considerably with the construction of numerous blast furnaces on the Range. These furnaces were towering works of stone, 45 feet high, that when in production ran 24 hours a day, belching smoke from their incredibly hot fires. The furnaces became a vital part of the economy of the Marquette Range, collectively employing over 1000 men by $1873 .^{86}$ The first blast furnace on the Range was the Pioneer Furnace completed in downtown Negaunee in February of 1858, and by 1869,13 furnaces were in blast. ${ }^{87}$ Only one furnace in the district, the Marquette Furnace, used bituminous coal shipped, at the great expense Morgan referred to, from the lower Great Lakes. The rest received charcoal from the kilns of the district to smelt the iron. ${ }^{88}$ All of the furnaces were hot blast and propelled by steam or, in a few cases, water power. Of these 13 furnaces the Deer Lake, Morgan, Greenwood, and Champion furnaces were built in locations near a steep embankment where the top of the furnace, roughly 40 feet high, was at the same level as the embankment. ${ }^{89}$ The iron ore, the charcoal, and a limestone flux (an average of $70 \mathrm{lbs}$. of limestone flux was needed per ton of iron produced) were inserted into the furnace mouth at the top of the stack and at these locations a plank was constructed from the embankment to the mouth to facilitate the blast. At the rest of the furnaces steam hoists were constructed to raise the raw material to the top of the furnace. The temperatures of the blast furnaces reached between 450 and 650 degrees Fahrenheit with air forced into the furnace from two 3 to 4 inch tuyeres. ${ }^{90}$

The forges and the furnaces of the Marquette Range, the partial distribution of which is shown in Figure 9, caused rapid depletion of the hardwoods near them. Figure 9, which shows the location of six of the furnaces in blast in 1870, also shows the location of some of the kilns and mines of the Range, as well as the roads and railroads. By the late 1870 's, C. Rominger commented on the rapid depletion of hardwoods in his report of the geology of the Range stating: "The district... once heavily timbered,...(has) been pretty 


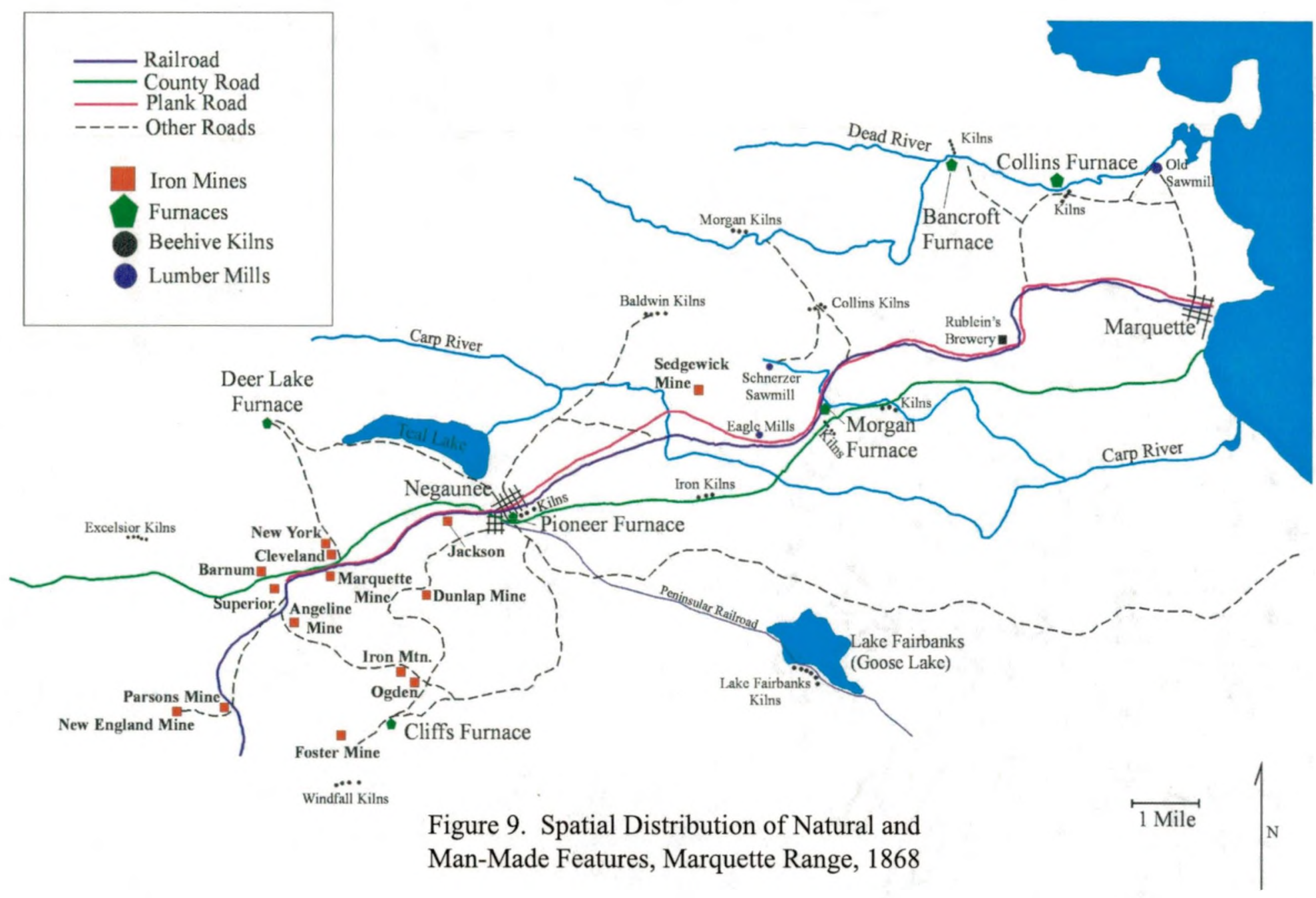


well cleared off in the vicinity of the mines and furnaces."91 The conversion of the virgin forest into useless cut-over progressed at an alarmingly quick pace. In 1869 the Pioneer Furnace produced 9,500 tons of pig iron. Its low efficiency of 5.5 cords of wood cut per ton of pig iron necessitated that 1500 acres be cut to supply the furnace for that year. ${ }^{92}$ William Gwinn Mather ${ }^{93}$ estimated in 1902 that over 160,000 acres of woodland had been cut to supply the two million tons of charcoal pig iron produced in the Upper Peninsula up to that point. Mather used an efficient figure of 2.5 cords of wood for every ton of charcoal iron made, to calculate his total of 10,000 acres of woodland cleared per year and 30 acres cut per day. ${ }^{94}$ This large demand for timber made it obligatory that the owners of the furnaces also own large tracts of land, which greatly affected the spatial distribution of property ownership on the Marquette Range. The Iron Cliffs company, later to become Cleveland Cliffs Iron (CCI) after merging with the Cleveland Mining Company on May 7, 1891, owned 42,000 acres of land in Marquette County. A large percentage of this land, at least 33,000, was acquired from the St. Mary's Canal and Mineral Land Company; the location of this property is shown in Figure $13 .{ }^{95}$ The Iron Cliffs Company operated the Cliffs and Pioneer furnaces. The Michigan Iron Company, operating the Michigan and Greenwood Furnaces, owned 20,000 acres of land in $1873 .{ }^{96}$ In 1873 the Morgan Furnace, which also operated the Champion Furnace, owned 20,000 acres of land, with the Deer Lake Furnace owning 5,500 acres. ${ }^{97}$

The forest of the Marquette Range could simply not keep up with the demand for wood and the kilns were consistently built further and further away from the furnaces. A decrease in the amount of proximate wood and the cost of hauling charcoal over the rugged terrain of the Marquette Range from areas progressively further away were significant factors in the closure of many furnaces. ${ }^{98}$ Until 1870 most of the charcoal was produced within two to five miles of the furnaces. ${ }^{99}$ Hauling costs for greater distances were prohibitive in an industry where large profits were uncommon. The Morgan Furnace, built in 1863 , was one of the most efficient furnaces on the Range. ${ }^{100}$ Located just east of the Carp River Forge, eight miles west of Marquette, the furnace exhausted the nearby timber supply by 1869 . At this point the furnace began acquiring its wood from land north of the Dead River, six miles from the furnace. To solve the problem of 
the distance a wooden railroad or tramway from the furnace to the stands of hardwood was built and twenty-four new kilns were constructed on the Dead River to supply the charcoal. ${ }^{101}$ Figure 10, a detail of a map constructed by T.B. Brooks in 1873, shows the location of most of this line from the Morgan Furnace to north of the Dead River. The figure also shows the location of several furnaces including the Bancroft, Collins, Grace, Carp River, and Pioneer Furnaces and the sawmills of Eagle, Harlow and Powder mills. The iron produced at the Morgan Furnace became an important source of iron for the Union cause during the Civil War, with the war in general being a positive influence on iron production on the Range. ${ }^{102}$ Many mines opened at this time and the price of pig iron per ton went from 45 dollars a ton in October of 1863 to 75 dollars per ton in August of $1864 .^{103}$

The timber was the most prohibitive and expensive part of the smelting process. The cost of charcoal consumed a full one half of the total cost of pig iron produced, with the iron ore costing a fourth and the largest part of the remaining fourth addressing furnace labor and superintendence. ${ }^{104}$ The iron business necessitated a large influx of capital and was a precarious industry. C.A. Trowbridge addressed this issue in a letter dating from 1868, stating, “...I had one experience in trying to run an iron works without cash capital after my works were completed and that was the only cause why the Collins (Furnace) came so close to ruin and I do not care to try it again or advise anyone to do so...Mr. Blair's talk about $\$ 3000$ or even $\$ 10,000$ to put his old Furnace in working shape is simply child's twaddle it can't be did...plenty of capital carefully and economically handled, will make money in the iron business and without it you wear yourself out and some keen fellow with 'the stamps' gets your furnace and all of your property for a song...,"105

\section{Logging Associated with Shaft Mining}

Another important influence on the forests of the Marquette Range was the logging that was done to provide supports for the underground mines of the Range. As the surficial iron ore deposits of the Range were exhausted several operations tentatively began digging beneath the surface for the ore. It was an expensive and dangerous 


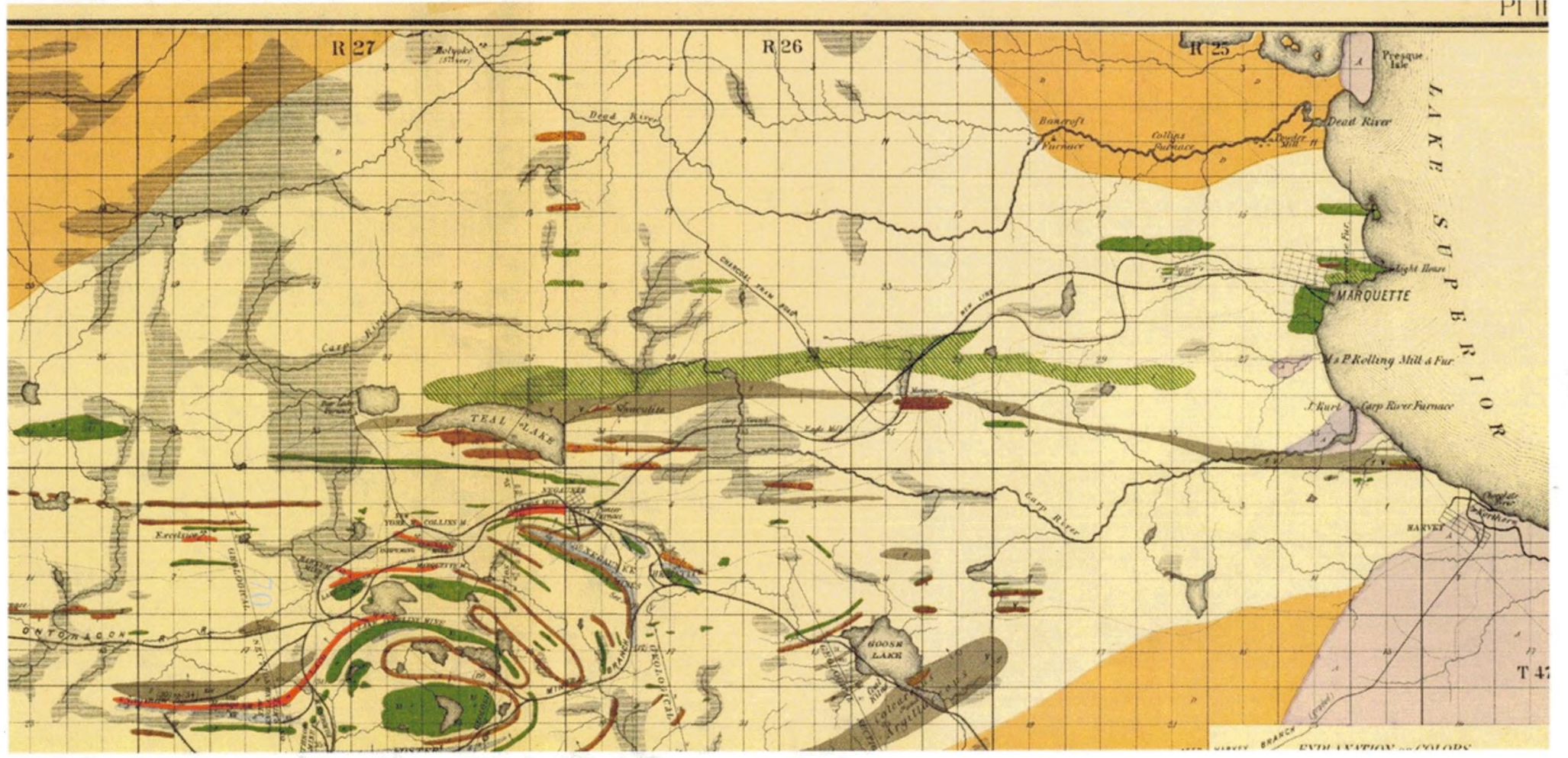

Figure 10. Location of the Charcoal Tram Road

From the Morgan Furnace to North of the Dead River 
business and only the highly skilled and well financed companies could participate in the project. Often drilling was performed to locate the ore bodies before a shaft was sunk. As shaft mining became a necessity, consolidation of capital occurred and the numerous and widely varied companies of the 1870 's gave way to large and wealthy mining companies. One of the many costly aspects of shaft mining was the intense logging that had to occur to supply supports for the underground tunnels. Large land holdings became a necessity for the mining operations, again affecting property distribution on the Range.

Until the first shafts were dropped into the ground the relationship between logging and mining was an indirect relationship. The timber was needed for smelting, but in the actual mining the forest only served as a hindrance, obscuring surface deposits of ore. With the underground operations the relationship became a direct one. ${ }^{106}$ A great deal of timber was used to support the underground shafts. Wood was the only material to be used in the mines because the supports had to be strong enough to hold the weight, yet able to yield enough to give gradually with the shifting of the undeniable overburden. ${ }^{107}$ Between 0.72 and 0.92 cubic feet of timber was needed per ton of ore extracted ${ }^{108}$ and some of the logs used in support were up to four feet in diameter. ${ }^{109}$ These thick logs were set up at short and regular intervals in the adits, drifts, and rooms of the mines with very heavy and thick boards laid upon them to support the roof and walls. The process of using square sets consumed a particularly large amount of timber, with the structures beneath the surface sometimes reaching 100 feet in height, built up through the ore with heavy timbers stacked upon each other. "The log and timber pile outside the shaft looked almost as big as the stockpile of ore, and the quantities going down on the skip seemed as great as the ore loads coming up." 110 In the low oxygen atmosphere of the mines the timber did not last long. A lack of sunlight and an extremely variable moisture content also reduced the life of the wood. The supports had to consistently be removed and replaced as the wood in the mine rotted. ${ }^{111}$ Although preservatives were used in some cases to prolong the life of the timber, the treated wood still had to be replaced every four to six years. ${ }^{112}$ Untreated wood, much more commonly used in the mines of the Range, had to be replaced every one or two years. Certain types of wood lasted better in certain types of environments within the shafts. Generally, hardwoods were best used in the damp areas 
of the mines, while softwoods worked best in dry areas. Birch lasted two to three times longer in wet workings than in dry, with hemlock rotting quickly, and tamarack lasting longer in wet places. ${ }^{113}$

\section{Conclusion}

The deforestation of the Marquette Range by European-American settlers in the second half of the $19^{\text {th }}$ century was one of the most important changes in the area and was a major defining factor in the history of the Range. The forests, coupled with iron ore sustained an extractive economy on the Range, and this economy allowed for, and in large part defined, the large scale settlement of the area. The iron production industry was the most influential force behind deforestation on the Range. It is estimated that by 1903, thirty acres of hardwood per day was needed to supply the kilns of the Marquette Range. ${ }^{114}$ One acre of wood was traded for 14 tons of iron. In the first half century of iron production 160,000 acres were cut to produce iron in an area mostly on the Marquette Range, and even considering that this is a conservative estimate we arrive at an area covering 250 square miles clear-cut for iron production. ${ }^{115}$

The effects of logging on the land were far reaching and extreme. Because of their value, white pine and hemlock were wholly removed. ${ }^{116}$ Hardwood logging also left few trees standing with very few logging companies participating in sustainable selective cutting. This logging opened up the canopy and created a new microclimate and habitat that favored rapidly growing, short lived, shade intolerant species that reproduced aggressively. ${ }^{117}$ These species, such as aspen, birch, and cherry, produced large numbers of light, wind dispersed seeds that allowed them to exploit the site's disturbed conditions. The second growth forest was dense and even aged, further affecting the nature of regeneration. Hemlock in particular, a species sensitive to direct sunlight, could not regenerate in the second growth conditions, and became known as a species that "could not endure civilization." 118

Fire was common in both the pine and hardwood eras, resulting in large areas of devastated terrain. Locomotives integral to logging during the hardwood phase created many fires. ${ }^{119}$ Fire burned an estimated 20 percent of the original 380 billion board feet 
of saw timber in Michigan and was also quite damaging in its effect upon the future status of the stands, destroying the seedlings leading to regeneration. ${ }^{120}$ The large amounts of fuel left behind as refuse by the lumbering process added to the frequency and intensity of the fires. ${ }^{121}$ The cutover and burned lands were often initially claimed to be productive for agriculture or pasturage, however, very few of the sandy and burned stump pastures were ever productive for such purposes. Regeneration of the forests did occur, but repeated logging and fires led to soil degradation. ${ }^{122}$

Figure $11^{123}$ shows a map of the spatial distribution of tree species on the Marquette Range in 1990. This map shows graphically how much the forests of the Marquette Range were modified by major settlement. Compared with Figure 5, the most obvious change brought about by large scale settlement of the region is the loss of trees. Shown in gray, non-forested open spaces have become a dominant characteristic of the Range, where as they were barely existent in the 1840's. This open space is extensive even after second growth has occurred over much of the area and was even more extensive earlier in the century. The figure shows that the composition of the forest has changed considerably with Aspen and birch as much more prevalent species, and oak and hickory present in an area where they had not existed prior to settlement. Although the maple and birch are still present in great numbers their location of dominance has been radically changed. The diversity of tree species on the Range has been greatly reduced.

The effects of logging reached beyond the trees. Edge-dwelling animal species were reduced by the forest's removal and where the trees were clear-cut the landscape became hotter in the summer and colder in the winter, with temperatures fluctuating more widely. Snow melted more quickly and the ground froze more deeply. The capacity of the soil to hold water decreased and with it runoff became increasingly less predictable. The groundwater table fell. ${ }^{124}$ The matrix of cutover and second growth woodland that came into existence following the era of intensive logging on the Marquette Range was defined by the natural features present after logging, and in other cases by the settlers actively taking part in the replacement. Though agriculture never flourished, deforestation led to civilization, and a cultural landscape emerged from the stumps and 


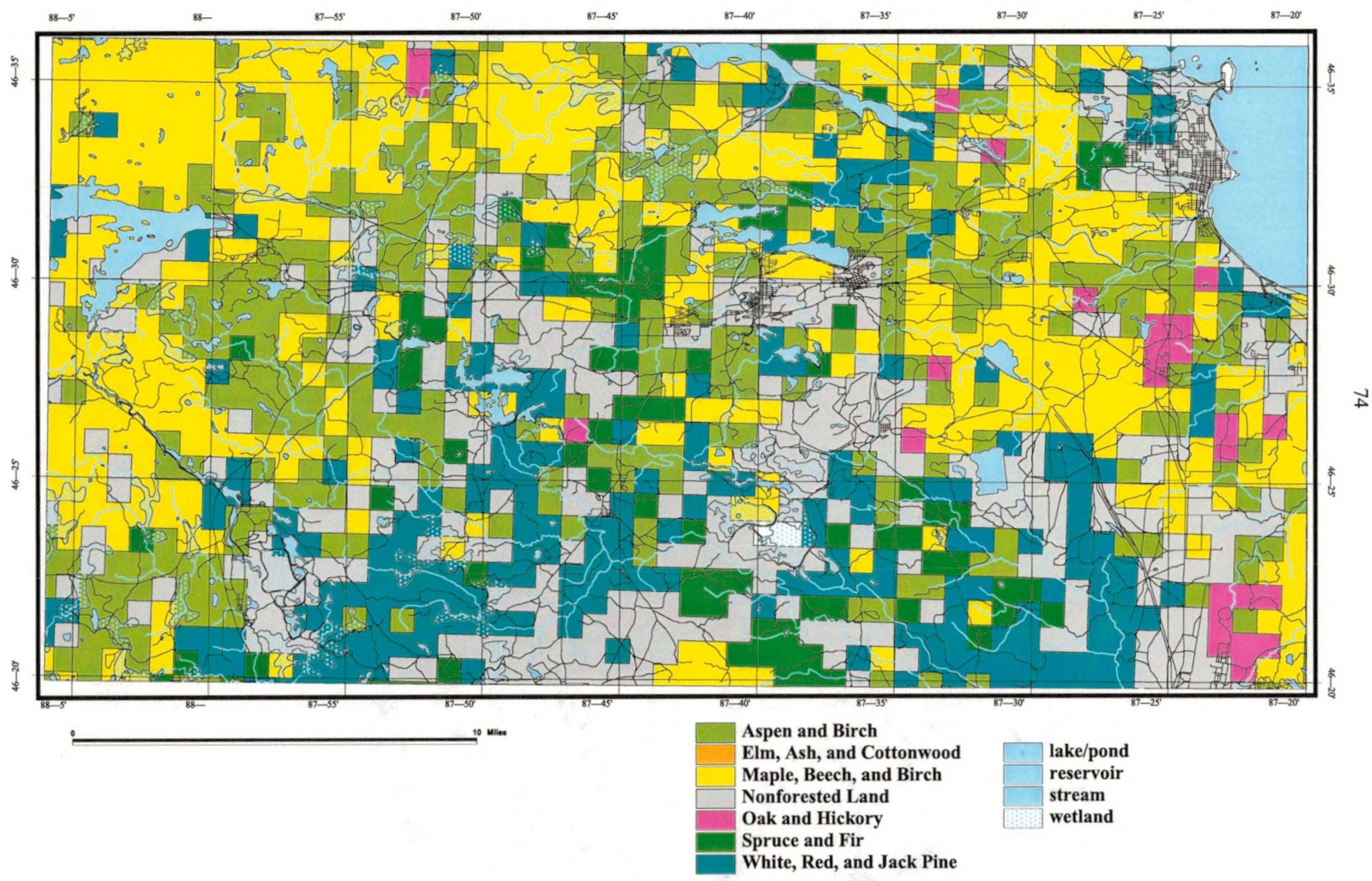

Figure 11. Distribution of Forest on the Marquette Range, 1990 
ashes of the Range. A radically different mosaic of ecological habitats emerged and the wilderness was tamed. 


\section{END NOTES}

${ }^{1}$ Stearns, Forest W. 1997. History of the Lake States Forests: Natural and Human Impacts. In: Vasievich, J. Michael; Webster, Henry H., editors. Lake States Regional Forest Resource Assessment: Technical Papers. Gen. Tech. Rep. NC-189. U.S. Department of Agriculture, Forest Service, North Central Forest Experiment Station. St Paul, MN. p. 2 Located at the Great Lakes Ecological Assessment web site at http://econ.usfs.msu.edu/gla/reports/physical.htm (all page numbers coincide with the web site)

2 Ibid., p.2

3 Ibid., p.4

${ }^{4}$ Boyum, Burton H. 1991. Chapter 3: Iron Making. In: Mulligan, William H., editor and contributor. Historical Resources of the Iron Range of Marquette County, Michigan, 1844-1941. The Economic Development Corporation of the County of Marquette. p. C15.

${ }^{5}$ Foster, J.W. 1865. Geology and Metallurgy of the Iron Ore of Lake Superior: Being a Report Addressed to the Board of Directors of the Iron Cliffs Company. Bryant and co. Printers, New York p. 65 and Brooks, T.B. 1873. Plate VIII. Furnaces Consuming L.S. Ores, Production of Pig Iron, Metallurgical and Chemical Character of Ores in Brooks, T.B. 1873 Iron Bearing Rocks of the Upper Peninsula of Michigan. Michigan Geological Survey Report 1869-1873. Two Volumes. Julius Bien, New York.

${ }^{6}$ Stearns, Lake States Forests, 1997, p.2

${ }^{7}$ Ibid., p. 2

${ }^{8}$ Ibid., p.2

${ }^{9}$ Ibid., p. 3

${ }^{10}$ Ibid., p.3 The dates for the arrival of the trees are stated by Stearns to come from the pollen record, and charcoal, wood, snail shells deposited in bogs and lakes. Varves were also used, as well as sediment layers in rivers to provide data on periods of heavy rainfall and flooding. Recent fluctuations in the climate interpreted from records of ocean ice, plant disease epidemics, movement of mountain glaciers and tree rings.

${ }^{11}$ Veatch, J.O. 1928. Michigan Quarterly Bulletin, Michigan State College of Agricultural and Applied Science, p. 124-25 This is for Marquette County.

${ }^{12}$ In an evocative description of cedar and its habitat, W.D. Whitney, botanist for the Foster and Whitney report of 1851, provides not only ecological insight but a description of the terrain of the area and the hardship that initial visitors to the area experienced. The description adds breadth to the understanding of what the pre-major settlement landscape of the Marquette Range was like. The white cedar is "perhaps the most abundant and widely and universally diffused of all the tree of the district. It grows in every situation; on the rough summits of the trap ridges, along the hillsides, on the plains, by the shores, but most extensively in the extensive 'cedar swamps' which cover so considerable a portion of the face of the country, filling the low grounds everywhere. Wherever there is a tract of plain land of so little inclination as not to be readily and thoroughly drained, 
there is a cedar-swamp. Nothing is more characteristic of the country, and nothing more troublesome and vexatious to those who journey about it, for the disagreeableness and difficulty of making one's way through such a swamp are extreme. The tangled, crowded mass of cedars, interlacing from the very bottom with their dead, stiff, incorruptible lower limbs, rises up out of a bed of mud and water, varying according to the situation and the season, between ankle deep and waste-deep, filled with fallen logs and rugged roots, that furnish a deceitful semblance of secure foot. The cedar of the swamps is a low, scraggy, ugly tree." In: Foster, J.W., Whitney, J.D., 1851. Report on the Geology of the Lake Superior Land District, Part II, The Iron Region, Together with the General Geology. Senate Executive Document Number 4. A. Boyd Hamilton, Washington. p.375

${ }^{13}$ Veatch, Michigan Quarterly, 1928, p. 124

${ }^{14}$ Stearns, Lake States Forests, 1997, p.3

15 Ibid.,p.3

${ }^{16}$ Jopling, James E. Ishpeming and It's Early Mines. Manuscript written October 1, 1931, unpublished in the J.M. Longyear Research Library, p.2

${ }^{17}$ Stearns, Lake States Forests, 1997, p.4

${ }^{18}$ Whitney, Gordon G. 1994. From Coastal Wilderness To Fruited Plain: A History of Environmental Change in Temperate North America 1500 to Present. Cambridge University Press, New York. p.108 and Anderton, John B. 1998. The Red River Prior to Major American Settlement: A Cultural Landscape Created by Native American Landscape Burning. North Dakota Quarterly, V.65, No.4, p. 24

${ }^{19}$ Stearns, Lake States Forests, 1997, p.5

${ }^{20}$ Fernow, Bernhard E. Quoted In: Whitney, From Coastal Wilderness, 1994, p.172

${ }^{21}$ This very important shift of land ownership, related fundamentally to the environmental history of the land, is discussed in more detail in Chapter III.

${ }^{22}$ Dunbar, Willis F. 1965. Michigan: A History of the Wolverine State Grand Rapids, MI. p. 183

${ }^{23}$ Ibid., 184.

${ }^{24}$ Ibid., 184.

${ }^{25}$ Figure 5, as well as Figures 6, 7, and 8 have been constructed with arc-view using the information concerning historical vegetation from the Great Lakes Ecological Assessment web site at http://econ.usfs.msu.edu/gla/glahome.htm integrated with digital line polygon and line hydrological graphics data.

${ }^{26}$ Veatch, J.O., Professor Emeritus, Soil Science Department, Michigan State University. From Comments on a map of the presettlement forest of Michigan which will within the next few months be available on the Great Lakes Ecological Assessment web site referred to in the previous footnote. This map will provide an less detailed alternative to the maps used in this thesis. In the early $20^{\text {th }}$ century Veatch, who was a soil scientist, traveled the state reconstructing the presettlement forests by correlating forest types and soil types. He supplemented and complemented his soils work with historical data including General Land Office Survey notes, observations of early explorers, botanical publications including lists of species present, phytogeographic maps, county histories, and verbal information from individuals.

${ }^{27}$ Whitney, From Coastal Wilderness, 1997, p.178 
${ }^{28}$ Cronon, William. 1983. Changes in the Land: Indians, Colonists, and the Ecology of New England. Hill and Wang, New York. p.110

${ }^{29}$ Whitney, From Coastal Wilderness, 1997, p.178

${ }^{30}$ Stearns, Lake States Forests, 1997, p.6

${ }^{31}$ Jopling, James E., Personal communication in Whitaker, J. Russell. 1931. Negaunee, Michigan; An Urban Center Dominated by Iron Mining. The Bulletin of the Geographical Society of Philadelphia, V.XXIX, August, 1931 p.34

${ }^{32}$ Foster, J.W., Whitney, J.D., 1851. Report on the Geology of the Lake Superior Land District, Part II, The Iron Region, Together with the General Geology. Senate Executive Document Number 4. A. Boyd Hamilton, Washington. P. 374

${ }^{33}$ Klavitter, Terry. 1991. Chapter 7: Logging in Marquette County. In: Mulligan, William H., editor and contributor. Historical Resources of the Iron Range of Marquette County, Michigan, 1844-1941. The Economic Development Corporation of the County of Marquette. p.2,3 (though it is important to note that this chapter did not have page numbers...I simply counted.)

${ }^{34}$ Ibid., p. 2

${ }^{35}$ Ibid., p. 3

${ }^{36}$ Ibid., p. 5

${ }^{37}$ Tremethick, Martin L. 1991. Chapter 6: Sawmills in Marquette County. In: Mulligan, William H., editor and contributor. Historical Resources of the Iron Range of Marquette County, Michigan, 1844-1941. The Economic Development Corporation of the County of Marquette. p.1

${ }^{38}$ Ibid., p. 6

${ }^{39}$ Ibid., p. 6

${ }^{40}$ This tram railroad is discussed in greater detail on page 17.

${ }^{41}$ Tremethick, Sawmills, 1991, p. 8

${ }^{42}$ The transfer of government owned land to the St. Mary's Canal Mineral Land Company took place upon the completion of the Sault Locks in 1855 as compensation for the work. A total of 33,000 acres in Marquette County was transferred, though J.W. Foster refers to it as more than 37,000 acres, and Swineford refers to it as 39,000 acres. This was an important step in the transfer of land from the government to private industry. More is written concerning this topic in Chapter III. The land was later sold to the Iron Cliffs company, which merged with the Cleveland Mining Company to form Cleveland Cliffs Iron in 1892.

${ }^{43}$ St Mary's Canal Mineral Land Company. Reports upon the Value of the Company's Lands Located in the Iron Region of Lake Superior, County of Marquette, State of Michigan. 1864. Wright and Potter, Boston. p.12

${ }^{44}$ Whitaker, Negaunee, Michigan, 1931, p.34

${ }^{45}$ Tremethick, Sawmills, 1991, p. 8

${ }^{46}$ Fuller, George N., Editor. 1928. Geological Reports of Douglass Houghton: First State Geologist of Michigan, 1837-1845 The Michigan Historical Commission, Lansing. p.562 ${ }^{47}$ Stearns, Lake States Forests, 1997, p.7

${ }^{48}$ Ibid., p. 9 
${ }^{49}$ Swineford, A.P. 1869, The Lake Superior Iron District. History of its Mines and Furnaces Published in Marquette, p.29

${ }^{50}$ Benison, Saul. 1953. Railroads, Land and Iron; A Phase in the Career of Lewis Henry Morgan Ph.D. Dissertation, Columbia University p.41

${ }^{51}$ Benison, Railroads, Land and Iron, 1953, p.41

${ }^{52}$ Ibid., p.42

${ }^{53}$ Ibid., p.43

${ }^{54}$ Mather, William Gwinn. 1903. Paper presented at the $9^{\text {th }}$ Annual Meeting of the Lake Superior Mining Institute August, 1903. Mather goes on to list the percentage of charcoal iron to total production in the U.S. from 1810 to 1902 . $1810=100 \%$, $1830=100 \%, 1840=91 \%, 1850=59 \%, 1860=30.3 \%, 1870=19.5 \%, 1880=12.5 \%$, $1890=6.2 \%, 1900=2.5 \%$, and $1902=2.1 \%$.

${ }^{55}$ Whitney, From Coastal Wilderness, 1997, p.219. Whitney leans toward transportation and the quality of the iron as reasons for the persistence of the charcoal iron production industry.

${ }^{56}$ Ibid., 42.

${ }^{57}$ Hunter The Heavy Industries Before 1860 in Williamson, Harold (ed.) Growth of American Economy, 172-175 in Saul Benison, 1953, p.41.

${ }^{58}$ Whitney, From Coastal Wilderness, 1997, p.222

${ }^{59}$ Ibid., p.219

${ }^{60}$ Ibid., p. 222

${ }^{61}$ Ibid., p.219

${ }^{62}$ Foster, J.W. 1865. Geology and Metallurgy of the Iron Ore of Lake Superior: Being a Report Addressed to the Board of Directors of the Iron Cliffs Company. Bryant and co. Printers, New York p. 67

${ }^{63}$ Ibid., p.67

${ }^{64}$ Brooks, T.B. 1873. Plate VIII. Furnaces Consuming L.S. Ores, Production of Pig Iron, Metallurgical and Chemical Character of Ores in Brooks, T.B. 1873 Iron Bearing Rocks of the Upper Peninsula of Michigan. Julius Bien, New York.

${ }^{65}$ Foster, Geology and Metallurgy, 1865, p. 67

${ }^{66}$ Fuller, Geological Reports, 1928, p.562

${ }^{67}$ St Mary's Canal Mineral Land Company, Reports, 1864, p.12

${ }^{68}$ Foster, J.W., Whitney, J.D., 1851. Report on the Geology of the Lake Superior Land District, Part II, The Iron Region, Together with the General Geology. Senate Executive Document Number 4. A. Boyd Hamilton, Washington. p. 363

${ }^{69}$ Foster, Geology and Metallurgy, 1865, p.66

${ }^{70}$ Buyom, Burton. 1991, Chapter 1, Iron Mining In: Mulligan, William H., editor and contributor. Historical Resources of the Iron Range of Marquette County, Michigan, 1844-1941. The Economic Development Corporation of the County of Marquette. p.C-15 ${ }^{71}$ Ibid., p.C-15

${ }^{72}$ Ibid., p.C-15

${ }^{73}$ Ibid., p.C-16

${ }^{74}$ Ibid., p.C-16 
75 The difference between a cold and hot blast furnace involves whether the air that is forced into the forge through the tuyeres is heated or not heated. The heated air of the hot blast makes the smelting process more efficient.

${ }^{76}$ Lake Superior Journal, June 25, 1851 published at the time in Sault Ste. Marie.

${ }^{77}$ Swineford, Lake Superior Iron District, 1869, p.7

${ }^{78}$ Buyom, Iron Mining, 1991, p.C-20 and Morgan, Lewis Henry. 1855. Opinion Cited, entry August 3, 1855. In: Benison, Railroads, Land and Iron, 1953, p.96

${ }^{79}$ Buyom, Iron Mining, 1991, p.C-20

${ }^{80}$ Ibid., p. C-20

${ }^{81}$ Swineford, Lake Superior Iron District, 1869, p.7

82 Buyom, Iron Mining, 1991, p.C-21

${ }^{83}$ Ibid., p.C-21

${ }^{84}$ Lewis Henry Morgan was a noted anthropologist and biologist. An attorney from Rochester, New York, Morgan first arrived on the Marquette Range in the employment of Heman Ely, of whom more is written in Chapter IV. Morgan became quite involved on the Range and had the Morgan Furnace built. He visited the Range every summer during the 1850's. Morgan made serious contributions to early biology and anthropology. The American Beaver and Ancient Society are important works in each field.

${ }^{85}$ Morgan, 1855, in Benison, Railroads, Land and Iron, 1953, p.96

${ }^{86}$ Brooks, T.B. 1873. Plate VIII. Furnaces Consuming, The actual numbers are as follows: The Pioneer had 105 company employees and 200 contractors. The Collins employed 18 company employees. Bancroft employed 110 contractors. The Morgan employed 150 company employees and 75 contractors and the Deer Lake Furnace had 75 in both categories.

${ }^{87}$ Swineford, Lake Superior Iron District, 1869, p.29

${ }^{88}$ Ibid., p. 29

${ }^{89}$ Ibid., p. 29

90 Ibid., p.29

${ }^{91}$ Rominger, C. 1881. Geologic Survey of Michigan. Upper Peninsula, 1878-1880

Volume IV. Published by the Authority of the Legislature of Michigan, Under the

Direction of the Board of Geologic Survey. Julies Bien, New York. p.3

${ }^{92}$ Whitney, From Coastal Wilderness, 1997, p.221

${ }^{93}$ William Gwinn Mather was president of CCI, and his father preceded him.

${ }^{94}$ Mather, Paper presented, 1903. It is important to note that although the furnaces in 1902 used an average of 2.5 cords of wood per ton of iron made, most furnaces prior to this were not as efficient.

95 Swineford, Lake Superior Iron District, 1869, p.30

96 Ibid., p.31

97 Brooks, T.B. 1873. Plate VIII. Furnaces Consuming.

${ }^{98}$ Whitney, From Coastal Wilderness, 1997, p.224

${ }^{99}$ Ibid., p. 224

${ }^{100}$ Swineford, Lake Superior Iron District, 1869, p.32 Swineford states that the Morgan Furnace under the direction of "one of the most practical and efficient iron masters" on 
the Range: C. Donkersley made in its first ten months a clear net profit of 220 percent. This allowed the company to pay back all of the original outlay for the land and machinery. He goes on to say that the Morgan had made the best run of any furnace in the district with the Greenwood, under the same management finishing second.

${ }^{101}$ Ibid., p.32

${ }^{102}$ Buyom, Iron Mining, 1991, p.C-27

103 Ibid., p.C-23

${ }^{104}$ Swineford, Lake Superior Iron District, 1869, p.29

105 Trowbridge, C.A. to Trowbridge, L.S., January 6, 1868. Luther Trowbridge, Manuscript In: Benison, 1953, p.246

${ }^{106}$ Whitaker, Negaunee, Michigan, 1931, p.33

${ }^{107}$ Parks, Roland 1928 Timbering Practice in the Michigan Iron Mines L.S.M.I. Proceedings, 26 p.168-9 in Whitaker, 1931, p.48

108 Zon, Rapheal 1925. Forestry and Mining in the Lake Superior Region L.S.M.I.

Proceedings, 24 p.271 in Whitaker, Negaunee, Michigan, 1931, p.47

${ }^{109}$ Ibid., p.34

${ }^{110}$ Hatcher, Harlan 1950. A Century of Men and Iron Bobbs-Merrill, Indianpolis p.144

${ }^{111}$ Whitaker, Negaunee, Michigan, 1931, p.48

112 Ibid., p.48

${ }^{113}$ Ibid., p.49

${ }^{114}$ Mather, paper presented, 1903

115 Ibid.

116 Stearns, Lake States Forests, 1997, p.10

${ }^{117}$ Whitney, From Coastal Wilderness, 1997, p.193

118 Ibid., p.194

${ }^{119}$ Stearns, Lake States Forests, 1997, p.10

${ }^{120}$ Whitney, From Coastal Wilderness, 1997, p. 198

${ }^{121}$ Ibid., p.199

${ }^{122}$ Stearns, Lake States Forests, 1997, p.10

${ }^{123}$ This map is constructed using NOAA Advanced Very High Resolution Radiometer satellite imagery. The map represents information from the 1990 growing season (early March to mid-November). Forest classification was performed by the Forest Service. Digital line and polygon hydrology graphics are also shown.

${ }^{124}$ Cronon, Changes, 1983 , p. 126 


\section{CHAPTER III. \\ PROPERTY AND LAND USE ON THE MARQUETTE RANGE}

Introduction/The Anishnabeg Existence On the Marquette Range/

The Anishnabeg View of the Land/ The American View of the Land/Early Federal Land Policy/Federal Land Grants and Transportation Improvements on the Marquette Range/

The Federal Dissolution of Aboriginal Title/Indian Treaties/The Treaty of La Pointe

The Anishnabeg View of the Treaty of La Pointe/Conclusion

\section{Introduction}

The ecological and geological transformation of the Marquette Range, expressing itself in deforestation and the introduction of non-native species, as well as the large scale extraction of iron ore from the area, was almost exclusively a result of the settlement of the Range by European-Americans beginning in the mid- $19^{\text {th }}$ century. The arrival of American culture, of a society defined in large part by its capitalist economic system, was the key causal factor in the extraordinary change that occurred to the natural features of the Range. The European-American settlers brought with them, from the myriad places of their origin, a political organization, a system of production, and a relationship with the natural world that created an entirely new landscape, defined by resource extraction. Their existence was in many ways radically different from the aboriginal culture they displaced. That aboriginal culture, the Anishnabeg Tribe, lived in small bands and hunted and fished in the area, for many centuries before the arrival of the EuropeanAmerican settlers to the area.

As the American Frontier moved westward, the expansion of the nation greatly accelerated by the mineral rush that occurred in the Upper Peninsula of Michigan, the land that belonged to the Anishnabeg became populated with large numbers of American settlers. This shift from Anishnabeg to European-American dominance on the Range witnessed the replacement of a mostly subsistence based hunter-gatherer society with a system where certain select commodities acquired from fixed property boundaries were 
linked with commercial markets. This economic shift, which occurred over an extended period of time and through economic, social and political interactions between the two cultures, had far reaching effects on the natural system.

The land of the Marquette Range was ceded to the U.S. Government from Great Britain following the Revolutionary War ${ }^{1}$ and, eventually, aboriginal title to the land was extinguished through the Treaty of La Pointe signed with various bands of the Anishnabeg, in $1842 .^{2}$ After the land was purchased and then surveyed by the Federal Government, it was made available for sale to individuals with ownership of the land acquired through legal purchase from the government, involving ownership of everything within the tract of land purchased. No longer were the resources of the land used only for subsistence; now with the attachment of property to a market, land was used to accumulate capital. This was an early and very important step in the environmental history of the Range.

As the Anishnabeg were displaced by American capitalist culture, an environmental dialectic developed, where human systems affected nature in radical and far reaching ways, just as the modified natural systems redefined, and added context to, the humans. Historical changes in the modes of production from the Anishnabeg to American cultures are recognizable in the processes and long term changes of the geological and ecological systems of the Marquette Range. Conversely, the switch from the one mode of production to the other, and the resultant reorganization of the natural systems present on the Range, can be followed through the economies, class systems, political organizations and cultural rituals on the Range, the context for which the environment provided.

\section{The Anishnabeg Existence On the Marquette Range}

Prior to the major settlement of the area by European-Americans, scattered Indians of the Keweenaw Bay (We-qua-dong) Lake Superior Anishnabeg Tribe lived on the shores of Iron Bay and the wooded hills of the Marquette Range. ${ }^{3}$ The Anishnabeg were mostly fishers and hunters, however, they drew from many sources within the 
natural environment for their survival. The division of labor within the Anishnabeg society was not well developed, so that because individuals interacted continually with many parts of their surrounding environment, acquiring first hand knowledge of its condition, their society had a broad based knowledge of the many ways it impacted, and was impacted by nature. An analysis of the way in which the Anishnabeg lived on the Marquette Range, for hundreds of years before American settlers arrived, is an analysis in the stark contrast of how these societies existed on a day to day basis, throughout the entire lives of the individual members of the societies. The Anishnabeg produced goods from the nature that surrounded them in order to accomplish security rather than maximum yield, and they concentrated on diversity rather than the abundance of any single commodity. ${ }^{4}$ They did this because each of the commodities they produced represented a safety net for themselves and their culture, and to them this was in a sense their definition of success. The Anishnabeg existed on what was abundant at different times of the year, and by following the seasonal cycles, and diversifying their diet, achieved security. They did not concentrate on manipulating nature to produce the maximum yield of a certain commodity, but instead concentrated on the production of the many commodities provided within the natural spectrum. If the Anishnabeg had concentrated on trying to maximize a part of the productive cycle at the cost of others, trying to, for instance maximize their catch of fish at the cost of small scale agriculture, this would have undermined their diversity and decreased their security. ${ }^{5}$

To increase their collection of safety nets, the Anishnabeg augmented the wild fish and game they caught by gathering a large variety of plants from the forests for food, building material, and medicines, and by planting small tracts for the cultivation of corn, beans, and squash during the short northern growing season. During the extended summer days, the Indians formed small villages, typically occupied by 50 to 75 people, on the southern shores of Lake Superior. ${ }^{6}$ Figure $12^{7}$ shows the locations and distribution of the Anishnabeg summer settlements during the $19^{\text {th }}$ century. From these bases of social activity, men of the bands would make extended periodic hunting excursions, while women would gather from what was provided by nature and overlook small 


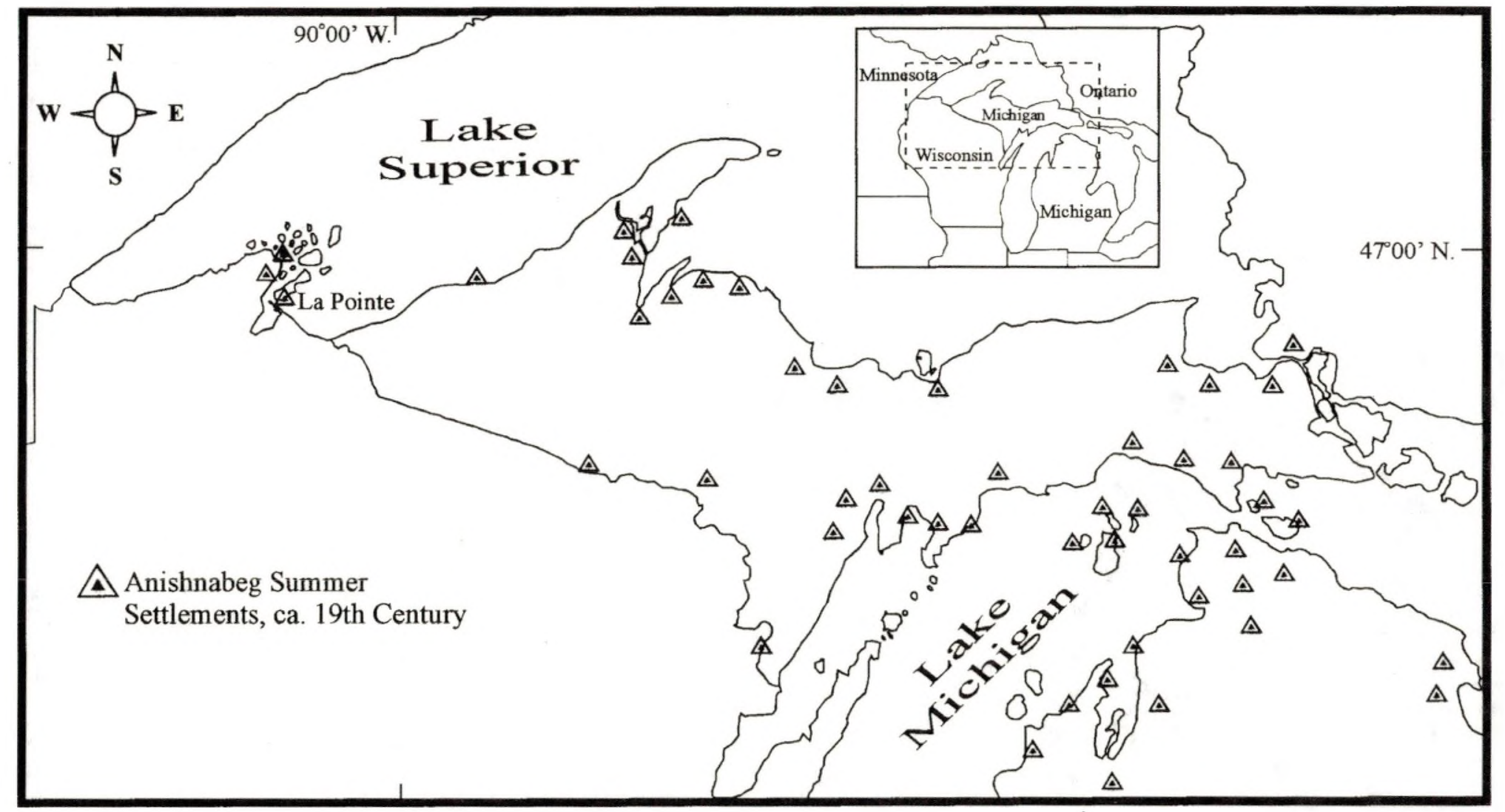

Figure 12. Anishnabeg Summer Settlements, ca. 19th Century 
gardens planted in the valleys close to the lakes. Both the men and women would augment these activities by fishing with hook and line, and gill nets for whitefish and lake trout; spears and harpoons were also employed for large species such as sturgeon and suckers. In late fall some of the summer villages coalesced to a few particularly productive fishing spots. During these times men braved the sometimes stormy waters of the lake to net spawning species of fish on offshore reefs, while women mended lines, and cleaned and preserved (usually by smoking, sometimes by freezing) the catch. Upon the completion of the fish harvest the communities disintegrated and independent, autonomous families took up residence in the interior of the peninsula at hunting territories recognized by custom and defined by tradition. On this land, surviving the dark, and sometimes harsh northern winters, the Anishnabeg hunted moose, caribou, bear, beaver and some deer; they also fished through the ice and ate stores of dried berries and smoked whitefish. In the spring the Indians returned to the south shore of Lake Superior; as the ice went out, they speared suckers and sturgeon entering the streams to spawn. ${ }^{8}$ The societal cooperation of the Anishnabeg, was centered on the nuclear and extended family with kin relations overriding economic definitions of communal interaction between individuals. In the spring, summer, and winter seasons there was no need that could not be provided by small groups of men and women. Fall was the only exception to this autonomy with the necessary formation of large villages associated with the need to process large amounts of fish. ${ }^{9}$

\section{The Anishnabeg View of the Land}

The way in which the Anishnabeg existed on a day to day basis defined the way in which they viewed property and land policy within their culture. In this aspect the Indians also differed greatly from the large numbers of Americans that would follow them, and the difference in the two philosophies of land use and property ownership became markedly evident in the reaction of the natural world to each. ${ }^{10}$ The property rights of the native inhabitants of the Marquette Range were defined by and shifted with ecological use. Property rights were not defined by arbitrary boundaries, but were rather 
defined by the resources of the land, varying with need, and with the seasons. The boundaries of the rights to use things on the land were gradational, transient, and defined in large part by the Anishnabeg perception of the natural features of the land, hence, the land was not owned but rather the products of the land were used for the survival of individual families. The provisions of nature led to a system of usufruct property rights, where rights to land did not include prevention of trespassing, and there was no conception of acquiring rent. ${ }^{11}$ Kinship amongst the Anishnabeg accomplished the allocation of the bundle of usufruct rights to individual families in a society marked in its absence of ubiquitous legal institutions. The familial political structures and principles of organization delineated land use that was defined by the cultural perception of natural factors. In many ways this kinship relationship, core to all social relations among the

Great Lakes Anishnabeg, ${ }^{12}$ was a reason why American land policy failed to fully understand Indian views of property in the area, and why the majority of land interactions between settlers and Indians were frictional.

\section{The American View of the Land}

The land policy of the American government, incapable of recognizing the general reciprocity of social kinship relations which defined Indian economic transactions, forced land to be viewed within the capital system as a tradable commodity, the land itself sold and owned regardless of the intended use. The difference between the American and Anishnabeg land policies hardly could have been more profound. The boundaries of the land sold could not be transient, but rather were fixed and definite and the owners of abstract parcels owned all of the usufruct rights within the parcel. ${ }^{13}$ This difference in land policies was tied to the difference in the economic systems of the two peoples, with the Anishnabeg system based on a more conservative and secure use of an abundance of natural commodities, and the American system based on an attempt to maximize the production of select natural commodities. This transition from a mostly subsistence culture to a market economy had profound affects on the ecology and history of the Marquette Range. The Indians prized timber, fish, game and plants for their 
immediate utility and in some cases for their spiritual value; however, EuropeanAmericans prized these items, with the addition of iron, for the prices they could attain when exchanged within a market. The commerce of the capital system, completely alien to the Indian political system of kinship, defined natural products of the land as merchantable commodities, with market demand and not survival becoming the key causal agent in ecological changes. ${ }^{14}$

Conditioned by the American Capitalist economic base, collective social themes began to emerge within American society castigating Indians for their failure to throw aside their safety nets in favor of a market based maximization of certain economic commodities. Indians were berated for being lazy and slothful and for their failure to improve the land. ${ }^{15}$ Supported by these collective social, ideological themes, based on an oversimplified and limited viewpoint, the U.S. Federal government usurped very nearly the entirety of land under Indian title. The settlement and related transformation of this usurped land was delimited by a property system defining land as capital with fixed, definite boundaries in conjunction with the ability to use the land for any purpose allowing for assurance to individuals that their improvements belonged to themselves and their heirs. These improvements to the land translated into abstract money value present in tax assessments, inventories of estate, and in the land market. The ideology was part of an ever expanding economy, constantly gaining in efficiency, and consistently more ecologically transformative. ${ }^{16}$ Profit of individuals and of the entire capital system came at the cost of trees removed and land scarred. Wealth was created at the cost of the land.

\section{Early Federal Land Policy}

In order to begin to understand how American land policy was formed, we must look at the policy within the early stages of the nation. Between the end of the Revolutionary War and the mid-nineteenth century, over a billion acres of land was ceded to the U.S. Federal Government through treaties with France, Spain, Great Britain, and Mexico. ${ }^{17}$ The decision of what to do with this acquisition was a controversial and hotly contested political subject in the formative period of the nation. Faced with a large debt 
following the conflicts with Great Britain early in its history, the Federal Government decided that the best plan was to convert the surplus of land available in the west into money. The incredible opportunity for revenue generation that this land provided led to a very liberal land distribution policy, with this policy stimulating the settlement of the American frontier, and fueling a young and indigent economy. The increase of the settlement of the land was not only very economical for the fledgling nation, but also provided security on the western frontier. Only one hindrance threatened this policy: the land they were planning to sell in order to lessen their economic problems, and settle to increase the national security, was already occupied. The occupants of the land were the American Indians and, under American Law, the land that was acquired through treaties with other nations, was legally owned by these Indians who had originally occupied it. Indians, treated as a sovereign nation by the Federal Government, held aboriginal title to the land, and treaties with individual Indian nations were necessary before the surveying and the sale of the land could occur. ${ }^{18}$

At the beginning of the nineteenth century, America was still a nation clinging to the shores of the Atlantic Ocean. Early in the nation's history, certain seaboard states held claims to land west of the Appalachian Mountains extending to the Mississippi, however, during the Confederation period, the seaboard states gave up their claim to these lands and turned them over to the Federal Congress for control. From 1803, extending into the middle of the $19^{\text {th }}$ century, the Federal Government added the Louisiana Purchase and other land claims to the land that it controlled east of the Mississippi, so that by 1853 the size of U.S. controlled land equaled approximately 1.4 billion acres. ${ }^{19}$

Interest in the western lands, and at what price these lands would be sold varied considerably in different regions of the United States. The seaboard states that had given up their claims to the Federal Government, were concerned that a policy including low prices for the land would draw migrants westward. It was their opinion that a viable, productive west would create a surplus of food and raw materials that would negatively affect the status of eastern land values. This, however, was not an unanimous opinion in 
the states on the Atlantic, with many believing that the generation of capital from the sale of the lands would produce a surplus of cash that could be distributed from the Federal Government to the states that had ceded the western claims. New England attitudes toward the western lands varied greatly between agricultural and industrial concerns and also along class lines. Successful New England farmers favored a conservative land policy, wary that cheap and fertile western lands would undermine their success, however, other New England farmers saw in the lands a possibility for migration and a more prosperous future. Most New England industrialists, very much in favor of a large, highly competitive work force allowing for low wages, opposed land liberalization and the out migration that would be the result of cheap land prices. On the other hand there were a few industrialists that saw possibility in a growing west as a market for their products, and still others that saw an open west as helpful in the fight against slavery. The factory workers, similarly to the unprosperous farmers saw in the western lands possibility and a guarantee against economic exploitation, and, therefore, favored cheap land prices. ${ }^{20}$

Juxtaposed to these thoroughly divided interests, the trans-Appalachian west, which grew in size greatly after the War of 1812 , was uniformly supportive of a policy of land liberalization through cheap land prices. It was their collective belief that economic factors alone should not determine western policy and they pointed to democratic, Jeffersonian ideals concerning property owning farmers on small plots of land as being most beneficial to the protection and success of an egalitarian America. The doctrine supported by the west, stating that public lands could be used to shape economic and social institutions in American democracy, slowly gained momentum in the $19^{\text {th }}$ century with its ultimate triumph being the Homestead Act of 1862. With an increase in the control of Indian hostility in the west, providing safety to settlers, migration began to sharply increase. ${ }^{21}$

Prior to 1796, the policy of the Federal Government concerning land sale mandated that interested consumers purchase a minimum of 640 acres of government land, at two dollars an acre. In the year 1800, William Henry Harrison, at the time 
delegate to the Northwest Territory, successfully recommended that the minimum area of purchase be reduced to 320 acres, with a system of installment payments also set up to help settlers meet the restrictively high prices. The Land Act of 1820 abolished this system of credit because many settlers purchased land in excess of what they could pay for with the new act mandating cash payments for government land. To make up for this change in policy the act stipulated that the minimum purchasable tract be reduced to 80 acres and that auctions be held to sell land starting at a price reduced to $\$ 1.25$ per acre. ${ }^{22}$

In the 1820's and 1830's as western political power increased and their views on land policy became more influential within the country, the subject of squatters on the land began to be addressed. Squatters, settlers on public land using the resources of the land without legal ownership rights to it, were viewed by the trans-Appalachian western states as a benefit to the nation, because although it was still officially illegal, they cultivated and settled wild lands. Under existing laws, the rights of squatter's were limited to participating in the auction for the land they had cleared after the land was surveyed and this could easily result in the squatter being out bid for the land, and losing years of work. In 1830, Congress gave rights to squatters by enacting a measure constructed from western petitions that allowed pre-emption, or the ability of squatters to buy their land for $\$ 1.25$ an acre before the auction was held. By 1841 , a permanent preemption law providing rights not only for the established squatter but also allowing for prospective squatter rights was established. The Pre-Emption Act of 1841 provided rights, not limited in time, for any future settler to settle anywhere on surveyed lands in anticipation of buying those lands; gradually, even unsurveyed lands became open to legal, prospective squatting. The act forced the auction system into irrelevance, with all land able to be purchased at $\$ 1.25$ an acre. The western land liberalization legislation was heavily intertwined with other economic issues of the day and as a concession to the rest of the nation, the act provided that the majority of the funds from land sales be distributed amongst the states and territories based on respective Federal representative population. Another economic concession of the act provided a significant tariff to the southern states. ${ }^{23}$ 
The Graduation Act of 1854 was a further concession to western demands claiming that not all land offered was of equal value. An assessment of the quality by the government of all public lands offered for sale was not possible, so a sliding scale of price for land was established that linked the price of the land to how long the land was offered on the market. This sliding scale of minimum purchase prices for unsold land helped to alleviate the economic burden of land unsold and, as a result, non-taxable for the Federal Government, by stimulating the sale of all but the most undesirable plots. The graduated scale lowered prices to a minimum of 12.5 cents an acre for land that had been on the market for over 30 years. ${ }^{24}$

\section{Federal Land Grants and Transportation Improvements on the Marquette Range}

On the $20^{\text {th }}$ of September, 1850 Congress granted approximately two million acres in public lands to a private company to aid in the construction of the Illinois Central Railroad. ${ }^{25}$ The act set an important precedent for similar measures throughout the country and by 1852 a law was passed granting right of way through public lands for all sanctioned railroads under construction. June $3^{\text {rd }}, 1856$ the Federal Land Grant Act was passed, further encouraging the development of transportation throughout our nation by establishing a railway grant system which provided land to railroads that laid track through an area. ${ }^{26}$ The grant system provided railroad companies with alternate sections of land between five and ten miles on either side of the tracks laid. This land, a necessity for the construction of the lines, also could be logged and mined for the profit of the railroad, and could be sold to those interested in the property adjacent to the line. The Federal Land Grant Act gave grants of land to eight lines in Michigan, three of which were in the Upper Peninsula. The three perspective lines in the Upper Peninsula all had as their terminus the town of Marquette.

Grants of land from the states also provided railroad companies with land for the construction of the road and for the generation of capital. Beginning in the 1850's the state of Michigan, no exception to this trend, bolstered railroad construction by making available public land grants to railroad companies meeting certain eligibilities. The 
grants provided for land on either side of the proposed road to be given to railroad companies, with any natural resources on the land falling into the hands of the railroad builders. ${ }^{27}$

In addition to the grants of land by the Federal Government and the states that would eventually stimulate the development of several very important railroads on the Marquette Range, the government was also closely linked through land grants to the building of the Soo Locks. These locks connected Lake Superior with the lower great lakes and allowed ships to bypass the 17 foot high, mile long rapids of the St. Mary's River at Sault Ste. Marie. The rapids had constricted transportation in the area since the beginning of boat travel by forcing boats and goods to be portaged over the distance. In 1852, Congress granted 750,000 acres of land to be distributed from the state of Michigan to a private interest in order to pay for the construction of a canal at Sault Ste. Marie. ${ }^{28}$ The contract eventually went to the St. Mary's Falls Ship Canal Company with the land grant as the sole compensation for the work. Early in 1853 construction began on the canal. The process was a arduous endeavor: of the 400 workers who began the project, approximately 200 died of cholera. The canal finally opened in June of 1856, allowing steamers carrying goods to sail between Lakes Superior and Huron and opening up the Lake Superior area to development. ${ }^{29}$

In addition to the improvement of transportation in the area, the canal land grant had a profound affect on the distribution of property ownership on the Marquette Range. Since the land of the Range was highly valued for its timber and mineral resources, the St. Mary's Canal Mineral Land Company used a great deal of the land grant to claim parcels in the area. Of the 262,283 acres of iron, copper and timber land in the Upper Peninsula selected by the general agent and superintendent of construction for the St. Mary's company: Charles T. Harvey, 39,000 acres were in Marquette County. ${ }^{30}$ The company eventually sold the property on the Range to the Iron Cliffs Company for 500,000 dollars cash, which used the land's timber to fuel the many furnaces of the area and extracted the mineral resources of the land. ${ }^{31}$ Figure $13^{32}$, a map from the 1865 report to the board of directors of the Iron Cliffs Company by J.W. Foster, shows the 


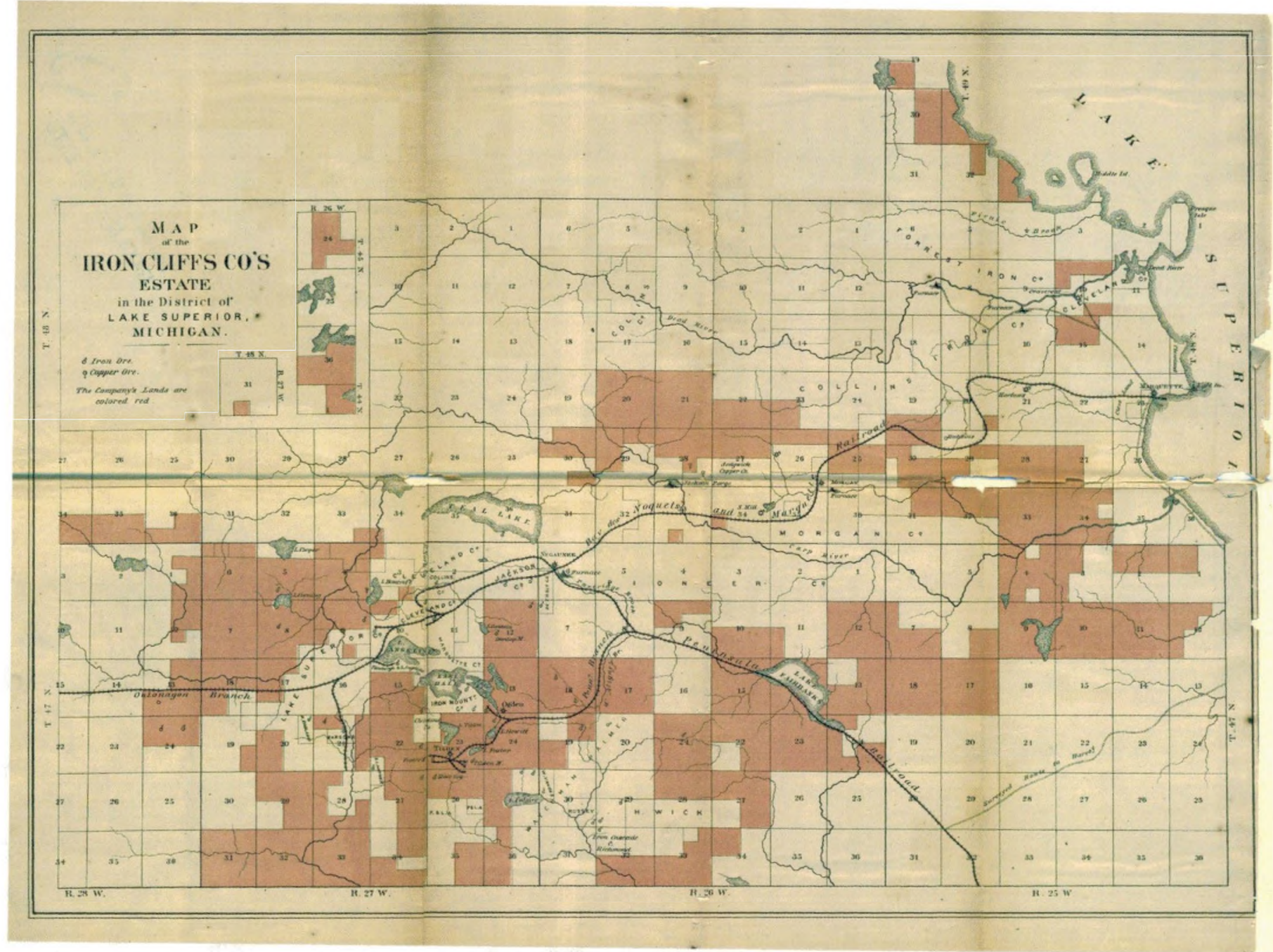

Figure 13. Distribution of Iron Cliffs Company Land Aquired From the St. Mary's Mineral Land Company Government Land Grant on the Marquette Range in 1865 
distribution of this rather extensive land grant on the Marquette Range, and is an example of the large land holdings of the mining and timber companies on the Range.

\section{The Federal Dissolution of Aboriginal Title}

Before any of the land of the Marquette Range could be sold to individual interests, and before any of the large transportation projects of the area could be realized, in part, through grants of Federal land, the property had to first be acquired by the government from the Anishnabeg. This land of the Upper Peninsula of Michigan, ceded

to the U.S. from Great Britain following the Revolutionary War, was recognized as being owned by the initial inhabitants. Legitimate aboriginal title to the land holdings and resources of the land, a result of original occupancy, had as its antecedent established Western law and judicial philosophy. This law stated that aboriginal title could be extinguished through conquest in rightful wars or by purchase. ${ }^{33}$ The Crown Proclamation of 1763 , later transferred to the U.S. through the Treaty of Paris at the end of the Revolutionary War, established that aboriginal title could only be transferred to the government; the government became the sole intermediary in the transfer of Indian land to American settlers. An exclusive relationship between the Indians and the Federal Government in the transfer of land was forged aimed at reducing the excessive confusion which resulted in the interactions between Indians and the settlers that were interested in buying their lands. This allowed the government to employ a more focused policy of land usurpation. ${ }^{34}$ In theory, the Federal Government treated this exclusive relationship in land exchange, aimed at reducing confusion, as a political negotiation between itself and a sovereign nation of American Indians, however, in actuality the transaction was mostly economic and contained solely within American jurisdiction. ${ }^{35}$

Two national policies emerged to promote American dominion of land through the usurpation of aboriginal title from the Indians. Both policies were based in a perceived incompatibility of the cultures, social institutions, and economies of Indians and European-Americans and the policies set the stage for the dispossession of almost all Indians of their land. ${ }^{36}$ Dominating Indian policy in the American political spectrum in 
the first half of the $19^{\text {th }}$ century, the concept of removal led to the forcible relocation of mid-west Indians to land west of the Mississippi River. This policy, known as the Removal Policy, and officially adopted by the U.S. Government in the 1830's, is best described as a policy that attempted to place certain cultures out of sight, and out of mind. Moving the cultures westward was, in theory, justified as a way of preserving a culture that was incongruent with the ways of America. The policy ignored how these Indian tribes were acclimated to eastern and mid-west ecosystems, and how the transition to living on the Plains was for these cultures nearly impossible. It also ignored the fact that areas west were occupied by other aboriginal tribes, in many cases hostile to settlement in their territory. ${ }^{37}$ The Removal Policy, founded in racist polices related to Manifest Destiny, created profound hardships for Indian tribes forcibly transported west, and was tantamount in many cases to the obliteration of these tribes.

As information concerning the hardships and inhumane treatment of Indian tribes under the Removal Policy trickled out to the American public, the negative reaction to the lack of ethics involved in the policy created a call for change. As a reaction to the Removal Policy, the second national policy for the usurpation of the aboriginal title emerged in the form of the Civilization Policy. The country's philosophy went from an attempt at removal, to that of integration of Indians into American economic and social systems. The policy concentrated on training Indians in the use of agricultural techniques, and also forcibly teaching the Indians English, and Christian religious philosophy. This imposition of the American cultural institutions of language, law, land tenure, marriage, inheritance, and child rearing, was based in moral and righteous goodwill, but resulted, commonly, in the destruction of Indian economy, social systems, and religions. ${ }^{38}$ Working in conjunction, the two policies of the $19^{\text {th }}$ century U.S. Federal Government toward the Indian tribes within its boundaries led to the usurpation of the vast majority of land under Indian title. After surveying the land, the government immediately put it up for sale and the resources of the land, from productive soil to timber and minerals, were transferred temporarily into Federal holdings and then sold to individuals. The Indians were left on island reserves surrounded by what were, in many 
cases, hostile European-American settlers, unable to participate in their traditional means

of livelihood and subject to intense political, economic, and religious indoctrination. ${ }^{39}$

\section{Indian Treaties}

Although the displacement of the Anishnabeg through the settlement of the Marquette Range by European-Americans became very rapid following the mineral discoveries on the Range in the mid- $19^{\text {th }}$ century, the settlement process began much earlier than this and was a long and distended affair involving complex interactions between the cultures. This displacement came about, broadly speaking, through a long process of environmental change and through an increase in the interaction between the Americans and Indians. ${ }^{40}$ Slowly, over the course of many decades, the Anishnabeg, like many Indian cultures throughout North America, became increasingly more dependent upon the goods provided by the dominant economy of the European-American culture, and this dependence led, eventually, to their loss of the land. ${ }^{41}$ Through trade at the early posts of Sault Ste. Marie, L'Anse, Grand Island and La Pointe, European goods penetrated Anishnabeg society, and as the goods slowly began to displace the technology of the Indians, they ceased to be an entirely autonomous people, their political and cultural life, as well as their resources, began to be out of their control. As the market economy became more prevalent in the area, certain resources came to be over exploited, which led to the Indian subsistence economy being undercut, and the reliance of the Indians on outside aid. ${ }^{42}$

The fur trade played an important role in this process. Beginning as early as the $17^{\text {th }}$ century companies such as the American Fur Company in America and the Hudson Bay Company in British controlled territory began trading with the Anishnabeg, generally trading European textiles, alcohol, guns and metal goods to the Indians for furs, food, and land. ${ }^{43}$ The exchange was not purely driven by economic exchange and over many years, and through many exchanges, social relationships were built between the traders and Anishnabeg. With time, however, the exchange became more established as commercial and the Anishnabeg began to find that the way to receive the goods that they 
were becoming more and more reliant upon in their daily lives was through direct economic exchange. As the exchange became more commercial, the Anishnabeg view of the animals they acquired furs from became more commercial, and with increased trade came increased hunting, and associated severe declines in the animal population. ${ }^{44}$ With the decrease in the animal population, the Indians no longer had the resources to exchange for the goods they wanted and needed. Traders often advanced loans to the Anishnabeg, and sometimes used these debts to coerce greater hunting from the Indians, and later the transfer of the title to their land. This occurrence of events was so pervasive in the American dealings with Indians during the $19^{\text {th }}$ century that its implementation was practically a national policy of land acquisition. On the $27^{\text {th }}$ of February, 1803, Thomas Jefferson wrote a letter to William Henry Harrison that broadly outlined this philosophy. He wrote, "To promote this disposition to exchange lands...we shall push our trading houses and be glad to see the good and influential individuals among them run into debt, because we observe that when these debts get beyond what the individuals can pay, they become willing to lop them off by a cession of lands...In this way our settlements will gradually circumscribe and approach the Indians, and they will in time either incorporate with us as citizens of the United States or remove beyond the Mississippi."

Traders played an integral part in the U.S. Government's ability to gain title to the land of the Indians. In addition to the economically enervating effect of the loans the traders granted to the Indians, they also forged social relationships of trust and obligation with the Indians. The traders were, in many cases, the only contact that the Indians had with the American political system, and some traders married Indian women, and became part of the system of kinship so important to the Indian political structure.

The official process of the transfer of dominion from aboriginal title to U.S. ownership involved the creation of Indian Treaties. The status of Indian tribes under American law, derived from English law through the Treaty of Paris, was that of a nation within a nation so that each treaty constructed with individual Indian tribes was subject to approval by the U.S. Senate. Indian treaties, though in theory similar to treaties made between equal sovereign political nations, in actuality were unique entities that were 
entirely instigated and promoted by the U.S. Government, and created entirely within American jurisdiction. For the Indians the dice were loaded; the treaties were almost always the result of economic interests and the impetus behind them often stemmed from the desire of capitalists within the U.S. to acquire specific lands. ${ }^{46}$ The treaties were often so contrived that, in many cases, the Federal Government concocted Indian political entities for the purpose of specific treaty construction. They could not be burdened with the confusing aspects of different bands within a tribe and with trying to figure out the Indian hierarchical structure in order to pay the money to all of the rightful aboriginal title holders. The details of what tribe was being dealt with, and what land was being acquired meant little to the government; the important matter was to buy off the Indians with as little money as possible and open up the land for settlement. The men in charge of treaty making such decisions rarely followed the advice of Lewis Cass when he wrote of the process November 21, 1824:

The metalliferous region (in this case Cass was referring only to the copper of the area) is upon and about the Lake shore, and the extinction of the Indian title to such a portion of it, as may be deemed advantageous, would not diminish their subsistence... The cost of making the purchase I have described, may be kept within the sum of ten thousand dollars, and full justice be done to the Indians interested. It might, I doubt not, be made for a much less sum, were it consonant to the principles or policy of the Government to procure cessions from the Indians at the lowest possible rate. But it is due to the character of our country, and to the feelings of our citizens, that, in our negotiations with these wretched people, we should remember our own strength and wealth, and their weakness and poverty. That we should look back upon what they have lost and we have gained and never forget the great moral debt we owe them. ${ }^{47}$

\section{The Treaty of La Pointe}

What would become the state of Michigan was transferred initially into the possession of the Federal Government through a series of treaties starting with the Greenville Treaty in 1795 and ending with the La Pointe Treaty of $1842 .^{48}$ Before 1818, in the State of Michigan, only small areas of land near Detroit and Makinac were available to purchase through legal permit. Squatters were prevalent through the state, 
however, these settlers were without legal title and risked losing their land to others who might out bid them once the land was put up for sale; not until the Pre-emption law of 1841 did squatters begin to receive rights for land they settled without owning. Beginning in 1819 with the Saginaw Treaty, and continuing with the Chicago Treaty of 1821, the Treaty of Washington in 1836 and the Treaty of La Pointe in 1842, several very large tracts of the land of Michigan were ceded from numerous Indian bands to the U.S. government. ${ }^{49}$

Of the land of the Upper Peninsula, four treaties, beginning in 1820 and ending in 1842, transferred aboriginal title to the American Government. The land of the Marquette Range was transferred from the Anishnabeg to the government through the La Pointe Treaty of 1842 . Figure $14^{50}$ shows the area that was covered by the four treaties relevant to the Upper Peninsula along with the years each treaty was concluded. The articles of the Treaty of La Pointe were made and concluded at La Pointe on Madeline Island in the Apostle Islands of Lake Superior, in the territory of Wisconsin on October 4, $1842 .^{51}$ La Pointe was a summer and fall settlement area for the Anishnabeg (see Figure 12) and also a trading post for the American Fur Company. Of the post in 1841, Charles Penny wrote, "It has a most excellent harbor, is on elevated dry ground, and looks clean and wholesome. The American Fur Co. have expended a good deal of labor and money here. They have two large red buildings occupied as a store and storehouse, a good wharf and a fish house two hundred and fifty feet long, besides four or five dwelling houses clap boarded and painted white...There are about 40 lodges, and the Indian Population numbers about 300 . There are about 46 dwellings, most of which are occupied by old voyageurs, half-breeds \&c." 52 Penny went on to describe the community of La Pointe: "The American, French, and mixed population numbers near 300. But all the different races are so mingled that a classification would be impossible. From the purest white to the most swarthy complexion there are innumerable shades-'Shade softening into shade and also forming an harmonious whole.", 53

The official title of the treaty concluded at La Pointe was the Treaty with the Chippewa, 1842 (throughout the rest of the work it will be referred to as the Treaty of La 


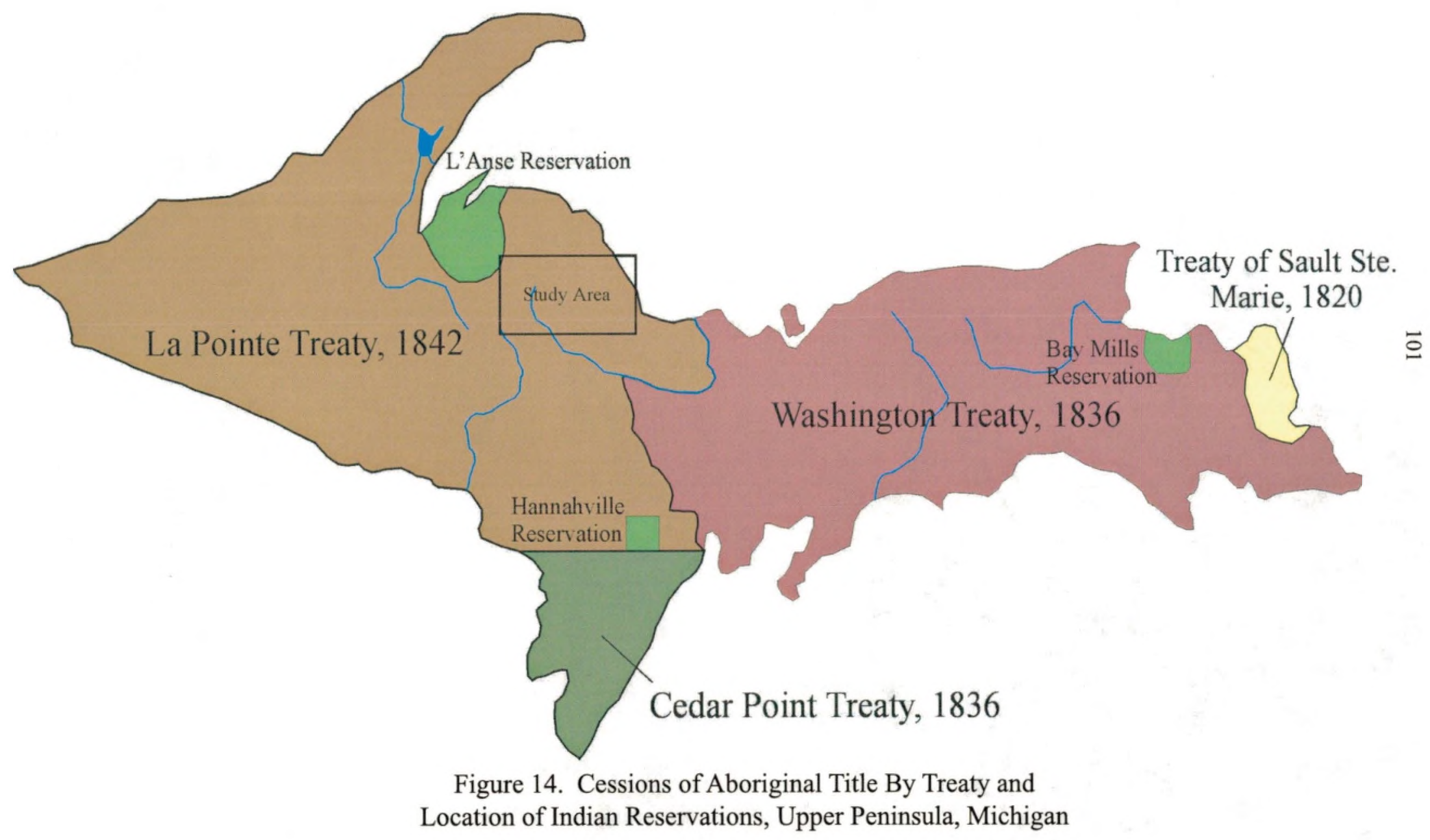


Pointe). The title is misleading because the Chippewa Tribe never functioned as a coherent political entity; the treaty was in actuality concluded with numerous and different bands of Anishnabeg. ${ }^{54}$ The reasons for the simplification of title used by the American government to quantify tribes stemmed from the confusing aspects of Indian hierarchy. Individual sovereignty was strong among the tribes who descended from the Anishnabeg and group decisions were by consensus; decision making took place in the context of families that composed numerous bands. Agreement among the bands required laborious discussion, however, once a general consensus was reached no minority opinions were allowed. Dissenters often simply refused to sign. Because there were limited ways of delegating authority within Indian society, large numbers of Indians assembled for treaty negotiations. Numerous Indians were able to negotiate on the basis of small bands that represented individual familial interests. Within the logic of political sovereignty and treaty making of the American political system, treaties were more easily and comprehensively concluded with large coherent political entities, however, between Lake Superior and the Mississippi River a very large number of autonomous political entities existed creating a confusing and difficult situation for land transfer. ${ }^{55}$

The commissioner on the part of the United States in the negotiations of the Treaty of La Pointe was Robert Stuart. ${ }^{56}$ Stuart, the former chief superintendent of the American Fur Company, replaced Henry Rowe Schoolcraft as the superintendent of Indian affairs in Michigan in the early 1840's. ${ }^{57}$ His position was within the Federal Commission of Indian Affairs and he was instructed by this office to initiate a treaty with the Indians for their land west of the Chocolay River extending to the present day locality of Duluth. As to the removal of the Anishnabeg from the land Stuart's instructions were vague, stating: "It is not likely that it will be necessary for them (the Anishnabeg) to remove for a considerable time, but as that period is uncertain, their removal and their obligation to go, it shall be stipulated, shall be at the pleasure of the President, so that when our policy shall require it they can be displaced. The mines that are one of the objects of the cession will be opened probably very soon, under such laws at it shall be the pleasure of Congress to pass on the subject...there must, therefore, be a stipulation 
that they will remove at once after requirement from such particular parts of the ceded territory as we shall elect to use."

Supplied with money, and the authority to delegate a land transfer, Robert Stuart opened the treaty proceedings at La Pointe on September $29^{\text {th }}, 1842$ by greeting the Indians, and stating: "I am happy to shake hands with so many of my old friends, and very glad to find them all well -- last winter I visited your Great Father at Washington, and talked with him about your circumstances -- he knows that you are poor, that your lands are not good, and that you have very little game left to feed and clothe your women and children -- he therefore pities your condition, and has sent me here to see what can be done to benefit you..." Stuart went on to say: "By the treaty you made with Governor Cass at Fond-du-Lac in 1826, you granted the right to carry away any minerals which might be found on your lands so that they are no longer yours; and the whites have been asking your Great Father to give them permission to take away all they can find, but your Great Father wishes first to make a new treaty, and pay you well for these lands and minerals; he knows you are poor and needy, and that you could be more comfortable by getting a little money, goods, provisions, and tobacco -- also farmers to show you how to cultivate the earth, carpenters to aid you to build your houses, and some more blacksmiths to mend your guns, axes, and other things you need, and something for schools that your children may be taught to read and write like the whites...some of you (the Anishnabeg) have expressed a desire to treat by bands and others to keep reservations, but I cannot sanction either, you Great Father will not treat with you as bands but as a nation... you know that treaties are often made when whole bands are absent, which could not be but on the principle that all your lands are common property, and the majority of the nation sell or not as they please..."59 In exchange for the fifteen million acres of land the government was interested in acquiring through the Treaty of $\mathrm{La}$ Pointe, Stuart offered money, goods, and services to go to the Indian tribes. The Anishnabeg Indians present deliberated on the treaty from September $29^{\text {th }}$ until the $4^{\text {th }}$ of October, and during this time the traders reminded the Indians of the debts they owed, while Stuart implied to the Indians that if they did not come to a quick decision 
concerning the transfer of land, the American government would be reluctant to meet with them again soon. ${ }^{60}$ Finally, the Indians signed the treaty.

The U.S. agreed to pay the bands of Anishnabeg, drawn together as the Chippewa Tribe, $\$ 12,500$ annually for twenty five years, with $\$ 10,500$ worth of goods, and $\$ 2,000$ in provisions and tobacco. The Treaty of La Pointe was constructed after the change had occurred within the American political policy from the Removal to the Civilization Policy. This is expressed within the provisions of the treaty allowing for small plots of reservation land and in services and education aimed at allowing Indians to integrate to American ways. Two thousand dollars was made available to the bands of Anishnabeg for the support of two blacksmith shops, including the pay of the smiths and assistants as well as the cost of the iron, steel and other tools. One thousand dollars was provided through the treaty to pay two farmers to teach the Indians modern farming techniques; twelve hundred dollars went to pay for the services of two carpenters and $\$ 2,000$ was provided for schools to augment the education of the Indians. In addition to providing for the money to support these services for the Indians, $\$ 5,000$ was set aside as an agricultural fund. The half breed relations of the bands signing the treaty received $\$ 15,000$ from the agreement. ${ }^{61}$

As a major part of the Treaty of La Pointe, $\$ 75,000$ was provided to pay the Indian debts within the ceded district. The amounts owed to each trader were examined and decided upon by Robert Stuart, himself only a few years removed from the fur trade and the American Fur Company, a few of the claimants being former associates of his within the company. The amounts paid to the fifty three claimants varied from the smallest claim of $\$ 6.46$, to the claim of John Jacob Astor, a colleague of Robert Stuart's in the American Fur Company who received just under $\$ 38,000{ }^{62}$

The employees of the American Fur company and other traders of the area played a critical role in the accomplishment of the Treaty of La Pointe. The 41 Indian sachems who signed the Treaty of La Pointe understood very little of the American juridical process and they were reliant exclusively upon the traders for explanations concerning the aspects and results of the treaties. ${ }^{63}$ The proceedings of the treaty were also translated 
into the language of the Indians by the traders. The commissioner of the treaty, Robert Stuart and his secretary, John Hulbert were both formerly associated with trade to the Indians. ${ }^{64}$ Twenty one of the fifty three claims for satisfaction of Indian debts named in the treaty were set forth by men who were present and listed as witnesses for the signing of the treaty. ${ }^{65}$ Of the $\$ 75,000$ set aside for the payment of these debts, $\$ 71,769$ went to men who witnessed the signing; a whopping $96 \%$ of the money. ${ }^{66}$ The traders who, in many cases, were the key to the completion of the land transfer, profited the most directly from the realization of the Treaty of La Pointe.

Writing of the land that the American Government had acquired the rights to for a pittance after the successful conclusion of the treaty negotiations, Stuart proclaimed: "...the mineral district is extensive and valuable; the copper ore is said to be of the purest quality. Silver ore has been found between Lake Vieux Desert and Trout Lake; ... the fisheries for Trout, Whitefish and Siquet, along the shores and islands of Lake Superior may be carried to almost any extent, and must at no distant period, become a considerable source of revenue to our citizens. Much of the soil now purchased is reported...to be of excellent quality." 67

\section{The Anishnabeg View of the Treaty of La Pointe}

The reasons why the Indians signed treaties giving up their title to the land so integral to their way of life were numerous. After the War of 1812, an early wave of squatters began moving into the Upper Peninsula in greater numbers. Most of the squatters were in search of copper on the Keweenaw Peninsula, and became a part of the earliest mineral rush in the United States. The squatters, hoping for pre-emption rights, represented the tip of an iceberg of settlement that became more difficult for the Indians to deny with each passing year. The shear numbers of squatters and prospectors forced the Indians to take action in the hope of preserving some portion of their way of life, and treaties, defined in many cases by the traders the Indians knew and trusted, seemed the only way of securing permanent rights with the influx of newcomers. Some Indians perceived that the skills, education, and agricultural expertise offered by the treaties were 
necessary to compete in the new order. The Treaty of La Pointe held out inducements in the form of money, land use concessions, and education while providing a way to destroy debts incurred with the traders.

It cannot be ignored, however, that the Indians were ignorant of many of the ways in which the modern world worked. The Treaties were not completely explained to the Indians and implicit in all the interactions was a threat of force that the government could call on at any time. The use of liquor was often part of the process, which added further to the confusion of the process, making it into a sometimes chaotic affair, instead of a sober, systematic discourse between equal parties. The influence of the traders as subagents for the government, interpreters, and capitalists was critical in gaining the acquiescence of the Indians. ${ }^{68}$ Since property was viewed so differently by Indians and European-Americans the treaties were understood very differently by the respective signers and often the Indians believed that, although they had signed a treaty, they had given up none of their most important hunting and gathering privileges on their land. They intended to keep living on the land much as they had before, gathering from the ecological supply of nature. Many of the Anishnabeg believed that the Treaty of La Pointe had been only a cession of the timber and mineral rights to the land. In 1864 a petition of grievances sent to the Bureau of Indian Affairs written by the Anishnabeg of the area stated: "My Father, I understand you to say that you want the mineral, well then I will comply with the wish of our Great Father in asking me to sell him the minerals which he wants. I do not give you the land. It is the mineral only that I sell if there is any to be found on my land." ${ }^{\prime 99}$ Another petition stated: "So the Father, our Great Father, requests me to sell him my Pine timber...very well, I will sell him the Pine timber as he requests me to. From the usual height of cutting a tree down and upwards to the top is what I sell you, I reserve the root of the tree."70 The Indians did not conceive of property being bought and sold. Only the products of the property were transferred within their economic system. Some Anishnabeg could not conceptualize the transfer of land and planned on continuing their way of life after the European-American settlers had taken what they wanted and then moved on. This notion was impossible once the land was 
transferred to the government, and then sold to individual interests which by legal right controlled everything on a particular tract of land, with joint usage inconceivable. ${ }^{71}$ The process was slow, however, it was inexorable and although some Indians surreptitiously continued their way of life on the small parcels of land unsold to individuals, and on the Federal and State forests and large land holdings of timber and mining interests, thier way of life had become part of a past era.

\section{Conclusion}

By the 1850 's, with the opening of the Soo Locks and the beginning of the construction of the railroads that would connect the iron mines and Lake Superior, the wilderness of the Marquette Range became a settled landscape. Parcels of land were being acquired and bounded, and the resources of the land were beginning to be extracted for profit. The European-American settlers to the Range, with the strong support of the American government, which had opened the land up for settlement, had established a capitalist system of production that was beginning to redefine the natural features of the Range. Over the next 50 years, this process of redefinition would accelerate in a profoundly transformative way.

Within the dialectical relationship of the cultural and natural systems, as American society was radically changing the natural world, the environment was having an effect on the economies, class systems, political organizations and cultural rituals, as well as, the spatial distribution of transportation and settlement patterns of the settlers. In chapter two of this work, and coming up in chapter four, I have attempted to show the ecological and geological changes that occurred on the Marquette Range through the transition from Anishnabeg to American Capitalist society. I have also attempted to show how these natural features affected the settlement process and the society of the Range. Within this past chapter I have shown how, and why, this change occurred. The transition from Anishnabeg to European-American culture had an affect on the environment of the Range, but was also brought about through the human relationship to the environment. By modifying their mode of production, both willingly and because 
they were forced to, the Anishnabeg began to relate differently to their natural surroundings and were, eventually, forced off of their land as a result.

For the estimated 100 billion board feet of timber, 150 billion tons of iron ore, and 13 billion pounds of copper that were removed from the 19 million acres of land acquired by the American government through the treaties of Washington (1836), and La Pointe (1842), the Anishnabeg received only a few thousand dollars, odds and ends of equipment, a few thousand acres of reservation, and some debts repaid. ${ }^{72}$ Progress had arrived on the Marquette Range with the new human order extraordinarily effective at modifying their natural surroundings. The geological and ecological systems were forever to be changed for the profit of American capitalist society. 


\section{END NOTES}

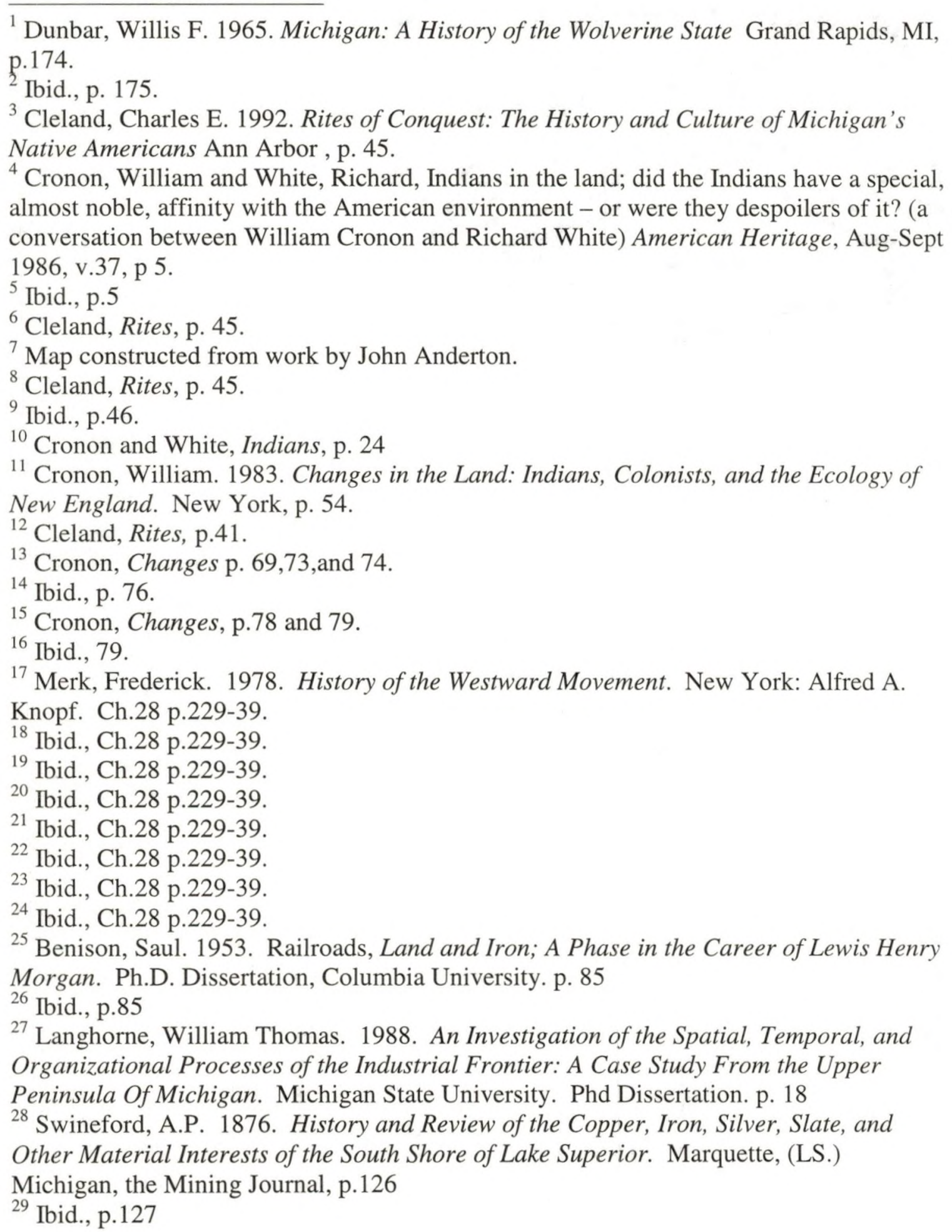


${ }^{30}$ Ibid., p.127 Swineford reports that the remainder of the land granted for the construction of the canal, 487,717 acres, went toward claims of pine land in the lower peninsula of Michigan.

${ }^{31}$ Ibid., p.127 In 1864 Horatio Bigelow stated in: St Mary's Canal Mineral Land Company. Reports upon the Value of the Company's Lands Located in the Iron Region of Lake Superior, County of Marquette, State of Michigan. 1864. Wright and Potter, Boston. p.5, that the St. Mary's Canal Mineral Land Company owned 33,000 acres of land in Marquette County; 18,000 of these acres according to Bigelow were valuable mineral lands. The very next year J.W. Foster reported on more than 37,000 acres owned by the Iron Cliffs company which were purchased from the St. Mary's Company. ${ }^{32}$ Figure scanned from Foster, J.W. 1865. The Geology and Metallurgy of the Iron Ores of Lake Superior: Being a Report Addressed to the Board of Directors of the Iron Cliffs Company New York, WM. C. Bryant and Co., Printers.

${ }^{33}$ Dunbar, Michigan, p. 174

${ }^{34}$ Ibid., p. 174

${ }^{35}$ Cleland, Rites, p.199-203.

${ }^{36}$ Ibid., p. 199.

${ }^{37}$ Ibid., p. 201.

${ }^{38}$ Ibid., p. 202, 203.

${ }^{39}$ Ibid., p. 203.

${ }^{40}$ Cronon and White, Indians, p. 23

${ }^{41}$ Ibid., p. 23

${ }^{42}$ Ibid., p. 23

${ }^{43}$ Ibid., 24

${ }^{44}$ Ibid., 24

${ }^{45} \mathrm{I}$ acquired this quote from a poster on display at the Northern Great Lakes Visitor Center, located just west of Ashland, Wisconsin, and operated by USDA Forest Service, National Park Service, and State Historical Society of Wisconsin.

${ }^{46}$ Cleland, Rites, p. 209.

${ }^{47}$ Letter From Governor Cass, of Michigan on the Advantage of Purchasing the Country Upon Lake Superior where Copper has been Found: Addressed to the Hon. Thomas H. Benton, of the Senate. $18^{\text {th }}$ Congress, $2^{\text {nd }}$ session, Published January 21, 1825.

Washington: Printed by Gales and Seaton. p.3

${ }^{48}$ Dunbar, Michigan p.174.

${ }^{49}$ Ibid., 175.

${ }^{50}$ Constructed from a map in Dunbar, Michigan p. 176.

${ }^{51}$ Treaty with the Chippewa, 1842 signed at La Pointe in: Kappler, Charles J. (Clerk to the Senate Committee of Indian Affairs). 1904. Indian Affairs, Laws and Treaties, Volume II (treaties) Washington, p. 543-545.

${ }^{52}$ Carter, James L. and Rankin, Ernest H. (editors). 1970. North to Lake Superior, The Journal of Charles W. Penny, 1840 The John M. Longyear Research Library, Marquette MI, p.60

${ }^{53}$ Ibid., p. 62 and 63

${ }^{54}$ Cleland, Rites, p. 205. 
${ }^{55}$ Ibid., 205, 206.

${ }^{56}$ Treaty with the Chippewa, 1842 , p. 543

${ }^{57}$ Cleland, Rites, p. 179.

${ }^{58}$ Johnston, Thomas A. 1975. Indian Treaties of the Upper Peninsula: Broken Promises and Forgotten Obligations Master of Arts Thesis, History Department at Northern

Michigan University, p. 40

${ }^{59}$ Ibid., p. 41

${ }^{60}$ Ibid., p.42

${ }^{61}$ Treaty with the Chippewa, p. 544.

${ }^{62}$ Treaty with the Chippewa, p. 544

${ }^{63}$ Cleland, Rites, p. 210.

${ }^{64}$ Ibid., 177.

${ }^{65}$ Treaty with the Chippewa, p. 545.

${ }^{66}$ Ibid., p. 545.

${ }^{67}$ Johnston, Indian Treaties, p. 43

${ }^{68}$ Cleland, Rites, p. 209, 210.

${ }^{69}$ Excerpt from grievances from Ojibway Bands to Commissioner of Indian affairs in Washington D.C., 1864. The quote comes from a display present at the Northern Great Lakes Visitor Center.

${ }^{70}$ Ibid.

${ }^{71}$ Cronon, Changes, p. 58,68.

${ }^{72}$ Wrone, David R. Economic Impact of the 1837 and 1842 Chippewa Treaties From a poster at the Northern Great Lakes Visitor Center. 


\section{CHAPTER IV. MINING ON THE MARQUETTE RANGE}

Introduction/Copper and the Southern Shore of Lake Superior/The Pre-Major Settlement Marquette Range/ The Discovery of Iron Ore/The Geologic Features of the Marquette Range/ The Effect of the Geologic Features on the Mining of the Marquette Range/ The Open Pit, Surficial Workings/Early Transportation on the Marquette Range/ The Underground Workings/Conclusion

\section{Introduction}

The first detailed, scientific descriptions to be written of the natural features of the Marquette Range, the rocks, water, trees, and animal life, came from the first expeditions that skirted the Range beginning in the early $19^{\text {th }}$ century. The accounts from these expeditions that traveled through territory not yet in the possession of the United States, detail a remote and wild land with immense stands of trees occupying a terrain of rugged relief and complex geology. The accounts reveal what the Marquette Range was like prior to man settling there in great numbers, carving his wealth out the land's resources. Over time, the ecological abundance and geologic complexity, containing massive amounts of timber and mineral wealth, would play an immense role in the definition of the settlement of the area. As the natural features influenced the settlement, they in turn would be strongly affected by the resource extractive society that quickly multiplied on the Range. In the early descriptions written by the first explorers, prospectors and scientists to the Range, we read of the natural features that would be completely changed while they defined the society that would rework them.

Indians have lived on the Marquette Range since the end of the last glaciation, and at least one band of Anishnabeg called the Marquette Range their home. Beginning in the $17^{\text {th }}$ century, Jesuit Missionaries traveled the region and wrote of their experiences with the Indians and the land of the Lake Superior wilderness. ${ }^{1}$ The massive iron beds that would greatly flavor everything that occurred on the Range remained unknown to Europeans until the mid- $19^{\text {th }}$ century, however the amazing and unique copper deposits 
on the Keweenaw Peninsula were recognized by those first missionaries, who wrote of them and inspired others to travel into the remote land. Traders soon followed the religious men in search of the capital that animal pelts could provide, setting up remote trading posts through the land and forging relationships with the aboriginal peoples.

The trip at this early stage, into the densely forested northern wilderness was not an easy one. In small crafts, on the vast waters of the largest fresh water lake in the world, the travelers had to brave hundreds of miles of mostly rugged shoreline, passing only very scattered and small trading outposts, missions, and Indian villages. The rapids at Sault Ste. Marie mandated, by forcing a portage, that only small boats be sailed on Lake Superior and large sandstone cliffs bounded the lake for long stretches, preventing the landing, in harsh weather, of the small crafts used.

The trip, though dangerous, must have also been truly gorgeous. Vivid descriptions from the period discuss the immense land and the beauty of the stars and northern lights of the nights there. ${ }^{2}$ Between Detroit and Copper Harbor immense forests on the shore were framed between the sky and pure water containing unfathomable numbers of fish. Each stream and river that poured out of the dense, old growth forest was clean and unencumbered in its route to the lake. When the early missionaries, traders, and explorers passed beyond one of these clean and unencumbered rivers that ran into Lake Superior, the Chocolay River, they were met with a significant topographical and geological demarcation. Here the flat lying and mostly undeformed sandstones of the eastern end of the Upper Peninsula became very complex, more rugged Precambrian igneous and metamorphic rocks. The travelers at this point passed from the Paleozoic and Keweenawan sandstones to the Archean and Proterozoic rocks of the Marquette Range.

The complex Precambrian strata of the Marquette Range that the early explorers encountered contained very large deposits of iron ore. This ore provided the reason for the first settlers to arrive on the Range, and for the first acquisition of property in the region. Two types of ore were found in abundant supply within the complex rocks of the Range: hard and soft ores. The natural distribution of the hard and soft ores, determined 
by over a billion years of geologic processes, determined the nature of the mining and the success of the mines on the Range.

The hard, resistant ore was usually found near the surface of the Range and, because of its location, was the first type of ore to be mined from the Range. The ore was first cleared of its overburden, then blasted out of place. Men broke the blasted pieces up and loaded it into carts for transportation. The early mining actives were very similar to a quarrying operation, and the abundant supply of surface ore and ease of extraction allowed numerous companies to mine the ore of the Range at a profit. Transportation improvements on the Range, including the completion of a railroad from Marquette to the mines surrounding Negaunee/Ishpeming, also helped to make the iron mines and the entire community prosper economically.

The second type of ore mined in quantity on the Range was a soft ore that was mostly found deep beneath the surface. Although the surface deposits were extensive, they reached exhaustion beginning in the 1870's, and as they were depleted certain mines continued their operations by following the ore beneath the surface. The transition between surface and underground work was usually not a black and white progression; many mines on the Range had both surface and shaft mining occurring in conjunction at their locations, with shafts being dug before the surface ore was used up. Underground mining was an expensive and dangerous proposition and the haphazard, spontaneous mining that had determined much of the surface work gave way to the systematic, detailed planning of shafts and drifts beneath the surface to get at the underground ore. The workings in the soft ore mandated extensive supporting structures such as rock pillars purposefully left in place and not mined or timber frames, which necessitated the cutting of large amounts of timber, further adding to the tax on the natural systems.

As time passed, the numerous companies of the open pit period on the Range gave way to a select few wealthy and well organized companies that delved beneath the surface to continue the extraction. The settlements of the Range have always been closely tied, in a spatial sense, to the centers of ore extraction. During the initial open pit phase of mining many communities were spread along the Range, mirroring the diversity and plentitude of the mining operations, however, as consolidation of mining occurred 
with the progression into shaft mining, those diverse and numerous communities began to concentrate in large population centers.

Among the numerous factors that have affected the history of the Marquette Range, iron and its relationship to a capitalist society is the most important. The presence of the iron was why Marquette arrived into existence, and was the driving force behind it rapid growth. The valuable commodity created wealth for the residents of the Range, and, hence, allowed all other aspects of existence. Within the ancient rocks of the Range is written the history of the $19^{\text {th }}$ century civilization of the Range. As that civilization flourished, a parasite of the naturally provided iron deposits, its influence became extensive. The civilization reworked the deposition, displacing great quantities of rock and removing equally great quantities of ore. To aid them in the removal and processing of the ore the civilization called upon many other parts of the natural environment, reworking these systems in equally profound ways.

\section{Copper and the Southern Shore of Lake Superior}

Beginning with the first human habitation of the Lake Superior region, copper in its native state and in abundant supply was found on and very near the surface of the Midcontinent Rift igneous and sedimentary rocks of the Keweenaw Peninsula in the Upper Peninsula of Michigan. The copper was attainable and abundant enough that, at a very early point, the aboriginal people of the area began to use the mineral for ornaments and trade. When early Jesuit Missionaries arrived in the region, beginning in the $17^{\text {th }}$ century, they became the first European Americans to see this native mineral and also the first to communicate the potential resources of copper to the outside world. As early as 1636, a book was published in Paris that mentioned the Keweenawan copper, and the reports and relations of the Jesuit missionaries in the mid- $17^{\text {th }}$ century discuss the Indians' knowledge of the localities of and their uses for the ore. By the late $18^{\text {th }}$ century a few very small mining operations had begun in the area, with most failing to gather anything more than cursory amounts of the metal. ${ }^{3}$

When the control of the Lake Superior region was transferred to American hands, reports of the copper in the area were part of the inspiration behind several expeditions 
that ventured through the area. In 1819, Henry Rowe Schoolcraft accompanied a government expedition along the south shore of Lake Superior as geologist and mineralogist to the expedition. Schoolcraft brought back samples of the copper, and wrote of the geology of the area. Four years later, Major Stephen Long passed along the north shore of the lake also bringing back information of the mineral wealth. A third expedition set out in 1830, under Lewis Cass, seeing on the trip the Ontonagon Boulder, a very large piece of pure native copper near the Ontonagon River west of the Keweenaw Peninsula. The expedition contained Schoolcraft and also Douglass Houghton, who would head the Michigan Geological Survey upon its construction several years later. ${ }^{4}$

The initial detailed scientific exploration of the Keweenaw Peninsula, as well as the area of the Marquette Range, began a few years later with several expeditions led by the recently named Michigan State Geologist Douglass Houghton, starting in $1840{ }^{5}$ Houghton spent much of his time in the analysis of the copper deposits of the Lake Superior area, and his report on this area to the Michigan State Legislature in 1841 was one of the important factors contributing to the first mineral rush in the United States, causing a great deal of land speculation in the Lake Superior area. Houghton's report was based on his ten years of field experience in the region; by 1841 he had traveled the south shore of the lake by boat five times, on each of these journeys passing by the Marquette Range. ${ }^{6}$ The descriptions written of the Marquette Range by Houghton and his assistants, the first scientific analysis of the area, provide a pre-European American settlement baseline that allows for an analysis of the change of the natural features occurring due to the subsequent major settlement of the land. Their descriptions detail the topography and forests of the Range as they were in 1840 and discuss the geology found near the shore. With the exception of the copper country on and around the Keweenaw Peninsula the Houghton expeditions remained near to the shore of the lake, and although Houghton witnessed traces of iron ore in sediments near the lake, he was not aware of the ore in quantity until William Burt returned to Detroit and informed him of the discovery of iron outcrops near Teal Lake, in the fall of $1844 .^{7}$

The Lake Superior area of 1840 that Houghton and his assistants described in their reports was a remote, and sparsely populated, vast expanse of land. Indians were 
present, however their settlements were itinerant and small; only at certain times of the year did the Indians gather in large groups, in anything that could legitimately be called a settlement. The limited European-American settlement of the area was almost wholly related to the fur trade and missionary work, consisting of several very isolated and selfreliant trading posts and missionaries.

At Sault Ste. Marie, the canal traversing the rapids present between the lakes, roughly a half mile wide, running for a quarter of a mile, dashing, foaming and roaring comparable to Niagara Falls in noise, would not be built for another 15 years, so that everything needed for expeditions on Lake Superior had to be portaged. ${ }^{8}$ The ships built above the falls were small brigs or schooners that were not always well suited for sailing on the violent and often unpredictably dangerous waters of Lake Superior. The American Fur Company had its headquarters at Sault Ste. Marie which consisted of between twenty and thirty mostly log houses having a neat appearance. In addition to the trading post, the picketed Fort Brady, built in 1820, maintained a garrison of United States troops at the Sault. Across the river, in land controlled by the British, was a smaller village consisting of a few whitewashed log cabins housing the Hudson Bay Company, a windmill, and both Episcopal and Baptist missions. ${ }^{9}$ Much further west of the Sault, at L'Anse, on the eastern side of the Keweenaw Peninsula, was another American Fur Company settlement consisting of a log house, a storehouse and a barn. A Baptist mission of a dozen neat huts made of $\log$ and bark was also present at L'Anse. Further west, on Madeline Island in the Apostle Islands of what would later become Wisconsin, the American Fur company had a third trading post established at La Pointe. These comprised the EuropeanAmerican settlements of the south shore of Lake Superior in 1840. Two or three transient fishing camps existed, copper prospecting had started on the Keweenaw Peninsula, and scattered aboriginal peoples subsisted, however, all the rest of this vast area was uninhabited. ${ }^{10}$

The early method of travelling along the southern shore of Lake Superior involved a sometimes dangerous journey in a small boat. Westward from Sault Ste. Marie toward the Marquette Range, the southern coast of Lake Superior borders upon broad beaches of sand and gravel which led, in the 1840's, to hills containing Norway 
pines, spruce, hemlock, cedar and birch. The beaches west of Whitefish Point leading into the bay of Grand Marais provided prolific fishing grounds for early travelers to the area, and west of the Grand Marais steep, uniform cliffs stretching for nine miles along the shore rise out of the lake, 200 feet in height, leading into the Grand Sable Dunes. ${ }^{11}$

The views along the southern shore of Lake Superior were beautiful and inspirational, but also very dangerous for early travelers. Just beyond the steep rise of semi-consolidated sand topped off by the extensive dunes and sparse vegetation of the Grand Sable Dunes, Au Sable point juts out into the southern reaches of the lake. A layer of Jacobsville sandstone extends far out into the lake just beneath the water's surface, giving the lake an anomalous greenish appearance and producing a natural hazard to ships travelling near the shore. The beach near the point, where there is a lighthouse present today, is littered with dozens of wrecks that strayed too close to the shore. Beyond this point and Twelvemile Beach start the cliffs of the Pictured Rocks Lakeshore, which rise out of the lake to a maximum height of between 80 and 250 feet and expose gorgeous cross sections of sandstone. The cliffs stretch over an area of twelve miles to near what is now Munising, and for the early travelers provided only randomly punctuated beaches for safe haven from quick moving storms. Of the area Henry Rowe Schoolcraft wrote in 1820: "We had been told, by our Canadian guide, of the variety in colour and form of these rocks, but were wholly unprepared to encounter the surprising groups of overhanging precipices, towering walls, caverns, water falls, and prostrate ruins, which are here mingled in the most wonderful disorder, and burst upon the view in ever varying and pleasing succession." 12

\section{The Pre-Major Settlement Marquette Range}

Beyond the Grand Sable Dunes and the Pictured Rocks, beyond Grand Island and the deeply incised hills that surround what is now the city of Munising, near where the Chocolay River flows into Lake Superior, flat lying and uniform, undeformed Keweenawan and Paleozoic sandstones meet the heavily reworked metamorphic and igneous rocks of the Penokean Continental Margin. The boundary of the two rock systems is clearly marked on the landscape and was a major landmark for early explorers 
visiting the area. Prior to the Treaty of La Pointe in 1842, the Chocolay also represented the boundary between officially ceded territory of the U.S. and that of Indian Lands belonging to the Anishnabeg.

Generally, the country of the eastern Upper Peninsula was thought to be unimportant when compared to what lied to the west of it. On one of his expeditions to the area, Houghton described the Paleozoic rocks of this area as simple, involving only a few obscure areas. ${ }^{13}$ Beyond the Chocolay River, however, things changed considerably and the river marked where the potential for mineralization began, and, hence, became the starting point of true interest for the early geologists and prospectors traveling in the region. Writing on June $16^{\text {th }}, 1840$, Charles Penny, an assistant to the 1840 Houghton expedition, wrote of crossing the boundary between the two rock systems: "We are now in a region where the geologists begin to work. We have parted company with the sandstone, and got among hills as high and as rocky as New England."14

The Houghton expedition of 1840 , on their way to the Keweenaw Peninsula to analyze the copper mineralization present there, camped for several days in the area of the Marquette Range, collecting samples of the rock and writing descriptions of the terrain. At one point the party climbed what was later to be called Mt. Mesnard, and from the glacially grooved Mesnard quartzite outcropping on the ridge surveyed the landscape surrounding them. Below them Iron Bay, later to be called Marquette Bay, was a completely undeveloped shore. To the east were the heavily forested, flat-lying sandstones of the country they had just traversed and to the west were the numerous ridges of the likewise heavily forested Marquette Range and Huron Mountains. From the knobs of quartz and granite of the beginning of the Marquette Range, Bela Hubbard, a second assistant to Houghton on the trip, obtained what he described as beautiful and very interesting views of the country which had become hilly. Looking east from high knobs on the Range Hubbard noted that the change from the flat sandstone country to the hilly older rocks was immediate. His view extended to the extreme easterly termination of the Pictured Rocks, beyond Grand Island to the Grand Sable Dunes, nearly 100 miles distant. He stated: "This view embraces a track lying in transverse broad steps of the sandstone rock." 15 In the opposite direction, looking toward the west and the Marquette 
Range, Hubbard commented: "the change is immediate to a country of rolling hills, with high primary knobs apparently dispersed with little order, but with a closer examination are found to be in distinct ranges at some 2 or 3 miles distant, with intervening smaller ridges filling up the interval." 16

Douglass Houghton joined his assistants in commenting on the abrupt nature of the topographical change between the two rock systems, and also noted the corresponding change in the geology stating: "The widely different topographical features of the easterly and westerly portions of the northerly portion of the upper peninsula would lead the most casual observer to infer that the geologic features of the different districts would be equally distinct, and in this he would not be disappointed."17 The geology, in his view, became exceedingly complex and difficult to understand west of the Chocolay, with the district made up of primary, trap and metamorphic rocks with sedimentary rocks in the valleys and the outer boundaries. The complex geology, according to Houghton, contained, "all the rocks that are rendered so highly interesting by their mineral riches." ${ }^{18} \mathrm{He}$ described the country as made up of a series of east-west trending ranges and contrasted the unbroken dense forest of the land east of the Chocolay River with the abrupt knobs and escarpments of the Marquette Range, difficult to ascend and destitute of timber. ${ }^{19}$

\section{The Discovery of Iron Ore}

There is no record of the knowledge of the presence of the iron ore of the Lake Superior area being communicated from the aboriginal inhabitants of the area to the first European explorers and missionaries to the area. Unlike the copper found in the native state, the iron ore outcrops of the area were utilized by aboriginal peoples only as landmarks and religious sites. The iron was not traded by the Indians, nor did they smelt it to form pig iron. Although great amounts of high grade iron ore were located near the surface on the Marquette Range, and outcropped in large, impressive and anomalous, uniquely banded deposits of metallic appearance, specimens of the outcrop revealed no particular unique value to the Indians. Iron in its native state, an impressive and interesting looking rock, serves no immediate purpose to those unable to smelt it, so the 
Indians had little reason to transport the ore from its natural location, nor expect that the arriving European-Americans would find it of value. Their admiration of the deposits was in situ admiration, and though the outcrops seemed to have played a religious role in the Indians' culture, it played no part in their economic existence. Because of the failure of the knowledge of the outcrops to be transferred, the early literature concerning the area does not refer to iron; hundreds of years passed between the missionaries' initial descriptions of the copper of the area and the discovery by European Americans of the iron deposits.

For early European-American travelers to the region, nearly all travel occurred by boat on Lake Superior. Travel was slow in the dense forests of the Upper Peninsula, and since there was no major habitation in the interior lands there were no reasons to diverge from the shoreline. At no point do the iron deposits of the Marquette Range outcrop near the shore, nor are they within view from the lake's shores. Cursory analyses of the area revealed nothing of particular interest, and it was not until thorough, scientific observations were made of the area that its value began to become apparent.

The first mention of the possibility of iron existing in large quantities within the rocks of the Marquette Range came from the descriptions of the area by Douglass Houghton. The expeditions only briefly skirted the Marquette Range, however traces of iron were located near the lakeshore. In one of his works, Houghton addressed these traces by stating that iron was disseminated in the rocks of the southern shore of the Lake. ${ }^{20}$ The expeditions did not come into direct contact with the immense iron ore beds, and the traces they saw were not of sufficient quantity to be stated in Houghton's reports as important. ${ }^{21}$ It is probable that, during this time, no Indian tradition regarding large deposits of iron ore came to Houghton's knowledge. ${ }^{22}$ Only copper was found in abundant enough supply for Houghton to state its importance to the future settlement and prosperity of Michigan, however, he also acknowledged extensively at the time the limited nature of the terrain he had covered and his understanding of the complex geology. ${ }^{23} \mathrm{He}$ specifically stated that the area inland from the shore should be more closely analyzed, with the fulfillment of his desire realized a few years later when 
Houghton sent William Burt and a survey crew to the Marquette Range for a more thorough analysis of the area.

During the year of 1843, the young state of Michigan, undergoing financial troubles, decided to withhold the annual appropriation of financial support for the geological survey which had been running under Houghton since 1839. This lack of funding threatened to seriously limit Houghton's geological survey of the Upper Peninsula. Looking for other sources to support his work, Houghton contacted the Federal Government and requested that the linear surveys in the Upper Peninsula conducted by the General Land Office be given an extra allowance of funds per mile to cover geologic observations. The government agreed and in 1844 Houghton took over the contract for completing the linear surveys in the Upper Peninsula, combining the state geological survey and the Federal land survey to accomplish a more thorough geological examination of the district. ${ }^{24}$

In the spring of 1844, William Burt, along with William Ives (compassman), Jacob Houghton (barometer man), H. Mellen, R.S. Mellen, James King and two Indians named John Taylor and Bonnie, began to work in the Upper Peninsula, surveying throughout the summer. On the $15^{\text {th }}$ of September the crew established the $47^{\text {th }}$ township line north on the shore of Lake Superior between the deltas of the Chocolay and Carp Rivers. From there they traveled westward along the east-west line from Iron Bay into the interior of the Marquette Range and camped on the far eastern end of Teal Lake on the night of September $18^{\text {th }}$. The next day while running the survey line south along the eastern side of township $47 \mathrm{~N}$., Range $27 \mathrm{~W}$, the crew noticed very large fluctuations in the magnetic needle of the survey compass within the first mile from Teal Lake. ${ }^{25}$ Upon further investigation the crew discovered rock rich in iron. This was the first recorded discovery of the large deposits of iron. ${ }^{26} \mathrm{~A}$ few days later, on the $21^{\text {st }}$ of September, six inches of snow fell, signifying the end of the field season and the crew eventually returned to Detroit where they informed Houghton of their important discovery. Burt would eventually write of the area after having worked in the Upper Peninsula for several more seasons: "It may be reasonably inferred that not more than one-seventh of the number of iron ore beds were seen during the survey of the township lines; and if this 
district of Townships be subdivided with care in reference to mines and minerals, six times as many more will probably be found. If this view of the iron region of the Northern Peninsula of Michigan be correct, it far excels any other portion of the United States in the abundance and good qualities of its Iron ores." ${ }^{27}$

The first recorded transfer of the Indian knowledge of large iron deposits on the Marquette Range to a European American occurred at Sault Ste. Marie in 1845, when a half Indian native of the area Louise Nolan told a group of men from Jackson, Michigan of the deposits. At this time the discovery of the surveyors the summer before was not widely known and the group from Jackson, consisting of four men named Philo Everette, S.T. Carr, E.S. Rockwell, and W.H. Munroe, were not looking for iron, but rather were on their way to the Keweenaw in search of copper prospects. The prospector's thoughts turned to minerals other than copper only after meeting Nolan, who had traveled to the Range as a boy. ${ }^{28}$ Hearing Nolan's descriptions of anomalous rocks outcropping on the Marquette Range, the group decided to pay Nolan to guide them to the outcrops. The men successfully made it, after a long trip, to Teal Lake, however, once in the area the prospectors were unable to find the outcrops of iron rich material in the thick forest and had to return to Lake Superior, traveling on further to L'Anse where they located another Indian named Marjijesick who eventually took them to the iron. ${ }^{29}$ The outcrop that Marjijesick, an Indian whose clan lived part of the year on the Range, took them to was just west of the section where Burt's survey party had discovered the iron the summer previous. The outcrop was later described by Philo Everette as "a mountain of solid ore, 150 feet high. The ore looks as bright as a bar of iron just broken." ${ }^{30}$ The expedition led the Jackson Mining Company to the first purchase of property for the purpose of iron mining on the Marquette Range, which occurred in September of 1845. After locating the large outcrop south of Teal Lake, in Township 47 N., Range 27 W., section 1 (see Figure 16 for the location of the Jackson Mine labeled as 101), the Jackson Mining Company decided to establish a claim, went directly to Copper Harbor, over a hundred miles away and established Mining Permit 593, one square mile in size, purchased for $\$ 2.50$ per acre from the U.S. Government. Maps of the area had yet to be published, or in some cases even created, so the claim had to be approximated on the very general maps 
available. ${ }^{31}$ During the next few years the Jackson Company began mining at their location and smelting the ore at the Carp River Forge. After the opening of the Jackson Mine it is estimated that only 50 European-American settlers inhabited the Marquette Range. $^{32}$

In the spring of 1846 , members of the Jackson Company were returning to the lower peninsula with samples of the iron from their location when they met Samuel Cassels, an agent for a mineral prospecting company based out of Cleveland. Cassels was also mostly interested in copper prospects, however after he had seen the samples the Jackson men were returning with and heard their stories of the large beds of iron, his interests turned to iron. The men of the Jackson Company spoke freely of their discovery with Cassels because they had decided that a partner with whom to share the high cost of the transportation to the area of the deposits on the Range would be favorable for their interests. After being informed of the deposits, Cassels traveled to the Range and established the second land claim on the Range at another large outcrop of iron ore that would become known in time as the Cleveland Location. ${ }^{33}$ Based on Cassels' findings, the Cleveland Mining Company was formed in 1847 in Cleveland, Ohio. On the second day of April, 1850 the state of Michigan granted a charter of incorporation to the company to engage in the mining, smelting and manufacture of iron. The early activities of the Cleveland company concentrated on land operations, however, the company began mining in the spring of 1854 , and mined 3,000 tons of ore used to make blooms of pig iron. ${ }^{34}$ The next year the company began shipping the ore directly to Marquette, and from there to Cleveland, leading the way for the protocol of the future, when the smelting of iron would give way to the direct shipment of ore to ports on the southern Great Lakes.

The Marquette Iron Company, headed by Robert J. Gravereat and employing Peter White, was the third company to enter into iron mining on the Marquette Range. In 1848 , the company purchased 80 acres of land in section two of T.47N., R.27W, southwest of the Jackson location. The company began mining and smelting ore in 1849 and was the only company to join the Jackson Company in the extraction of ore prior to 1850. The Marquette Iron Company was greatly limited due to the lack of a necessary 
investment of capital and in 1853 sold its valuable mineral property to the Cleveland Company. ${ }^{35}$

The Jackson, Cleveland, and Marquette Mining Companies were the first to establish claims and begin the mining of iron on the Marquette Range. The area was little more than a wilderness when these companies began work here, yet within the next quarter century hundreds of mines would be worked on the Range. As more work was done to extract the ore, a better understanding of the natural features of the area was formed. These natural features, as they were slowly being modified by the settlers, defined the economy and culture of those who were arriving.

\section{The Geologic Features of the Marquette Range}

Throughout the $19^{\text {th }}$ century the location, distribution and nature of the iron ore found on the Marquette Range was to have profound and wide ranging effects on the nature of settlement in the area. The ore would determine the nature of extraction on the Range, and the ruggedness of the land would strongly affect the transportation from the deposits to Lake Superior. The ore's spatial distribution and nature would be the most influential determining factor on who among the many that would follow in the footsteps of the Jackson, Cleveland and Marquette mines found success and failure in the iron of the Range. Figures 15 and 16 on the next two pages show the distribution of all of the iron mines that have existed on the Marquette Range from the Jackson, Cleveland, and Marquette mines of the early 1850's to the Empire and Tilden mines that are still active today. The numbers that coincide with the mine locations on the figures match up to the Im\# category in Table 1 at the end of this chapter. The majority of these mines, as can be seen from the table, were active in the $19^{\text {th }}$ century. The location of each of these mines comes from recently updated and verified Minerals Resource Data System (MRDS) records $^{36}$. In addition to the location of the mines, Figure 15 shows the distribution of the iron formations on the Range, dominated by the Negaunee Iron Formation, and the Digital Line Graphics representation of the modern transportation system of the region. Figure 16 shows the locations of the mines in the Negaunee/Ishpeming/Palmer area along with Digital Raster Graphics 100,000 scale topographic quadrangle data for further 


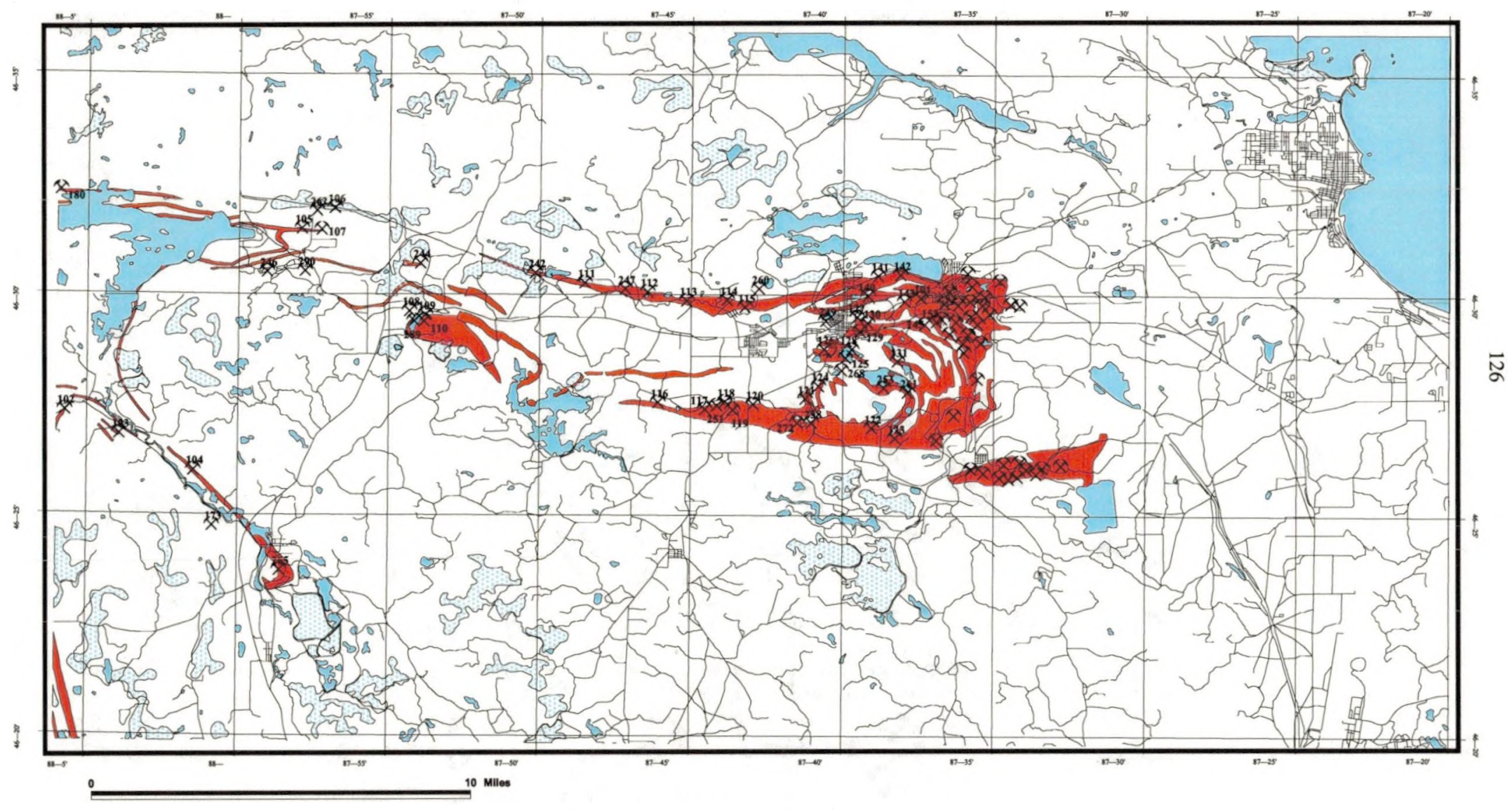

Figure 15. Location of the Mines, Iron Formation, and Roads on the Marquette Range 


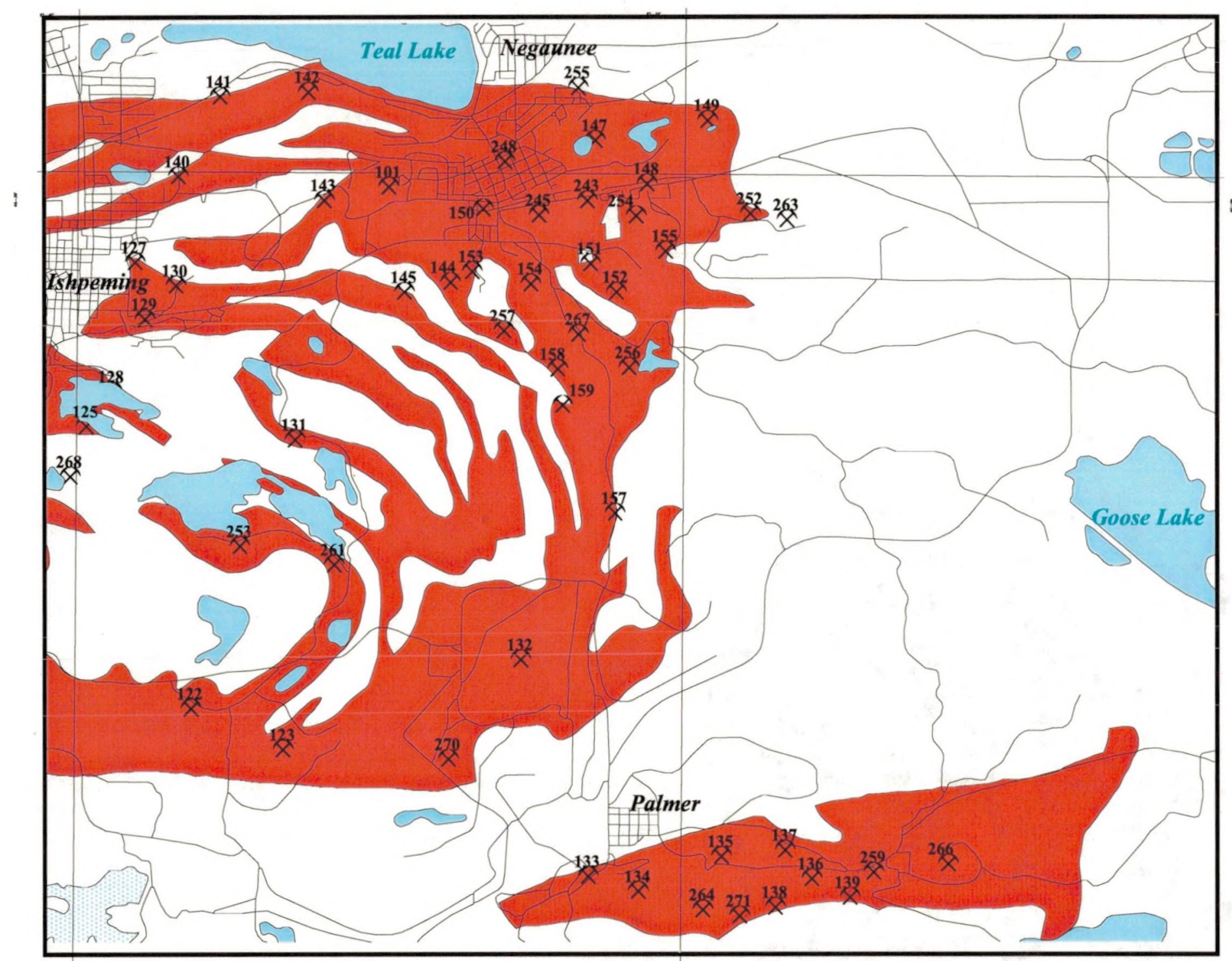

Figure 16. Location of thë Mines, Iron Formation, and Roads in the Negaunee/Ishpeming/Palmer Area 
clarification of the site locations. These figures show that the location of the iron rich rock determined the location of the mines.

The Marquette Range was the first discovered and most easily accessible iron range of the Lake Superior Region, however the high grade ore was at least seven miles away from Lake Superior and the country was rugged and covered with forests of thick vegetation. Foster and Whitney wrote of this inaccessibility in 1851: "Nearly the whole of this area is an unbroken wilderness, interspersed with tangled thickets, almost impassable marshes and inland lakes, which retard the progress of the explorer; and, even along the mountain ranges where the rocks approach the surface, their presence is often concealed by a thick covering of moss. It is only on the precipitous cliffs, or along the beds of streams, that their true characters are revealed." ${ }^{37}$ A detail from their map of the area constructed in 1851, shown in Figure 17, reveals only the beginning of an inroad of civilization into the wilderness of the Range. In the figure, the town of Marquette is referred to as Worcester, its very brief original moniker, and the only structure beyond the town shown is the Jackson (or Carp River) Forge. In 1851, one very rough track or road stretched from the Jackson mine just south of Teal Lake to the Jackson Landing on Lake Superior, providing the means of transporting the ore to the outside world. The red color on the Foster and Whitney map is representative of quartzite found on the Range, with the green representing trappean rocks and the blue limestone. The circles with the arrows represent places where iron was found by Foster and Whitney in the region. The rugged, remote and undeveloped nature of the Range at this time, exemplified by the spare map of these early geologists, was a major determining factor in the lives of the individuals that attempted to carve out a living on the Range.

The Marquette Range consists of a synclinal basin bounded by older rocks on the north and the south. The rocks are collectively known as the Marquette Range Supergroup and consist of a complex basin of metamorphosed, lithified sediments extending in an east-west direction from Lake Superior in the east to Lake Michigamme in the west. North of the Supergroup is a gneissic complex originally made up of volcanic and fine-grained sediments that were highly metamorphosed after deposition. Also to the north is an altered volcanic greenstone belt dated at 2.7 billion years old. 


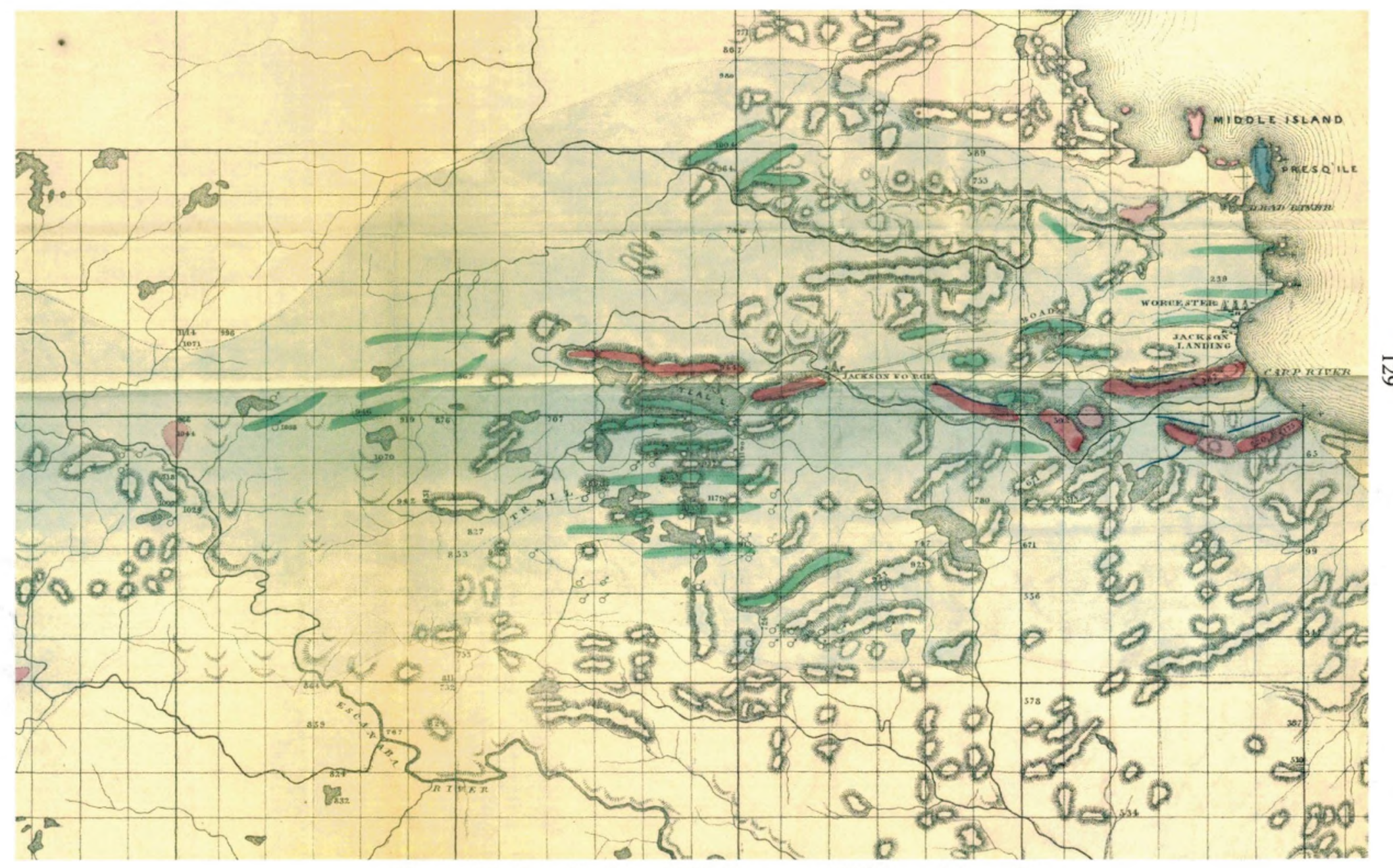

Figure 17. Detail of the 1851 Foster and Whitney Map of the

Natural and Cultural Features of the Marquette Range 
South of the Marquette Range Supergroup is a granite and gneiss complex dated at 2.5 billion years old. ${ }^{38}$

The Supergroup, an Early Proterozoic sequence of mostly sedimentary rocks that were deposited uncomformably on Archean greenstones and gneisses of the Superior Craton, is divided into four major groups, two of which contain formations relevant to the iron mining on the Range. ${ }^{39}$ The Menominee Group was deposited in a passive margin environment, the basal sandstone represented as the Ajibik Quartzite following metamorphosis. The unit deposited on top of this, the Siamo Slate consists of argillite and slate and forms an aquitard in the basin limiting the flow of groundwater. In some cases this unit was the footwall of the iron mines in the district, with the non-porous nature of the formation allowing for the formation of rich iron deposits directly above the slate at the bottom of the Negaunee Iron Formation. The unit greatly affected the distribution of rich ore throughout the Iron Formation. Figure 18, two generalized cross sections created by Burton Boyum, shows the role that the Siamo had in concentrating the soft ores of the Range. Above the Siamo is the Negaunee Iron Formation, intruded by metadiabase, and then the Goodrich Quartzite. ${ }^{40}$

The surface rock of the Negaunee/Ishpeming area of the Marquette Range is almost exclusively formed of iron bearing rocks. These iron bearing rocks, heavily intruded by younger diabase igneous rock later converted to metadiabase through applied heat and pressure, are also covered by a thin layer of drift deposits from glaciation and the erosion of the bedrock of the area. Interspersed with the metadiabase beneath the drift deposits is the very thick and spatially extensive Negaunee Iron Formation, 3,500 feet thick in some places, and consisting of extremely disturbed and deformed strata rich in iron, jasper, and quartz. ${ }^{41}$

The extreme age and complexity of the rocks of the Marquette Range inspired, yet also confused the initial prospectors and scientists to the area. The layered rocks were distorted and folded extensively in "plicated and corrugated," ${ }^{42}$ laminated, banded seams, outcropping in fantastic shapes that exposed banded formations containing layers of chert, interbedded with iron rich minerals. In 1873, T.B. Brooks evocatively described a portion of the Champion Mine as containing: "minor irregular lens' and pod-shaped 


\section{Geologic Cross Section of the Marquette Range}
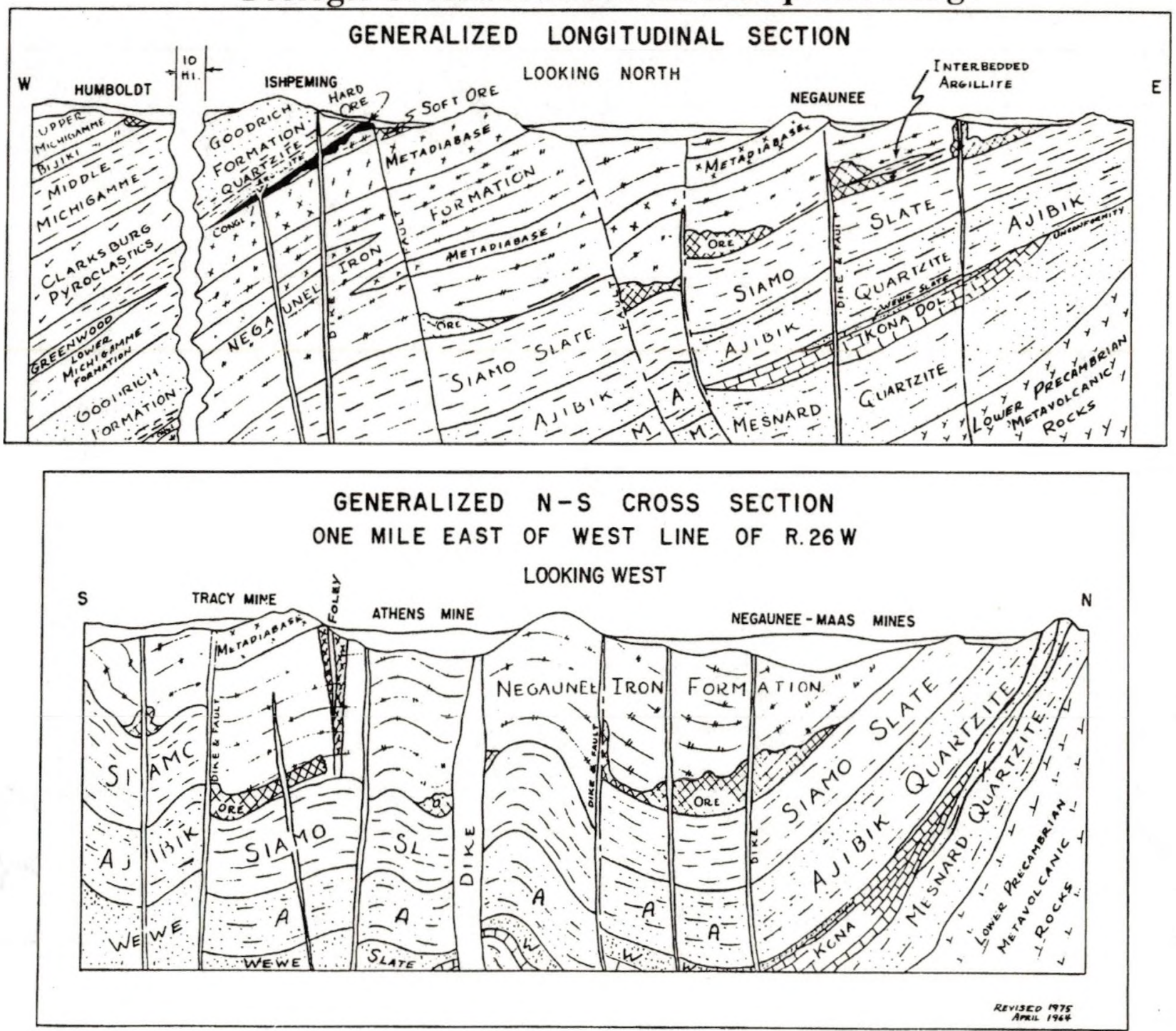

Figure 18. Geologic Cross-Sections of the Marquette Range 
masses of pure ore,...together with whitish and greenish magnesian schists alternat(ing) like the muscles of an animal." ${ }^{43}$ Describing the Cleveland location in 1851, shown as number 130 in Figure 16, Foster and Whitney described the extraordinary structure of the alternating bands of the rock as varying in thickness from a sheet of paper to $1 / 4$ of an inch. The beds were "twisted and contorted in every variety of form and outline; the curvatures are, however, mostly on a very small scale, the radius of curvature in the concentrically folded layers being never as great as one foot in length. The deep-red color of the jaspery portion contrasts admirably with the steel-gray of the less silicious bands; indeed, the singular beauty presented to the eye on stripping off the mossy covering of a vertical wall thus decorated by innumerable, fantastically-interwoven stripes of harmonizing and brilliant colors can hardly be exaggerated." ${ }^{, 4}$ The greatly disturbed strata, changed from their original structure and position, were mostly deformed plastically, bending in response to the applied pressure. However, rupture of the bedding did occur in response to pressures, with the ends of the bed coming into faulted position with each other. The fractured irregular and corrugated troughs often presented the upturned edges of their bedding, standing nearly vertically, outcropping at the surface. ${ }^{45}$ Recemented by silicious ground mass, the cracks of the shattered rock were often filled in by hydrated oxide of iron in various forms, creating rich deposits of iron. ${ }^{46}$

The massive size, and vast spatial extent of the beds of iron ore on the Range were surprising and inspirational to the first settlers and scientists to the area. Not all of the iron formation was pure enough to be mined, however in certain parts of the formation pure iron ore outcropped in large bodies. The Jackson and Cleveland locations were the most famous of these large outcrops, eliciting reverential admiration in those who wrote of them. Of one of these outcrops Foster wrote: "it was composed for the most part of nearly pure specular oxide of iron...It shoots up in a cliff 113 feet in height, so pure it is difficult to determine its mineralogical associations... Thus one cliff contains iron sufficient to supply the world for ages." ${ }^{47}$ When Lewis Henry Morgan first set his eyes upon the iron beds of the Range he wrote that it was impossible to describe the extent of the deposits. ${ }^{48}$ He described ledges of unknown width and depth but 
outcropping for nearly a mile, presenting the appearance, when uncovered like the Jackson location, of a cliff of almost pure iron, blue-black in color. ${ }^{49}$ The location, according to Morgan, contained millions of tons of the best iron in the world. He wrote effusively that "the deposit is possibly inexhaustible. Such a vast and unlimited deposit of ore, as is found here, staggers the belief of anyone who had not seen it."

In one of the first written descriptions of the Range, Bela Hubbard wrote in 1845 specifically of what would later become the Jackson and Cleveland locations:

These Rocks are throughout pervaded by the argillaceous red and micaceous oxides of iron, sometimes intimately disseminated, and sometimes in beds or veins. These are frequently of so great extent as almost to entitle them to be considered as rocks. The largest extent of iron ore noticed, is in town 47 north, range 26 west, near the corner of sections $29,30,31,32$. There are here two large beds or hills of ore, made up almost entirely of granulated, magnetic and specular iron, with small quantities of spathose and micaceous iron. The more northerly of these hills extends, in a direction nearly east and west, for at least one-fourth of a mile, and has a breadth little less than 1000 feet, the whole of which forms a single mass of ore, with occasional thin strata of imperfect chert and jasper, and dips north 10 degrees east, about 30 degrees. At its southerly outcrop the ore is exposed in a low cliff, above which the hill rises to the height of 20 to 30 feet above the country, on the south. The ore here exhibits a stratified or laminated structure, and breaks readily into sub-rhomboidal fragments, in such a manner as will greatly facilitate the operation of quarrying or mining the ore...This bed of iron will compare, favorably, both for extent and quality, with any known in our country. ${ }^{51}$

\section{The Effect of the Geologic Features on the Mining of the Marquette Range}

In the early stages of mining on the Range, surficial hard ore deposits were stripped from the land. Deposits not containing nor as rich in iron that covered the ore often had to be stripped from the surface before the mining could continue. As these near surface deposits were exhausted the mines began to extend into the earth, continuing the removal of both the ore and the country rock surrounding it. While the natural features played an important role in defining the settlement of the area, concurrent human processes began to greatly transform the natural distribution of the rocks that surrounded them. 
The Negaunee Iron Formation consists of carbonate, silicate and oxide iron formations. Where large amounts of water was present, common near the bottom of the formation, along faults and where igneous rocks intruded the ore, the iron formation became enriched. Although this process of secondary enrichment was very important to determining the location of the high grade ore within the larger matrix of the Neagunee Iron formation, it was not always a predictable relationship, and the rich ore was found in extremely variable locations and forms.

The ore mined throughout the $19^{\text {th }}$ century into the middle of the $20^{\text {th }}$ century was limited to the high grade direct shipping or natural iron ore deposits of the Range. The higher grade ores contained a relatively small position within the matrix of taconite ore, a much lower grade but more extensive iron ore in the Negaunee Iron Formation. This lower grade of ore was not mined until the middle of the $20^{\text {th }}$ century, and is what is currently being mined in the area today. The high grade ores are separated into hard and soft ores, with the distribution of the two ore types correlating with the grade of metamorphism of the host rocks. The hard ores dense, compact, low in porosity and colored blue, blue-black to reddish black, or steel gray to shiny were found in the higher grade metamorphosed rocks such as biotite, garnet, staurolite, and sillimanite. ${ }^{52}$ Because of the low porosity of this ore the moisture content is usually less than two percent. The soft ores, friable and earthy, are much less stable and cohesive, are dark red to reddish blue and even orange and yellow in color, are porous, and usually contain 10 percent moisture. ${ }^{53}$ This ore was found mostly in the chlorite metamorphic grade rocks. ${ }^{54}$ The soft ore was described as schistose and mixed because of its weakness and propensity to be banded with jasper. ${ }^{55}$

The hard ores, the richest and most uniform of the ores, were generally found at the top of the Negaunee Iron Formation in autonomous, distinct pockets. They were concentrated near old land surfaces and then folded in the geological upheaval of the region. The hard ores mined and then shipped from the Marquette Range totaled $60,350,944$ tons. ${ }^{56}$ The soft ores were found in two principle locations, at the base of the formation and above certain intrusive basaltic sills. The total ore mined and shipped from the former location, also known as the footwall soft ore totaled 186,607,540 tons; the 
latter sill soft ore mined and shipped totaled 54,092,030 tons. ${ }^{57}$ The soft ores were found in the vicinity of Ishpeming lying on top of the intrusive igneous rocks just below the hard-ore horizon, and in the lower 300 feet of the iron formation in a series of faulted segments or minor folds in the main basin from Negaunee to North Lake. The cross sections shown in Figure 18 show the distribution of these ores and the structural controls on some of the ore. The soft ore often constituted the hanging wall of the shaft mines, without possessing the requisite strength for a good roof. Large rock pillars or extensive timber supports had to be employed to make mining this ore possible. ${ }^{58}$

The structure of the iron ore within the Negaunee Iron Formation was also quite variable. The ore was found in separated pockets, not in veins. Narrow in one location, the ore widened into pockets larger than 50 feet in diameter in others. ${ }^{59}$ Deformed by applied pressure, the ore commonly wedged out and then began again in other places, forming lenticular or pod shaped deposits. Writing of this variability in 1865, Foster stated that although the iron beds were as thick as five hundred feet, with a width up to five thousand feet, "they are far from being persistent in character. The quartzose materials so abound that it is only in pockets, or lenticular bands, that the highly concentrated ores are found." ${ }^{, 60}$ The structure of local iron beds often changed suddenly in the direction and amount of their dip, causing constant revision of the plans for attacking the ore, as well as the planning of roof support in underground work. In some places the deposits were not in layered form, but rather the product of percolating water leaching out silicious matter and replacing it with iron in solution. The ore was deposited in localized places as irregular and varied as the path of the water seeping through the ground. $^{61}$

Because the nature of the ore changed considerably at each location, the rates and success of the mining technique at each location varied considerably. Each location was defined by the ore present. In 1881, Carl Rominger described the Jackson Mine as being "forced to take ore from different belts, of which nearly every one furnishes a different kind of ore, but the chaotically plicated and dislocated condition of the rock beds rarely allows recognition of the exact relative position which one belt holds to another; the miner pursuing a belt often finds it wedging out or abruptly cut off, and has to take his 
chances by drifting ahead in some direction to meet the other end again, or to find another different seem." A.P. Swineford also addressed the complexity of the rocks at the Jackson mine, stating in the early 1880's: "Geologically, the formation at the Jackson possesses great irregularity...the formation is exceedingly contorted and broken up, the veins doubling and folding in a manner nearly defying definite determination. The somewhat friable, disintegrating character of the rock has added an element of perplexity to the problem of how best to find and win the ore...the occurrence of the ore deposits is largely a matter of conjecture, and their continuance when formed is only determined by the working. Extensive explorations are constantly made in the mine by means of trial shafts, cross-cuts, and drifts made here and there, seemingly, to the novice, at random, but really located with the greatest care by Capt. Merry, whose twenty years' experience in charge of the mines and the company's interests have given him a degree of familiarity with all the difficulties to be encountered, and a knowledge of the peculiarities of the formation. ${ }^{, 62}$ All of the other mines on the Range faced similar problems.

As shown in Figure 18, above the Negaunee Iron Formation lies the lowest unit of the Baraga Group, the Goodrich Quartzite. This quartzite often acted as a solid and supportive headwall or roof of the mines as they went beneath the surface, but while the mines stayed open to the surface, the quartzite, very hard and resistant to blasting, had to be removed before excavation of the ore could occur. In some places up to 50 feet of Goodrich was removed to get at the iron beds from the surface workings.

Not all of the mines had to deal with removing the hard quartzite from their locations. Because of the variable nature of the stratigraphy of the Marquette Range, the Goodrich Quartzite was not always on top of the iron formation, with sometimes less resistant shales and slates overlying it instead. These softer, less resistant rocks were easier to remove where they acted as overburden for the iron, however as headwalls they were very poor and had to be extensively supported, causing difficulty with underground work.

The hydrogeology, which played such an important role in concentrating the iron and determining the distribution of mines on the Range, also hindered operations by intruding both surface and underground operations. Many of the mines intersected the 
water table in their pursuit of the iron, allowing water to seep into the pits and shafts, and mandating that the water be lifted out by pump. This was a large cost to several operations on the Range. The blasting of rock in the pursuit of new ore was also affected by water present at the location. Water in the interstices of the rock, even after the mines had been pumped or drained, made repeated charging and firing in the same drill holes nearly impossible; where it did occur the firing was less effective. ${ }^{63}$ The saturated rock was very dangerous to try to support in the underground mines. As groundwater forced adjustments within the mining on the Range, the pumping, particularly in the deeper shafts greatly affected the water table. Very large cones of depression were created as the water table was lowered at points centered on the mine shafts.

\section{The Open Pit, Surficial Workings}

Hard iron ore, found near the surface, was the first iron ore to be mined on the Marquette Range. The large outcropping bodies at the Jackson and Cleveland locations were examples of these large surface deposits that were quarried beginning in the 1840's and 1850 's by the initial mining ventures in the region. The process of extracting the ore was a simple one. The iron ore was cleared of any overburden and then explosives were placed in the ore to loosen and crack the material. The economy of blasting the surface ore with charges of powder made the open pit method practical even when the overburden was many yards thick. After the rock was blasted into smaller pieces, with some of the larger chunks in turn needing to be blasted again, the rock was crushed using hammers, shoveled into carts and transported to furnace or ship. ${ }^{64}$ In 1870 , the ore of the Marquette Range was still being extracted from rich near surface deposits and the open excavations spread in areally extensive workings, following the extent of the ore along the surface in a general east-west trend following the overall path of the ore bodies. ${ }^{65}$ The workings, with jagged, precipitous walls formed by blasting, were irregular, and contained many small excavations extending from the main pits. ${ }^{66}$ Sometimes ten or more large, elongated pits were more or less connected together following the strike of the ore. ${ }^{67}$ In addition to the numerous larger excavations, hundreds of test-pits riddled the surface. Near each of the mines, in the midst of working machinery, men and animals, 
large piles of waste rock grew with each blast. It was not uncommon for these piles to be moved several times in an attempt to keep the tailings out of the way of the work of the mine. ${ }^{68}$

Because the nature of the ore changed considerably at each location the rates and success of the technique could vary considerably, yet the technique remained consistent and it was common to use contractors at the mines who performed the same tasks at each of the locations they worked. In 1872, the Jackson, Cleveland, and Lake Superior mining operations, three of the largest on the Range at the time, employed 1002 men to perform ore excavation; out of this number, 740 were contractors. ${ }^{69}$ The initial step of the work these men performed at the mines involved the drilling, or rock-boring, all done by hand, of a hole two inches in diameter and up to 22 feet into the earth. The drill employed in this work was made of a steel rod 11/4 inches in diameter, varying in length up to 24 feet long with a two inch diameter drill bit. ${ }^{70}$ The drill was turned by one man sitting and struck by two men standing with eight pound hammers averaging 36 blows per minute each. ${ }^{71}$ At this rate, nine to eleven feet of hole could be sunk every day, however the amount of depth varied considerably with the hardness of the ore. Foster wrote of the process in 1851: "The superintendent of a mine informs me that he has known three men to work eleven hours to penetrate a foot in a jaspery ore; and again, in a red hematite, the same force has penetrated 14 feet in the same time.,"72

After drilling, a small charge of explosive was placed in the hole that when ignited created an initial blast meant only to produce cracks and jointing in the rocks near the bottom of the hole. This loosened up the rocks for the second more powerful charge, which consisted of as much as $20 \mathrm{kegs}$ of powder, 25 pounds each which when successful, lifted up to 5,000 tons of the earth in a terrifically powerful explosion. ${ }^{73}$ Powder and fuse was most commonly employed in the blasting, however, over time nitroglycerine was also used on the Range. The blasted ore was separated from country rock, if it was present, by employing 18 to 23 pound sledges. It was also necessary to crush the ore with the hammers into very fine pieces, which then allowed the ore to be further crushed by mechanical means and then processed. ${ }^{74}$ 
Most of the work performed in the mines during the early history of the Range was carried out by men and horses. By the 1870 's steam machinery had been constructed at most of the mines, allowing for the hoisting of ore out of the progressively deeper open pits, and for the pumping of intruding groundwater; many small locomotives carried the ore from the pits to the main railroad. ${ }^{75}$ However, even with this machinery, horses still played an important role in the process, performing about half of the handling of the ore and representing a substantial cost to the mining operation. T.B. Brooks estimated of the Range in 1870 that the 364 working horses, an average of 30 at each mine, accounted for 10 percent of the entire cost of the operation of the mines. ${ }^{76}$

The favorable position of the near surface iron deposits allowed for increasing efficiency in the removal of the ores and the beginning of their exhaustion. Large pits were dug throughout the area, progressively going deeper into the earth, the walls becoming less steady. In the early 1880's the Jackson mine had seven pits dug into their property, all of large size, with the South Jackson, one of these pits, extending a quarter of a mile in length, 60 feet in width, and over 100 feet in depth. ${ }^{77}$ At this same time the Cleveland Mine had dug a pit 160 feet deep, 400 feet long and 200 feet wide before they started to go underground. ${ }^{78}$ The Lake Superior Mine had two pits that exceeded 100 feet in depth, while the Cambria mine shown as number 126 in Figure 15 contained five pits, the most easterly of which was 100 feet square. ${ }^{79}$ The Chicago Mine (159) had dug a pit 80 feet deep to get at the ore, and the workings of the Lake Angeline mine (125) consisted of two connected open pits stretching 1000 feet in length. ${ }^{80}$

\section{Early Transportation Improvements on the Marquette Range}

The increase in efficiency of the mining technique, extracting the near surface deposits of the Range, was spurred on through transportation improvements which allowed more iron to be transported to markets. The improvements, which took many years to develop, allowed settlement on the Range to grow in proportion to the amount of natural resources there to be exploited by connecting the source of the extracted resources with the demand for those resources. The Civil War, greatly increasing the demand for iron, gave enormous impetus to iron production on the Marquette Range. From 1861 to 
1863 shipments of ore from the Marquette Range rose from 45,430 tons to 185,257 tons with the growth instigated by economic factors: the price of pig iron rose from $\$ 23$ per ton to $\$ 45$ per ton during that same period. ${ }^{81}$ Prior to 1863 , only the Jackson Iron Company, the Cleveland Iron Company, and the Lake Superior Iron Company had produced major amounts ore, however the growth associated with the rise in price led to the opening, in quick succession, of the New England, Parsons, Peninsular, Excelsior, and Collins mines. After 1863, due to increased war demand and the improvement of the transportation of the region, more new mines opened, so that by 1868 fifteen separate mining companies were extracting iron ore from the Marquette Range. By 1878 the number of working mines had jumped to 58 , with some of these locations lasting only a short time while others continued well into the $20^{\text {th }}$ century. ${ }^{82}$ This major increase in infrastructure and mining development on the Range was made possible by the transportation improvements in the area which grew slowly and in punctuated steps.

Each of the numerous mines needed a proximate work force and since during this period transportation was mostly by foot, each mine had with it an associated small community usually taking the same name as the mine. The names of the locations viewed spatially outline fairly accurately the outline of the Marquette Iron Range. Since the wide spread dissemination of the automobile the population has tended to concentrate in Marquette, Ishpeming and Negaunee, however in the $19^{\text {th }}$ century numerous small communites were separated from one another by the cutover forest, each more or less self-contained. The mines determined the locations of the settlements and the transportation routes connecting those settlements. ${ }^{83}$

Originally, travel between the Jackson location and the shores of Lake Superior in the early days of extraction and the beginning of settlement in the area was by an Indian trail, approximately following the flowing path of the Carp River. Upon the completion of the Carp River Forge a wagon road was constructed to the Jackson Mine, and a few years later the wagon road was continued to the beginnings of the settlement of Marquette. The road was rough, and travel on it was quite slow; in 1850, it is estimated that it took two six horse teams the better part of a day to draw three tons of iron to the mouth of the Carp River from the mines. ${ }^{84}$ With only a trickle of iron able to make it to a 
market, the early failures of the iron production on the Range to be economical were a result of these rudimentary levels of transportation. The initial settlers in the area and early government surveyors and geologists, recognizing this problem, called for the national government to open a road or a railroad in the area, however, the government was reluctant to reach out so far into the wilderness to lend its support so the original ventures to build adequate transportation to the mines were privately funded. A plank road was begun in 1853 from Marquette to the Jackson and Cleveland locations, and was financed jointly by these two companies to allow an increase in their mine production. The road was eventually altered to a tram railway, on which mules were used as locomotive power to haul ore on rails, and was completed in 1856 at a cost of $\$ 120,000$. $^{85}$ This tram railway ran for only a few years at an inefficient rate and was soon put out of business, in 1857, by the first railroad in the Upper Peninsula.

The Iron Mountain Railroad was constructed by a group of associates led by Heman B. Ely that arrived on the Marquette Range in 1851 from Rochester, New York. Ely and his associates were interested in building a railroad from the settlement of Marquette to the iron mines, and arrived with an influx of capital mostly accumulated through flour milling in Rochester. ${ }^{86}$ Prior to February of 1855 , no general railroad law existed in Michigan, so that the line begun by Ely in 1853 was strictly a private road. In its beginning stages, the railroad was not a competitive enterprise; its construction was amenable to all of the mining interests on the Range and was supported by those who would begin the tram railway in a few years. The success of the line, in an area just removed from the wilderness and quite isolated, seemed dependent upon cordial contractual relations between Ely's company and the Jackson and Cleveland companies. On November 7, 1851, Ely entered a contract with the Jackson Iron Co. to build a railroad the twelve miles from Iron Bay on Lake Superior to the Jackson location. The projected line was promised a monopoly of the trade of the mining company, and also aid from the company in building the line including right of way on company lands, a small parcel of land on the Jackson site and the right to take building materials such as lumber, sand and gravel from the Jackson lands. In exchange for these concessions, Ely promised not to engage in discriminatory rate practices, and agreed to a definite freight rate. On 
November, 11, 1851, a similar contract was signed with the Cleveland Iron Company and by July of 1852 the route of the line had been located. ${ }^{87}$ In the spring of 1853 as construction of the line began, Ely ran into a lack of capital. At this point Ely asked the Jackson and Cleveland companies for $\$ 50,000$ each in funds for the projected line. Concurrent to this action, in August of 1854, Ely and his associates formed the Lake Superior Iron Company and purchased 430 acres of land at the end of the proposed Railroad for the purpose of mining, smelting and manufacturing iron. Furious at the action of Ely both the Jackson and Cleveland companies attempted to back out of the contracts each had signed, concentrating instead on the construction of the tram railway to the mines. ${ }^{88}$

Despite these troubles, Ely, now alone in the venture to build the railroad, forged ahead and in 1852 secured the right of way for his line through public lands. The construction was a difficult one. Because of the rugged terrain of the Marquette Range, the construction of the railroad progressed slowly and both the Jackson and Cleveland companies challenged the right of way of the railroad through their lands in the courts. Estimates for the cost of the road rose from $\$ 2,000$ to $\$ 12,586$ per mile due mostly to the terrain. ${ }^{89}$ Through all of the adversity the line was finally completed to the Lake Superior Mine in 1857, and immediately took over the exclusive hauling of freight on the Marquette Range. Coinciding with the opening of the Soo Lock at Sault Ste. Marie, transportation on the Range now was able to take advantage of the massive deposits of the Range, and the increasing demand for iron throughout the country. By 1860 there were five trains that ran daily each way with each train hauling 20 to 25 ore cars and every other train hauling a passenger car. The 18 miles from Marquette to the Lake Superior Mine took the train about one hour and 45 minutes to travel; a great improvement over the day long wagon hauls a few years earlier. In 1858, 30,556 tons of ore was carried from the mines to Marquette and by 1860 that number had reached 150,903 tons. In $1858,1,627$ tons of pig iron was carried on the line, and by 1860 that number became 3,560 tons carried. ${ }^{90}$ 


\section{The Underground Workings}

With an increase in the ability of the ore to be transported, an ever increasing work force, an increase in the number of companies involved in the mining, more efficient techniques of removal and an increase in market demand, the surface hard ore deposits of iron began to be exhausted at an ever increasing rate. Exhaustion of the extensive deposits occurred slowly, and the hard ore at certain locations lasted much longer than at others. Slowly, hesitantly, beginning in the 1870's and 1880's, individual mines began pushing their open pits deeper into the earth, with some intruding into the grounds at angles, following the downward sloping and irregular formations, their workings just visible to the outside world.

The underground shafts were started when the overburden was too thick to be peeled off without excessive cost, or when the walls of the open excavations became too unstable and dangerous. In the beginning stages, the mines became an underground quarry or operation in a cave with the miners simply leaving the overburden and driving under the capping, following the ore. They built incline skiproads or tram railways back to the surface to hoist the ore out into the open to the cars and descended into the shafts on ladders. If there was danger of the roof caving in, they supported it by leaving pillars of ore under it, or by building sometimes elaborate supports from the hardwoods found on the Range. ${ }^{91}$

The location of the shafts and adits of the underground mines was simply a result of where the ore looked most promising, and the miners would follow the iron until it ran out or the workings became too dangerous. This haphazard system of mining, following the deposits under the surface without systematic planning and exploration providing foreknowledge of the location of the deposits, though possible in the surface operations, was not possible in the underground mining, and was abandoned quickly. The costs of underground mining were too great to haphazardly follow the deposits; a great deal of systematic planning was needed for such a mine to be economical and safe. ${ }^{92}$ Underground mining required elaborate machinery, a large use of timber for supports and highly skilled labor not easy to come by in an area only 15 years removed from the wilderness and still greatly isolated from the main population centers of the U.S. What 
was needed was a way of determining what lied beneath the surface before the shafts were dug, and this came about in the 1870's with the beginning of the widespread use of the diamond bit drill. ${ }^{93}$ The drill allowed the iron deposits deep beneath the surface to be located with precision and allowed for the more systematic planning and execution of underground work in the mines. The costs of drilling and constructing the shafts beneath the earth were prohibitively expensive and many mining companies who found success with the surficial iron deposits did not have the necessary capital to begin underground mining. In the highly deformed and sometimes weak rock of the Range only detailed planning and execution could succeed in a safe and economical way. These factors led to capital consolidation on the Range with a few major corporations dominating what had been a very abundant and diverse industry. ${ }^{94}$

At very nearly every mine on the Range both surface work and underground work occurred at the same location. The transition between the two types of mining was gradational, the surface work leading to underground work out of necessity determined by the natural distribution of the ore. The relationship led to a complex distribution of shafts and pits intermixed and connecting with each other in the mines. Figure 19, a layout of the Lake Superior Mine by T.B. Brooks in 1870, shows an example of this complex intermixing caused by the nature of both the ore and the country rock of the Range. Commencing operations in the summer of 1857, the Lake Superior Mine grew to be one of the largest and most successful of the mining operations on the Range in the 19th century. During one year in the early 1880's the mine withdrew more ore than any other mine in the history of America ever had, and employed 500 men in a complex and extensive operation. ${ }^{95}$ Swineford, describing the mine in 1881, stated: "The workings of this company are on a very extensive scale. Their numerous pits and shafts leading to immense underground caverns made in stoping out the ore, the miles of levels and drifts from which the king of metals has been removed, and the many lenses of fine ore upon which the large body of miners is actively engaged at work, and these large pits illuminated by brilliant electric lights forms a picture at once grand weird and entrancing, and unfolds some of the possibilities of human intellect, and of the grand results of labor backed by capital and enterprise." 96 Eventually, the Lake Superior Mine would be 


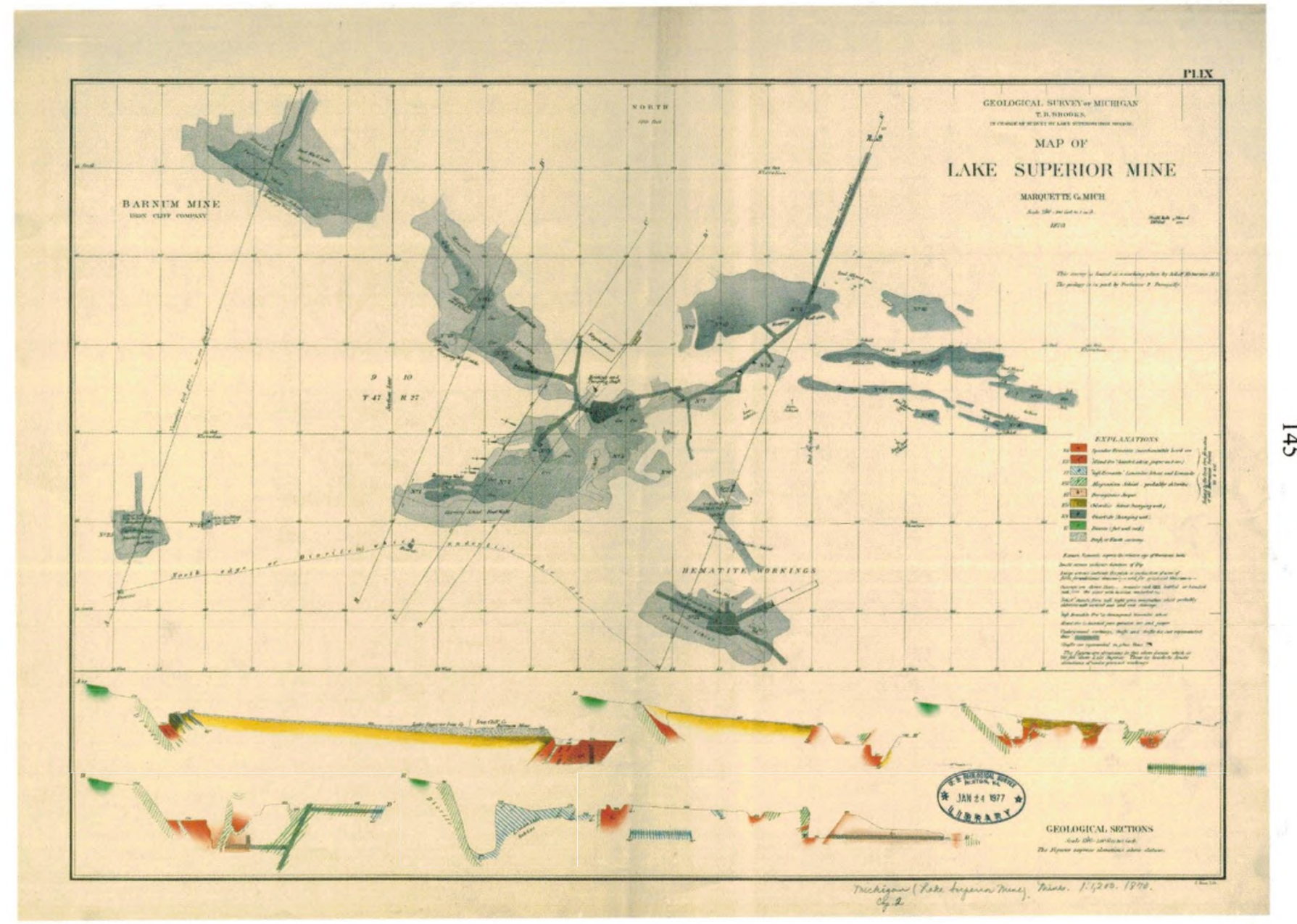

Figure 19. The Distibution of Open Pit and Underground Workings at the Lake Superior Mine, 1870 
strictly an underground operation, but from Figure 19 we see that as the pits became too deep to work safely, shafts extending away from the pits were dug. Some of the shafts connected with other pits or hubs where lifts brought the ore to the surface. Shown in the darker color in the figure, the shafts expanded into large chambers or galleries that were supported by pillars and timber. By 1880, two large chambers, both 20 feet in height, with one 95 by 120 feet large and the other 50 by 115 feet large, had been dug beneath the surface of the Lake Superior property. ${ }^{97}$ The shafts of the Lake Superior mine at this time descended nearly 300 feet beneath the surface, and the Barnum mine just to the northeast went even further, down to 400 feet. $^{98}$

Descending the ladders into the labyrinth of tunnels and drifts of the underground workings, the miners found themselves in a dark and wet world. Of a trip into the underground workings of the Lake Superior mine in the late 1860's A.P. Swineford wrote: "Encased in a miners suit and equipped with a tallow dip, we descended the main shaft with Captain Johnson as our guide. Down the ladder we go into utter darkness, save and except the faint light from our tallow dips-down, down, till was begin to think we are attempting to fathom the depths of the bottomless pit." 99 The mines of the Marquette Range would continue to mine ore from beneath the surface throughout the rest of the $19^{\text {th }}$ and into the $20^{\text {th }}$ century. Because fewer mines operated beneath the ground, the numerous settlements on the Range converged into a smaller number, as the scores of independent mines became four or five large companies. Major shaft mines at Negaunee, Ishpeming, Palmer, and Republic, in association with improvements in transportation began to concentrate this population.

\section{Conclusion}

Different societies choose different ways of interacting with the natural environment that surrounds them. ${ }^{100}$ These choices, set within the context of geology and ecology, modify the human institutions of economy, class, and politics. The choices also affect, in turn, the natural systems, redefining the natural progression of change by accelerating the rates of change and by shifting focus toward extracting resources valuable within a market system. The society of the Marquette Range, beginning with 
the first European travelers to the area, chose to extract the resources of the Range for the profit of society. The iron present in very large beds conditioned the settlement of the Marquette Range and had profound effects on the structure and success of that society.

In order to understand the progression of society on the Range one must understand the nature of the geology of the Range; the geology that determined the method of the mining employed, and therefore the lives of the people who came to the Range. Within the Negaunee Iron Formation each mining locality differed from the other in the character of its rocks. ${ }^{101}$ The success or failure of individual mining interests on the Range was often controlled by these natural features. The nature of the ore, both the hard and soft ores, contributed greatly to the approach of the mining companies on the Range with the spatial distribution of the iron formation, both surficially and with depth, determining the spatial distribution of the digging.

Tied closely to iron mining, the transportation of the $19^{\text {th }}$ century Marquette Range was created by, and allowed for the success of the iron mines. The natural features that changed so much from the days of Douglass Houghton to the end of the 1800 's changed because they were attached to a market, where their value could be tied directly to capital. The transportation on the Range connected the market and the resource, and the vast amounts of naturally provided plentitude merged with a hungry and growing nation.

No single other factor played more of a part in the history of the Marquette Range in the $19^{\text {th }}$ century than did iron ore. Its influence resonated through every aspect of a society that was a single resource town. The associated logging, which also played a very important part in determining the history of the Range, was very closely tied to the extraction and processing of the ore. In 1873, the mining industry on the Marquette Range employed over 3000 men, with the furnaces employing over 1000. At each mining and furnace location, settlements associated with the operations responded in a body to the mines' varying fortune. In the beginning of the $20^{\text {th }}$ century $86 \%$ of the workforce on the Range was associated with the mining industry. ${ }^{102}$ In an area so heavily influenced by one industry, the success of that industry had enormous effects on the distribution and size of the society. The natural features of the Range defined the mode 
of production on the Range, however, conversely, as human systems became more adept in these modes of production they became the most important modifiers of the natural systems. What existed in the late $19^{\text {th }}$ century on the Marquette Range was a great modification of what was there in the early $19^{\text {th }}$ century, and this was a result of man and of money. 
149

Table 1. MRDS Records of Mines on the Marquette Range

\begin{tabular}{|c|c|c|c|c|c|c|c|c|c|}
\hline Im & Site_name & $\begin{array}{l}\text { Mrds } \\
\text { record\# }\end{array}$ & Latitude & Longitude & Location_comments & $\begin{array}{l}\text { Yr_1st_ } \\
\text { produce } \\
\text { d }\end{array}$ & \begin{tabular}{|l|l|} 
Yr_last_- \\
produce \\
d
\end{tabular} & $\begin{array}{l}\text { Total prod- } \\
\text { uction (LT) }\end{array}$ & Workings_type \\
\hline 50 & RICHARDS MINE & W028626 & $46-04-24 \mathrm{~N}$ & $088-22-26 \mathrm{~W}$ & $\begin{array}{l}\text { POINT LOCATED WEST OF THE } \\
\text { CENTER OF THE RICHARDS } \\
\text { PROPERTY ON RIVERTON IRON } \\
\text { FORMATION. }\end{array}$ & 1913 & 1927 & 534448 & UNDERGROUND \\
\hline 101 & JACKSON MINE & & $46-30-00 \mathrm{~N}$ & $087-37-12 W$ & $\begin{array}{l}\text { POINT LOCATED AT THE CENTER OF } \\
\text { THE PROPERTY AT THE CENTER OF } \\
\text { SECTION } 1 \text { T } 47 \text { N R } 27 \mathrm{~W}\end{array}$ & 1848 & 1924 & 4357256 & $\begin{array}{l}\text { BOTH SURFACE } \\
\text { AND } \\
\text { UNDERGROUND }\end{array}$ \\
\hline 102 & MAGNETIC MINE & W028530 & $46-27-23 \mathrm{~N}$ & 088-05-44W & $\begin{array}{l}\text { POINT LOCATED IN THE } \\
\text { SOUTHWEST PART OF THE } \\
\text { PROPERTY ON THE NEGAUNEE IRON } \\
\text { FORMATION. }\end{array}$ & 1906 & 1906 & 292 & SURFACE \\
\hline 103 & ERIE MINE & W028532 & $46-26-51 \mathrm{~N}$ & 088-03-56W & $\begin{array}{l}\text { POINT LOCATED AT THE CENTER OF } \\
\text { THE PROPERTY. }\end{array}$ & 1876 & 1883 & 9194 & UNDERGROUND \\
\hline 104 & RIVERSIDE MINE & W028529 & $46-26-03 \mathrm{~N}$ & 088-01-29W & $\begin{array}{l}\text { POINT LOCATED ON THE } \\
\text { NORTHEAST PART OF THE } \\
\text { PROPERTY ON THE NEGAUNEE IRON } \\
\text { FORMATION. }\end{array}$ & 1888 & 1893 & 16160 & UNDERGROUND \\
\hline 105 & PHOENIX MINE & W062119 & $46-31-30 \mathrm{~N}$ & $087-57-54 \mathrm{~W}$ & $\begin{array}{l}\text { POINT LOCATED ON THE SOUTHERN } \\
\text { PART OF THE PROPERTY ON THE } \\
\text { BIIKI IRON FORMATION. }\end{array}$ & 1881 & 1887 & 59114 & SURFACE \\
\hline 106 & HORTENSE MINE & W062093 & $46-31-58 \mathrm{~N}$ & 087-56-49W & $\begin{array}{l}\text { POINT LOCATED AT THE CENTER OF } \\
\text { THE PROPERTY WHICH IS ADJACENT } \\
\text { TO PASCOE PROPERTY. }\end{array}$ & 1887 & 1890 & 30574 & UNDERGROUND \\
\hline 107 & GIBSON PROSPECT & W062089 & $46-31-29 \mathrm{~N}$ & 087-57-14W & $\begin{array}{l}\text { POINT LOCATED ON THE } \\
\text { NORTHWEST PART OF THE } \\
\text { PROPERTY ON THE BIJIKI IRON } \\
\text { FORMATION. }\end{array}$ & 1885 & 1887 & 16357 & SURFACE \\
\hline 108 & FOXDALE RESERVE & W062086 & $46-29-44 \mathrm{~N}$ & 087-54-30W & $\begin{array}{l}\text { POINT LOCATED AT THE CENTER OF } \\
\text { THE PROPERTY. }\end{array}$ & 1901 & 1905 & 31447 & UNDERGROUND \\
\hline 109 & SAMPSON MINE & W062131 & $46-29-34 \mathrm{~N}$ & $087-53-49 \mathrm{~W}$ & $\begin{array}{l}\text { POINT LOCATED ON THE SOUTHERN } \\
\text { PART OF THE PROPERTY ON THE } \\
\text { NEGAUNEE IRON FORMATION. } \\
\text { PART OF THE HUMBOLDT } \\
\text { LOCATION. }\end{array}$ & 1866 & 1892 & 267805 & SURFACE \\
\hline 110 & WASHINGTON MINE & W062137 & $46-29-26 \mathrm{~N}$ & 087-53-51W & $\begin{array}{l}\text { POINT LOCATED AT THE CENTER OF } \\
\text { THE PROPERTY. PART OF THE } \\
\text { HUMBOLDT LOCATION. }\end{array}$ & 1865 & 1920 & 1100741 & UNDERGROUND \\
\hline 111 & BLUEBERRY MINE & W062067 & $46-30-19 \mathrm{~N}$ & $087-48-32 W$ & $\begin{array}{l}\text { POINT LOCATED AT THE CENTER OF } \\
\text { THE PROPERTY. }\end{array}$ & 1929 & 1955 & 6077871 & UNDERGROUND \\
\hline 112 & BARNES-HECKER MINE & W062065 & $46-30-07 \mathrm{~N}$ & $087-46-26 \mathrm{~W}$ & $\begin{array}{l}\text { POINT LOCATED AT THE CENTER OF } \\
\text { THE PROPERTY. }\end{array}$ & 1923 & 1927 & 419433 & UNDERGROUND \\
\hline 113 & MORRIS MINE & W062112 & $46-29-55 \mathrm{~N}$ & 087-45-09W & $\begin{array}{l}\text { POINT LOCATED AT THE CENTER OF } \\
\text { THE PROPERTY. }\end{array}$ & 1912 & 1961 & 11013916 & UNDERGROUND \\
\hline 114 & LLOYD MINE & W062100 & $46-29-56 \mathrm{~N}$ & 087-43-50W & $\begin{array}{l}\text { POINT LOCATED AT THE CENTER OF } \\
\text { THE PROPERTY. }\end{array}$ & 1911 & 1957 & 9650958 & UNDERGROUND \\
\hline 115 & EXCELSIOR PROSPECT & W062082 & $46-29-47 \mathrm{~N}$ & $087-43-15 \mathrm{~W}$ & $\begin{array}{l}\text { POINT LOCATED ON THE } \\
\text { NOERHTERN PART OF THE } \\
\text { PROPERTY ON THE NEGAUNEE IRON } \\
\text { FORMATION. }\end{array}$ & 1872 & 1879 & 17939 & SURFACE \\
\hline 116 & GREENWOOD MINE & W062091 & $46-27-38 \mathrm{~N}$ & $087-46-05 \mathrm{~W}$ & $\begin{array}{l}\text { POINT LOCATED ON THE SOUTHERN } \\
\text { PART OF THE PROPERTY ON THE } \\
\text { NEGAUNEE IRON FORMATION. }\end{array}$ & 1932 & 1963 & 2365816 & UNDERGROUND \\
\hline 117 & FITCH PROSPECT & W062083 & $46-27-29 \mathrm{~N}$ & $087-44-33 W$ & $\begin{array}{l}\text { POINT LOCATED AT THE CENTER OF } \\
\text { THE PROPERTY. }\end{array}$ & 1890 & 1892 & 40263 & UNDERGROUND \\
\hline 118 & ALBION MINE & W062059 & $46-27-39 \mathrm{~N}$ & $087-43-54 \mathrm{~W}$ & $\begin{array}{l}\text { POINT LOCATED ON THE SOUTHERN } \\
\text { PART OF THE PROPERTY ON THE } \\
\text { NEGAUNEE IRON FORMATION. }\end{array}$ & 1872 & 1879 & 4592 & SURFACE \\
\hline 119 & SAGINAW MINE & W062129 & $46-27-28 \mathrm{~N}$ & $087-43-38 W$ & $\begin{array}{l}\text { POINT LOCATED AT THE CENTER OF } \\
\text { THE PROPERTY. }\end{array}$ & 1872 & 1891 & 451424 & UNDERGROUND \\
\hline 120 & NEW ENGLAND MINE & W062115 & $46-27-36 \mathrm{~N}$ & $087-42-57 W$ & $\begin{array}{l}\text { POINT LOCATED ON THE SOUTHERN } \\
\text { PART OF THE PROPERTY ON THE } \\
\text { NEGAUNEE IRON FORMATION. }\end{array}$ & 1866 & 1873 & 110506 & SURFACE \\
\hline 121 & MILLER PROPSECT & W062107 & $46-27-44 \mathrm{~N}$ & $087-41-14 \mathrm{~W}$ & $\begin{array}{l}\text { POINT LOCATED ON THE FAR } \\
\text { EASTERN PART OF THE PROPERTY } \\
\text { ON THE NEGAUNEE IRON } \\
\text { FORMATION. }\end{array}$ & N/A & N/A & 4756 & SURFACE \\
\hline 122 & FOSTER MINE & W062085 & $46-27-04 \mathrm{~N}$ & 087-39-03W & $\begin{array}{l}\text { POINT LOCATED AT THE CENTER OF } \\
\text { THE PROPERTY. }\end{array}$ & 1868 & 1903 & 351713 & UNDERGROUND \\
\hline 123 & TILDEN MINE & W001397 & $46-26-51 \mathrm{~N}$ & 087-38-17W & $\begin{array}{l}\text { POINT LOCATED AT THE CENTER OF } \\
\text { MAIN PIT. }\end{array}$ & 1929 & $\begin{array}{l}\text { ACTIV } \\
\mathrm{E}\end{array}$ & 126000000 & $\begin{array}{l}\text { BOTH SURFACE } \\
\text { AND } \\
\text { UNDERGROUND }\end{array}$ \\
\hline 124 & NATIONAL MINE & W062113 & $46-28-01 \mathrm{~N}$ & 087-40-49W & $\begin{array}{l}\text { POINT LOCATED AT THE CENTER OF } \\
\text { THE PROPERTY. }\end{array}$ & 1878 & 1884 & 155884 & UNDERGROUND \\
\hline 125 & LAKE ANGELINE MINE & W062097 & $46-28-39 \mathrm{~N}$ & 087-39-55W & $\begin{array}{l}\text { POINT LOCATED ON THE NORTHERN } \\
\text { PART OF THE PROPERTY ON THE } \\
\text { NEGAUNEE IRON FORMATION. }\end{array}$ & 1864 & 1922 & 9319679 & $\begin{array}{l}\text { BOTH SURFACE } \\
\text { AND } \\
\text { UNDERGROUND }\end{array}$ \\
\hline
\end{tabular}


150

Table 1. (continued)

\begin{tabular}{|c|c|c|c|c|c|c|c|c|c|}
\hline 126 & LAKE SUPERIOR GROUP & W062099 & $46-28-51 \mathrm{~N}$ & $087-40-38 \mathrm{~W}$ & $\begin{array}{l}\text { POINT LOCATED AT THE CENTER OF } \\
\text { THE PROPERTY. }\end{array}$ & 1858 & 1937 & 25103189 & UNDERGROUND \\
\hline 127 & NEW YORK & & $46-29-34 \mathrm{~N}$ & $087-39-32 W$ & $\begin{array}{l}\text { POINT LOCATED ON THE } \\
\text { SOUTHWEST PART OF THE } \\
\text { PROPERTY ON THE NEGAUNEE IRON } \\
\text { FORMATION. FORMELY KNOWN AS } \\
\text { THE YORK MINE. }\end{array}$ & 1864 & 1919 & 1124182 & \\
\hline 128 & CLEVELAND LAKE MINE & W062076 & $46-28-51 \mathrm{~N}$ & 087-39-43W & $\begin{array}{l}\text { POINT LOCATED WEST OF THE } \\
\text { CENTER OF THE PROPERTY ON THE } \\
\text { NEGAUNEE IRON FORMATION }\end{array}$ & 1854 & 1927 & 16315316 & UNDERGROUND \\
\hline 129 & MORO MINE & W062111 & $46-29-15 \mathrm{~N}$ & $087-39-27 \mathrm{~W}$ & $\begin{array}{l}\text { POINT LOCATED AT THE CENTER OF } \\
\text { THE PROPERTY. }\end{array}$ & 1890 & 1918 & 1119854 & UNDERGROUND \\
\hline 130 & CLEVELAND MINE & W062075 & $46-29-27 \mathrm{~N}$ & $087-39-12 \mathrm{~W}$ & $\begin{array}{l}\text { POINT LOCATED AT THE CENTER OF } \\
\text { THE PROPERTY. }\end{array}$ & 1849 & 1898 & (19.8 & UNDERGROUND \\
\hline 131 & MARQUETTE PROSPECT & W062104 & $46-28-35 \mathrm{~N}$ & $087-38-12 \mathrm{~W}$ & $\begin{array}{l}\text { POINT LOCATED ON THE EASTERN } \\
\text { SIDE OF THE PROPERTY ON THE } \\
\text { NEGAUNEE IRON FORMATION. }\end{array}$ & 1860 & 1892 & 268071 & SURFACE \\
\hline 132 & EMPIRE MINE & W001394 & $46-27-22 \mathrm{~N}$ & 087-36-20W & $\begin{array}{l}\text { POINT LOCATED AT THE CENTER OF } \\
\text { THE MAIN PIT. }\end{array}$ & 1907 & $\begin{array}{l}\text { ACTIV } \\
\text { E }\end{array}$ & 200000000 & SURFACE \\
\hline 133 & VOLUNTEER (OLD) MINE & W062136 & $46-26-09 \mathrm{~N}$ & $087-35-46 \mathrm{~W}$ & $\begin{array}{l}\text { POINT LOCATED ON THE } \\
\text { SOUTHEAST PART OF THE } \\
\text { PROPERTY ON THE NEGAUNEE IRON } \\
\text { FORMATION. ALSO INCLUDES THE } \\
\text { PALMER LOCATION. }\end{array}$ & 1871 & 1916 & 1705971 & UNDERGROUND \\
\hline 134 & ISABELLA MINE & W062095 & $46-26-04 \mathrm{~N}$ & $087-35-21 W$ & $\begin{array}{l}\text { POINT LOCATED AT THE CENTER OF } \\
\text { THE PROPERTY. }\end{array}$ & 1916 & 1934 & 1965929 & $\begin{array}{l}\text { BOTH SURFACE } \\
\text { AND } \\
\text { UNDERGROUND }\end{array}$ \\
\hline 135 & STAR WEST & & $46-26-16 \mathrm{~N}$ & $087-34-40 \mathrm{~W}$ & $\begin{array}{l}\text { POINT LOCATED AT THE CENTER OF } \\
\text { THE PROPERTY. FORMARLY } \\
\text { KNOWN AS HOME WHEAT AND } \\
\text { PROUT MINES. }\end{array}$ & 1873 & 1911 & 209115 & 5 UNDERGROUND \\
\hline 136 & PRIMROSE & & $46-26-09 \mathrm{~N}$ & 087-34-09w & $\begin{array}{l}\text { POINT LOCATED AT THE CENTER OF } \\
\text { THE PROPERTY. ALSO KNOWN AS } \\
\text { THE PRIMROSE VALLEY AND THE } \\
\text { JOYCE MINE. }\end{array}$ & 1896 & 1896 & 6040 & \\
\hline 137 & RICHMOND (OLD) MINE & W062126 & $46-26-18 \mathrm{~N}$ & 087-34-09W & $\begin{array}{l}\text { POINT LOCATED AT THE CENTER OF } \\
\text { THE PROPERTY. }\end{array}$ & 1896 & 1926 & 3604913 & 3 SURFACE \\
\hline 138 & CARR MINE & W062071 & $46-25-59 \mathrm{~N}$ & 087-34-13W & $\begin{array}{l}\text { POINT LOCATED ON THE } \\
\text { NORTHWEST PART OF THE } \\
\text { PROPERTY ON THE NEGAUNEE IRON } \\
\text { FORMATION. }\end{array}$ & 1873 & 1874 & 2380 & UNDERGROUND \\
\hline 140 & DETROIT MINE & W062080 & $46-30-03 \mathrm{~N}$ & 087-39-11W & $\begin{array}{l}\text { POINT LOCATED SOUTH OF THE } \\
\text { CENTER OF THE PROPERTY ON THE } \\
\text { NEGAUNEE IRON FORMATION. }\end{array}$ & 1882 & 1890 & 140841 & UNDERGROUND \\
\hline 141 & FOREST CITY PROSPECT & W062084 & $46-30-30 \mathrm{~N}$ & $087-38-51 W$ & $\begin{array}{l}\text { POINT LOCATED ON THE SOUTHERN } \\
\text { PART OF THE PROPERTY ON THE } \\
\text { NEGAUNEE IRON FORMATION. }\end{array}$ & & & I. & SURFACE \\
\hline 142 & CAMBRIA-JACKSON & W062070 & $46-30-32 \mathrm{~N}$ & 087-38-06W & $\begin{array}{l}\text { POINT LOCATED AT THE CENTER OF } \\
\text { THE CAMBRIA-JACKSON PROPERTY. } \\
\text { INCLUDED THE CAMBRIA. } \\
\text { HARTFORD AND LILLIE LOCATIONS. }\end{array}$ & 1874 & 1959 & 16165154 & UNDERGROUND \\
\hline 143 & MATHER MINE & W001392 & $46-29-55 \mathrm{~N}$ & $087-37-58 \mathrm{~W}$ & $\begin{array}{l}\text { POINT LOCATED AT THE CENTER OF } \\
\text { THE PROPERTY INCLUDING NEARLY } \\
\text { THE ENTIRETY OF SECTIONS } 1 \text { AND } \\
2 \text { T47N R27W. LCOATION INCLUDES } \\
\text { FORMER MINES: CLEVELAND } \\
\text { HEMATITE. EAST NEW YORK (1888- } \\
\text { 1905). IRON CENTRE. AMES (1893-94), } \\
\text { PRODUCTION NUMBER A } \\
\text { COMBINATION OF THES }\end{array}$ & 1888 & 1979 & 59089646 & 6 UNDERGROUND \\
\hline 144 & SECTION 12 MINE & W062132 & $46-29-28 \mathrm{~N}$ & 087-36-55W & $\begin{array}{l}\text { POINT LOCATED AT THE CENTER OF } \\
\text { THE PROPERTY. }\end{array}$ & 1879 & 1882 & 21887 & 7 SURFACE \\
\hline 145 & PONTIAC PROSPECT & W062122 & $46-29-25 \mathrm{~N}$ & $087-37-18 \mathrm{~W}$ & $\begin{array}{l}\text { POINT LOCATED ON THE } \\
\text { SOUTHEAST PART OF THE } \\
\text { PROPERTY ON THE NEGAUNEE IRON } \\
\text { FORMATION. }\end{array}$ & N/A & N/A & 1500 & SURFACE \\
\hline 147 & ADAMS MINE & W062058 & $46-30-16 \mathrm{~N}$ & $087-35-44 W$ & $\begin{array}{l}\text { POINT LOCATED AT THE CENTER OF } \\
\text { THE ADAMS PROPERTY. }\end{array}$ & 1913 & 1924 & 242348 & 8 UNDERGROUND \\
\hline 148 & NEGAUNEE MINE & W062114 & $46-30-02 \mathrm{~N}$ & $087-35-19 W$ & $\begin{array}{l}\text { POINT LOCATED AT THE CENTER OF } \\
\text { THE PROPERTY. }\end{array}$ & 1887 & 1949 & 22735479 & 9 UNDERGROUND \\
\hline 149 & BARASA PROSPECT & W062064 & $46-30-23 \mathrm{~N}$ & $087-34-49 \mathrm{~W}$ & $\begin{array}{l}\text { POINT LOCATED AT THE CENTER OF } \\
\text { THE PROPERTY. }\end{array}$ & 1903 & 1903 & 8768 & 8 UNDERGROUND \\
\hline 150 & PENDILL & & $46-29-53 \mathrm{~N}$ & 087-36-40W & $\begin{array}{l}\text { POINT LOCATED AT THE CENTER OF } \\
\text { THE PROPERTY. ALSO KNOWN AS } \\
\text { THE EAST JACKSON MINE AND WAS } \\
\text { ONCE A PART OF THE LUCY } \\
\text { PROPERTY. }\end{array}$ & 1878 & 1884 & 45993 & \\
\hline
\end{tabular}


Table 1. (continued)

\begin{tabular}{|c|c|c|c|c|c|c|c|c|c|}
\hline 151 & BREITUNG-HEMATITE & W062068 & $46-29-35 \mathrm{~N}$ & $087-35-46 \mathrm{~W}$ & $\begin{array}{l}\text { POINT LOCATED AT THE CENTER OF } \\
\text { THE PROPERTY. INCLUDES NEW } \\
\text { YORK HEMATITE AND BOTH ARE } \\
\text { PART OF THE TRACY GROUP. }\end{array}$ & \begin{tabular}{|l|} 
SEE \\
TRAC \\
Y \\
GROU \\
\end{tabular} & $\begin{array}{l}\text { SEE } \\
\text { TRACY } \\
\text { GROUP }\end{array}$ & 0 & UNDERGROUND \\
\hline 152 & 2 TRACY GROUP & W001393 & $46-29-25 \mathrm{~N}$ & 087-35-33W & $\begin{array}{l}\text { POINT LOCATED AT THE CENTER OF } \\
\text { THE TRACY GROUP PROPRTY } \\
\text { PROPERTY. PRODUCTION NUMBERS } \\
\text { INCLUDE MANGANESE. BRIETUNG- } \\
\text { HEMATITE. AND LUCKY STAR } \\
\text { LOCATIONS. }\end{array}$ & 1870 & 1971 & 9700926 & UNDERGROUND \\
\hline 153 & 3 LUCY MINE & W062102 & $46-29-32 \mathrm{~N}$ & $087-36-45 \mathrm{~W}$ & $\begin{array}{l}\text { POINT LOCATED WEST OF CENTER } \\
\text { OF THE PROPERTY ON NEGAUNEE } \\
\text { IRON FORMATION. }\end{array}$ & 1870 & 1913 & 622797 & UNDERGROUND \\
\hline 154 & 4 MANGANESE & & $46-29-28 \mathrm{~N}$ & $087-36-16 \mathrm{~W}$ & $\begin{array}{l}\text { POINT LOCATED AT THE CENTER OF } \\
\text { THE PROPERTY. INCLUDES THE } \\
\text { AETNA MINE WHICH WAS ALSO } \\
\text { REFERRED TO AS THE SCHADT } \\
\text { MINE. }\end{array}$ & 1883 & 1895 & 8711 & UNDERGROUND \\
\hline 155 & 5 REGENT GROUP & & $46-29-39 \mathrm{~N}$ & 087-35-09W & $\begin{array}{l}\text { POINT LOCATED AT THE CENTER OF } \\
\text { THE PROPERTY. FORMERLY PART } \\
\text { OF THE QUEEN GROUP WHICH } \\
\text { INCLUDED SOUTH BUFALOE MINE } \\
\text { ALSO KNOWN AS ANDERSON, } \\
\text { PRINCE OF W ALES ALSO KNOWN AS } \\
\text { THE GEORGE MITCHELL, AND } \\
\text { QUEEN ALSO KNOWN AS SWAN. }\end{array}$ & 1886 & 1917 & 8195123 & UNDERGROUND \\
\hline 157 & 7 ROWLAND PROSPECT & W062128 & $46-28-11 \mathrm{~N}$ & 087-35-33W & $\begin{array}{l}\text { POINT LOCATED ON THE WESTERN } \\
\text { PART OF THE PROPERTY ON THE } \\
\text { NEGAUNEE IRON FORMATION. }\end{array}$ & N/A & N/A & 2988 & \\
\hline 158 & HIMROD PROPSECT & W062092 & $46-28-59 \mathrm{~N}$ & $087-36-02 \mathrm{~W}$ & $\begin{array}{l}\text { POINT LOCATED AT THE CENTER OF } \\
\text { THE PROPERTY. }\end{array}$ & 1873 & 1873 & 2065 & UNDERGROUND \\
\hline 159 & CHICAGO PROSPECT & W062074 & $46-28-47 \mathrm{~N}$ & 087-36-00W & $\begin{array}{l}\text { POINT LOCATED AT THE CENTER OF } \\
\text { THE PROPERTY. }\end{array}$ & 1879 & 1883 & 9012 & UNDERGROUND \\
\hline 173 & 3 NORTH REPUBLIC & W028528 & $46-24-48 \mathrm{~N}$ & 088-00-51W & $\begin{array}{l}\text { POINT LOCATED AT THE CENTER OF } \\
\text { THE PROPERTY SE OF NE OF } \\
\text { SECTION } 2 .\end{array}$ & 1888 & 1888 & 289 & SURFACE \\
\hline 180 & MICHIGAMME MINE & W028540 & $46-32-21 \mathrm{~N}$ & 088-05-55W & $\begin{array}{l}\text { CENTER POINT OF MINED AREA S } 1 / 2 \\
\text { OF SECTION } 19 \text { AND SW OF SECTION } \\
20 .\end{array}$ & 1872 & 1905 & 935880 & UNDERGROUND \\
\hline 242 & 2 AMERICAN MINE & W062060 & $46-30-32 \mathrm{~N}$ & 087-50-10W & INCLUDES THE BOSTON LOCATION. & 1880 & 1922 & 1846643 & UNDERGROUND \\
\hline 243 & 3 ATHENS MINE & W062062 & $46-29-56 \mathrm{~N}$ & 087-35-48W & $\begin{array}{l}\text { POINT IS LOCATED AT CENTER OF } \\
\text { PROPERTY. ALSO INCLUDES } \\
\text { BUNKER HILL LOCATION. }\end{array}$ & 1918 & 1966 & 16527250 & UNDERGROUND \\
\hline 244 & 4 BESSIE MINE & W062066 & $46-30-44 \mathrm{~N}$ & 087-53-59W & & 1891 & 1906 & 59097 & 7 UNDERGROUND \\
\hline 245 & 5 BUNKER HILL MINE & W062069 & $46-29-51 \mathrm{~N}$ & 087-36-12W & $\begin{array}{l}\text { POINT LOCATED AT THE CENTER OF } \\
\text { THE PROPERTY. }\end{array}$ & $\begin{array}{l}\text { SEE } \\
\text { ATHE } \\
\text { NS } \\
\text { LOCAT } \\
\text { ION }\end{array}$ & $\begin{array}{l}\text { SEE } \\
\text { ATHEN } \\
\text { S } \\
\text { LOCAT } \\
\text { ION }\end{array}$ & 0 & UNDERGROUND \\
\hline 246 & 6 CHAMPION MINE & W062072 & $46-30-31 \mathrm{~N}$ & $087-59-04 \mathrm{~W}$ & $\begin{array}{l}\text { FORMERLY INCLUDED ALL OF S1/2 } \\
\text { OF SEC } 31 \text {. }\end{array}$ & 1868 & 1967 & 7012911 & UNDERGROUND \\
\hline 247 & 7 CHASE MINE & W062073 & $46-30-11 \mathrm{~N}$ & 087-47-11W & $\begin{array}{l}\text { INCLUDES } 80 \text { ACRES OF DEXTER } \\
\text { LOCATION WHICH IS ALSO CALLED } \\
\text { DEY LOCATION. }\end{array}$ & 1883 & 1916 & 305263 & 3 UNDERGROUND \\
\hline 248 & 8 CLIFFS ARCTIC RESERVE & W062077 & $46-30-09 \mathrm{~N}$ & 087-36-29W & $\begin{array}{l}\text { POINT LOCATED AT THE CENTER OF } \\
\text { THE PROPERTY. THE PROPERTY } \\
\text { LIES BETWEEN MAAS NEGAUNEE } \\
\text { BUNKER HILL PENDILL AND } \\
\text { MATHER PROPERTIES. }\end{array}$ & & & 200.00 & UNDERGROUND \\
\hline 249 & 9 CLIFFS SHAFT MINE & W062078 & $46-29-29 \mathrm{~N}$ & $087-40-35 \mathrm{~W}$ & $\begin{array}{l}\text { POINT LOCATED AT THE CENTER OF } \\
\text { THE PROPERTY. INCLUDES THE } \\
\text { BARNUM MORO AND BANCROFT } \\
\text { LOCATIONS. }\end{array}$ & 1868 & 1972 & 28960406 & 6 UNDERGROUND \\
\hline 251 & GOODRICH PROSPECT & W062090 & $46-27-34 N$ & $087-44-09 \mathrm{~W}$ & & 1873 & 1882 & 49754 & 4 UNDERGROUND \\
\hline 252 & LACKAWANNA MINE & W062096 & $46-29-52 \mathrm{~N}$ & $087-34-28 \mathrm{~W}$ & $\begin{array}{l}\text { POINT LOCATED AT THE CENTER OF } \\
\text { THE PROPERTY }\end{array}$ & 1886 & 1888 & 17780 & UNDERGROUND \\
\hline 253 & LAKE SALLY RESERVE & W062098 & $46-27-59 \mathrm{~N}$ & 087-38-39W & & 1865 & 1916 & 35434 & 4 UNDERGROUND \\
\hline 254 & 4 LUCKY STAR RESERVE & W062101 & $46-29-51 \mathrm{~N}$ & $087-35-24 W$ & $\begin{array}{l}\text { POINT LOCATED AT THE CENTER OF } \\
\text { THE PROPERTY. LOCATION PART OF } \\
\text { THE TRACY GROUP. }\end{array}$ & $\begin{array}{l}\text { SEE } \\
\text { TRAC } \\
\mathrm{Y} \\
\text { GROU } \\
\mathrm{P}\end{array}$ & $\begin{array}{l}\text { SEE } \\
\text { TRACY } \\
\text { GROUP } \\
\end{array}$ & 0 & 0 UNDERGROUND \\
\hline 255 & 5 MAAS MINE & W062103 & $46-30-34 \mathrm{~N}$ & $087-35-53 \mathrm{~W}$ & $\begin{array}{l}\text { POINT LOCATED AT THE CENTER OF } \\
\text { THE PROPERTY. }\end{array}$ & 1907 & 1967 & 21281386 & 6 UNDERGROUND \\
\hline 256 & 6 MARY CHARLOTTE MINE & W062105 & $46-29-00 \mathrm{~N}$ & $087-35-27 \mathrm{~W}$ & $\begin{array}{l}\text { POINT LOCATED AT THE CENTER OF } \\
\text { THE PROPERTY. INCLUDES THE } \\
\text { ALLEN. CHICAGO. EAST CHICAGO. } \\
\text { HIMROD. AND BAY STATE } \\
\text { LOCATIONS. }\end{array}$ & 1872 & 1948 & 6918663 & 3 UNDERGROUND \\
\hline
\end{tabular}


Table 1. (continued)

\begin{tabular}{|c|c|c|c|c|c|c|c|c|c|}
\hline 257 & MILWAUKEE-DAVIS MINE & W062108 & $46-29-12 \mathrm{~N}$ & $087-36-29 \mathrm{~W}$ & $\begin{array}{l}\text { POINT LOCATED AT THE CENTER OF } \\
\text { THE PROPERTY. ALSO INCLUDES } \\
\text { WHEELING LOATION. }\end{array}$ & 1879 & 1915 & 533022 & UNDERGROUND \\
\hline 258 & MITCHELL MINE & W062109 & $46-27-11 \mathrm{~N}$ & 087-41-02W & $\begin{array}{l}\text { INCLUDES THE BRAASTAD- } \\
\text { MITCHELL LOCATION }\end{array}$ & 1872 & 1913 & 233750 & UNDERGROUND \\
\hline 259 & MOORE MINE & W062110 & $46-26-11 \mathrm{~N}$ & $087-33-25 W$ & $\begin{array}{l}\text { POINT LOCATED AT THE CENTER OF } \\
\text { THE PROPERTY. ALSO INCLUDES } \\
\text { GRIBBEN AND MESABI }\end{array}$ & 1873 & 1904 & 87769 & UNDERGROUND \\
\hline 260 & NON PAREIL MINE & W062116 & $46-30-12 \mathrm{~N}$ & $087-42-47 \mathrm{~W}$ & $\begin{array}{l}\text { POINT LOCATED AT THE CENTER OF } \\
\text { THE PROPERTY }\end{array}$ & 1882 & 1887 & 23395 & SURFACE \\
\hline 261 & OGDEN MINE & W062117 & $46-27-53 N$ & $087-37-52 W$ & $\begin{array}{l}\text { POINT LOCATED AT THE CENTER OF } \\
\text { THE PROPERTY }\end{array}$ & 1897 & 1928 & 657024 & SURFACE \\
\hline 262 & PASCOE MINE & W062118 & $46-31-54 \mathrm{~N}$ & $087-57-24 \mathrm{~W}$ & & 1882 & 1886 & 59806 & SURFACE \\
\hline 263 & PIONEER MINE & W062120 & $46-29-50 \mathrm{~N}$ & 087-34-10W & $\begin{array}{l}\text { POINT LOCATED AT THE CENTER OF } \\
\text { THE PROPERTY. }\end{array}$ & 1886 & 1888 & 15409 & UNDERGROUND \\
\hline 264 & PLATT MINE & W062121 & $46-25-58 \mathrm{~N}$ & $087-34-49 \mathrm{~W}$ & $\begin{array}{l}\text { POINT LOCATED AT THE CENTER OF } \\
\text { THE PROPERTY. }\end{array}$ & 1892 & 1896 & 73844 & SURFACE \\
\hline 265 & REPUBLIC MINE & W062123 & $46-23-48 \mathrm{~N}$ & $087-58-36 \mathrm{~W}$ & $\begin{array}{l}\text { POINT LOCATED AT THE CENTER OF } \\
\text { THE PROPERTY. }\end{array}$ & 1872 & 1981 & 71522068 & $\begin{array}{l}\text { BOTH SURFACE } \\
\text { AND } \\
\text { UNDERGROUND }\end{array}$ \\
\hline 266 & RICHMOND MINE & W062125 & $46-26-14 \mathrm{~N}$ & $087-32-48 W$ & $\begin{array}{l}\text { POINT LOCATED AT THE CENTER OF } \\
\text { THE PROPERTY. }\end{array}$ & 1927 & 1955 & 4224437 & SURFACE \\
\hline 267 & ROLLING MILL MINE & W062127 & $46-29-11 \mathrm{~N}$ & $087-35-52 W$ & $\begin{array}{l}\text { POINT LOCATED AT THE CENTER OF } \\
\text { THE PROPERTY. INCLUDES KRUSE } \\
\text { LOCATION. }\end{array}$ & 1871 & 1935 & 2997802 & $\begin{array}{l}\text { BOTH SURFACE } \\
\text { AND } \\
\text { UNDERGROUND }\end{array}$ \\
\hline 268 & SALISBURY MINE & W062130 & $46-28-22 \mathrm{~N}$ & $087-40-03 W$ & $\begin{array}{l}\text { POINT LOCATED AT THE CENTER OF } \\
\text { THE PROPERTY. }\end{array}$ & 1872 & 1924 & 4489102 & UNDERGROUND \\
\hline 270 & VOLUNTEER MINE & W062135 & $46-26-48 \mathrm{~N}$ & $087-36-55 \mathrm{~W}$ & $\begin{array}{l}\text { POINT LOCATED AT THE CENTER OF } \\
\text { THE PROPERTY. SECTION } 25 \\
\text { PROPERTY IS VOLUNTEER; SECTION } \\
30 \text { PROPERTY IS MAITLAND. }\end{array}$ & 1926 & 1960 & 5377223 & SURFACE \\
\hline 271 & WICKS PROSPECT & W062138 & $46-25-56 \mathrm{~N}$ & 087-34-31W & $\begin{array}{l}\text { POINT LOCATED AT THE CENTER OF } \\
\text { THE PROPERTY. }\end{array}$ & 1882 & 1882 & 196 & \\
\hline 272 & WINTHROP MINE & W062139 & $46-27-11 \mathrm{~N}$ & 087-41-30W & & 1870 & 1903 & 2590560 & UNDERGROUND \\
\hline 285 & MARQUETTE DISTRICT & W001391 & $46-27-11 \mathrm{~N}$ & 087-41-30W & $\begin{array}{l}\text { MARQUETTE IRON DIST. CONTAINS } \\
\text { AROUND } 125 \text { MINES. MOST ARE } \\
\text { NOW EXTINCT BUT THOSE } \\
\text { OPERATING ABOUT TO OPERATE OR } \\
\text { RECENTLY CLOSED HAVE BEEN } \\
\text { WRITTEN UP SEPARATELY. }\end{array}$ & 1848 & $\begin{array}{l}\text { STILL } \\
\text { ACTIV } \\
\text { E }\end{array}$ & 587641341 & \\
\hline 289 & HUMBOLDT & W001396 & $46-29-24 \mathrm{~N}$ & 087-54-00W & $\begin{array}{l}\text { POINT LOCATED AT THE CENTER OF } \\
\text { THE OPEN PIT, EARLIER OPERATION } \\
\text { (1865-1892, 1908-1917) CONTAINED } \\
\text { SAMPSON AND WASHINGTON } \\
\text { LOCATIONS SEE THOSE MINES FOR } \\
\text { PRODUCTION STATISTICS. }\end{array}$ & 1954 & 1972 & 9433305 & SURFACE \\
\hline 290 & EAST CHAMPION & W062081 & $46-30-36 \mathrm{~N}$ & 087-57-36W & $\begin{array}{l}\text { POINT LOCATED ON THE CENTER OF } \\
\text { THE PROPERTY }\end{array}$ & 1872 & 1889 & 76002 & UNDERGROUND \\
\hline
\end{tabular}




\section{END NOTES}

\footnotetext{
${ }^{1}$ Swineford, A.P. 1876. History and Review of the Copper, Iron, Silver, Slate, and Other Material Interests of the South Shore of Lake Superior. Marquette, (LS.)

Michigan, the Mining Journal, p.3

${ }^{2}$ Charles Penny described one night there in: Carter, James L. and Rankin, Ernest $\mathrm{H}$. (editors). 1970. North to Lake Superior, The Journal of Charles W. Penny, 1840 The John M. Longyear Research Library, Marquette MI, p. 8, stating from Saturday, May $30^{\text {th }}$, 1840: "Last evening we had a most splendid display of Northern lights. At 10 o'clock the whole heavens appeared to be in a blaze-streaks of light flashed up toward the zenith from every part of the horizon, and we could read a newspaper very well. It exceeded in brilliancy anything of that kind that I had ever seen."

${ }^{3}$ Brooks, T.B. 1873. Iron Bearing Rocks of the Upper Peninsula of Michigan. (Two Volumes) Julius Bien, New York. Michigan Geological Survey Report for 1869-1873. v.1 p.9

${ }^{4}$ Brooks, Iron Bearing Rocks, v.1 p.10

${ }^{5}$ Ibid., p. 11

${ }^{6}$ Ibid., p.11

${ }^{7}$ Fuller, George N. (Editor) 1928. Geological Reports of Douglass Houghton: First State Geologist of Michigan, 1837-1845 The Michigan Historical Commission, Lansing. p. 526

${ }^{8}$ Carter, James L. and Rankin, Ernest H. (editors). 1970. North to Lake Superior, The Journal of Charles W. Penny, 1840 The John M. Longyear Research Library, Marquette MI, p. 7

${ }^{9}$ Peters, Bernard C. (Editor) 1983. Lake Superior Journal: Bela Hubbard's Account of the 1840 Houghton Expedition Northern Michigan University Press, Marquette. p.19

${ }^{10}$ Fuller, Geological Reports of Houghton, p. 42

${ }^{11}$ Peters, Lake Superior Journal: Bela Hubbard, p. 29.

${ }^{12}$ Schoolcraft, H.R. 1820. Narrative Journal of Travels through the Northwestern Regions of the United States Extending from Detroit through the Great Chain of American Lakes to the Sources of the Mississippi River in the year 1820 in: the 1999 Lake Shore Observer, publication of the National Park Service at Pictured Rocks National Lakeshore.

${ }^{13}$ Fuller, Geological Reports of Houghton, p.475

${ }^{14}$ Carter, North to Lake Superior, The Journal of Charles Penny, p. 28

${ }^{15}$ Peters, Lake Superior Journal: Bela Hubbard, p.47

${ }^{16}$ Ibid., p.47

${ }^{17}$ Fuller, Geological Reports of Houghton, p.494

${ }^{18}$ Ibid., p.475

${ }^{19}$ Ibid., p.486

${ }^{20}$ Ibid., p.527

${ }^{21}$ Ibid., p.527 and 547

${ }^{22}$ Brooks, Iron Bearing Rocks, v. 1 p. 11
} 
${ }^{23}$ Fuller, Geological Reports of Houghton, p.476

${ }^{24}$ Brooks, Iron Bearing Rocks, v. 1 p. 12

${ }^{25}$ Swineford, History and Review, 1876, p.91

${ }^{26}$ Ibid., 92

${ }^{27}$ Brooks, Iron Bearing Rocks, v. 2 p. 237

${ }^{28}$ Swineford, History and Review, 1876, p. 95

${ }^{29}$ Ibid., p.96

${ }^{30}$ Swineford, History and Review, 1876 p.96

${ }^{31}$ Swineford, A.P. 1869. The Lake Superior Iron District. History of its Mines and

Furnaces Marquette, p.5.

${ }^{32}$ Ibid., 7.

${ }^{33}$ Brooks, Iron Bearing Rocks, v. 2 p.16

${ }^{34}$ Swineford, The Lake Superior Iron District, 1869 p.10.

${ }^{35}$ Benison, Saul. 1953. Railroads, Land and Iron; A Phase in the Career of Lewis Henry Morgan Ph.D. Dissertation, Columbia University, p.58.

${ }^{36}$ This updating and verification of MRDS records was performed by the author mostly based on information from: Lake Superior Iron Ore Association. 1952. Lake Superior Iron Ores: Mining Directory and Statistical Record of the Lake Superior Iron Ore District of the United States and Canada Second Edition, Published by the author, Cleveland Ohio with extensive help from Bill Cannon. This information will be present in the open file report of the geologic map of the Penokean Continental Margin upon its publication.

${ }^{37}$ Foster, J.W., Whitney, J.D., 1851. Report on the Geology of the Lake Superior Land District, Part II, The Iron Region, Together with the General Geology. Senate Executive Document Number 4. A. Boyd Hamilton, Washington. p. iv

${ }^{38}$ Buyom, Burton. 1991, Chapter 1, Iron Mining In: Mulligan, William H., editor and contributor. Historical Resources of the Iron Range of Marquette County, Michigan, 1844-1941. The Economic Development Corporation of the County of Marquette, p. A-5, A-6

${ }^{39}$ Boyum, Burton H., and Reed, Robert C. 1988. Marquette Mineral District of Michigan with emphasis on Mining History and Geology: Thirty Fourth Annual Institute on Lake Superior Geology, Field Trip Guidebook Volume 2., p. B-2

${ }^{40}$ Ibid., p. A7-A12. Cross sections come from p. A-12

${ }^{41}$ Ibid., p.A-7

${ }^{42}$ Rominger, C. 1881. Geologic Survey of Michigan. Upper Peninsula, 1878-1880 Volume IV. Published

by the Authority of the Legislature of Michigan, Under the Direction of the Board of Geologic Survey.

Julies Bien, New York. p. 73

${ }^{43}$ Brooks, Iron Bearing Rocks, v. 1 p. 117

${ }^{44}$ Foster and Whitney, Report on the Geology, p.55

${ }^{45}$ Brooks, Iron Bearing Rocks, v. 1 p. 245

${ }^{46}$ Rominger, Geologic Survey, p. 72

${ }^{47}$ Foster, J.W. in: Benison, Railroads, Land, and Iron, p. 51 
${ }^{48}$ Benison, Railroads, Land, and Iron, p. 94

${ }^{49}$ Ibid., p. 94

${ }^{50}$ Ibid., p. 95

${ }^{51}$ Houghton, J. jr., and Bristol, T.W., 1846. Reports of Wm. A. Burt and Bela Hubbard, Esqs. on the Geography, Topography, and Geology of the U.S. Surveys of the Mineral Region of the South Shore of Lake Superior, For 1845; Accompanied by a list of working and organized mining companies; a list of mineral locations; by whom made, and a Correct Map of the Mineral Region, delineating the township and section lines, and their connection with the location lines; and also, a Chart of Lake Superior, reduced from the British Admiralty Survey Detroit: Printed by Charles Willcox. p. 25.

${ }_{53}^{52}$ Buyom and Reed, Marquette Mineral District, p. B-5

${ }^{53}$ Buyom, Iron Mining, p. A-10

${ }_{55}^{54}$ Buyom and Reed, Marquette Mineral District, p. B-5

${ }^{55}$ Brooks, Iron Bearing Rocks, v. 1 p. 245

${ }^{56}$ Buyom and Reed, Marquette Mineral District, p. B-5

${ }^{57}$ Ibid., p. B-5

${ }^{58}$ Brooks, Iron Bearing Rocks, v.1., p. 246

${ }^{59}$ Rominger, Geologic Survey, p. 75

${ }^{60}$ Foster, J.W. 1865. Geology and Metallurgy of the Iron Ore of Lake Superior: Being a Report Addressed to the Board of Directors of the Iron Cliffs Company. Bryant and co. Printers, New York. p. 9

${ }^{61}$ Rominger, Geologic Survey, p. 75

${ }^{62}$ The Mid-Peninsula Library Federation. 1883. History of the Upper Peninsula of

Michigan: containing a full account of its early settlement, its growth, development, and resources, an extended description of its iron and copper mines. Also, accurate sketches of its counties, cities, towns and villages Western Historical Co., Chicago, p. 400

${ }^{63}$ Foster, Geology and Metallurgy, p. 34

${ }^{64}$ Foster, Geology and Metallurgy, p. 34 and Brooks, Iron Bearing Rocks, v.1 p. 258-268

${ }^{65}$ Brooks, Iron Bearing Rocks, v. 1 p. 244

${ }^{66}$ Whitaker, J. Russell. 1931. Negaunee, Michigan; An Urban Center Dominated by Iron Mining. The Bulletin of the Geographical Society of Philadelphia, V.XXIX, August, 1931, p.40

${ }^{67}$ Brooks, Iron Bearing Rocks, v.1 p. 247

${ }^{68}$ Ibid., p. 262

${ }^{69}$ Brooks, T.B. 1873. Plate VIII. Furnaces Consuming L.S. Ores, Production of Pig Iron, Metallurgical and Chemical Character of Ores in Brooks, Iron Bearing Rocks, v.1

${ }^{70}$ Brooks, Iron Bearing Rocks, v. 1 p. 264

${ }^{71}$ Ibid., p. 264

${ }^{72}$ Foster, Geology and Metallurgy, p. 35

${ }^{73}$ Brooks, Iron Bearing Rocks, v. 1 p. 248

${ }_{75}^{74}$ Ibid., p. 267 and Foster, Geology and Metallurgy, p. 35

${ }^{75}$ Brooks, Iron Bearing Rocks, v.1 p. 277

${ }^{76}$ Ibid., p. 271

${ }^{77}$ Mid-Peninsula Library Federation, History of the Upper Peninsula, p.400 
${ }^{78}$ Swineford, A.P. 1881. Annual Review of the Iron Mining and Other Industries of the Upper Peninsula For the Year Ending Dec., 1880 Mining Journal, p. 7

${ }^{79}$ Swineford, Annual, 1880 p.25 and 92

${ }^{80}$ Mid-Peninsula Library Federation, History of the Upper Peninsula, p. 394, 402

${ }^{81}$ Swineford, The Lake Superior Iron District, 1869 p.34.

${ }^{82}$ Numbers based on MRDS data.

${ }^{83}$ Alanen, A.R., 1991. Chapter 9, The Settlements of Marquette County, Michigan In:

Mulligan, William H., editor and contributor. Historical Resources of the Iron Range of Marquette County, Michigan, 1844-1941. The Economic Development Corporation of the County of Marquette, p.3

${ }_{85}^{84}$ Benison, Railroads, Land, and Iron, p. 58.

${ }^{85}$ Ibid., p. 84

${ }^{86}$ Ibid., p.66

${ }^{87}$ Ibid., p. 67

${ }^{88}$ Ibid., p.70

${ }^{89}$ Ibid., p.71, 72

${ }^{90}$ Ibid., p.73

${ }^{91}$ Buyom, Iron Mining, p. A-18

${ }^{92}$ Brooks, Iron Bearing Rocks, v.1 p. 248 and Whitaker, Negaunee, p. 32

${ }^{93}$ Buyom, Iron Mining, p. A-16

${ }^{94}$ Whitaker, Negaunee, p. 33 and Benison, Railroads, Land, and Iron, p. 315

${ }^{95}$ Mid-Peninsula Library Federation, History of the Upper Peninsula, p.401

${ }^{96}$ Ibid., p. 401

${ }^{97}$ Swineford, Annual, 1880 p. 24

${ }^{98}$ Ibid., p. 73

${ }^{99}$ Swineford, The Lake Superior Iron District, 1869 p.13

${ }^{100}$ William Cronon, Changes in the Land: Indians, Colonists, and the Ecology of New England. (New York, 1983), preface, vii.

${ }^{101}$ Rominger, Geologic Survey, p. 87

${ }^{102}$ Whitaker, Negaunee, p. 76. 


\section{CONCLUSION}

Upon my arrival on the Marquette Range, following my flight from Washington D.C., I stood on the runway at the Marquette County airport on a pleasant and sunny, though windy day. Driving a rental car, the ride east and downhill from the airport toward Lake Superior and into the city of Marquette on U.S. Route 41 was a short one. On both sides of the road were large chain stores and fast food restaurants all very recently built. At several times along the drive the water of Lake Superior came into our view, beautiful and bright blue on the clear day. After a short ride we reached town and pulled into a Ramada to begin our stay. After I had settled in my room and gazed out at the city from my window in the hotel, I embarked on a walk through town; as I neared the downtown area, I glimpsed Mt. Mesnard, a ridge of white quartzite outcropping as a high point just south of town and decided to try to hike it. Although I was unaware of any way of getting on top of the ridge, from there, I supposed, would be a good view of my surroundings. I had a few hours to kill, and the ridge had come up commonly in the reading I had done of the area; I couldn't pass up the temptation of the walk.

Along main street, passing Remies Tavern on my right and the large construction project of the Peter White Library up the hill on my left, I walked into the oldest and most historical part of Marquette. The downtown area sits on a rather steep hill facing south, the hill leading into the low ground where Mona Schist is the bedrock. As I walked toward the lake I looked between city blocks out past city hall and over several other buildings and houses and could see the bright white quartzite outcrops on Mt. Mesnard, distinct near the top of the hill. I turned right and walked downhill past the Vierling restaurant and brewery on my left, crossing under a railroad overpass that at one time allowed access for trains to the iron ore pocket docks. I was very near the lakeshore and continued my hike past a statue of Pierre Marquette. Near the lake was a strip of land that by its appearance had served many purposes throughout the life of this city. Trash was common along this vacant stretch. It was difficult to tell if the glass shards 
were from broken bottles or perhaps iron production refuse, diverted molten impurity, solidified, discarded and forgotten. Several layers of culture were present along this abandoned strip of land near the ore dock. The land had served many different purposes since men such as Marjijesick, Douglass Houghton, William Burt and Philo Everette walked near here over 150 years ago.

Continuing my walk with Mesnard as my goal I crossed over the very busy southward bound road between a hamburger and pizza restaurant and started weaving my way through city blocks, houses, occasional stores and, eventually, the subdivisions of southern Marquette. After a great deal of walking I made it to the outskirts of town. Walking steadily uphill, the trees became more dense and buildings more sparse, as I passed from the platted city blocks into the winding subdivisions. At a trailer park I took a left and headed, as closely as I could guess, toward the top of Mt. Mesnard now obscured by trees and closer hills. The terrain was getting steeper and my muscles tightened as I walked toward the ridge guessing at the directions I should take in the subdivided, curving streets and evenly spaced, recently built homes with landscaped yards and blacktop driveways. Through the subdivision the road I walked upon was now a narrow stretch of black top, seemingly rarely used, quiet and without a center stripe.

Attempting to remain as consistent with the direction I supposed the white outcrops of Mt. Mesnard to be in, I began to work against the trend of the subdivision street crossing through quiet yards to remain in the uphill direction. Walking away from the houses and yards the forest of large trees grew dense with only paths made by children present. Unfortunately, none of the paths traveled in my preferred direction so I continued through the mid-successional mixed hardwood forest rustling leaves and trying to avoid dense patches of undergrowth. The hardwoods were mostly young maples, birch and occasional aspens. The hot dry smell of pine needles became noticeable when I walked near a softwood stand; red and jack pines grew occasionally in the shade of the ravines and under the canopy. The only sounds were the chattering of insects. As I walked I continually ran into spider webs, and had to carry a small stick to knock them 
down. Here, with the true beginning of Mt. Mesnard, the terrain became quite steep and incised by dry, surprisingly deep ditches.

The closer I came to the top of the rise, the larger the boulders of quartzite covered with moss present in the forest became. The walk became arduous. The dry watercourse incisions into the hill side, valleys in the ridge, became perpendicular to my preferred direction and I was forced to choose between staying my course, sacrificing elevation gained and sliding on loose soil down into low ground or changing my direction to stay on the high ground as I, now circuitously, attempted to gain elevation and the ridge.

Perhaps 20 minutes after I had left the subdivision behind, after climbing uphill in various directions, I began the final ascent of Mt. Mesnard. At times the hill was steep enough that I had to grab onto small trees to help me climb. I arrived at an outcrop of quartzite 20 feet in height that I had to partially climb, partially work my way around before I could get on top. I emerged into the sunlight and open area of the top of the quartzite ridge through a crack in the very hard rock. The view was beautiful in every direction; looking down onto the city of Marquette toward the north, and out on the flat rocks of the eastern Upper Peninsula to the south and east. The Mesnard quartzite that outcropped on the ridge was, likewise, beautiful. The white, very clean, almost glassy rock, fractured in places, was very smooth. Glaciation in the area left very evident grooves in the quartzite, and I marveled at the smoothness and polish that the glaciers had accomplished. Though I saw no evidence of such, this quartzite was mined for centuries by the Indians of the area to create tools and hunting implements. Stunted Jack pines grew in the few places there was sufficient soil on the top of the ridge along with small scrubby service berry (amelanchier spp.).

The rocky and prominent ridge I stood on that windy day in early May, was visited 159 years before by the Houghton Expedition of 1840 . The ridge then was also a barren peak of quartzite. Charles Penny wrote of Mt. Mesnard: "The top...is composed almost entirely of white quartz, and is elevated near three hundred feet above the lake. The upper surface of the rock is worn, as if immense weights had been drawn over it. It 
is almost as hard as flint, and consequently retains perfectly all these little creases, hollows and scratches."1

The top of Mt. Mesnard is more of a ridge than peak. The part I stood on was the highest part of the ridge that stretches from Teal Lake, where it outcrops nicely along the shores of the lake, and runs over many miles east, beyond where I stood that day in early May, out into Lake Superior. A dirt road runs along the top of the ridge, and a very primitive lookout is present where I stood at the highest part of the ridge, with a few rotting picnic tables and a rusting railing on the edge of the outcrop. On the highest point of Mesnard, amongst the scraggly trees, is a small and rather old looking transmitter tower, rusting with age and beaten by the wind.

The views from Mt. Mesnard were very nice, and it provided a lovely spot for me to look out and ponder the history of the landscape of the Marquette Range. To the east Lake Superior, beautiful on the bright, clear, windy day was choppy and blue, forming the horizon to the northeast. I peered through the distance to where the lake met the sky, trying to see some distant rock island or ore carrier but saw nothing. Following the hazy line between water and atmosphere, gray land of the eastern Upper Peninsula disrupted the blue far off to the east. I did not perceive the features of Grand Island, the Pictured Rocks, or the Grand Sable Dunes, but with the sweep of the vista and the clarity of the day I could see areas far along the shore to the east. Leafless brown trees were everywhere on land of the eastern U.P., only a few recognizably human features were noticeable. The slight, wooded hills rising out of the Keweenawan and Paleozoic sandstones of the eastern Upper Peninsula looked quite natural with few signs of the intense logging that had occurred there for over a century.

Toward the southwest, facing the Southern Complex gneiss and migmatitic gneiss terrain that bounds the Marquette Synclinorium, a stiff wind blew in my face. The consistency and strength of the breeze allowed me to lean out over the edge of the quartzite, over a fairly steep precipice, the wind hard enough to give me confidence near the edge. Below me was the Marquette Ski Hill, still with bright white snow on the brown and gray hillside, on the runs near the bottom where the sun hit the hill least. 
Beyond the swaths of treeless area cut into the woods of the hill, looking out at the southern Marquette Range, toward Palmer and the present day mining operations, I could see only a peaceful and beautiful terrain, seemingly barely marked by human hands, with numerous dense stands of leafless trees on ridges with occasional outcrops of gray rock. I looked closely for signs of human alteration, but beyond the immediate ski hill, a few power lines, and roads I could see none.

The view to the north was out over the city of Marquette encompassing the many ridges of gneissic rock, with forests toward Huron Bay, and the Abbaya and Keweenaw Peninsulas far to the northwest. From my vantage I could see the curving shore of Marquette Bay, framed by two large coal burning, electric generating power plants with tall smoke stacks, on the north and south ends of the town. The city extends out of the low ground on the complex and reworked Mona Schist, exposed in only a few places, up onto a hill of amphibolite, and then down again into northern complex gneiss. The city blocks of Marquette with older historical buildings, many of which were built with distinct dark reddish Jacobsville Sandstone, ignore the precipitous terrain of the area and were built straight, masking the complex and hilly rocks the city was built upon. City Hall, very distinct on a small hill of the downtown area, stood out in the view with railroad tracks running very near the building and on out onto a dock running out over the water. From the dock, following the curving shoreline past the steep hill of the older part of town, Northern Michigan University with its distinct domed ice hockey arena is north of downtown Marquette; much of it was hidden from my vantage. Along the rocky shore, farther to the north, another large dock jutted out into the blue expansive lake. This is the active dock in Marquette, beyond it and the second power plant lay Presque Isle, much higher than the rest of the shore with steep cliffs and thick woods. Five or six islands, many of them only barely more than rock outcrops with scrubby vegetation are spread out near the shore of Presque Isle.

Beyond the many buildings of the town stand the wooded hills of the northern complex and the Huron Mountains; forested ridges with bare, weathered peaks stretching to the northern horizon. Sugarloaf and Hogback Mountains, two prominent features 
beyond the town, stand out as topographic highpoints, exposing gray rock summits. Straining my eyes beyond the two hills, again I could see no major signs of human disturbance. I saw a few odd treeless patches amongst the parallel ridges but, for the most part, the area looked as it must have looked to the first explorers who came to the area; wooded ridges of gneiss with rocky outcrops extending, uninhabited, northwest to Lake Superior.

In many ways when I looked beyond the buildings of Marquette in the foreground, gazing out at the wooded hills and barren ridges of the Huron Mountains and the Marquette Range I saw what Douglass Houghton, Bela Hubbard and Charles Penny must have seen when they climbed Mt. Mesnard in 1840. Houghton wrote of the view: "This country is made up of a series of irregular, knobby ranges of hills, that have a general easterly and westerly direction, with intervening valleys of flat or gently rolling land...(the terrain consists of) ranges of broken hills, with knobs not unfrequently nearly or quite destitute of timber." ${ }^{2}$ Bela Hubbard wrote of the view northwest from Mesnard that the area consisted of: "a country of rolling hills, with higher primary knobs...[and] intervening smaller ridges filling up the intervals. A mixture of timber...exists here, the evergreens predominating. Much fine birch grows. In the intervening meadow lands (if they may be so called) are seen masses of maple with bass and some other timber."3 Charles Penny wrote of the area I viewed so many years later: "In the west rose a succession of granitic knobs, one above another as far as the eye could extend. These peaks are sharp and but scantily covered with scrubs of evergreen." 4 The consistency of the forest has changed, the land has been bounded and settled, however the land's generally appearance has not changed dramatically since pre-major settlement.

This has not always been the case. One hundred years ago, at the end of the $19^{\text {th }}$ century, if a person had stood on a high point on the Marquette Range and noted the surroundings, the panorama would have been quite different. At that point, 50 years of intensive logging, mostly to create charcoal to supply the pig iron production blast furnaces, had devastated and decimated the forests of the Range. The terrain had been razed by the settlers of the $19^{\text {th }}$ century Range; cut-over was endemic to all but a few 
small parcels of land. Photographs from this era show the wholesale destruction of the forests. The demand for the timber for production of iron was so voracious that everything that could be burned was burned. William Gwinn Mather estimated in 1902 that 160,000 acres, or 250 square miles of woodland were cut to supply the kilns of the Upper Peninsula in the $19^{\text {th }}$ century. ${ }^{5}$ The majority of this iron production, and deforestation, was centered on the Marquette Range. Using Gwinn's numbers we arrive at figures of 10,000 acres of trees clear-cut per year and 30 acres cut per day. For every 14 tons of pig iron produced, one acre of timber was slashed. The prosperity of the $19^{\text {th }}$ century iron industry on the Marquette Range came at the cost of its forests, and barren hills and a cropped terrain were the results. What was not cut purposefully for economic profit was often times subjected to accidental fires, common throughout the period. It is estimated that 20 percent of the 380 billion board feet of timber in the state of Michigan was lost to fires. ${ }^{6}$

Amazingly, following the devastation wrought, the trees of the Marquette Range grew back. The character of the forest had radically changed with the distribution of the species shifted and new species introduced. However, in general, after half a century or more of rebound, the appearance returned to that of the pre-major settlement wooded region. There is little aesthetic evidence one can gather, staring from a high point on the Range that the land was at one time nearly entirely clear-cut.

The forest was allowed to return to the Marquette Range. Both changing economic and cultural factors were related to its return. Slowly over the course of the $19^{\text {th }}$ century, charcoal fired iron producing furnaces gave way to large coal fired furnaces, and the large demand for wood to create charcoal subsided. The end of shaft mining, not occurring completely until the 1950's brought about the end of the need for supports within the mine. More difficult to recognize and quantify is the change in cultural consciousness that occurred over many years in the $20^{\text {th }}$ century. Society has become less willing to destroy nature for the success of individuals. Diversification of economy has also played a role in the paradigm shift on the Marquette Range. 
Although the lack of a lucrative market and a growing concern for the environment helped the forests of the Marquette Range to return, iron mining on the Range, conversely, has increased greatly since the $19^{\text {th }}$ century in its extensiveness and destruction of the landscape. Although at the height of surface mining activity on the Range in the 1870's and 1880's scores of companies were blasting away at the iron formation, and millions of tons of iron ore were removed from the earth, their effect on the land was greatly limited compared to the activity of the present mining. In terms of production numbers the Jackson and Lake Superior mines, two of the largest and longest active mines on the Range, beginning in the mid- $19^{\text {th }}$ century and extending into the 1920 's and 1930's, produced 4.5 and 25 million tons, respectively. Both of these mines lasted for over 80 years, beginning with surface mining and then progressing deep beneath the earth to continue the extraction. ${ }^{7}$ The total amount of high grade naturally concentrated ores mined from all of the mines of the Marquette Range from the mid- $19^{\text {th }}$ century to the mid- $20^{\text {th }}$ century was $301,050,514$ tons. ${ }^{8}$ Comparing these numbers to the present day Empire taconite mine we see how much more acute the extraction has become. Improvements in technology during the 1950's in the processing of low grade taconite ore, long considered worthless compared to the high grade ore mined since the opening of the Range, allowed for large scale open pits to be built in the area, resurrecting the quarry approach of blasting, and then scooping up the blasted fragments of ore. Since opening in 1963, the Empire, one of two open pit operations presently in operation on the Range, has produced 200 million tons of taconite pellets. Working from the current production efficiency of 8.4 million tons of pellets for every 27.5 million tons of taconite ore mined, the amount of ore removed by the mine equals 5.5 billion tons. ${ }^{9}$ Not all of the material removed from the pit is ore and for every 8 million tons of pellets, 65 million tons of material is removed. ${ }^{10}$ Using these figures roughly 13 billion tons of material has been removed from the Empire mine. The waste rock is piled onto very large mountains of debris around the mine. Compared with the extraction of the $19^{\text {th }}$ century, the present day mining on the Range has reached an entirely new order of magnitude. 
Before the high grade hard ore deposits on the surface were depleted in the late $19^{\text {th }}$ century many of the open pit mines of the numerous companies extracting ore from the Range grew to a large size. Several of the pits were greater than 100 feet deep and some extended over thousands of feet in length. When the size of these historical workings are compared with the Empire, however, they seem quite insignificant. The Empire mine is 800 feet deep and planned to be enlarged to twice that amount. The main pit is a massive canyon, several square miles in size. Several other pits attached to the main pit are also very large in size. Eventually all of these pits will be connected into one gigantic hole. The mine is of such a scale that several historical mining locations on the Range have been swallowed up by the current activity.

Actions driven by the profit of society, often heavily weighted toward select individuals within that society, possible through naturally provided commodities, and pervading extraordinarily high and difficult to measure costs to nature, are at the heart of capitalism. This economic system, defined by, and extremely transformative of nature is still alive and well on the Marquette Range. Since the first mines and settlements of the Range began, the maximization of select commodities, particularly iron and timber, for capital profit has been essential to the societies' workings. As efficiency has increased, aided by technological improvements, and driven by market demand, the manipulation of the natural systems has increased. With the diversification of economies on the Marquette Range since the middle of the $20^{\text {th }}$ century, the connection between nature and history on the Range are more obscure, however it is still a direct relationship. Although the Marquette Range is not entirely reliant upon iron ore and timber for its existence, as it almost exclusively was in the $19^{\text {th }}$ century, iron deposits still play a very large part on the Range. The close ties to the distribution and nature of the ore means that the recent history of the area is still an incredibly ancient history.

As part of the Institute on Lake Superior Geology's $45^{\text {th }}$ Annual Meeting, I was able to see first hand the present mining on the Marquette Range during a field trip to the Empire mine. The field trip was fascinating and in many ways was the culmination of all 
I had learned and written about concerning the Marquette Range. Despite the large size of the mine and its associated operations, it is difficult to get a clear view of the pits themselves. This is similar with the Tilden mine which is an equally large operation that is so near the Empire that the two could be considered one operation. The mountains of waste rock surrounding the sites are visible from a great number of places on the Range, however the pits which are south of Negaunee and Ishpeming and are on large tracts of privately owned land, can be seen only from the air or on a tour.

The day of the field trip was rainy and cold. The clouds were very low, reducing visibility considerably, and as they moved across the sky the rain would start and stop; sometimes it was quite heavy, but mostly it just drizzled. The weather, however uncomfortable to be out in, was welcomed, as it played a large role in putting out the fires I had seen from the airplane on the ride in that had caused a great deal of damage to the forests near Republic and Champion. Driving through the rain we passed several very large piles of rock too low in iron content to be processed as iron ore that had been separated from the ore being turned into pellets. The very tall piles of red and gray refuse rock have flat tops and sloping sides, and take up large amounts of area at the mine. It is estimated that very soon one of these piles will become the highest point in Michigan. After driving through the piles, and around many buildings associated with the processing of the taconite ore into pellets, many of them flat and cylindrical, one conic, we had a preliminary introduction to the site, and were brought to the edge of the chasm.

The mine was absolutely stunning. What lay before us was a completely alien landscape. Within the mine dark gray and hematite red rock is everywhere, the only vegetation present is scrubby and very sparse trees on the edge of the amazing precipice. The main pit of the mine, on the edge of which we stood, is perfectly immense. The opposite edge was at least a mile away, and with the oblong form we looked across one of the more slender parts. Large vehicles on the opposite side, and working within the pit looked like toys. Walls plummet down into the great hole as giant stairs to the bottom. Although each step measures 50 feet in height there are scores of them that extend down to the level currently being worked. The low clouds drifted in and then out of the pit, 
with the sound of machinery, working at the bottom, a distant but consistent metallic intone. One lake gull flew amidst the dark rock and mist, very white and tiny in the vast amount of space.

After gaping open mouthed at the main pit, just one of several pits at the Empire mine, which will one day be connected into a pit twice as deep, we drove down into the mine on a spiraling bench slowly dropping, along the edge of the mine, to the bottom. On our way down we drove past massive dump trucks, the size of small houses with twelve foot tall wheels and staircases to the cabs. There are two types of these massive trucks, one 170 tons in weight, the other 240 tons. At the bottom of the pit a large electric powered shovel scooped up 50 tons of loose rock at a time in its 33 cubic yard bucket, emptying the material into the waiting trucks. Two drill rigs were also present at the bottom, drilling evenly spaced holes 50 feet deep. Into the many holes drilled into each bench is put an explosive consisting, in large part, of fertilizer, which typically throws down 550,000 tons of material in one concerted blast, that will later be scooped, transported, separated and processed. ${ }^{11}$

It is amazing how similar the processes I witnessed that day at the Empire Mine were to the original surficial workings on the Range. In the creation of the stopes and ledges the rotary drill rig has taken the place of the hammer driven drill, turned by one man sitting and struck by two man standing. For loosening and throwing down the ore and country rock, powder and nitroglycerine has been replaced by fertilizer. Men breaking apart the ore and shoveling it into carts has been replaced by the electric shovel and separating techniques during processing. The massive dump trucks now transport the ore that was once handled by horses and locomotives.

At the bottom of the pit I looked up at the edges and felt extraordinarily small. Only in places such as the Grand Canyon, Hells Canyon, Copper Canyon had I been in such a hole. Our tour was soon over, and once off the mine property it was impossible to tell that such a major operation was occurring there. Driving back into Marquette the rain stopped, the sun came out, and the rest of the day was quite pleasant. 
From the tour I realized that the operations and approach of resource extraction on the Marquette Range is still quite similar to the processes that occurred 150 years ago. Select commodities are maximized at the highest, most economical level possible as determined by an abstract market. Only the scale has changed, as technological improvements have increased mans ability to manipulate at an increasingly more efficient manner, and as an ever expanding economy has created more demand for the product.

The market demand for naturally provided commodities will, in very important ways, determine the future of the Marquette Range, just as it has defined the past. Defined by the geological and ecological melange, man has profited because of, and often at the cost of, those natural systems, and there is little evidence that this system will change. The history of the Marquette Range is a history of rocks and trees and is an incredibly ancient history. The human history of the Range, one infinitesimally small moment in the spectrum of the area's existence is, likewise, a history of rocks and trees. This thesis has looked at how the geology and ecology have been, and are interrelated with the workings of society on the Range. As nature defined humanity, as it still does today, humans reworked the natural features in continuing, ever increasing, destructive, and often irrevocable ways. This is the history of the Marquette Range. 


\section{END NOTES}

${ }^{1}$ Peters, Bernard C. (Editor) 1983. Lake Superior Journal: Bela Hubbard's Account of the 1840 Houghton Expedition Northern Michigan University Press, Marquette. p.28

${ }^{2}$ Fuller, George N., Editor. 1928. Geological Reports of Douglass Houghton: First State Geologist of Michigan, 1837-1845 The Michigan Historical Commission, Lansing. p.486

${ }^{3}$ Peters, Lake Superior Journal, p.47

${ }^{4}$ Carter, James L. and Rankin, Ernest H. (editors). 1970. North to Lake Superior, The Journal of Charles W. Penny, 1840 The John M. Longyear Research Library, Marquette MI.p.34

${ }^{5}$ Mather, William Gwinn. 1903. Paper presented at the $9^{\text {th }}$ Annual Meeting of the Lake Superior Mining Institute.

${ }^{6}$ Whitney, Gordon G. 1994. From Coastal Wilderness To Fruited Plain: A History of Environmental Change in Temperate North America 1500 to Present. Cambridge University Press, New York. p.198

${ }^{7}$ MRDS data, see Table 4-1

${ }^{8}$ Boyum, Burton H., and Reed, Robert C. 1988. Marquette Mineral District of Michigan with emphasis on Mining History and Geology: Thirty Fourth Annual Institute on Lake Superior Geology, Field Trip Guidebook Volume 2., p. B-5

${ }^{9}$ Nordstrom, Paul M. 1999. Geologic Field Trip to the Empire Mine. Forty-Fifth Annual Institute on Lake Superior Geology, Field Trip Guidebook. p. 129

${ }^{10}$ Pamphlet created by the Empire Iron Mining Partnership, Palmer, Michigan.

${ }^{11}$ Ibid. 


\section{REFERENCES}

Anderton, John B. 1998. The Red River Prior to Major American Settlement: A Cultural Landscape Created by Native American Landscape Burning. North Dakota Quarterly, V.65, No.4.

Benison, Saul. 1953. Railroads, Land and Iron; A Phase in the Career of Lewis Henry Morgan. Ph.D. Dissertation, Columbia University.

Boyum, Burton H., and Reed, Robert C. 1988. Marquette Mineral District of Michigan with emphasis on Mining History and Geology: Thirty Fourth Annual Institute on Lake Superior Geology, Field Trip Guidebook Volume 2.

Brooks, T.B. 1873. Iron Bearing Rocks of the Upper Peninsula of Michigan. Julius Bien, New York. Michigan Geological Survey Report for 1869-1873. Two Volumes.

Cannon, W.F., 1999, Early Proterozoic Strata of the Marquette Iron Range: Forty-Fifth Annual Institute on Lake Superior Geology, Field Trip Guidebook.

Cannon, William Closing of the Midcontinent rift-A far-field effect of Grenvillian compression, Geology, v.22, p.155-158, February, 1994.

Carter, James L. and Rankin, Ernest H. (editors). 1970. North to Lake Superior, The Journal of Charles W. Penny, 1840 The John M. Longyear Research Library, Marquette MI.

Cleland, Charles E. 1992. Rites of Conquest: The History and Culture of Michigan's Native Americans. Ann Arbor: University of Michigan Press.

Cronon, William. 1983. Changes in the Land: Indians, Colonists, and the Ecology of New England. New York: Hill and Wang.

Cronon, William and White, Richard, Indians in the land; did the Indians have a special, almost noble, affinity with the American environment - or were they despoilers of it? (a conversation between William Cronon and Richard White) American Heritage, Aug-Sept 1986, v.37 
Dunbar, Willis F. 1965. Michigan: A History of the Wolverine State. Grand Rapids, MI: William B. Eerdmans Publishing Company.

Empire Iron Mining Partnership, Palmer, Michigan. 1993. Pamphlet/Information Brochure.

Foster, J.W. 1865. Geology and Metallurgy of the Iron Ore of Lake Superior: Being a Report Addressed to the Board of Directors of the Iron Cliffs Company. Bryant and co. Printers, New York.

Foster, J.W., Whitney, J.D., 1851. Report on the Geology of the Lake Superior Land District, Part II, The Iron Region, Together with the General Geology. Senate Executive Document Number 4. A. Boyd Hamilton, Washington.

Fuller, George N., Editor. 1928. Geological Reports of Douglass Houghton: First State Geologist of Michigan, 1837-1845 The Michigan Historical Commission, Lansing.

Hatcher, Harlan. 1950. A Century of Iron and Men. Indianapolis: Bobbs-Merrill Company, Inc.

Jopling, James E. Ishpeming and It's Early Mines. Manuscript written October 1, 1931, unpublished in the J.M. Longyear Research Library.

Johnston, Thomas A. 1975. Indian Treaties of the Upper Peninsula: Broken Promises and Forgotten Obligations Master of Arts Thesis, History Department at Northern Michigan University.

Kappler, Charles J. (Clerk to the Senate Committee of Indian Affairs). 1904. Indian Affairs, Laws and Treaties, Volume II (treaties) Washington.

LaBerge, Gene L., 1994 Geology of the Lake Superior Region Geoscience Press, Inc. Tucson, Arizona.

Lake Superior Iron Ore Association. 1952. Lake Superior Iron Ores: Mining Directory and Statistical Record of the Lake Superior Iron Ore District of the United States and Canada Second Edition, Published by the author, Cleveland Ohio

Langhorne, William Thomas. 1988. An Investigation of the Spatial, Temporal, and Organizational Processes of the Industrial Frontier: A Case Study From the Upper Peninsula Of Michigan. Michigan State University. Ph.D. Dissertation.

Mather, William Gwinn. 1903. Paper presented at the $9^{\text {th }}$ Annual Meeting of the Lake Superior Mining Institute. 
Merk, Frederick. 1978. History of the Westward Movement. New York: Alfred A. Knopf. p.229-39.

Mid-Peninsula Library Federation. 1883. History of the Upper Peninsula of Michigan: containing a full account of its early settlement, its growth, development, and resources, an extended description of its iron and copper mines. Also, accurate sketches of its counties, cities, towns and villages Western Historical Co., Chicago

Mulligan, William H. jr. (editor and contributor) 1991. Historic Resources of the Iron Range in Marquette Co., Michigan, 1844-1941. Contributors: Alanen, Arnold R., Boyum, Burton H., Klavitter, Terry G., Tremethick, Martin. Marquette, MI: The Economic Development Corp. of the County of Marquette.

Nordstrom, Paul M. 1999. Geologic Field Trip to the Empire Mine. Forty-Fifth Annual Institute on Lake Superior Geology, Field Trip Guidebook.

Peters, Bernard C. (Editor) 1983. Lake Superior Journal: Bela Hubbard's Account of the 1840 Houghton Expedition Northern Michigan University Press, Marquette.

Rominger, C. 1881. Geologic Survey of Michigan. Upper Peninsula, 1878-1880 Volume $I V$. Published by the Authority of the Legislature of Michigan, Under the Direction of the Board of Geologic Survey. Julies Bien, New York.

Sims, P.K. and Carter, L.M.H, editors, 1996 Archean and Proterozoic Geology of the Lake Superior Region, U.S.A., 1993 U.S. Geological Survey Professional Paper 1556, United States Government Printing Office, Washington.

St. Mary's Canal Mineral Land Company. 1864. Reports upon the Value of the Company's Lands Located in the Iron Region of Lake Superior, County of Marquette, State of Michigan.. Wright and Potter, Boston.

Stearns, Forest W. 1997. History of the Lake States Forests: Natural and Human Impacts. In: Vasievich, J. Michael; Webster, Henry H., editors. Lake States Regional Forest Resource Assessment: Technical Papers. Gen. Tech. Rep. NC189. U.S. Department of Agriculture, Forest Service, North Central Forest Experiment Station. St Paul, MN. Located at the Great Lakes Ecological Assessment web site at http://econ.usfs.msu.edu/gla/reports/physical.htm

Swineford, A.P. 1869, The Lake Superior Iron District. History of its Mines and Furnaces Published in Marquette. 
Swineford, A.P. 1876. History and Review of the Copper, Iron, Silver, Slate, and Other Material Interests of the South Shore of Lake Superior. Marquette, (LS.) Michigan, the Mining Journal

Swineford, A.P. 1881. Annual Review of the Iron Mining and Other Industries of the Upper Peninsula For the Year Ending Dec., 1880 Mining Journal

Veatch, J.O. 1928. Michigan Quarterly Bulletin, Michigan State College of Agricultural and Applied Science.

Whitaker, J. Russell. 1931. Negaunee, Michigan; An Urban Center Dominated by Iron Mining. The Bulletin of the Geographical Society of Philadelphia, V.XXIX, August.

Whitney, Gordon G. 1994. From Coastal Wilderness To Fruited Plain: A History of Environmental Change in Temperate North America 1500 to Present. Cambridge University Press, New York.

Williams, Ralph D. 1905, reprinted 1986. The Honorable Peter White: A Biographical Sketch of the Lake Superior Iron Country. Cleveland: Freshwater Press Inc. 